\title{
Caracterización genómico-funcional del flagelo subpolar de Bradyrhizobium diazoefficiens USDA 110
}

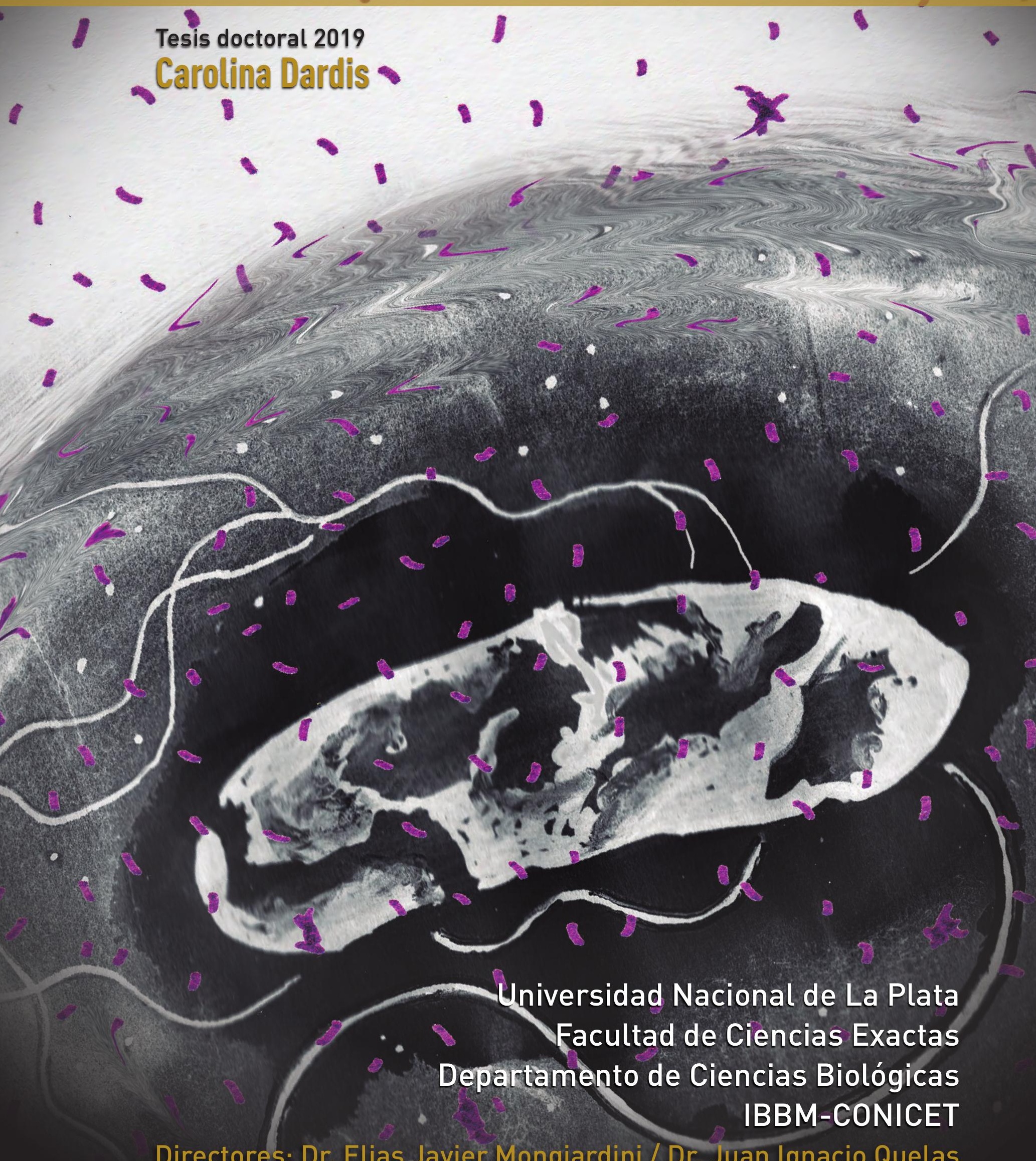





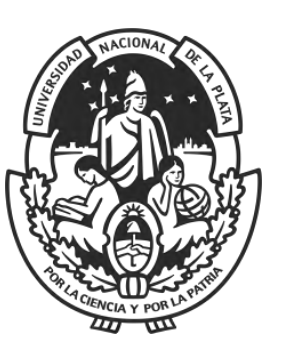

UNIVERSIDAD NACIONAL DE LA PLATA

FACULTAD DE CIENCIAS EXACTAS

DEPARTAMENTO DE CIENCIAS BIOLÓGICAS

Trabajo de Tesis Doctoral

Caracterización genómico-funcional del flagelo subpolar de Bradyrhizobium diazoefficiens USDA 110

Tesista: Lic. Carolina Dardis

Directores:

Dr. Elias Javier Mongiardini

Dr. Juan Ignacio Quelas

Año: 2019 

El presente Trabajo de Tesis para optar al grado de Doctor de la Facultad de Ciencias Exactas ha sido realizado en el Instituto de Biotecnología y Biología Molecular, Departamento de Ciencias Biológicas, Facultad de Ciencias Exactas, UNLP-CCT-La Plata-CONICET, bajo la dirección del Dr. Elías Javier Mongiardini y del Dr. Juan Ignacio Quelas. 

Mi reconocimiento,

A la Facultad de Ciencias Exactas de la Universidad Nacional de la Plata, por ser la institución que me dio el lugar de alumna y de graduada. Por el cariño que le tengo como Institución y como lugar de trabajo.

Al Instituto de Biotecnología y Biología Molecular (IBBM) y al conjunto de gente que lo forma, por brindarme el espacio físico y personal propicio para la realización de este Trabajo de Tesis.

Al Consejo Nacional de Investigación Científica y Tecnológica (CONICET) por haberme otorgado las Becas que significaron el apoyo económico gracias a las cuales pude dedicarme estos años a la realización de este trabajo.

Mi más sincero agradecimiento,

A Aníbal, por brindarme un lugar en su laboratorio y aceptar ser mi director de beca.

A mis directores..

A Elías, gracias por estar al lado mío pasándome todos sus conocimientos de biología molecular, los cuales representan lo más importante que me llevo hoy en día. Por entrenar mi paciencia y darme aliento cuando los mutantes no salían y las complementaciones no complementaban... Por aguantarme sobre todo durante la escritura!!! Muchas gracias.

A Nacho, por escuchar y alentarme a realizar nuevos experimentos, por sus contactos en el extranjero que no dieron su fruto, pero que igualmente los agradezco un montón.

Al resto de los R3ses..

Jota, por compartir los momentos buenos con alegría y los malos con abrazos, eso sí.. siempre con un mate de por medio. Por tratar de hacer de nuestro trabajo un ambiente cálido y ameno.

Peti, por la alegría que te caracteriza y la pasión compartida por el deporte, sobre todo los deportes voladores!!

Pity, por los consejos microbiológicos y por esos budines que te salen tan ricos.

Flor López, por esos eneros y febreros calurosos y agotadores... pero que los mejorabas con unos bizcochitos, facturas o budines.

A los R3sitos, cazadores de focas, hijos de CAGIN o porongueros....

Feliz de haberlos conocido!! Fue hermoso compartir estos años con ustedes..

A Flor, por ese primer año que empezamos el doctorado juntas, siempre dándonos una mano. Incluso años más tarde, compartiendo los mates de la mañana tempranito y los problemas con las real time!!! Gracias por estar siempre dispuesta a ayudar. 
A Vale por su prolijidad y orden para trabajar. Por lo compañera y divertida en las salidas!! lujuuu

A Esteban, alborotado como el sólo... gracias por tus momentos de alegría y por todos los bailes en el pasillo, que siempre me hacían sacar una sonrisa. Quiero que seas mi próxima pareja de salsa, jajaja.

A Caro C., gracias por tu paz y tranquilidad contagiosa. Por compartir los momentos de escritura y papers.

A Gabi, por la compañía y charlas mientras íbamos a comprar comida!!

A Mengu!! Amiga!! Gracias por tu compañía constante en estos largos años, por las mateadas, cervezas, días de playa, de juegos de cartas, de llantos y de festejos. Porque sos una amiga de fierro. Te quiero.

A Juliet por su alegría contagiosa de todos los días, por ser tan transparente y solidaria. A Gonzalo por sus consejos y ayuda constante de biología molecular (incluso desde Alemania).

A los becarios del instituto, por compartir los afteroffice con una cervecita bien helada.

A todos los del instituto que siempre estuvieron ahí dando una mano, ya sea haciendo el aguante cuando se rompía algo, prestando equipos, o dando consejos laborales. Sobre todo a los RPS (a los que siguen, a los que se fueron y a los recién llegados) que nos tenían todos los días ahí firmes en el laboratorio o en el cuartito de becarios. Al personal de apoyo que estuvo siempre a disposición ayudándonos con los medios de cultivos, cajas de tips, ensayos de plantas, etc.

A la salsa y bungee.. que me permitieron mantenerme encarrilada y sentirme plena.. por la gente linda que conocí en esas actividades...

A mis amigos y familia,

A Nico y Maca por todos los momentos compartidos, porque me bancaron siempre...por Nahitan que todavía no pude ir a conocer!!

A mi negro.. Por estos cinco años hermosos.. por siempre mostrarme otra manera de hacer las cosas, con menos preocupaciones y más disfrute.. por calmarme en los momentos de desesperación..por compartir los momentos más lindos y los más feos. Por lo que vendrá.. Te amo.

Gracias al clan Espinosa por incorporarme en su familia, por ser tan graciosos y amorosos conmigo. Una mención especial a Martín por aceptar diseñar la tapa de la Tesis junto con Fran. Muchísimas gracias chicos.

A mis cuñados que son unos genios..Porque me encanta compartir momentos con ustedes!!

A mis hermanas, sostén constante y amoroso..Las quiero mucho.. Gracias por su compañía, consejos y por las tres personitas más lindas que crearon.. Salvi, Cata y 
Fausti... Por el amor incondicional que existe entre nosotros, porque sus sonrisas llenan mi alma...

A mis papás, Mirti y Erni, por apoyarme, dejarme crecer, y criarme con total libertad para elegir mi propio camino. Por lograr que compartir un día en familia sea mi mejor plan para el fin de semana...Porque son los mejores padres y abuelos.. Los quiero con todo mi corazón!!!!

A mi investigadora y poeta favorita, gracias por tu interpretación de mi tema de trabajo en estos años.

Dos niveles coevolucionan, serpentean, se aproximan, se alejan... Comunican su consonancia y disonancia.

Algo en el intercambio sucede...

Hay otras muchas, y entre tantas, Ellas, en reciprocidad, significan, transfieren señales y se introducen en ese otro intersticio.

Allí se aloja y permanece, anida, se aquieta, informa y se transforma. Es acogida e inicia otra nueva experiencia.

Ambas se satisfacen en la apertura. Dejan de ser ellas mismas y en la entrega; en el entretejido de vínculos, algo nuevo sucede. 



\section{Tabla de contenido}

Capítulo I: Introducción ....................................................

I.1 Los Rizobios, la Fijación Biológica de Nitrógeno y su aplicación en la industria

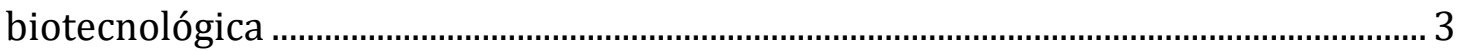

I.1.1 Importancia de la Fijación Biológica de Nitrógeno........................................ 3

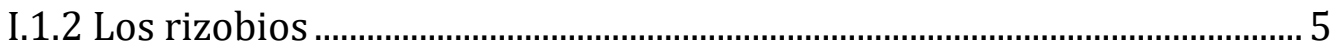

I.1.3 Problemática del uso de inoculantes para soja ............................................... 8

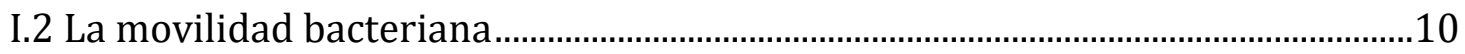

I.2.1 Importancia general en bacterias ...................................................................10

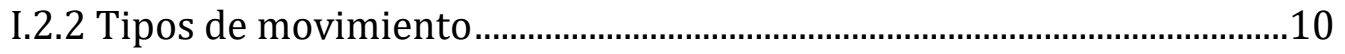

I.3 Movimiento bacteriano mediante flagelos...................................................................12

I.3.1 Descripción general .................................................................................12

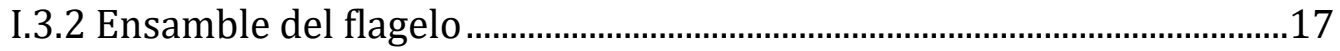

I.3.3 Regulación génica de la síntesis flagelar.................................................20

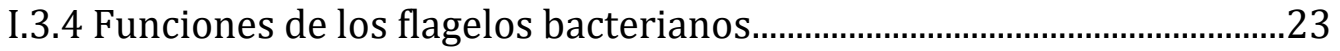

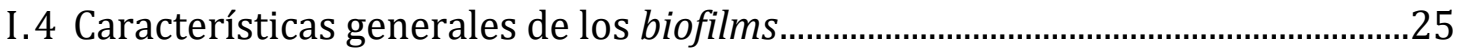

I.5 Regulación mediada por el segundo mensajero c-di-GMP ....................................27

I.5.1 Rol fisiológico del c-di-GMP en el desarrollo y morfogénesis bacteriano

I.5.2 Rol fisiológico del c-di-GMP sobre la movilidad bacteriana y la formación de biofilms .29

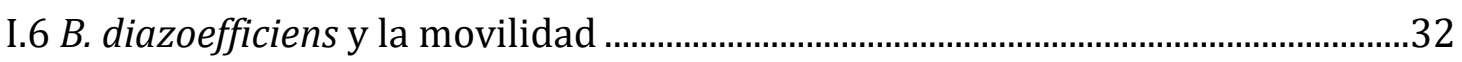

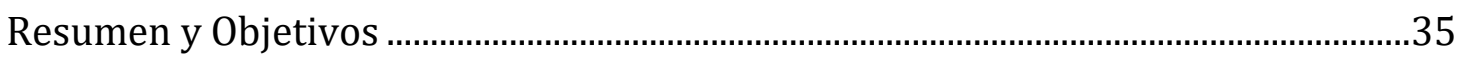

Capítulo II: Materiales y Métodos ..................................... 37

II.1 Herramientas bioinformáticas .............................................................................39

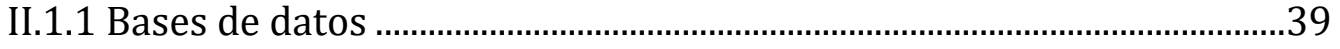

II.1.2 Búsquedas de secuencias homólogas y dominios conservados...........39

II.1.3 Alineamientos y árboles filogenéticos ............................................................39

II.1.4 Modelado de regiones 5'no traducidas.......................................................39

II.2 Cepas y plásmidos utilizados ………................................................................... 40

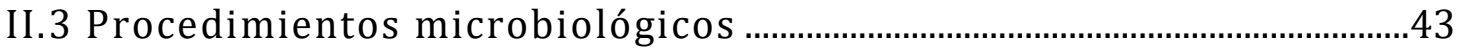

II.3.1 Medios de cultivos para microorganismos.................................................43

II.3.2. Conservación de las bacterias ......................................................................45 
II.3.3 Cultivos bacterianos y preparación de inóculos .45

II.3.4 Estimación de la biomasa y recuento en placa . .46

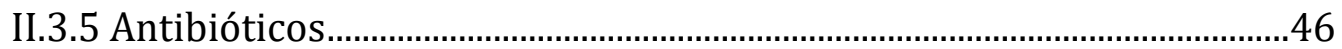

II.3.6 Preparación de células electrocompetentes de E. coli ...........................46

II.3.7 Electrotransformación de células electrocompetentes de E. coli .......47

II.3.8 Conjugaciones biparentales …................................................................... 47

II.3.9 Ensayos de natación en agar semisólido ......................................................47

II.3.10 Observación y cuantificación de exopolisacáridos (EPS) ....................48

II.3.10.b Cuantificación de EPS mediante el método de Antrona ....................48

II.3.11 Ensayos de adhesión a tubos de vidrio ........................................................48

II.3.12 Ensayos de sensibilidad a SDS ...................................................................49

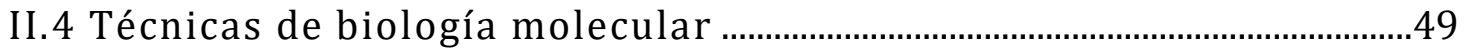

II.4.1 Preparación de ADN plasmídico..................................................................49

II.4.2 Extracción de ADN total...........................................................................49

II.4.3 Extracción de ARN total..............................................................................50

II.4.4 Transcripción reversa, RT-PCR y qRT-PCR …….......................................50

II.4.5 Reacción en Cadena de la Polimerasa (PCR) ...............................................52

II.4.6 Tratamientos enzimáticos del ADN............................................................54

II.4.7 Electroforesis en geles de agarosa...........................................................54

II.4.8 Revelado de geles y fotografía...................................................................54

II.4.9 Estrategias de clonado y mutagénesis ......................................................55

II.4.10 Secuenciación de ADN plasmídico y/o fragmentos de ADN ..............57

II.5 Manipulación de proteínas …………...................................................................57

II.5.1 Obtención de flagelinas extracelulares ....................................................57

II.5.2 Análisis de proteínas mediante geles de poliacrilamida discontinuos en condiciones desnaturalizantes (SDS-PAGE) ........................................................58

II.5.3 Tinción de las proteínas.............................................................................58

II.5.4 Identificación de los polipéptidos de flagelinas mediante

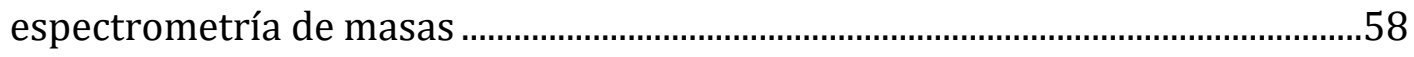

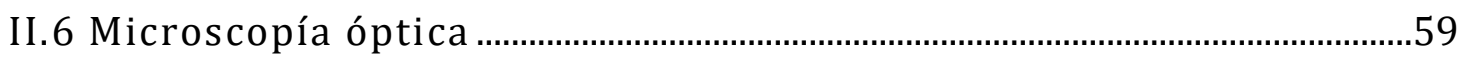

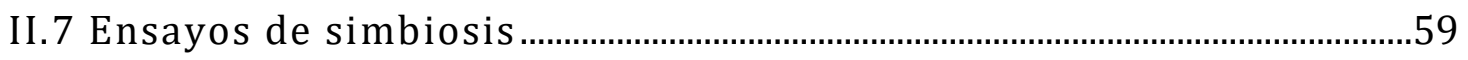

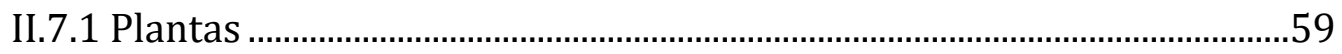

II.7.2 Medio de cultivo de plantas........................................................................59

II.7.3 Esterilización superficial y germinación de las semillas.........................60

II.7.4 Ensayo de nodulación.................................................................................60 
Capítulo III: Caracterización genómica del sistema flagelar subpolar de

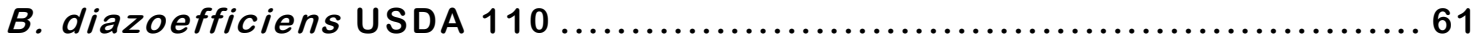

III.1 Introducción ..................................................................................................................63

III.2 Anotación funcional de los posibles clusters relacionados al sistema del flagelo subpolar

III.3 Búsqueda de posibles genes regulatorios de la síntesis del sistema del flagelo subpolar

III.4 Genes parálogos que codificarían componentes estructurales del flagelo subpolar en $B$. diazoefficiens

III.4.1 Análisis bioinformático de los componentes estructurales duplicados en B. diazoefficiens.

III.4.2 Análisis de genes del motor: construcción de un mutante en motB (bll1510)

III.4.3 Análisis de genes del gancho: construcción de un mutante en blr3699. 79

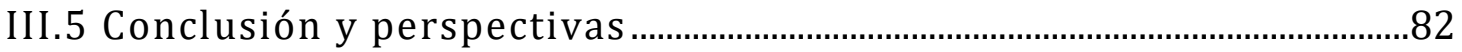

III. 6 Anexo .84

Capítulo IV: CtrA y su función como regulador del flagelo subpolar de $B$.

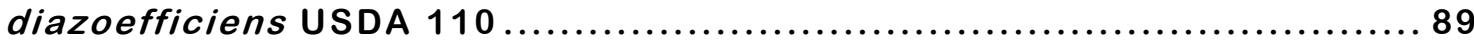

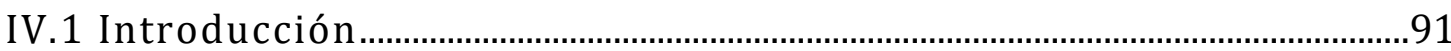

IV.2 Análisis bioinformático de los componentes que integran la cascada de señalización de CtrA en B. diazoefficiens .........................................94

IV.3 Obtención de una cepa mutante de B. diazoefficiens en ctrA .............99

IV.4 Obtención de una cepa mutante de B. diazoefficiens en la posible

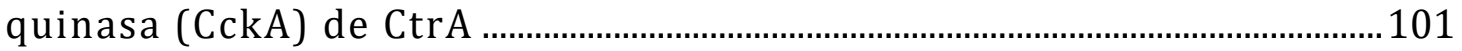

IV.5 Efecto de la sobreexpresión de CtrA sobre la síntesis flagelar ......102

IV.5.1 Caracterización fenotípica de la cepa Bd-pFAJ::ctrA ............................104

IV.6 Conclusión y Perspectivas …………………........................................................ 107

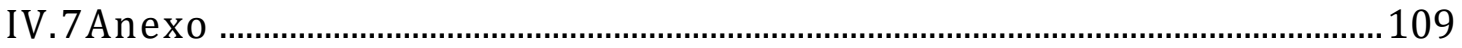

Capítulo V: Caracterización de los reguladores de clase II (FlbD-FliX) de la cascada de síntesis del flagelo subpolar de $B$. diazoefficiens USDA

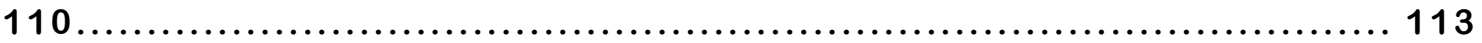

V.1 Introducción

115

V.2 Análisis bioinformático de los posibles reguladores de clase II de la cascada de síntesis del flagelo subpolar en B. diazoefficiens......................116

V.3 Construcción de mutantes de B. diazoefficiens en flbD y fliX ............118

V.4 Caracterización fenotípica de los mutantes $B$. diazoefficiens $\triangle$ flbD y

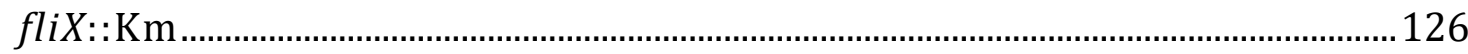

V.4.1 Efecto de la mutación de $f l b D$ y fliX sobre la síntesis flagelar y la capacidad de natación. 
V.4.2 Caracterización de los genes flagelares regulados por FlbD y FliX.131

V.4.3 Mecanismos de acción de FlbD.

V.4.4 Otros fenotipos asociados con los reguladores clase II FlbD y FliX 138

V.4.5 Efecto sobre la producción de EPS y la formación de biofilms.

V.4.6 Efecto de la mutación de los reguladores de clase II sobre el proceso simbiótico.

V.5 Conclusión y perspectivas

Capítulo VI: Caracterización de posibles reguladores clase III (FlaFFIbT) de la cascada de síntesis del flagelo subpolar de B. diazoefficiens

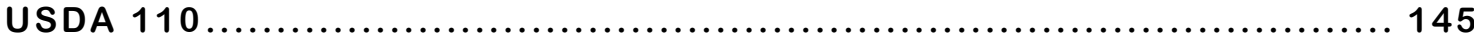

VI.1 Introducción 147

VI.2 Análisis bioinformático de FlaF y FlbT asociadas al flagelo subpolar de $B$. diazoefficiens ....................................................................................149

VI.3 Obtención de mutantes de B. diazoefficiens en flaF $F_{S}$ y flb $T_{S}$...............150

VI.3.1 Caracterización de los mutantes de B. diazoefficiens en fla $F_{S}$ y $f l b T_{S}$ 153

VI.3.2 Efecto de la mutación de $\mathrm{flbT}_{S}$ y $\mathrm{flaF}_{S}$ sobre los niveles de transcripción de los genes de las flagelinas subpolares 154

VI.3.3 Efecto de la mutación de $f l b T_{S}$ y $f l a F_{S}$ sobre la movilidad bacteriana 156

VI.3.4 Composición del filamento del mutante de B. diazoefficiens en flbT::Km. 158

VI.3.5 Posible rol de FlbTs en la regulación de otros transcriptos independientes de los sistemas flagelares. 160

VI.4 Conclusión y perspectivas 163

VI.5 Anexo 165

Capítulo VII: Efectos del C-di-GMP sobre los dos sistemas flagelares de

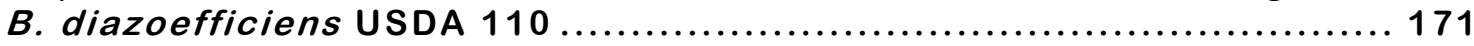

VII.1 Introducción 173

VII.1.2 Análisis bioinformático de proteínas relacionadas con la vía de señalización a través de c-di-GMP en B. diazoefficiens USDA 110.......................174

VII.2 Expresión heteróloga de ciclasas ....................................................................177

VII.2.1 Construcción de cepas que expresan PleD* y TpbB..........................177

VII.2.2 Efecto de la expresión de ciclasas heterólogas sobre el crecimiento en $B$. diazoefficiens 179

VII.2.3 Efecto de la expresión de ciclasas heterólogas sobre la movilidad en B. diazoefficiens 181

VII.2.4 Efecto de la expresión de ciclasas heterólogas sobre la producción de EPS y la formación de biofilms en B. diazoefficiens 183 
VII.2.5 Efecto del c-di-GMP sobre los reguladores del sistema flagelar subpolar 184

VII.3 Caracterización de una DGC y PDE de B. diazoefficiens. 186

VII.4 Conclusión y perspectivas 188

VII.5 Anexo 190

Capítulo VIII: Discusión 191

Bibliografía 201 


\section{Índice de Figuras}

\section{Capítulo I}

Figura I.1 - Proceso de conversión de Nitrógeno mediado por bacterias y arqueobacterias.

Figura I.2 - Modelo esquemático de la formación y desarrollo de los nódulos de 7

Figura I.3 - Tipos de movimiento bacterianos

Figura I.4 - Patrones de flagelación en diversas especies bacterianas visualizadas a través de microscopía electrónica................................................................................................................. 14

Figura I.5 - Componentes del flagelo bacteriano. ……................................................................... 15

Figura I.6 - Sistema de secreción de tipo III asociado al flagelo. .................................................. 19

Figura I.7 - Esquema regulatorio de la síntesis flagelar............................................................ 21

Figura I.8 - Etapas de la formación de biofilms......................................................................... 26

Figura I.9 - Efecto del c-di-GMP durante la formación de biofilms .............................................. 30

Figura I.10 - Micrografía electrónica de transmisión de B. diazoefficiens USDA 110 crecida

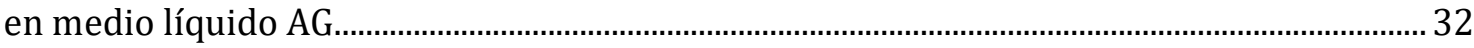

Figura I.11 - Perfil de flagelinas de B. diazoefficiens en distintas condiciones de cultivo (A) y ensayo de movilidad en agar semisólido(B).

\section{Capítulo II}

Figura II.1 Estrategia de clonado descripta por Sukdeo y Charles (2003)................................. 55

Figura II.2 - Estrategia de mutagénesis por inserción de Km........................................................ 56

Figura II.3 - Estrategia de mutagénesis “limpia”............................................................................. 57

\section{Capítulo III}

Figura III.1 - Esquema del cromosoma de B. diazoefficiens USDA 110. 63

Figura III.2 - Organización genómica de los clusters que contienen genes flagelares estructurales y regulatorios que podrían formar parte del sistema del flagelo subpolar de B. diazoefficiens.

Figura III.3 - Lecturas de secuenciamiento de cDNA de los genes parálogos del motor y el gancho de B. diazoefficiens.

Figura III.4 - Arbol filogenético construido con las proteínas MotAB/PomAB de $B$. diazoefficiens USDA 110 y proteínas Mot/Pom de otras especies bacterianas con función conocida.

Figura III.5 - Mapa esquemático del gen bll1510 y genes vecinos (cluster 1) que muestra el diseño utilizado para su mutagénesis. 
Figura III.6 - Esquema del clonado y selección de la cepa mutante de B. diazoefficiens $\Delta m o t B_{1}$

Figura III.7 - Perfil de flagelinas (A) y ensayos de movilidad en agar semisólido (B) de las cepas de $B$. diazoefficiens mutantes en $\operatorname{mot} B_{1}$.

Figura III.8 - Mapa esquemático del gen blr3699 y genes vecinos (cluster 3) que muestra el diseño utilizado para su mutagénesis. 80

Figura III.9 - Esquema del clonado y selección de la cepa mutante de B. diazoefficiens $f l g D_{3}:: \mathrm{Km}$

Figura III.10 - Perfil de flagelinas (A) y ensayos de movilidad en agar semisólido (B) de las cepas de $B$. diazoefficiens mutantes en flg $_{3}$. 82

Figura AIII.1 - Alineamiento múltiple de proteínas parálogas del motor: MotAB/PomAB.

84

Figura AIII.2 - Alineamientos múltiple de proteínas parálogas del gancho: FlgDEKL..........86

Figura AIII.3 - Árboles filogenéticos extraídos de PhylomeDB de proteínas del gancho del cluster $3\left(\mathrm{FlgDEKL}_{3}\right)$...

\section{Capítulo IV}

Figura IV.1 - Cascada regulatoria de la proteína CtrA.........................................................................93

Figura IV.2 - Alineamiento de CtrA de C. crescentus y B. diazoefficiens..................................... 94

Figura IV.3 - Arbol filogenético construido con la proteína CtrA presente en Rhizobiales

Figura IV.4 - Alineamiento de regiones promotoras de genes del flagelo subpolar en $B$. diazoefficiens USDA 110 que contienen la secuencia TTAACCAT. 98

Figura IV.5 - Mapa esquemático del gen ctrA y genes vecinos (cluster 2) que muestra el diseño utilizado para su mutagénesis. 99

Figura IV.6 - Esquema del clonado para la obtención de la cepa mutante de B. diazoefficiens ctrA::Km 100

Figura IV.7 - Mapa esquemático del gen cckA (bll5808) y genes vecinos (cluster 5) que muestra el diseño utilizado para su mutagénesis. 101

Figura IV.8 - Esquema del clonado para la obtención de la cepa mutante de B. diazoefficiens cckA::Km. 103

Figura IV.9 - Esquema del clonado y selección de la cepa que sobreexpresa CtrA (BdpFAJ::ctrA) 104

Figura IV.10 - Cinética de crecimiento de la cepa $B d$-pFAJ::ctrA. 105

Figura IV.11 -Perfil de flagelinas (A) y ensayos de movilidad en agar semisólido (B) de la cepa de B. diazoefficiens que sobreexpresa $c t r A$. 106 
Figura IV.12 - Niveles de expresión de los transcriptos de los posibles reguladores flagelares en la cepa que sobreexpresa ctrA. 107

Figura AIV.1 - Alineamientos de CckA/PleC/DivJ presentes en C. crescentus y $B$. diazoefficiens.

\section{Capítulo V}

Figura V.1 - Alineamiento de FlbD de C. crescentus y B. diazoefficiens USDA 110. 117

Figura V.2 - Alineamiento de FliX de C. crescentus y B. diazoefficiens USDA 110.

Figura V.3 - Alineamiento de regiones promotoras de genes del flagelo subpolar de $B$. diazoefficiens USDA 110 que contienen secuencias ftr putativas. 118

Figura V.4 - Mapa esquemático del gen $f l b D$ (blr7003) y genes vecinos (cluster 6) que muestra el diseño utilizado para su mutagénesis.

Figura V.5 - Mapa esquemático del gen fliX (bll5837) y genes vecinos (cluster 5) que muestra el diseño utilizado para su mutagénesis .120

Figura V.6 - Esquema del clonado y selección de la cepa mutante de B. diazoefficiens $\Delta$ flbD.

Figura V.7 - Esquema del clonado y selección de las cepas WT y $\Delta f l b D$ llevando pB3::flbD.

Figura V.8 - Esquema del clonado y selección de la cepa mutante de B. diazoefficiens fliX::Km. 125

Figura V.9 - Esquema del clonado y selección de las cepas WT y fliX::Km llevando pFAJ::fliX. 126

Figura V.10 - Cinética de crecimiento y morfología celular de las cepas de B. diazoefficiens mutantes en $f l b D$ y fliX.

Figura V.11 - Perfil de flagelinas (A) y ensayos de movilidad en agar semisólido (B, C y D) de las cepas de $B$. diazoefficiens mutantes en los reguladores de clase II. 128

Figura V.12 - Perfil de flagelinas (A) y ensayos de movilidad en agar semisólido (B) de las cepas de $B$. diazoefficiens mutantes en $f l b D$ y fliX complementadas. 129

Figura V.13 - Expresión de $f l b D$ en la cepa mutante $\Delta f l b D$-pB3:: $f l b D$ 130

Figura V.14 - Perfil de flagelinas (A) y ensayos de movilidad en agar semisólido (B) de las cepas de B. diazoefficiens flbD (flbD::Km) y mutante complementada (flbD::Km-pB3::flbD).

Figura V.15 - Perfil de flagelinas (A) y ensayos de movilidad en agar semisólido (B) de las cepas de $B$. diazoefficiens que sobreexpresan $f l b D$ y fliX 131

Figura V.16 - Mapa esquemático del gen blr7003 y genes vecinos (cluster 6) que muestra el diseño utilizado para la mutagénesis puntual para obtener la cepa $f l b D-D x A$. 134 
Figura V.17 - Esquema del clonado y selección de la cepa mutante puntual de $B$. diazoefficiens flbDDxA

Figura V.18 - Perfil de flagelinas (A) y ensayos de movilidad en agar semisólido (B) de la cepa de $B$. diazoefficiens mutante puntual $f l b D D x A$. 137

Figura V.19 - Perfil de flagelinas (A) y ensayos de expresión (B) de las cepas de $B$. diazoefficiens mutantes que codifican factores $\sigma^{54}$ 138

Figura V.20 - Niveles de expresión del transcripto del regulador maestro del flagelo lateral (lafR) en los mutantes de B. diazoefficiens en los reguladores de clase II.

Figura V.21 - Producción de EPS en los mutantes en los reguladores clase II. 140

Figura V.22 - Adhesión a tubos de vidrio de los mutantes de B. diazoefficiens en los reguladores de clase II

Figura V.23 - Adhesión a tubos de vidrio de los mutantes de B. diazoefficiens estructurales en las flagelinas de los dos sistemas flagelares. 141

\section{Capítulo VI}

Figura VI.1 - Árboles filogenéticos de FlaF (A) y FlbT (B) y homólogos con función conocida. 150

Figura VI.2 - Mapa esquemático del gen flaF y genes vecinos (cluster 5) que muestra el diseño utilizado para su mutagénesis en B. diazoefficiens USDA 110. 151

Figura VI. 3 - Mapa esquemático del gen flbT (bll5847) y genes vecinos (cluster 5) que muestra el diseño utilizado para su mutagénesis en B. diazoefficiens USDA 110. 152

Figura VI.4 - Esquema del clonado y selección de la cepa mutante de B. diazoefficiens $\Delta$ flaF

Figura VI.5 - Cinética de crecimiento (A) y perfil de flagelinas de las cepas de $B$. diazoefficiens mutantes en flaF y flbT.

Figura VI.6 -Perfil de flagelinas (A) y ensayos de movilidad en agar semisólido (B) de las cepas mutantes de $B$. diazoefficiens en flaF y flbT. 157

Figura VI.7 - Ensayo de movilidad en agar semisólido de mutantes de B. diazoefficiens carentes de flagelinas laterales y de los genes flaF y flbT. 157

Figura VI.8 - Producción de EPS en los mutantes de B. diazoefficiens en flaF y flbT. .161

Figura IV.9 - Alineamientos de las regiones $5^{\prime}$ no traducidas (5'UTR) de los genes que codifican las flagelinas subpolares.

162

Figura VI.10 - Halos de inhibición de crecimiento en placas de Petri utilizando discos de papel embebidos con SDS. 163

Figura AVI.1 -Alineamiento de las secuencias nucleotídicas de las cuatro flagelinas subpolares de la secuencia codificante y la región 5'no codificante. 167 
Figura AVI.2 - Predicción de estructura secundaria de las regiones 5’UTR de los genes que codifican flagelinas subpolares

Figura AVI.3 - Organización genómica de los genes que poseen la secuencia consenso CCAGAAGGGTAA

\section{Capítulo VII}

Figura VII.1 - Esquema del clonado y selección de la cepa de B. diazoefficiens que expresa tpbB de $P$. aeruginosa. 178

Figura VII.2 - Esquema del clonado y selección de la cepa de B. diazoefficiens que expresa ple $^{*}$ de $C$. crescentus.

Figura VII.3 - Cinética de crecimiento de la cepa de B. diazoefficiens que expresa tpbB...

Figura VII.4 - Cinética de crecimiento de la cepa de B. diazoefficiens que expresa pleD*.

Figura VII.5 - Perfil de flagelinas (A) y ensayos de movilidad en agar semisólido (B) de la cepa de $B$. diazoefficiens que expresa tpbB. 182

Figura VII.6 - Perfil de flagelinas (A) y ensayos de movilidad en agar semisólido (B) de la cepa de $B$. diazoefficiens que expresa $p l e D^{*}$. 183

Figura VII.7 - Producción de EPS de la cepa de B. diazoefficiens que expresa pleD $^{*}$............184

Figura VII.8 - Adhesión a tubos de vidrio de la cepa B. diazoefficiens que expresa pleD*186

Figura VII.9 - Perfil de flagelinas (A) y ensayos de movilidad en agar semisólido (B) de las cepas de B. diazoefficiens mutantes en los genes bll1502 y bll1500. 187

Figura VII.10 -Ensayo de adhesión a tubos de vidrio de las cepas de B. diazoefficiens mutantes en bll1502 y bll1500.

Figura AVII.1 - Alineamiento deBll1502 de B. diazoefficiens y BpdA de B. melitensis.........190

\section{Capítulo VIII}

Figura VIII.1 - Modelo regulatorio de la síntesis del flagelo subpolar en B. diazoefficiens USDA 110 


\section{Índice de Tablas}

\section{Capítulo II}

Tabla II.1 - Cepas utilizadas en este trabajo. 40

Tabla II.2 - Plásmidos utilizados en este trabajo. 42

Tabla II.3 - Concentraciones de antibióticos utilizadas en este trabajo. 46

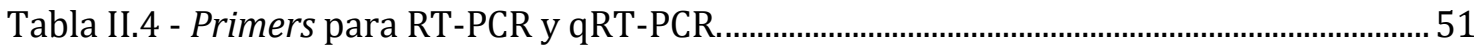

Tabla II.5 - Primers para mutagénesis utilizados en este trabajo. 53

\section{Capítulo III}

Tabla III.1 - Listado de genes en los seis clusters que podrían ser parte del sistema del flagelo subpolar de B. diazoefficiens.

Tabla III.2 - Predicción de dominios de las proteínas MotAB/PomAB del motor de $B$. diazoefficiens (codificadas en tres genes parálogos) 72

Tabla III.3 - Predicción de dominios de las proteínas FlgE y FlgD del gancho flagelar de B. diazoefficiens (codificadas en tres genes parálogos).

Tabla III.4 - Predicción de dominios de las proteínas FlgK y FlgL del gancho flagelar de B. diazoefficiens (codificadas en tres genes parálogos).

\section{Capítulo IV}

Tabla IV.1 - Predicción de dominios de las proteínas involucradas en la vía de señalización de CtrA en B. diazoefficiens y C. crescentus.

Tabla AIV.1 - Tabla con los genes que poseen la secuencia TTAACCAT en su región promotora encontrada a través del servidor MEMEsuite.

\section{Capítulo V}

Tabla V.1 Niveles de expresión de ARNm en los reguladores de clase II.

Tabla V.2 - Ensayo de nodulación de plantas de soja de los mutantes en los reguladores de clase II.

\section{Capítulo VI}

Tabla VI.1 - Porcentaje de similitud de secuencia nucleotídica y aminoacídica entre las cuatro flagelinas subpolares.

Tabla VI.2 - Medidas de qRT-PCR de los cuatro genes que codifican flagelinas subpolares sobre los mutantes en los reguladores de clase III de B. diazoefficiens.

Tabla VI.3 - Secuencias de péptidos únicos para cada flagelina.

Tabla VI.4 - Cantidades relativas de flagelinas en el filamento subpolar en la cepa WT y flbT::Km. 


\section{Capítulo VII}

Tabla VII.1 - Grado de conservación de proteínas de la vía de señalización de c-diGMP de Bradyrhizobium y en otras especies de rizobios.

TablaVII.2 - Niveles de ARN mensajeros de genes del flagelo subpolar en la cepa $B$. diazoefficiens $\mathrm{pFAJ}::$ pleD* 
Capítulo I: Introducción 



\section{I.1 Los Rizobios, la Fijación Biológica de Nitrógeno y su aplicación en la industria biotecnológica}

\section{I.1.1 Importancia de la Fijación Biológica de Nitrógeno}

El Nitrógeno (N) es uno de los cinco elementos más abundante en el sistema solar y es esencial para la síntesis de dos biopolímeros importantes para la vida como son los ácidos nucleicos y las proteínas. A pesar de ser un elemento abundante en la Tierra, la gran mayoría se encuentra en la atmósfera como dinitrógeno $\left(\mathrm{N}_{2}\right)$. En cambio, los nitritos $\left(\mathrm{NO}_{3}{ }^{-}\right)$y el amonio $\left(\mathrm{NH}_{4}{ }^{+}\right)$, que son los iones más requeridos en los ecosistemas terrestres y marinos, se encuentran en cantidades limitantes, en especial en los agroecosistemas (Canfield et al., 2010).

El $\mathrm{N}_{2}$ es considerado una "molécula inerte" debido a la gran energía que se requiere para romper el triple enlace que une ambos átomos de nitrógeno $(\mathrm{N} \equiv \mathrm{N})$. En la naturaleza, uno de los procesos fundamentales que logra reducir $\mathrm{N}_{2}$ a $_{\mathrm{NH}_{4}}^{+}$es la fijación biológica de nitrógeno (FBN). Este proceso es llevado a cabo solo por organismos procarióticos (tanto bacterias como arqueobacterias) ya sea en vida libre como en simbiosis con plantas. Para que ocurra este proceso, resulta necesaria la acción de un complejo enzimático llamado nitrogenasa, que utiliza la energía resultante de la hidrólisis de 16 moléculas de ATP para reducir cada molécula de $\mathrm{N}_{2}$ a $\mathrm{NH}_{4}{ }^{+}$(Halbleib y Ludden, 2000).

A pesar de que la nitrogenasa está ampliamente distribuida en distintos linajes de procariotas, muchos de ellos no son capaces de fijar $\mathrm{N}_{2}$ y utilizan el $\mathrm{NH}_{4}{ }^{+}$directamente del ambiente o reducen $\mathrm{NO}_{3}{ }^{-}$a $\mathrm{NH}_{4}{ }^{+}$. A su vez, el $\mathrm{NH}_{4}{ }^{+}$puede retornar al ambiente como $\mathrm{NO}_{3}{ }^{-}$(en presencia de $\mathrm{O}_{2}$ ) a través del proceso denominado nitrificación, el cual es realizado gracias a la acción de bacterias o arqueobacterias que poseen la enzima amonio monooxigenasa (Canfield et al., 2010). En ausencia de oxígeno, algunos microorganismos pueden usar el $\mathrm{NO}_{3}{ }^{-}$como último aceptor de electrones en la cadena respiratoria y transformarlo en $\mathrm{NH}_{4}{ }^{+}$(reducción no asimilatoria de nitrato a amonio o DNRA) o en $\mathrm{N}_{2}$ (desnitrificación) (Demanèche et al., 2009). Además, el $\mathrm{N}_{2}$ puede volver a la atmósfera a través de la oxidación de $\mathrm{NH}_{4}{ }^{+}$(oxidación anaeróbica de amonio) (Figura I.1). 


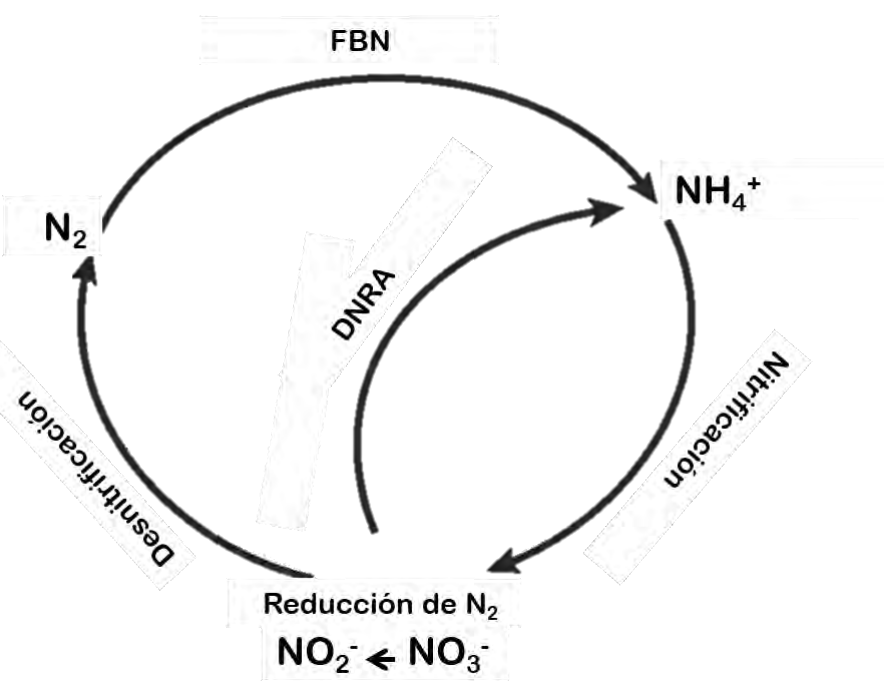

Figura 1.1 - Proceso de conversión de Nitrógeno mediada por bacterias y arqueobacterias. El $\mathrm{N}_{2}$ atmosférico es reducido a $\mathrm{NH}_{4}{ }^{+}$mediante la Fijación Biológica de Nitrógeno (FBN). A su vez, el $\mathrm{NH}_{4}{ }^{+}$puede ser oxidado a través del proceso de nitrificación generando $\mathrm{NO}_{3}{ }^{-}$. Este compuesto puede ser transformado a $\mathrm{NH}_{4}{ }^{+}$a través del proceso de reducción no asimilatoria de nitrato a amonio (DNRA) o a $\mathrm{N}_{2}$ mediante el proceso de desnitrificación. Extraído y modificado de Kellogg y col. (2016).

A partir del siglo $\mathrm{XX}$, el ciclo del nitrógeno ha sido perturbado por el hombre mediante varias prácticas, como por ejemplo el uso de fertilizantes biológicos para aumentar los rendimientos de los cultivos y la producción industrial de $\mathrm{NH}_{4}{ }^{+}$a partir de $\mathrm{N}_{2}$ (mediante el proceso Haber-Bosch).

Uno de los principales problemas del uso de fertilizantes nitrogenados reside en que solo el $40 \%$ del $\mathrm{NH}_{4}{ }^{+}$aplicado es transformado a biomasa. La parte restante drena en el suelo quedando lejos del alcance de las raíces o retorna a la atmósfera mediante el proceso de desnitrificación (Canfield et al., 2010). El aumento en este proceso, dado por un exceso localizado de $\mathrm{NH}_{4}{ }^{+}$, trae aparejado otros problemas en los suelos y el agua como son la hipoxia (por el consumo de oxígeno durante la nitrificación), la eutrofización de aguas superficiales y subterráneas, y la producción de intermediarios de nitrógeno como el $\mathrm{N}_{2} \mathrm{O}$, que es un producto muy nocivo para la capa de ozono y contribuye al calentamiento global (Ravishankara et al., 2009).

Para evitar que se continúe agravando esta situación debido al uso de fertilizantes nitrogenados, Canfield y colaboradores (2010) propusieron la implementación de varias estrategias como por ejemplo (i) rotación sistemática de cultivos para evitar la depleción de nitrógeno de los suelos, (ii) optimización de la periodicidad y cantidad de fertilizante que se aplica actualmente, (iii) obtención de variedades de plantas cultivables genéticamente modificadas que mejoren la eficiencia del uso del nitrógeno, (iv) utilización de cultivos que produzcan inhibidores del proceso de nitrificación, (v) optimización y desarrollo de cultivos capaces de establecer relaciones simbióticas con bacterias fijadoras de nitrógeno.

Este último abordaje de optimización de relaciones simbióticas fijadoras de nitrógeno representa la principal meta de nuestro laboratorio. En las secciones 
siguientes serán abordadas las problemáticas asociadas a la eficiencia simbiótica, particularmente del par Bradyrhizobium diazoefficiens-soja, enfocando el estudio sobre esta especie de bacteria fijadora de nitrógeno.

\section{I.1.2 Los rizobios}

Dentro de las bacterias fijadoras de nitrógeno encontramos a los rizobios, llamados así dada su capacidad de colonizar e infectar las raíces de las plantas pertenecientes a la familia de las leguminosas. Dentro de los rizobios, encontramos bacterias pertenecientes al género Bradyrhizobium, Azorhizobium, Methylobacterium, Mesorhizobium, Rhizobium, Sinorhizobium (todas ellas $\alpha$-Proteobacterias) y Wautersia y Burkholderia (B-Proteobacterias) (Lloret y Martínez-Romero, 2005). Estos rizobios comparten ciertas características, son bacilos Gram-negativos, no esporulantes, aeróbicos y/o microaeróbicos (Jordan, 1984).

Los estilos de vida de los rizobios son muy diferentes ya que pueden encontrarse en vida libre en el suelo (ya sea en estado planctónico o en estado sésil) o como endosimbiontes fijadores de nitrógeno dentro de los nódulos que se forman en las raíces de las plantas hospedantes. Dentro de estos órganos nuevos desarrollados por las plantas, los rizobios sufren una diferenciación (producto de un programa genético complejo) transformándose a en bacteroides (Oldroyd et al., 2011). Los bacteroides son capaces de transformar $\mathrm{N}_{2}$ a $\mathrm{NH}_{4}{ }^{+}$(a través del complejo nitrogenasa) mediante la FBN, e inmediatamente la planta lo convierte en glutamina para poder asimilarlo. A cambio del nitrógeno otorgado, los bacteroides toman de la planta ácidos dicarboxílicos, los cuales utilizan como fuente de carbono y energía (Prell y Poole, 2006).

\section{Simbiosis Rizobio-leguminosa}

Para iniciar el proceso de simbiosis es necesario que ocurra un intercambio de señales entre la planta hospedante y el rizobio, previo a la infección (Jiménez-Guerrero et al., 2017). Este evento comienza con la liberación de señales químicas provenientes de ambos organismos. En un primer momento, la planta libera flavonoides (metabolitos fenilpropanoides) a través de los exudados radicales. Estas moléculas actúan como inhibidores de crecimiento de bacterias y hongos patógenos, sin embargo, algunas de ellas son capaces de promover el crecimiento y/o actuar como moléculas quimioatrayentes de los rizobios del suelo (Cooper, 2007). Por su parte los rizobios son capaces de reconocer los flavonoides a través de un factor transcripcional llamado NodD, a través del cual se induce la expresión de genes necesarios para la síntesis de un lipoquitooligosacárido denominado Factor Nod (Downie, 2010). Este compuesto es reconocido por la planta y su acción es importante para el reconocimiento y la especificidad del proceso simbiótico (Downie, 2010). Además, el 
Factor Nod interviene en el proceso de señalización inicial que desencadena la formación del primordio de nódulo (Ferguson et al., 2010).

La organogénesis del nódulo involucra varias etapas (Figura I.2). En primera instancia, el rizobio encuentra la raíz y es capaz de adherirse a la superficie de la misma. La infección solo puede darse en una región acotada de la raíz conocida como la región de pelos radicales emergentes (Bhuvaneswari et al., 1980). Pasadas 6-8 hs. luego de la adhesión, se produce la deformación de los pelos radicales emergentes generando un enrulamiento de los mismos (Ferguson et al., 2010; Patriarca et al., 2004). Luego se produce la degradación del mucílago y la pared celular de la zona radical, lo que le permite al rizobio infectar la raíz formando un hilo de infección (Gage, 2004). Este hilo de infección consiste en una estructura tubular en las células de epidermis de la planta, donde la bacteria es capaz de proliferar y prolongar esta estructura hasta alcanzar las células corticales. En cada hilo de infección sólo una célula -o a lo sumo dos- penetran en esta estructura (infección clonal). Luego, se dividen completando el avance a través del hilo de infección y logran alcanzar el nódulo en formación. Los rizobios también pueden infectar las raíces a través de alguna rotura en los pelos radicales (crack entry) e invadir las células corticales sin la necesidad de formar un hilo de infección (Oldroyd y Downie, 2008).

Paralelamente a la formación del hilo de infección, las células corticales de la planta comienzan a dividirse y se forma el primordio de nódulo. Existen dos tipos diferentes de nódulos denominados determinados e indeterminados (Popp y Ott, 2011). El programa de formación y diferenciación de cada uno depende de la leguminosa (Limpens et al., 2005). La principal diferencia entre ellos es que los nódulos determinados se forman en la corteza externa o media de la raíz y tienen forma esférica, mientras que los nódulos indeterminados lo hacen en la corteza interna y presentan meristema persistente, por lo que resultan ovoides (Ferguson et al., 2010).

Durante el desarrollo del nódulo maduro, el rizobio es liberado del hilo de infección por endocitosis quedando recubierto de la membrana plasmática del huésped formándose lo que se conoce como simbiosoma. La bacteria continúa dividiéndose dentro del huésped para luego diferenciarse a bacteroide. Para que ocurra esta diferenciación se requieren numerosos cambios a nivel transcripcional que le permiten a los bacteroides vivir dentro de las células de las plantas y adaptar su metabolismo para ser capaces de fijar $\mathrm{N}_{2}$ (en conjunción con una baja presión parcial de $\mathrm{O}_{2}$ en los nódulos gracias a la presencia de leg-hemoglobina). Los bacteroides son células más alargadas, con baja tasa de crecimiento y no poseen flagelos (Kondorosi et al., 2013). 


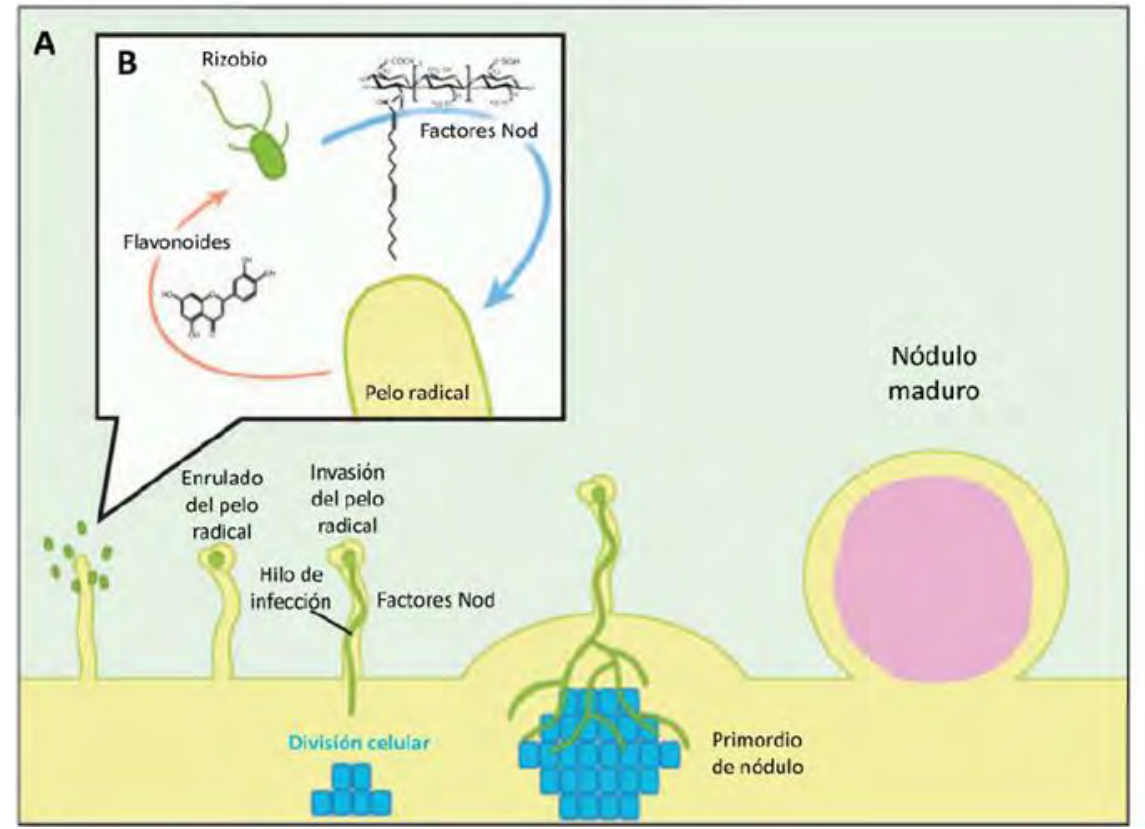

Figura I.2 - Modelo esquemático de la formación y desarrollo de los nódulos de leguminosas. El intercambio de señales comienza en la rizósfera, donde la planta libera flavonoides los cuales son detectados por el rizobio e induce la producción del factor Nod. La planta responde a la presencia del factor Nod e induce una curvatura en el pelo radical. El rizobio es capaz de infectar el pelo radical y formar el hilo de infección. Las células corticales de la planta comienzan a dividirse formando el primordio del nódulo. Luego el rizobio es liberado por endocitosis y se diferencia a bacteroide y es capaz de realizar la FBN. Modificado de Gibson y col. (2008).

En resumen, para que el proceso de formación de nódulos y la FBN sean posibles, son necesarios numerosos cambios transcripcionales tanto en la planta como en el rizobio. Este proceso es sumamente complejo y requiere de la coordinación de numerosos procesos independientes, como son el intercambio de señales, la infección, y la diferenciación de ambos organismos. Cada par simbiótico ha desarrollado diferentes estrategias a nivel molecular para lograr coordinar todas las etapas nombradas anteriormente y finalmente establecerse una simbiosis exitosa (JiménezGuerrero et al., 2017).

\section{Simbiosis Bradyrhizobium-Soja}

La soja es una leguminosa conocida por su valor nutricional. Principalmente el poroto de soja contiene gran cantidad de proteínas comparado con otros cultivos y es por esta razón que la demanda de $\mathrm{N}$ por parte de esta planta es muy elevada (Patil et al., 2017). Desde hace tiempo, existen productos comerciales llamados inoculantes (biofertilizantes) los cuales son utilizados para aumentar el rendimiento de estos cultivos, aprovechando la capacidad de FBN de los rizobios que establecen simbiosis con esta planta (Lodeiro, 2015). Para la formulación de estos productos se utilizan rizobios del género Bradyrhizobium (B. japonicum, B. diazoefficiens y B. elkanii), aunque estos no son los únicos rizobios capaces de nodular soja. 
En Argentina, la producción de soja ha ido aumentando a lo largo de estos últimos años estableciéndose como el tercer productor mundial de esta leguminosa, luego de Estados Unidos y Brasil, y consolidándose como uno de los principales exportadores de este producto (http://www.bolsadecereales.com/; https://inta.gob.ar/). Paralelamente a este aumento de la producción $y$ en pos de una agricultura sustentable, se han utilizado inoculantes biológicos para aumentar el rendimiento del cultivo. Estos productos han sido aplicados en los campos argentinos desde hace más de tres décadas y han sido muy aceptados gracias a su bajo costo y su simple aplicación (Lodeiro, 2015). Sin embargo, el aumento de la producción parece haber alcanzado una meseta, porque la cantidad de área de soja cultivable parece haber alcanzado un máximo (Lodeiro, 2015). Es así que para aumentar la producción es necesario aumentar la productividad por hectárea. De esta forma, la mejora de los inoculantes hasta ahora utilizados y mejoras en su aplicación cobran preponderancia y son objeto de desarrollo agrobiotecnológico.

\section{I.1.3 Problemática del uso de inoculantes para soja}

En suelos donde se han realizado campañas sucesivas de siembra de soja junto con la aplicación de inoculantes, se observa que la ocupación de nódulos por el rizobio proveniente del inoculante representa sólo un 5-20\% del total de nódulos que la planta logra generar. El resto proviene de cepas que se encuentran en el suelo y que en parte derivan de inoculaciones anteriores (McDermott y Graham, 1989). Loureiro y colaboradores (2006) han determinado que luego de 18 años sucesivos de utilización de inoculantes, los rizobios que se establecieron en el suelo presentaban nuevos perfiles genéticos. Esta diversidad podría tener un origen en la transferencia horizontal de genes entre las bacterias presentes en el suelo y las que se han utilizado en los bioinsumos. La problemática que se genera debido a este fenómeno es que generalmente los rizobios del suelo que sufrieron estos cambios genéticos a lo largo del tiempo, perdieron su capacidad de FBN, aunque al mismo tiempo lograron ser más competitivos para la ocupación de nódulos (Sadowsky y Graham, 1998). Este fenómeno se conoce como el problema de la competición para la nodulación. En nuestro laboratorio, desde hace más de 20 años se ha encarado este tema intentando dilucidar las variables que lo generan y posibles soluciones.

Parte de esta problemática está relacionada con la manera en que se practica el proceso de inoculación actualmente. El mismo consiste en la mezcla de un concentrado de bacterias junto con las semillas, previo a su siembra. Durante este proceso, puede generarse una distribución heterogénea de la cantidad de producto en las semillas y un decaimiento de la viabilidad de los rizobios al momento de realizarse la siembra. 
Otra de las variables es el tipo de adhesión que se produce entre la bacteria y la superficie de la semilla. Una vez que la semilla inoculada se coloca en el surco de siembra y se produce la germinación, las bacterias que están adheridas al tegumento de la semilla deben desprenderse y desplazarse hacia la zona de la raíz emergente susceptible a la infección (Bhuvaneswari et al., 1980). A mayores tiempos, se produce una adhesión irreversible de las bacterias que dificulta su posterior desprendimiento (Smit et al., 1992). Además, en el laboratorio determinamos que la movilidad vertical de las bacterias es escasa. Por este motivo, las bacterias que están establecidas en el suelo tienen una posición ventajosa respecto de las del inóculo y por lo tanto son capaces de encontrar las raíces, e infectarlas, más fácilmente. Este es uno de los aspectos más importantes que hace que la población establecida sea más competitiva que el inoculante.

Una de las posibles soluciones que hemos explorado consiste en un cambio en el método de inoculación. Este método, conocido como inoculación en el surco se siembra, se realiza colocando el inoculante $5 \mathrm{~cm}$ por debajo de la semilla. Esto mejora la posición de la bacteria del inoculante y por lo tanto su competitividad con respecto a la población naturalizada (López-García et al., 2009). Esta tecnología se encuentra disponible para su uso, pero su implementación requiere gran cantidad de inoculante líquido que debería ser transportado a la zona de aplicación, lo que elevaría los costos del proceso. La otra solución propuesta se basó en tratar de mejorar la movilidad de los rizobios inoculados sobre las semillas. Para ello, en nuestro laboratorio se obtuvo una cepa con mayor capacidad de natación (Althabegoiti et al., 2008), la cuál presentó también mayor capacidad de adhesión e infección a raíces en ensayos de laboratorio. Además, cuando esta cepa fue utilizada en ensayos a campo (donde las bacterias del inoculante compiten con la población de bacterias del suelo), se observó que ocupó una mayor proporción de nódulos con respecto a la planta inoculada con la cepa salvaje y asimismo se obtuvo un aumento significativo del rendimiento en grano (Althabegoiti et al., 2008; Lopez-García et al., 2009).

Si bien la capacidad de natación resultó un factor clave para la competitividad de la cepa utilizada en el inoculante, la habilidad de movimiento parece cobrar relevancia en ciertas condiciones hídricas. Cuando el sustrato está sobresaturado de agua (condición equivalente a inundación), aquellas cepas capaces de moverse pueden ocupar mayor número de nódulos en ensayos de competición frente a cepas inmóviles (Althabegoiti et al., 2011). Sin embargo, esto no se observa cuando el sustrato está a capacidad de campo. De esta manera, la capacidad de movimiento de las cepas utilizadas cobra importancia solamente en medios líquidos, o en medios porosos que se encuentran anegados.

Estas observaciones, sumado a la presencia de dos tipos de flagelos en $B$. diazoefficiens (Capítulo I.2), motivó un cambio de rumbo en los trabajos de investigación de nuestro grupo, principalmente para entender cómo hace esta bacteria para moverse, como regula la síntesis de sus flagelos, qué factores modulan su 
performance de natación en diferentes hábitats (inclusive en la complejidad del suelo) y finalmente, como aplicar los conocimientos adquiridos para mejorar la formulación de inoculantes. A lo largo de este Capítulo desarrollaremos en más detalle las particularidades de estos dos sistemas flagelares.

\section{I.2 La movilidad bacteriana}

\section{I.2.1 Importancia general en bacterias}

La capacidad de movimiento de las bacterias cobra gran importancia cuando las mismas se encuentran en estado planctónico, en vida libre. Incluso para aquellos microorganismos que infectan un hospedador (ya sea patógenos o simbiontes), la capacidad de moverse a través de mecanismos propios y no por simple difusión o movimiento Browniano, le confiere importantes ventajas.

El desplazamiento cerca de superficies es un ejemplo de algunas de estas ventajas. Mediante el nado cerca de superficies (near surface swimming), las bacterias son capaces de desplazarse en paralelo a una superficie (biótica o abiótica) y de esta manera alcanzar un sitio adecuado (como por ejemplo una herida) para infectar un hospedador, o en cambio, mediante el uso de mecanosensores establecerse en un nuevo nicho formando biofilms. Otra gran ventaja que poseen las bacterias que pueden movilizarse es la capacidad de detectar señales del ambiente y en respuesta a ello desplazarse hacia lugares más favorables (Chaban et al., 2015). Esto se conoce como natación dirigida (directed swimming). De esta manera, las bacterias son capaces de alejarse de una sustancia nociva o acercarse a una zona rica en nutrientes. En un primer momento, este proceso fue denominado quimiotaxis (por la respuesta a la concentración de diferentes sustancias químicas), pero existen otros estímulos que pueden ser percibidos por las bacterias. Ejemplos de ello son la fototaxis (respuesta a la luz), reotaxis (respuesta a corrientes de líquido), osmotaxis (respuesta a la osmolaridad), termotaxis (respuesta a la temperatura) y tigmotaxis (respuesta a vibraciones) (Chaban et al., 2015).

\section{I.2.2 Tipos de movimiento}

Las células procariotas son capaces de moverse en medios acuosos como también sobre superficies mediante mecanismos activos muy diversos, entre los que se encuentran el swimming (natación), swarming (movimiento en enjambre o en grupo sobre superficies), gliding (movimiento mediante el uso de adhesinas) o twitching 
(movimiento mediado por pili o fimbria) (Figura 1.3). Para que estos tipos de movimiento sucedan es necesaria la síntesis de ciertas estructuras, que funcionan como nanomotores y les permiten desplazarse (Jarrell y McBride, 2008). Otros tipos de movimiento son pasivos y utilizan otras ventajas físicas u otros organismos para llevarlas a cabo, como por ejemplo el floating o sliding. A continuación, realizaremos una breve reseña de cada una de estas formas de movimiento.

\section{Swimming y Swarming}

Los movimientos de swimming y swarming requieren la presencia de un largo apéndice extracelular llamado flagelo que, al rotar, genera la propulsión del cuerpo bacteriano.

El movimiento de swimming (natación) es utilizado para movimiento en medios acuosos. Mediante este tipo de movimiento la bacteria es capaz de realizar nearsurface swimming y directed swimming, como hemos mencionado previamente en la introducción de esta sección. El movimiento de natación es el mecanismo más veloz mediante el cual las bacterias son capaces de desplazarse individualmente, nadando a velocidades entre $25-160 \mu \mathrm{m} / \mathrm{s}$, dependiendo la especie bacteriana (Jarrell y McBride, 2008).

Por otro lado, el movimiento tipo swarming es un movimiento multicelular (en masa) que se realiza sobre una superficie. Para realizar este tipo de movimiento, las bacterias suelen hiperflagelarse (aumentan la cantidad de flagelos sintetizados), y secretan sustancias surfactantes. Además, se requiere una coordinación para el movimiento en masa mediante quorum sensing (Harshey, 2003).

\section{Twitching y Gliding}

Existen diversas especies de bacterias que son capaces de moverse sobre una superficie utilizando mecanismos independientes de los flagelos. Dos de estos tipos de movimientos se denominan twitching y gliding. La primera forma de movimiento es realizada gracias a la acción de otro apéndice denominado pilus tipo IV (Mattick, 2002). Esta estructura es capaz de extenderse y adherirse a una superficie que se encuentra en un sitio lejano, y luego el cuerpo bacteriano es desplazado hacia allí gracias a la retracción de los pili (Skerker y Berg, 2001). Este mecanismo descripto anteriormente genera que este tipo de movimiento sea espasmódico y solo llega a alcanzar una velocidad de 0,05-1 $\mu \mathrm{m} / \mathrm{s}$ (Jarrell y McBride, 2008).

El movimiento tipo gliding en cambio, suele utilizar adhesinas y producción de exopolisacáridos (EPS) para deslizarse sobre superficies. Este mecanismo es muy diverso y complejo, y hasta el momento solo se ha descripto en bacterias como Flavobacterium johnsoniae, Myxococcus xanthus y Mycoplasma mobile. La velocidad mediante este tipo de movimiento es tan variada como los mecanismos de acción involucrados en cada microorganismo y pueden ir desde $2-4 \mu \mathrm{m} / \mathrm{s}$ a $2-4 \mu \mathrm{m} / \mathrm{min}$ (Jarrell y McBride, 2008). 

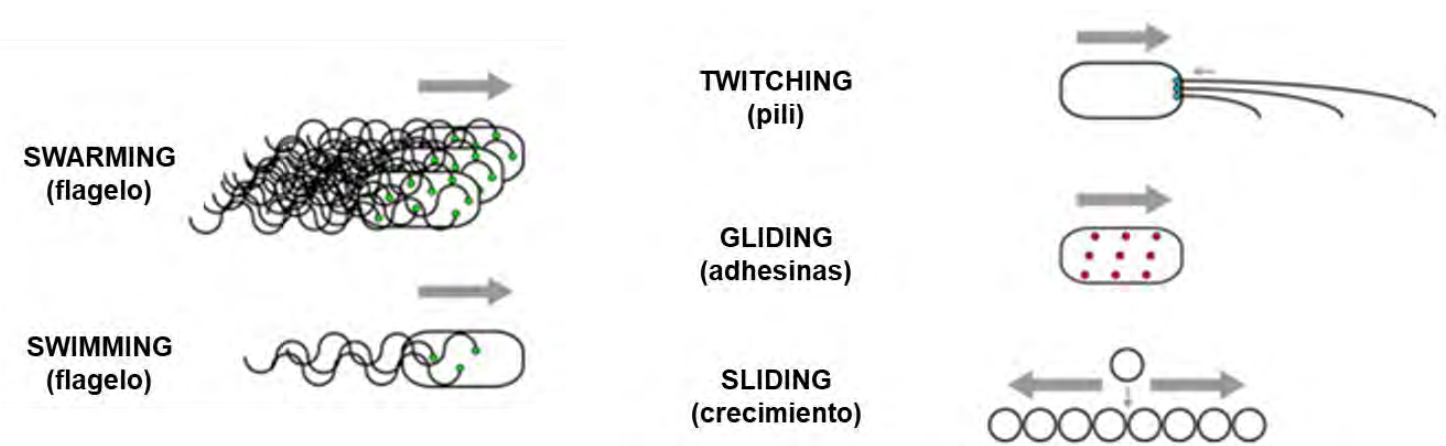

Figura 1.3 - Tipos de movimiento bacterianos. La imagen muestra cuatro tipos de movimiento activo (swimming, swarming, twitching y gliding) y entre paréntesis se muestran las estructuras que son requeridas para realizarlos. Además, se muestra el esquema de un tipo de movimiento pasivo (sliding) propulsado por el crecimiento y la liberación de sustancias surfactantes. Extraído y modificado de Kearns (2010).

\section{Mecanismos de movimiento pasivos}

Algunas bacterias pueden moverse mediante mecanismos pasivos realizando floating, que consiste en la flotabilidad de células mediante la formación de vesículas de gas que le permiten moverse en columnas de agua. Este mecanismo se da generalmente en bacterias acuáticas y arqueobacterias. Otro tipo de movimiento pasivo es el sliding, el cual se produce a través del crecimiento bacteriano sumado a la liberación de sustancias surfactantes que le permiten "resbalar" sobre la superficie (Kearns, 2010).

Las bacterias del suelo, además, utilizan otros organismos que habitan en el mismo ambiente para moverse (foresis), entre los que se encuentran nematodos y micelios de hongos (Horiuchi et al., 2005; Kohlmeier et al., 2005). Por otro lado, ciertos procariotas que son parásitos intracelulares manipulan la maquinaria del huésped (polimerización polar de actina) para migrar de una célula a otra (Jarrell y McBride, 2008).

\section{I.3 Movimiento bacteriano mediante flagelos}

\section{I.3.1 Descripción general}

Los flagelos son estructuras muy complejas compuestas por 30-50 proteínas distintas dependiendo de la especie bacteriana. Además, cada componente es requerido en distinta cantidad de copias que van desde unas pocas a decenas de miles de monómeros (Chaban et al., 2015). El apéndice externo del flagelo tiene forma helicoidal y su longitud promedio es de $10 \mu \mathrm{m}$ (Saier, 2013). Teniendo en cuenta que 
las bacterias miden entre 0,5-5 $\mu \mathrm{m}$ de largo, el flagelo puede superar, según la especie, varias veces el largo del cuerpo bacteriano.

Como mencionamos anteriormente, el flagelo le permite a la bacteria desplazarse a gran velocidad en medios líquidos mediante el movimiento de natación o sobre superficies realizando swarming. El rango de velocidades que la bacteria puede alcanzar utilizando esta maquinaria depende de muchos factores, como son la forma de la bacteria, la fuente de energía que utiliza el motor del flagelo para rotar y las proteínas que forman parte de la estructura de ese motor (Kearns, 2010). Otro factor importante que afecta el funcionamiento del flagelo responde al estado metabólico energético en que se encuentre la célula. Se estima que los flagelos pueden llegar a consumir hasta el $2 \%$ del total de los recursos metabólicos de una bacteria (Guttenplan y Kearns, 2013; Cogo et al., 2018). Además, la capacidad de movimiento depende fuertemente del ambiente en que la bacteria se encuentre. La velocidad de nado en medios viscosos o tortuosos (como podría ser sobre las raíces o entre las partículas del suelo) se verá mucho más reducida o en todo caso, interrumpida.

Los flagelos son estructuras que se encuentran altamente conservadas en todas las bacterias, sin embargo, el patrón de flagelación varía entre especies. Pueden estar ubicados en un polo de la bacteria o en los laterales, y pueden ir desde 1 a 25 en Bacillus subtilis, hasta algunos cientos en Vibrio parahaemolyticus. Esta variablilidad hace que la localización y el número de flagelos en cada bacteria sea muy particular (Schuhmacher et al., 2015). Así, la cantidad y localización de los flagelos que cada especie posee determinan patrones de flagelación llamados monótrico, anfítrico, lofótrico y perítrico (Figura 1.4). Aquellas bacterias que presentan dos sistemas de flagelos independientes, como por ejemplo B. diazoefficiens, presentan dos patrones de flagelación (monótrico para el flagelo subpolar y perítrico para los flagelos laterales).

En ciertas bacterias, se han descripto mecanismos y proteínas específicas (denominadas "landmark proteins") responsables de la ubicación del flagelo en una posición determinada del cuerpo bacteriano. Además, el patrón de flagelación puede modificarse en función de diferentes condiciones ambientales o a lo largo del ciclo celular. Incluso, en algunos casos, se ha observado que el contacto con una superficie puede inducir un aumento en la cantidad de flagelos sintetizados (Schumacher et al., 2015). 


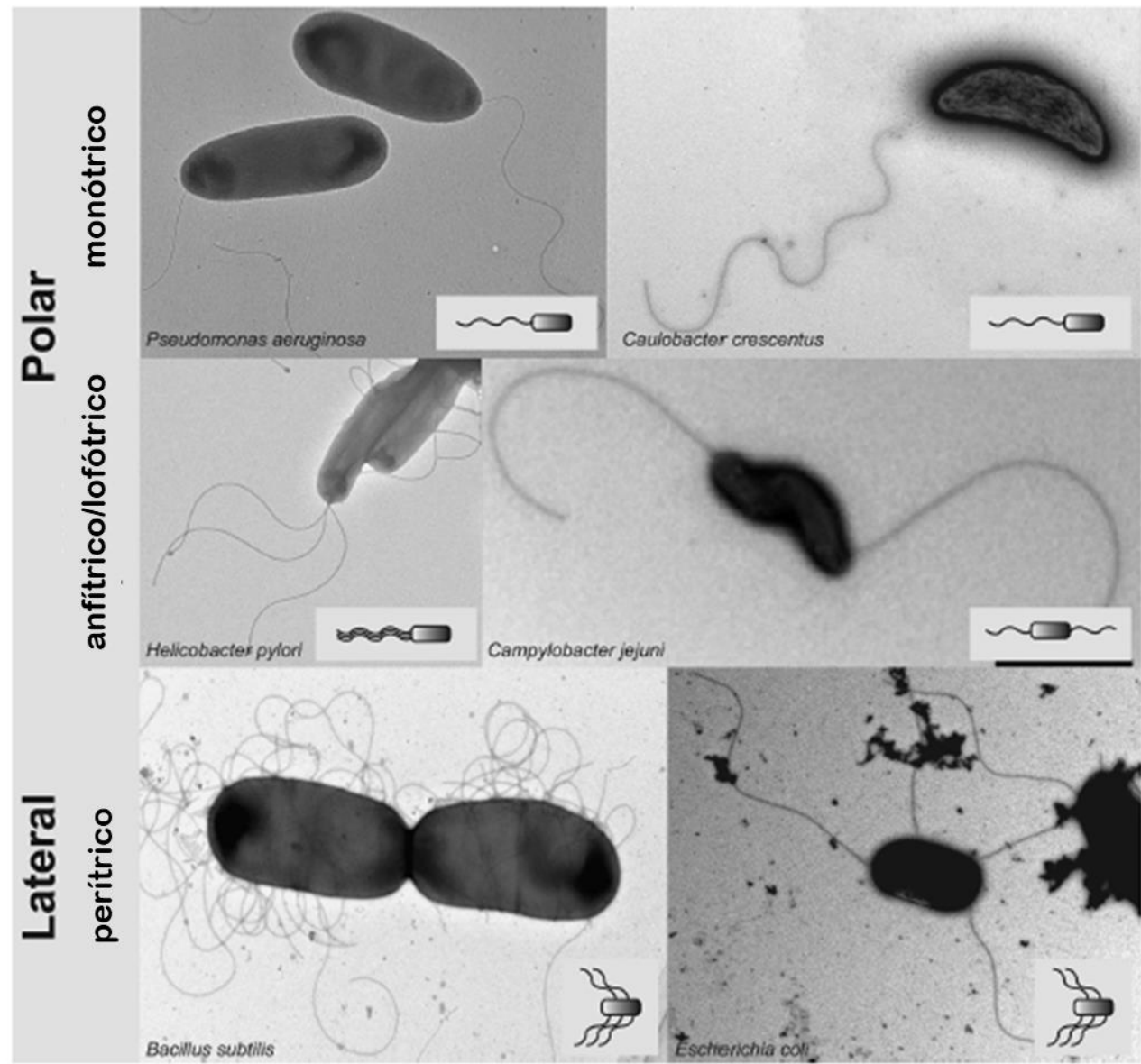

Figura 1.4 - Patrones de flagelación en diversas especies bacterianas visualizadas a través de microscopía electrónica. Flagelación polar: $P$. aeruginosa, $C$. crescentus (monótrico), H. pylori (lofótrico), C. jejuni (anfítrico). Flagelación lateral: B. subtilis y E. coli (perítrico). Extraído y modificado de Schuhmacher y col. (2015).

\section{Estructura del flagelo bacteriano}

El flagelo consta de tres partes principales denominadas cuerpo basal, gancho y filamento (Macnab, 2003). Ver Figura I.5

\section{Cuerpo basal}

El cuerpo basal es la estructura anclada a la pared bacteriana que transmite el torque producido por el motor hacia el gancho y luego al filamento. Está compuesto por una serie de anillos integrados en cada una de las membranas bacterianas, y atravesados por un bastón. En la membrana citoplasmática se encuentra inserto uno de los anillos, denominado anillo MS, un bastón que atraviesa el espacio periplásmico, un anillo $P$ en la pared de peptidoglucano (solo en bacterias Gram negativas), y un anillo L integrado a la membrana externa. Además de estos anillos anclados a membrana, también se forma un anillo $C$ en el citoplasma formado por las proteínas FliM y FliN que participan en la modificación de la dirección de natación de la bacteria en respuesta a señales ambientales (Macnab, 2003). 


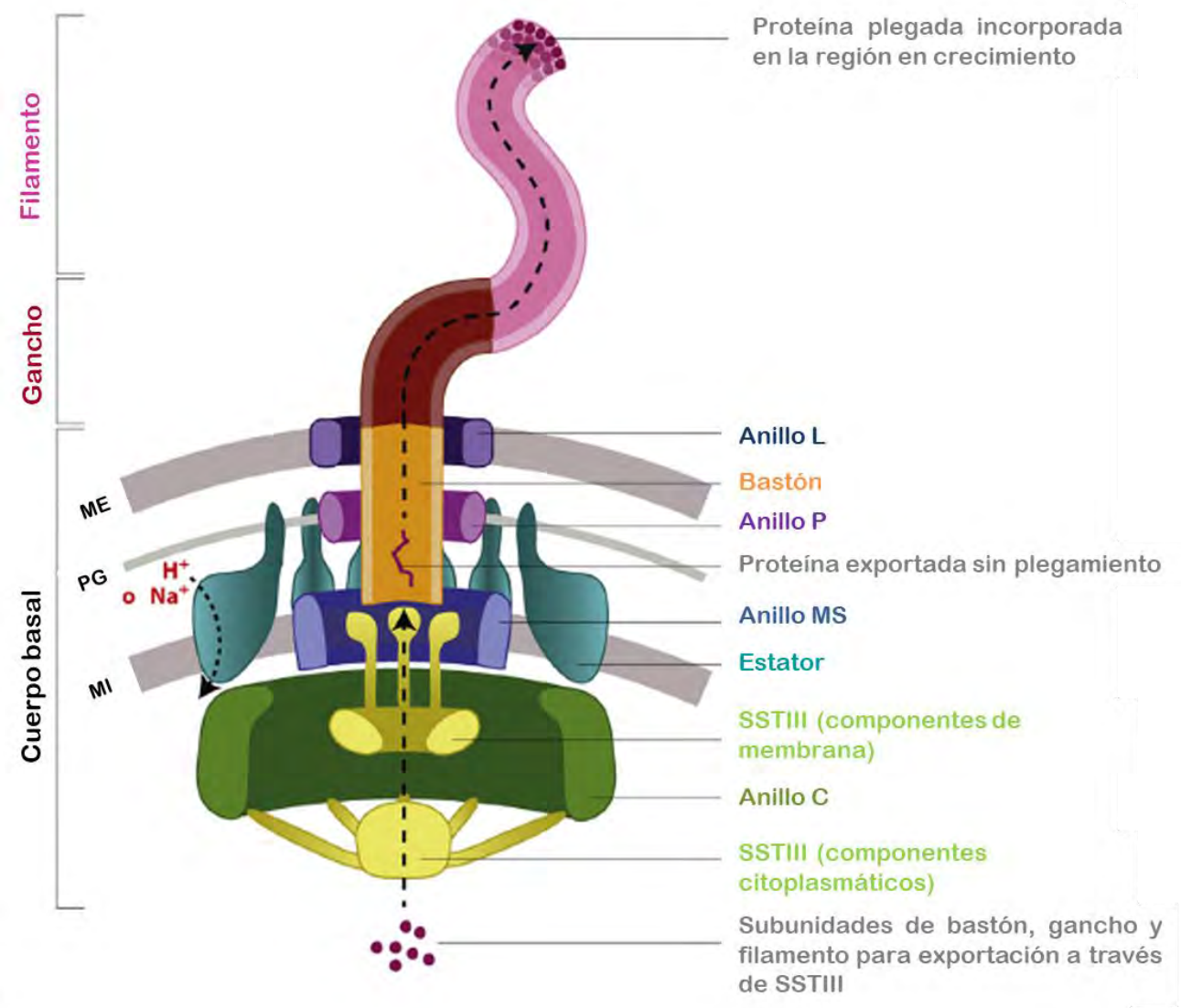

Figura 1.5 - Componentes del flagelo bacteriano. La imagen muestra a la izquierda los tres componentes principales del flagelo: cuerpo basal, gancho y filamento. A la derecha se muestran las subestructuras que componen el cuerpo basal en colores y en gris se esquematiza como se exportan las proteínas del bastón, gancho y filamento. Imagen extraída y modificada de Chaban y col (2015).

El bastón es la primera estructura cilíndrica sintetizada de carácter rígido que actúa como eje de transmisión del torque hasta el gancho. El bastón se extiende desde el anillo MS, atraviesa la membrana externa y se comunica con el gancho y se divide en dos subestructuras, un bastón proximal y bastón distal. Los nombres se refieren a la ubicación, siendo el bastón proximal el que se ubica más cerca del anillo MS, y el bastón distal el que se encuentran cerca del gancho. (Imada, 2018).

Otra de las estructuras necesarias para el funcionamiento del flagelo es el motor. Esta estructura está compuesta por dos partes: un estator, formado por dos proteínas de membrana denominadas MotA y MotB que se encuentran unidas de manera no covalente con la pared de peptidoglucano; y un rotor formado por FliG que se encuentra unido no covalentemente al anillo MS y a las proteínas Mot y es importante para la generación del torque que permitirá la rotación del filamento y para cambiar la dirección de movimiento (switch) del flagelo.

El motor aprovecha la diferencia de potencial químico (fuerza protón motriz) producido por la diferencia de concentración de protones $\left(\mathrm{H}^{+}\right)$existente entre el 
espacio periplásmico y el citoplasma bacteriano. El paso de iones ocurre a través de un canal formado por el estator y rotor. Generalmente el $\mathrm{H}^{+}$se une a residuos conservados de MotB, causando un cambio conformacional que es trasladado al rotor y luego hacia las estructuras tubulares del bastón, gancho y filamento. Finalmente el $\mathrm{H}^{+}$es liberado en el interior celular y el estator retorna a su conformación original (Macnab, 2003). En bacterias marinas como V. parahaemolycus se ha encontrado que la fuerza del motor proviene del flujo de iones sodio $\left(\mathrm{Na}^{+}\right)$en lugar de $\mathrm{H}^{+}$. En estas bacterias, las proteínas homólogas de MotAB se denominan PomAB (Baker y O'Toole, 2017).

Asociados al anillo citoplasmático se ubica un complejo de proteínas que intervienen en la secreción de proteínas extracelulares formando un sistema de secreción tipo III (SSTIII). Estas proteínas reclutan, desestructuran y exportan proteínas que van a formar las estructuras tubulares: bastón, gancho y filamento del flagelo. Este sistema de secreción especializado es muy parecido a otros SSTIII no flagelares. Primero, se forma un canal en el centro de la estructura naciente y luego, las subunidades que atraviesan el mismo difunden a través de él y se ensamblan cuando alcanzan el extremo de la estructura que se está sintetizando.

\section{Gancho}

El gancho es la primera estructura cilíndrica que se ubica fuera de la bacteria y funciona como un empalme universal entre la estructura anclada a membrana y el filamento. Dada la flexibilidad de esta estructura, es capaz de transmitir el torque producido en cada revolución del motor a través del bastón, hacia la estructura coaxial del filamento de una manera constante y suave. Gracias a esta estructura, las bacterias que poseen más de un flagelo logran ubicarlos en una única dirección, enroscarlos formando "manojos", y de esta manera consiguen sincronizarlos para trasladarse en un sentido determinado (Imada, 2018). Además, entre el filamento y el gancho, se ubican otras proteínas de unión que sirven de adaptadores entre ambas estructuras y permiten el correcto ensamblado de las mismas (Imada, 2018).

\section{Filamento}

El filamento también es una estructura cilíndrica, mucho más larga que el gancho y con forma helicoidal que, al rotar a modo de hélice, genera la propulsión que le permite a la bacteria moverse. Esta estructura está compuesta por miles de proteínas llamadas flagelinas y es la principal estructura que se observan en las microscopías electrónicas de barrido o de transmisión (tinción negativa). 


\section{I.3.2 Ensamble del flagelo}

En general las subestructuras flagelares son ensambladas en orden y de manera secuencial, comenzando por las estructuras proximales hacia las distales. Ello quiere decir que su síntesis se inicia con el ensamblaje de proteínas integrales de membrana, luego con componentes periplásmicos y finalmente componentes que se encuentran en el exterior celular (Macnab, 2003). En general, las proteínas flagelares se mantienen conservadas en los distintos microorganismos, al igual que la forma en que son ensambladas. En la Figura S.1, que se encuentra adjuntada en este trabajo, se graficó una imagen del flagelo con cada una de las proteínas que lo conforman que permitirá a los lectores comprender mejor cómo se ubican y ensamblan dentro de la estructura.

Uno de los primeros eventos de ensamblaje del flagelo comienza con la inserción de componentes de membrana (anillos MS-L-P) en su respectiva posición mediante el sistema Sec-pathway (Homma et al., 1987; Macnab, 2003). Mediante este mecanismo, y sin el requerimiento de ninguna otra proteína flagelar, se ensambla inicialmente el anillo MS, la primera subestructura del flagelo formado por la proteína FliF. Este primer anillo actúa como guía para el montado de las subestructuras del rotor y switch del flagelo, además de conectar (vía FliE) con el bastón y favorecer el reclutamiento del aparato de exportación del SSTIII.

FliG es la proteína que forma el rotor y junto con FliM y FliN (que componen el anillo $C$ encargado del switch del flagelo) parecen autoensamblarse a continuación de FliF. En cambio, las proteínas que componen el estator, MotA y MotB, no son ensambladas en un momento particular durante la formación del flagelo, sino que pueden insertarse en la membrana en cualquier instante. Estas proteínas del estator interactúan constantemente con las proteínas del rotor y anillo C. Además de estas proteínas, existe otra proteína denominada FliL que interacciona con el estator, y dicha unión estabilizaría el flagelo cuando la viscosidad del medio es elevada (Partridge et al., 2015; Zhu et al., 2015). Al igual que las proteínas Mot, las proteínas FliL se sintetizan en mayor cantidad de acuerdo con un aumento de la viscosidad del medio (Baker y O'Toole, 2017).

Los Anillos L y $\mathrm{P}$ están formados por las proteínas Flgl y FlgH respectivamente. Ambas proteínas poseen un péptido de señalización que resulta indispensable para la exportación primaria o a través de Sec-pathway. El momento de exportación de estas proteínas no se conoce, incluso podrían encontrarse como monómeros en la pared o membrana antes del ensamblaje del anillo MS. Particularmente, Flgl necesita de una chaperona FlgA, la cual evita la proteólisis de esta proteína en el espacio periplásmico (Nambu y Kutsukake, 2000).

Una vez formados los anillos MS y C, es necesario que se ensamble el SSTIII para poder exportar las proteínas del bastón, gancho y filamento. 
El SSTIII está conformado por tres proteínas solubles (FliH, Flil y FliJ) y seis proteínas asociadas a membrana (FlhA, FlhB, FliO, FliP, FliQ y FliR). Las tres proteínas citosólicas (FliHIJ) forman el complejo ATPasa, mientras que FlhAB y las FliOPQR forman el canal de exportación dentro del anillo MS (Minamino et al., 2008).

El proceso de exportación es realmente complejo (Ver Figura I.6). FliH actúa como estator y es responsable de un gran número de interacciones con otras proteínas del sistema de secreción o del anillo C. Principalmente, FliH forma un complejo con Flil, que es la proteína que posee actividad ATPasa. FliJ por su parte, actúa como chaperona general de las proteínas que serán exportadas a través del sistema. De esta manera, FliJ se une a un sustrato determinado y se une con FliHI, el cual en un primer momento se encuentra interaccionando con el anillo C (FliN). Producto de la unión con la chaperona, el nuevo complejo FliHIJ se libera del anillo C e interacciona con FlhA, alcanzando el canal de exportación. Luego, el sustrato comienza a ser exportado a partir de la región $\mathrm{N}$-terminal mediante un sistema antiporte (Proteína-flujo de $\mathrm{H}^{+}$). Luego, Flil degrada ATP y de esta manera consigue separarse el complejo FliHIJ, liberar el canal de exportación y reiniciar el proceso (Minamino et al., 2008).

FlhB participa de la especificidad del sustrato que se requiere translocar. Esta proteína sufre un proceso de autoproteólisis que sería el responsable de permitir que se cambie la proteína que será exportada (Minamino y Macnab, 2000).

FliE es una de las primeras proteínas exportadas por este sistema y sirve de unión entre el anillo MS y el bastón, el cual será ensamblado a continuación. El bastón está compuesto por cinco proteínas diferentes: FlgB, FlgC, FlgF, FlgG y FlgJ. FlgBCF forman el bastón proximal y FlgG forma el bastón distal. FlgJ, en cambio, posee función cap (de tapa) y actividad muramidasa que permite la rotura de la pared de peptidoglucano para que el bastón sea capaz de atravesar la misma (Macnab, 2003). 


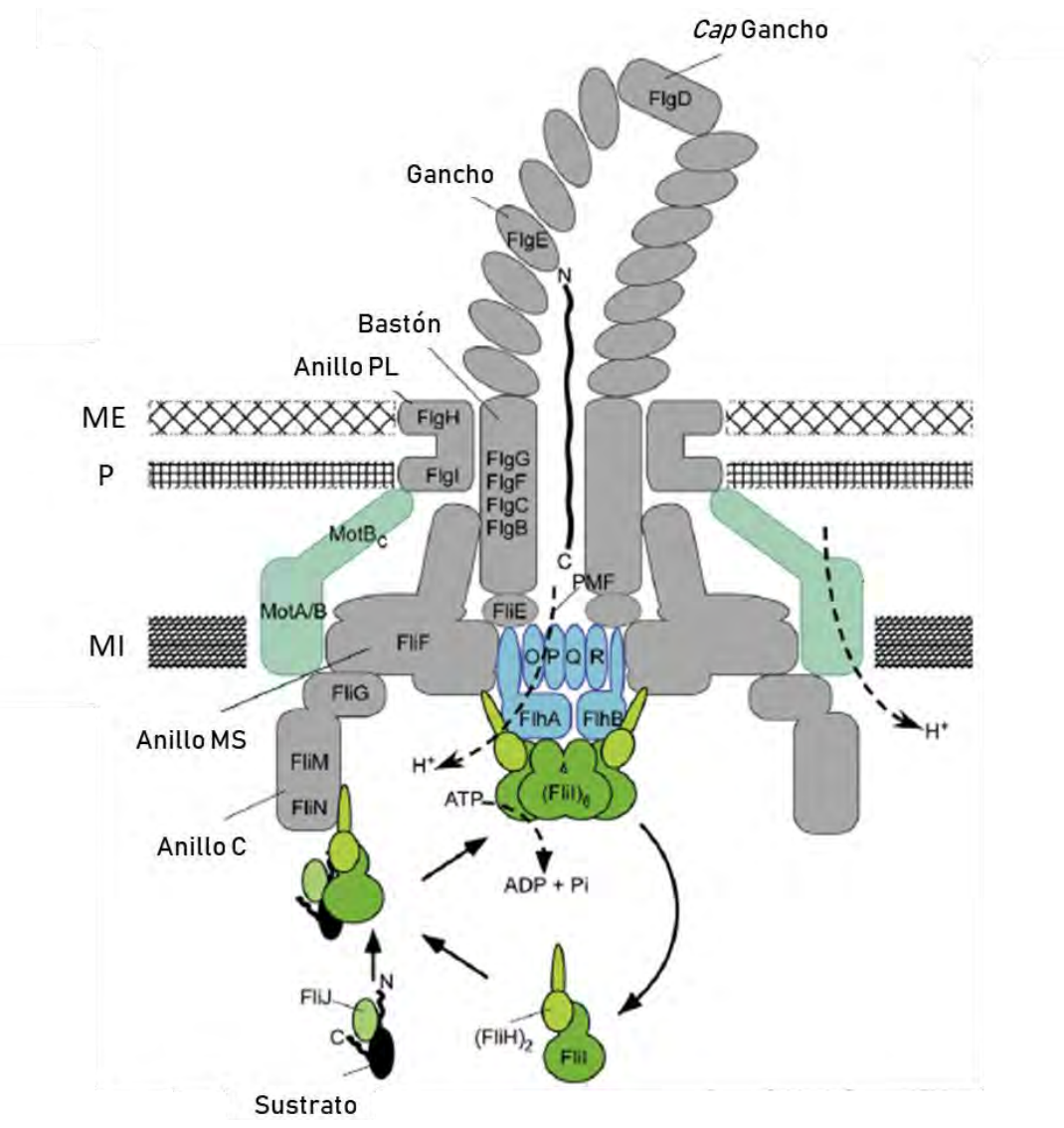

Figura I.6 - Sistema de secreción de tipo III asociado al flagelo. En verde se encuentra representado el complejo ATPasa (FliHIJ) y en celeste el complejo que forma el canal de exportación (FlhAB y FliOPQR). FlilH interacciona con FliN en el anillo C, luego interacciona la chaperona FliJ unida al sustrato y el complejo FlilHJ-sustrato se libera e interacciona con la proteína FlhA en el canal de exportación. El sustrato es traslocado y FliHI y FliJ se desprenden del canal gracias a la degradación de ATP por parte de Flil. Extraído y modificado de Minamino y col. (2008).

Las proteínas con función cap, cierran el conducto en formación para evitar entrada y salida de sustancias de la célula. Estas proteínas se unen a la estructura en formación en un primer momento y luego las proteínas estructurales son ensambladas por debajo de ellas. Una vez que la estructura se completa estas proteínas no permanecen en la estructura. Existen proteínas cap para el bastón (denominada FlgJ), el gancho (FlgD) y el filamento (FliD) (Imada, 2018).

Como mencionamos recién, luego de formarse el bastón comienza el reemplazo de la proteína cap del bastón por la proteína cap FlgD y luego el agregado de la proteína principal FlgE para formar el gancho. Flik es la proteína que se encarga de controlar este proceso. El mecanismo mediante el cual Flik es capaz de regular el largo final de la estructura no se conoce con exactitud, pero se estima que sucede a través del autoclivaje de FlhB y a su vez, por el "acomodamiento" de un número determinado de proteínas en el anillo C (Macnab, 2003; Imada, 2018).

Una vez que el gancho alcanzó su tamaño determinado, la proteína cap es descartada y reemplazada por tres zonas sucesivas de proteínas, las primeras dos 
llamadas proteínas de unión gancho-filamento (FlgK y FlgL) y la última con la proteína cap del filamento (FliD). Las primeras dos zonas quedan unidas en ese sitio y los monómeros de flagelinas (FliC) van ensamblándose a continuación desplazando la zona formada por la proteína cap. El filamento está formado por más de 20.000 subunidades de flagelinas (Macnab, 2003). A diferencia del gancho, no existe un control de la longitud del mismo, pero este se autoregularía de una manera hasta el momento desconocida. Los flagelos demasiado largos suelen quebrarse, aunque luego pueden volver a crecer (Turner et al., 2012). La proteína cap evita principalmente la pérdida de monómeros de flagelinas al medio, a la vez que favorece la eficiencia de ensamblado de las flagelinas (Ikeda et al., 1993).

Además de estas proteínas, también existen proteínas que actúan de chaperonas de otras proteínas estructurales y de esta manera impiden la oligomerización dentro de la célula, estabilizan las proteínas y favorecen su exportación. FlgN es una de ellas y protege a las proteínas de unión entre el gancho y filamento (FlgK y FlgL), FliT actúa de chaperona de la proteína cap FliD, y FliS estabiliza las flagelinas FliC (Page y Parsot 2002; Macnab, 2003).

\section{I.3.3 Regulación génica de la síntesis flagelar}

La biosíntesis de flagelos bacterianos es un proceso complejo y muy ordenado que requiere una regulación coordinada, temporal y espacialmente, de un número amplio de genes diferentes que codifican las proteínas mencionadas anteriormente. Esta coordinación temporal se da a través de una jerarquía transcripcional (Smith y Hoover, 2009). De esta forma, la regulación temporal de la transcripción génica provoca una expresión secuencial (cascada) de las proteínas que conforman las distintas estructuras del flagelo, de manera que se sintetizan en el momento en que son requeridas para ensamblarse. Además de la jerarquía transcripcional, existen también puntos de chequeo (checkpoints) a lo largo del proceso que permiten coordinar cada etapa de la construcción del flagelo (McCarter, 2006).

Las cascadas regulatorias descriptas hasta el momento en distintas especies presentan variaciones entre ellas. (Figura I.7). Algunas cascadas regulatorias se dividen en 3 o 4 etapas diferentes y cada una de estas etapas se encuentra regulada por diversas proteínas. Algunas de ellas son factores transcripcionales, otros factores sigma alternativos y algunas de ellas son factores post-transcripcionales. Dada la variedad de proteínas reguladoras, cada una de estas cascadas flagelares se encuentran entrecruzadas con otras vías de señalización que afectan directamente la síntesis de la estructura (Smith y Hoover, 2009). Por ejemplo, algunos reguladores flagelares se encuentran interconectados con factores internos, como la fase del ciclo celular o el estado energético de la bacteria, o a factores ambientales como la temperatura u osmolaridad (Smith y Hoover, 2009). 


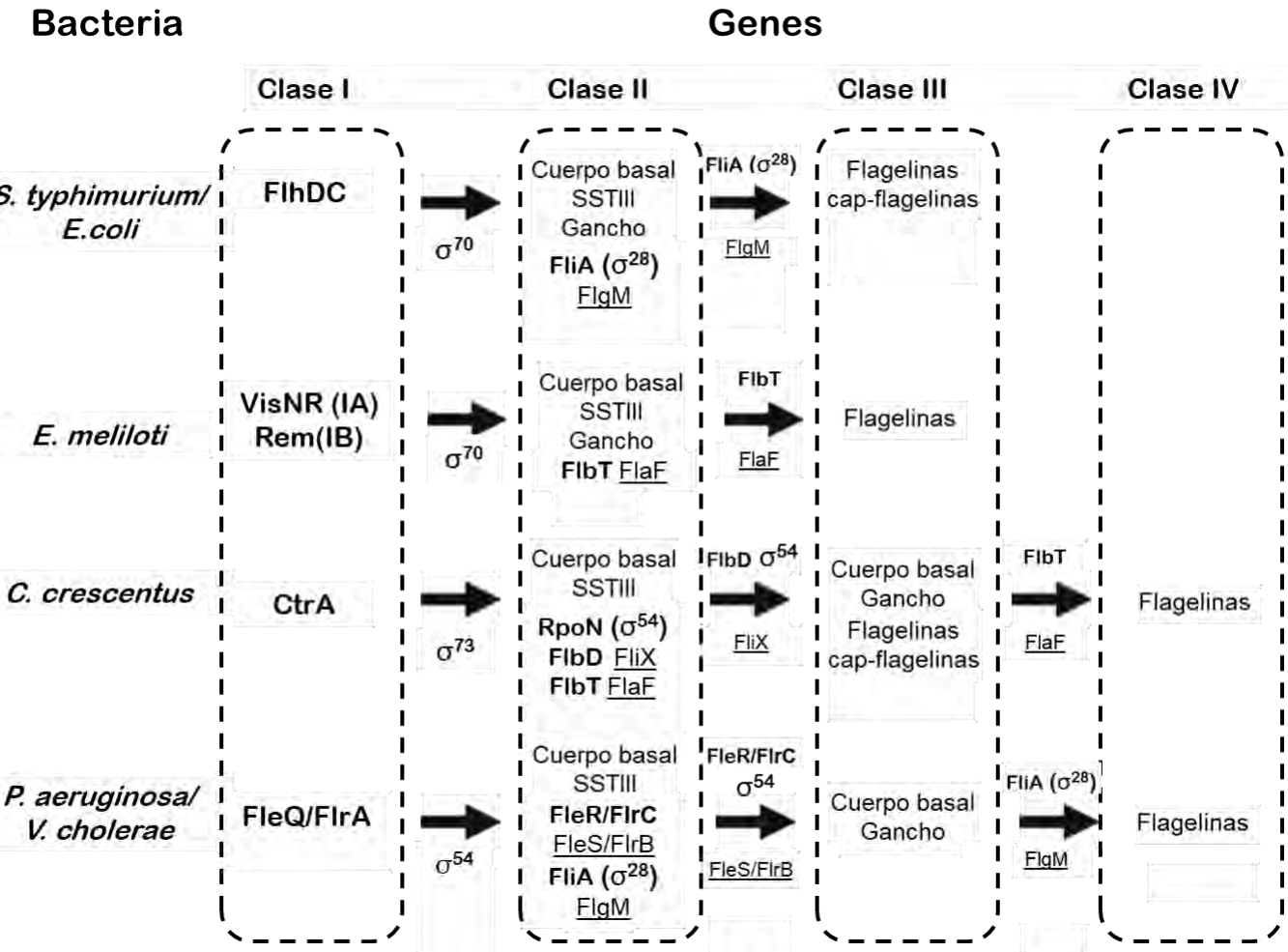

Figura I.7 - Esquema regulatorio de la síntesis flagelar. Se muestran cuatro esquemas regulatorios diferentes. Los genes y proteínas implicadas en la cascada se clasifican en clase I, II, III o IV de acuerdo a la etapa en que son transcriptos/sintetizados. Sobre las flechas se muestran los reguladores que son requeridos en cada etapa y las proteínas que actúan como checkpoints se encuentran subrayadas. Modificado de Smith y Hoover (2009).

\section{Cascadas regulatorias}

Los reguladores maestros o de clase I son los que inician la cascada regulatoria. Estos reguladores son factores de transcripción que actúan principalmente sobre los genes que codifican las primeras proteínas necesarias para ensamblar el flagelo (en su mayoría las del cuerpo basal). En la literatura se encuentran descriptos una gran variedad de reguladores maestros (Figura 1.7). Luego de la acción del regulador maestro, actúan otros reguladores, denominados de clase II o III, dependiendo de la etapa en la que ejercen su función. A continuación, se desarrolla una breve descripción de algunos de los modelos regulatorios conocidos hasta el momento.

Cascada regulatoria en Escherichia coli y Salmonella typhimurium

FlhDC es el regulador maestro más estudiado ya que desencadena la síntesis flagelar en E. coli y $S$. typhimurium. Este regulador actúa junto con el factor $\sigma^{70}$ de la ARN polimerasa y se encuentra distribuido en el $44 \%$ de las $\beta$ y $\gamma$-Proteobacterias (Kutsukake et al., 1990; Smith y Hoover, 2009). 
FlhDC está controlado a nivel transcripcional por varios reguladores que responden a cambios ambientales como son la temperatura, $\mathrm{pH}$, osmolaridad y disponibilidad de la fuente de carbono e incluso su síntesis se encuentra íntimamente relacionada con la división celular. Además de esta intensa regulación transcripcional, FIhDC se encuentra regulada también a nivel post-transcripciona (estabilidad del ARNm) y post-traduccional (degradación proteica) (Prüss y Matsumura, 1997; Claret y Hughes, 2000).

Luego de la acción de FlhDC, toda la estructura del flagelo es ensamblada a excepción del filamento. Previo al ensamblaje del gancho, FlgM (denominado factor anti- $\sigma$ ) se une a FliA $\left(\sigma^{28}\right)$ y lo secuestra. Luego, cuando el gancho se encuentra ensamblado, FlgM es liberado al exterior celular a través de la estructura del aparato flagelar en formación. De esta manera, FliA $\left(\sigma^{28}\right)$ queda disponible para activar la transcripción de las proteínas que darán lugar al filamento y concluirán la formación del flagelo (Ishihama, 2018).

\section{Cascada regulatoria en Ensifer meliloti}

En esta especie se han descripto dos reguladores maestros, denominados VisNR (regulador clase IA) y Rem (regulador clase IB). VisNR se encuentra regulado por tres factores transcripcionales principalmente relacionados con el quorum sensing y la producción de EPS. Este regulador, junto con $\sigma^{70}$, activa el segundo regulador Rem, el cual actúa con el mismo factor $\sigma$ activando la transcripción de los genes flagelares. Luego de la acción de estos dos reguladores FlbT y FlaF regulan de manera posttranscripcional a las flagelinas que formaran el filamento del flagelo (Ferooz et al., 2011).

\section{Cascada regulatoria en Caulobacter crescentus}

CtrA es un regulador maestro que ha sido muy estudiado en C. crescentus. Esta bacteria posee un peculiar modo de división celular que ha permitido su estudio en gran profundidad (Davis y Viollier, 2001; Laub et al., 2002; Reisenger et al., 2007; Angelastro et al., 2010). Es así que el regulador maestro del flagelo es a su vez un regulador del ciclo celular. CtrA actúa con $\sigma^{73}$ y se encuentra distribuida en la gran mayoría de las $\alpha$-Proteobacterias (Brilli et al., 2010). Sin embargo, en algunas de ellas sólo posee función relacionada con el ciclo celular y no con la síntesis flagelar como es el caso de E. meliloti (para más información ver Capítulo IV).

La transcripción de ctrA se encuentra regulada por dos factores transcripcionales involucrados en el ciclo celular. Para poder ejercer ambas funciones, CtrA es fosforilada (CtrA-P) y es en este estado donde es capaz de iniciar la transcripción de los genes tempranos de la síntesis flagelar y a su vez unirse al origen de replicación del genoma para frenar la replicación. Es por esta razón que la fosforilación de CtrA se encuentra muy regulada y está dada por un sistema complejo de transferencia de fosfatos (phosphorelay) (Para más información ver Capítulo IV). Además, CtrA también posee regulación post-traduccional (Ardissone y Viollier, 2015). 
Luego de la acción de CtrA, FlbD y FliX son los encargados de continuar la síntesis flagelar. FliX actúa como checkpoint del ensamble del cuerpo basal y el SSTIII, mientras que FlbD es un factor transcripcional dependiente de $\sigma^{54}$. Estos reguladores concluyen la formación del cuerpo basal y el gancho del flagelo (Muir et al., 2005).

En este modelo regulatorio las flagelinas se encuentran reguladas negativamente a través de FlbT por regulación post-transcripcional. Por su parte FlaF, participaría del último checkpoint impidiendo la acción de FlbT y favoreciendo la traducción de las flagelinas en el momento correcto (en el Capítulo VI se describe con más detalle la acción de estos reguladores).

Cascada regulatoria de Pseudomonas aeruginosa y $V$. cholerae

Los reguladores FleQ y FlrA son unos de los pocos reguladores maestros que actúan con $\sigma^{54}$ y fueron descriptos en $P$. aeruginosa y $V$. cholerae respectivamente. Este tipo de reguladores están compuestos por tres dominios, uno REC, de activación por fosforilación, uno AAAt, de degradación de ATP, y otro HTH, de unión a ADN. FleQ actúa coordinadamente con el segundo mensajero c-di-GMP regulando la producción de EPS y conectando el paso del estado planctónico al de formación de biofilms (Dasgupta y Ramphal, 2001).

Luego de la acción de FleQ/FIrA y la formación parcial del cuerpo basal y el SSTIII, otros reguladores dependientes de $\sigma^{54}$ serán encargados de dirigir la segunda etapa regulatoria. Estos son FleR/FlrC, los cuales son activados por fosforilación de las quinasas FleS/FIrB (McCarter, 2006). Estas últimas proteínas serían responsables del primer checkpoint en esta cascada de señalización. Una vez finalizado el ensamble del cuerpo basal y el gancho, se produce la última etapa de la síntesis del filamento, la cual se encuentra regulada por FlgM-FliA de manera similar a la descripta para E. coli y $S$. typhimurium.

\section{I.3.4 Funciones de los flagelos bacterianos}

En un comienzo, los flagelos fueron considerados únicamente como una estructura compleja involucrada en la movilidad bacteriana. Sin embargo, investigaciones recientes han revelado que tienen otras funciones, como la adhesión a superficies, la formación de biofilms, la secreción de moléculas efectoras, e incluso son necesarios durante la infección y modulación del sistema inmune del huésped tanto en bacterias patógenas como comensalistas (Chaban et al., 2015).

\section{Adhesión}

El flagelo está involucrado en la adhesión a superficies, aunque no es el principal efector de este proceso. Tanto las flagelinas como la proteína cap FliD que forman el filamento, son capaces de adherirse a superficies (Arora et al., 1998). Además de estos 
componentes extracelulares, se encontró que la proteína Flif del cuerpo basal del flagelo también estaría involucrada en este proceso de adhesión (Arora et al., 1998). Se cree que este efecto no se debe a una acción directa de esta proteína, pero es producido gracias a otras proteínas que cumplen esta función que serían excretadas a través de un poro que queda formado gracias a FliF en la membrana bacteriana (Arora et al., 1996).

\section{Freno del filamento para establecer biofilms y dispersión.}

El proceso de adhesión es muy importante para las etapas tempranas de formación de biofilms bacterianos. Para iniciar este proceso, es importante que la bacteria disminuya la velocidad de rotación del flagelo o frene por completo. En $V$. cholerae y $V$. parahaemolyticus, se ha reportado que cuando el flagelo de estas bacterias entra en contacto con una superficie sólida, se produce una señal que provoca el freno del motor, se induce un cambio en el potencial de la membrana y se favorece el proceso de formación de biofilms (Van Dellen et al., 2008; Gode-Potratz et al., 2011). Es por esta razón que se cree que el flagelo sería un mecanosensor.

Esta disminución de la rotación del filamento puede darse por acción de proteínas que interactúan con FliG (anillo C) o MotA (estator) y logran frenar el motor, o a través de la acción del segundo mensajero c-di-GMP. Para liberarse del biofilm, diseminarse y colonizar nuevos nichos, las bacterias deben reactivar la síntesis del sistema flagelar (Guttenplan y Kearns, 2013). En el Capítulo I.5 se abordarán con más detalle estos procesos.

\section{Secreción de sustancias}

El SSTIII encargado de la síntesis del flagelo (descripto previamente) es un sistema muy similar al resto de los inyectisomas o SSTIII no flagelares. Muchas bacterias utilizan este sistema para secretar otras proteínas no flagelares, que suelen ser proteínas efectoras relacionadas con la interacción microorganismo-hospedador (Chaban et al., 2015).

\section{Flagelos dentro del hospedador}

Algunas bacterias patógenas reducen o eliminan por completo la expresión del flagelo dado su efecto inmunogénico (Chaban et al., 2015). Esto lo realizan mediante diversos mecanismos, como la variación de fase (alternando las flagelinas que forman el filamento por otras flagelinas diferentes), la biestabilidad (solo una parte de la población expresa el flagelo), modificación de las flagelinas existentes (alterando la estructura para no mostrar epitopes) o a través de glicosilaciones (modificaciones post-traduccionales de las flagelinas). 


\section{I.4 Características generales de los biofilms}

Las bacterias pueden vivir en vida libre y comportarse de dos maneras muy diferentes: en estado planctónico (movimiento) o en estado sésil (formando biofilms. La formación de biofilms es una característica ancestral e integral de los procariotas y hongos, las cuales fueron desarrolladas para proveer homeostasis en condiciones ambientales extremas y fluctuantes (Hall-Stoodley et al., 2004). Hoy en día se estima que las bacterias que se encuentran en vida libre, gran parte está en estado de biofilms en lugar de encontrarse como células móviles en estado planctónico. Es decir que los biofilms representarían el estado basal en que las células se hallan en su hábitat natural. (Kragh et al., 2016; Flemming et al., 2016).

Los biofilms se definen como comunidades bacterianas rodeadas de una matriz (producida por ellas mismas) unidas de manera reversible a una superficie inerte o biótica, y generalmente, se forman en una interfase sólido-líquido. La unión de bacterias a las superficies les otorga varias ventajas. Las superficies, además de concentrar nutrientes sobre si mismas, actúan como catalizadores de ciertas funciones dado que favorece la proximidad de las células de diferentes especies bacterianas que comparten vías catabólicas. Un ejemplo de ello es la degradación de un herbicida (Linuron), el cual necesita la acción conjunta de tres especies bacterianas para conseguir ser degradado (Flemming et al., 2016).

La matriz está compuesta principalmente de EPS -el cual forma una especie de hidrogel- aunque también podemos encontrar ADN, proteínas, lípidos, agua y minerales. Todos estos componentes se encuentran formando una estructura tridemensional que es característica de cada biofilm. Esta estructura puede ser plana o con forma de hongo dependiendo de la bacteria y los nutrientes disponibles. Dentro de ella podemos encontrar microcolonias de células sésiles que van creciendo alrededor de la matriz y canales de agua que permiten el intercambio de nutrientes y desechos desde o hacia el seno del líquido (Hall-Stoodley et al., 2004).

El crecimiento en biofilms le otorga grandes ventajas a las bacterias que se encuentran en su interior. Dentro de esta estructura, las bacterias se encuentran mejor preparadas para enfrentar una gran variedad de desafíos ambientales como la exposición a luz ultravioleta, toxicidad a metales, exposición a un medio desfavorable (ácido, deshidratación y salinidad) fagocitosis, resistencia a antibióticos y a agentes microbianos. Esta resistencia se debe en parte a la matriz, especialmente al EPS, el cual actúa como una barrera impidiendo la difusión o penetración del agente nocivo. Por ejemplo, en el caso de antibióticos, se produce una dilución de su concentración desde la superficie del biofilm hacia el centro de la estructura. De esta manera, el antibiótico llega a concentraciones subletales e impide la muerte de las bacterias dentro del biofilm (Hall-Stoodley et al., 2004).

Adicionalmente, esta barrera genera un gradiente de concentraciones de oxígeno y de nutrientes, que provoca que la población dentro del biofilm pueda encontrarse en 
diferentes estados fisiológicos. Es decir, algunas bacterias dentro de la estructura se encuentran en estado estacionario, con su metabolismo frenado y por lo tanto, son resistentes a la acción de ciertos agentes antimicrobianos cuyo mecanismo de acción se basa en la disrupción de algún proceso metabólico. Otra hipótesis acerca de la resistencia de estas estructuras se centra en la existencia de bacterias más resistentes que la población general conocidas como bacterias persistentes (Flemming et al., 2016).

\section{Etapas de la formación de biofilms}

El estudio de la formación de esta estructura compleja se puede dividir en etapas secuenciales (Figura 1.8). La primera etapa consiste en una asociación reversible a la superficie, es decir que las bacterias en estado planctónico pueden asociarse a una superficie, pero son capaces de retornar al seno del líquido dado que su maquinaria de movimiento se encuentra intacta (Stoodley et al., 2002). La segunda etapa en cambio, consiste en una adhesión irreversible que continuará con la formación de biofilms. Dentro de los factores involucrados en esta etapa, encontramos proteínas de adhesión a superficies (como por ejemplo adhesinas y pili tipo IV), y producción de EPS que representa el principal componente de la matriz. Si bien estos factores son importantes para el desarrollo de las primeras etapas de la formación de biofilms, la ausencia de alguno de estos factores sólo genera una diminución o retardo de la formación de esta estructura. Esto se debe a las numerosas vías alternativas existentes que permiten que se lleve a cabo las primeras etapas de la formación de biofilms. (Branda et al., 2005).

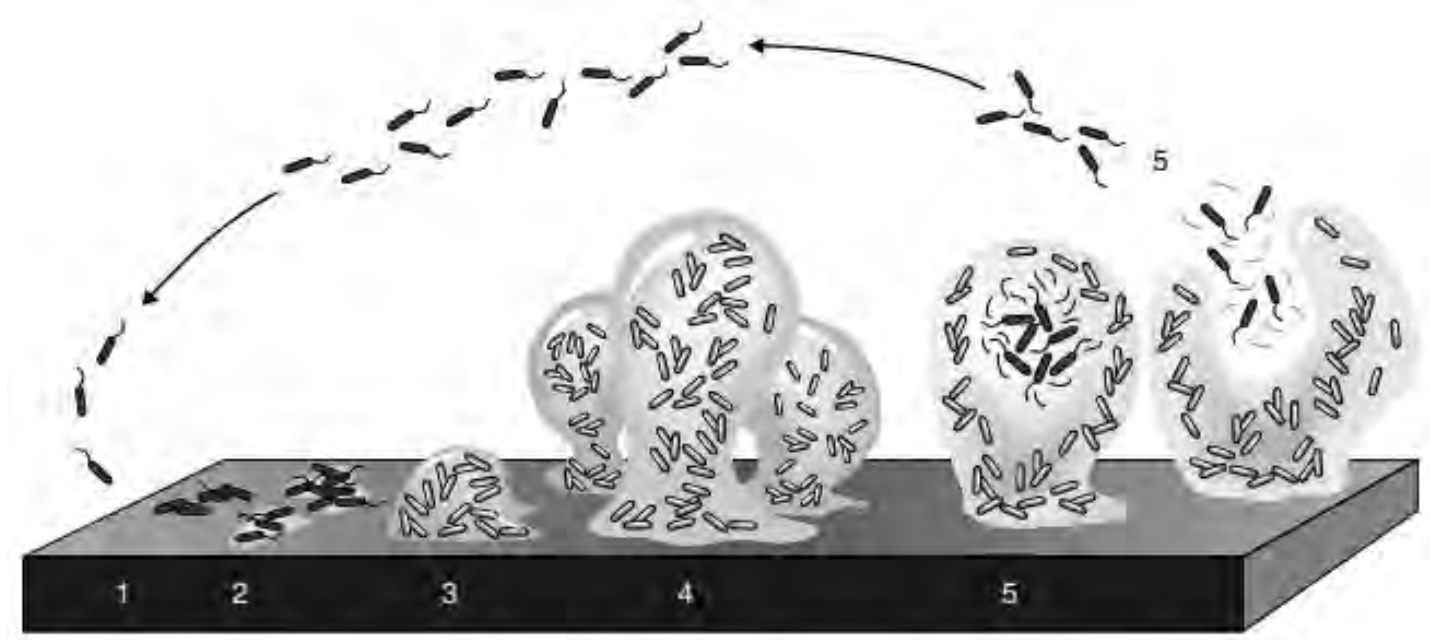

Figura 1.8 - Etapas de la formación de biofilms. La imagen muestra la etapa (1) unión reversible, seguida de unión irreversible (2). Luego comienzan a dividirse, formando microcolonias (3). La estructura de biofilm se continúa desarrollando (con la matriz y los canales de agua) y se alcanza un biofilm maduro (4). Las bacterias pueden liberarse del biofilm y volver al seno del líquido (5). Extraído de Sauer (2003). 
La tercera etapa consiste en la formación de microcolonias sobre la superficie, seguido de la etapa 4 donde continúa el crecimiento junto con la formación de canales de agua y poros dentro de la estructura, alcanzando la maduración del biofilm. La última etapa se caracteriza por la disgregación del biofilm y el recobro de la movilidad bacteriana, que generalmente se produce por un aumento en el esfuerzo de corte (fluid shear) o por escasez de nutrientes, y les permite a las bacterias colonizar nuevos nichos. Este proceso ocurre mediante la degradación enzimática de los EPS o de proteínas de unión a superficie. Existen tres estrategias diferentes de dispersión: células individuales (swarming o seeding), agregados de células liberados de los biofilms (clumping), o dispersión sobre la superficie (el biofilm se desplaza a través de la superficie) (Hall-Stoodley et al., 2004). Las bacterias que abandonan el biofilm, dejan nuevos poros y canales dentro de la estructura (Sauer 2003).

\section{I.5 Regulación mediada por el segundo mensajero c-di-GMP}

Una molécula que es de importancia para la transición entre el estado móvil y el sésil es el segundo mensajero c-di-GMP. El c-di-GMP o ácido bis-(3'5')-diguanilato cíclico, es una molécula de señalización ampliamente distribuida en bacterias involucrada en múltiples procesos celulares, no solo en movilidad y biofilms, sino como son el ciclo celular, activación de virulencia, cambios en la síntesis de macromoléculas, respuesta a estrés, entre otros (Hengge, 2009; Jenal et al., 2017; Dahlstrom y O’Toole 2017).

\section{Síntesis, degradación y proteínas efectoras del c-di-GMP}

La concentración intracelular de esta molécula es entonces fundamental para la regulación de todos estos procesos. La concentración de c-di-GMP varía de acuerdo a la actividad de las proteínas diguanilato ciclasas (DGC), que son capaces de sintetizar esta molécula a partir de dos moléculas de GTP, y la actividad de fosfodiesterasas (PDE), que son capaces de degradarla.

Las DGC se caracterizan por tener un dominio característico denominado GGDEF, aunque también se han encontrados DGC capaces de sintetizar c-di GMP con los dominios AGDEF, GGDEM y SGDEF (este último sólo en eucariotas). Además de este dominio, el $50 \%$ de las DGC poseen un dominio inhibitorio (sitio I) cuya secuencia es RXXD y al unirse el c-di-GMP impide que se continúe sintetizando el segundo mensajero. Las DGC pueden tener además otros dominios sensores (PAS, CACHE, CHASE, MASE y dominios reguladores de respuesta), aunque hasta el momento se encontraron pocos sustratos capaces de inducirlas. Algunos de ellos son el oxígeno, el zinc y la temperatura (Galperin et al., 2001). 
Las PDEs pueden tener dos dominios distintos, dominio EAL o dominio HD-GYP. También existen proteínas que tienen ambos dominios GGDEF y EAL y pueden actuar como DGC y/o PDE.

Dentro de los target del c-di-GMP podemos encontrar diversas familias de proteínas efectoras. Las primeras en ser identificadas fueron las que poseen dominios PilZ, pero luego se han identificado otras proteínas capaces de actuar como proteínas efectoras que poseen dominios EAL y GGDEF degenerados. También se han encontrado proteínas de la familia YajQ que son capaces de responder a este segundo mensajero, al igual que proteínas con actividad ATPasa (que usualmente actúan switches regulatorios) y son capaces de unir c-di-GMP a través de sus dominios AAA+ (Jenal et al., 2017). Además de esa gran variedad de proteínas efectoras el c-di-GMP también puede actuar sobre riboswitchs modificando la formación de biofilms, movilidad, pili y la síntesis y degradación del propio c-di-GMP (Sudarsan et al., 2008). En E. coli se ha reportado también que el c-di-GMP es capaz de modificar el pool de ARN mediante la unión directa con la enzima polinucleótido fosforilasa (PNPasa), la cual forma parte del degradosoma del ARN en esta bacteria (Tuckerman et al., 2011).

\section{Pool de c-di-GMP intracelular}

Algunos microorganismos poseen un gran número de proteínas DGC y PDE (alrededor de 60). Las bacterias de vida libre poseen muchas más proteínas que las que son patógenos intracelulares obligados, probablemente porque se encuentran expuestos a una gran cantidad de señales y ambientes diversos. A pesar de esta gran redundancia de DGC y PDE, se ha encontrado que cada una de ellas, regula solo uno o dos procesos celulares. Esto indicaría que las proteínas efectoras podrían responder de alguna manera al c-di-GMP proveniente de una determinada DGC (Dahlstrom y O’Toole, 2017).

Actualmente, existen dos modelos diferentes que, si bien no logran explicar los comportamientos observados hasta el momento, constituyen un primer paso para lograr desentrañar esta compleja red de señalización (Dahlstrom y O'Toole, 2017).

Uno de ellos consiste en que las DGC se encuentran nutriendo constantemente un pool global de c-di-GMP en la célula, mientras que las PDEs pueden ir disminuyéndolo. A su vez, las proteínas efectoras tendrían diferentes constantes de disociación del c-diGMP y así a igual concentración global de c-di-GMP algunas serían capaces de actuar mientras otras no podrían hacerlo. Pultz y colaboradores (2012) demostraron que la proteína YcgR (proteína efectora involucrada en movilidad) y BcsA (proteína efectora involucrada con la síntesis de celulosa) poseen una diferencia de 40 veces en la afinidad hacia c-di-GMP en S. enterica.

El otro modelo plantea la formación de complejos que contengan proteínas DGC, PDE y proteínas efectoras. De esta manera, las DGC sintetizan c-di-GMP aumentando el pool localizado de este segundo mensajero y produce la activación de la proteína efectora. Mientras tanto, la PDE disminuye la concentración del segundo mensajero 
impidiendo que la molécula difunda hacia otra región de la célula. Linderberg y colaboradores (2013) mostraron que pares de PDE-DGC son capaces de actuar en forma conjunta sobre un pool de c-di-GMP y activar otro par PDE-DCG en E. coli. También determinaron que existe interacción directa del par PDE-DGC y además interacción con la proteína efectora (DGC-PDE-proteína efectora).

\section{I.5.1 Rol fisiológico del c-di-GMP en el desarrollo y morfogénesis bacteriano}

En C. crescentus se ha identificado al c-di-GMP como principal señal para el control del ciclo celular y la morfogénesis diferencial en distintos polos de la bacteria. Es importante recalcar que $C$. crescentus posee una división asimétrica y diferencial, generando dos células, una móvil con un flagelo polar y la otra sésil sin flagelo y con un stalk. Esta diferenciación se da en parte por la acción de una DGC Ilamada PleD, la cual es activada en un polo y desactivada en otro. De esta manera se generan microambientes con distintas concentraciones de este segundo mensajero. Así, el c-diGMP influye tanto en la localización y en la síntesis correcta del flagelo en un polo a través de la defosforilación/degradación del regulador maestro CtrA, como también en el control de la replicación del ADN mediada por esta proteína.

\section{I.5.2 Rol fisiológico del c-di-GMP sobre la movilidad bacteriana y la formación de biofilms}

El c-di-GMP es capaz de modificar la velocidad de rotación del flagelo o incluso frenar el motor. Este efecto le permite a la bacteria cambiar rápidamente su comportamiento para poder adherirse a la superficie de un momento al otro, para luego, a largo plazo, realizar un cambio a nivel de expresión de proteínas flagelares. En las etapas sucesivas, gracias al continuo aumento de c-di-GMP se continúan activando tanto a nivel transcripcional, post-transcripcional o post-traduccional otros procesos como pueden ser la natación cerca de superficies, la expresión de adhesinas y componentes de la matriz necesarios para que se desarrolle el biofilm. Luego cuando la concentración de c-di-GMP comienza a disminuir se desarrollan otros procesos para dispersarse como por ejemplo, la activación de proteasas para degradar las adhesinas y poder liberarse del biofilm.

Esta relación del c-di-GMP sobre la movilidad y la formación de biofilms resulta muy interesante para entender cómo las bacterias son capaces de realizar el switch entre estos dos estilos de vida diferentes. En la Figura 1.9 se muestran diferentes efectos del c-di-GMP durante la formación de biofilms. 
Freno del motor Eyección del flagelo

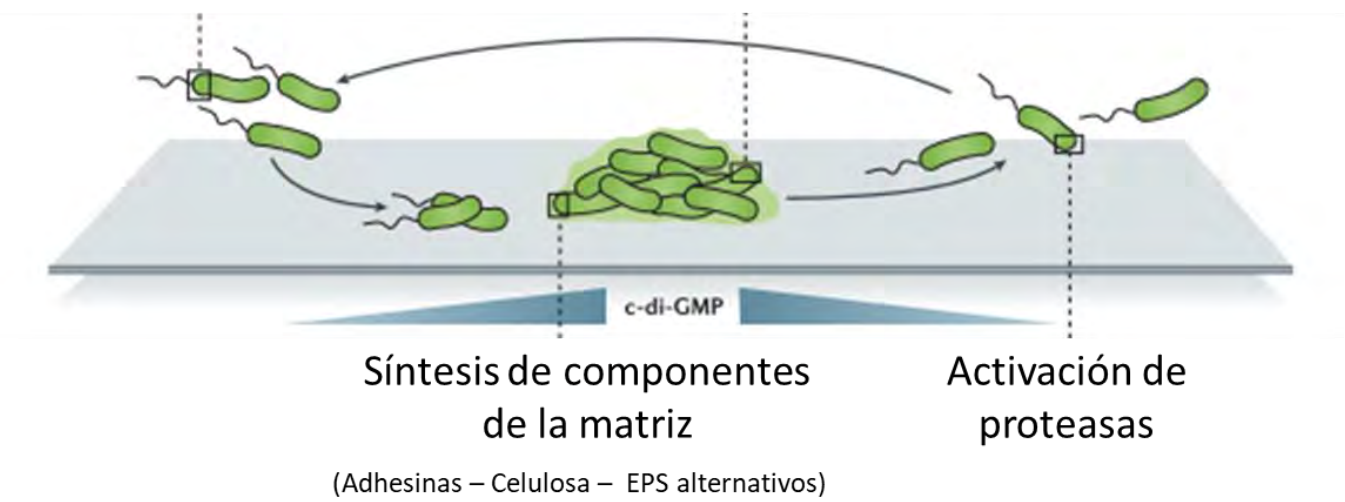

Figura I.9 - Efecto del c-di-GMP durante la formación de biofilms. En las primeras etapas de formación de biofilms, el motor del flagelo disminuye su velocidad para permitir la adhesión a la superficie. Luego, se sintetizan componentes necesarios para la formación de biofilms como son adhesinas, celulosa y EPS alternativos, y también se produce la eyección del flagelo. En la etapa de dispersión, se activan proteasas que desprenden adhesinas que permiten la liberación de las células. Extraída y modificada de Jenal y col. (2017).

\section{Velocidad de rotación del flagelo}

En E. coli por ejemplo, se ha encontrado que la proteína $Y c g R$, que es una proteína efectora con dominio PilZ, es capaz de regular la velocidad y dirección del flagelo mediante la interacción con las proteínas FliGM que conforman el anillo $\mathrm{C}$ del cuerpo basal del flagelo (Paul et al., 2010). En B. subtilis también se ha encontrado una proteína denominada EpsE, la cual se encuentra asociada más al estado sésil, pero que también actúa sobre el anillo $\mathrm{C}$, aunque en este caso provoca el desacople del estator y del rotor (Blair et al., 2008). Esta diferencia en la acción de YcgR y EpsE podría ser debido a que ambas proteínas funcionan en momentos diferentes. Por un lado, YcgR parecería ser necesaria en las etapas iniciales de la formación de biofilms, disminuyendo la velocidad del flagelo y de esta manera permitiendo que la bacteria se adhiera a la superficie. En cambio, EpsE actúa una vez que ya se ha comenzado la síntesis de EPS y la formación del biofilm, por lo que la rotación del mismo no es necesaria.

En C. crescentus, DgrA es una proteína efectora que une c-di-GMP y también produce el freno del flagelo mediante FliL. Esta proteína sería importante para la estabilidad del flagelo cuando la bacteria percibe un aumento de torque, y actúa junto con MotB modificando el canal mediante el cual pasan los $\mathrm{H}^{+}$(Suaste-Olmos et al., 2010). Producto del contacto de la bacteria con una superficie DgrA actuaría sobre FliL impidiendo la rotación del flagelo (Belas, 2014). 


\section{Eyección del flagelo}

En C. crescentus se ha determinado que la ausencia de una DGC denominada PleD, impide la eyección del flagelo durante el transcurso del ciclo celular. Esta proteína de alguna manera favorecería la degradación de FliF (anillo MS), lo que permite el desprendimiento del flagelo. FliL también sería partícipe de este proceso, aunque el mecanismo aún no se conoce (Aldridge y Jenal, 1999).

\section{Regulación de factores transcripcionales}

En otras bacterias, se ha detectado una relación directa entre los reguladores flagelares y el c-di-GMP. Uno de ellos es FleQ en $P$. aeruginosa. En este sistema se ha descripto que el c-di-GMP es capaz de unirse al sitio AAA+ de FleQ y de esta manera modificar su actividad inhibiendo la formación del flagelo y favoreciendo la formación de EPS (Baraquet et al., 2012).

En C. crescentus se ha detectado diferentes niveles de acción del c-di-GMP sobre el regulador transcripcional CtrA. Uno de ellos proviene de la capacidad de CckA (una proteína del sistema de transferencia de fosfato) de unir c-di-GMP en su dominio AAAt. De esta manera, CckA promueve la defosforilación de CtrA mediante la reversión de la transferencia de fosfato, y por lo tanto inactivación de CtrA. Además de la inactivación de CtrA, la proteína es degradada en presencia de c-di-GMP. PopA es capaz de unir este segundo mensajero en el sitio I, y secuestrar a CtrA para su degradación mediante la proteasa ClpXP (Ozaki et al., 2014). Dada la acción de CtrA como regulador maestro del flagelo y la regulación del ciclo celular, el c-di-GMP también estaría coordinando estos dos procesos.

En $V$. cholerae, el factor de transcripción VpsT controla la producción de componentes de la matriz extracelular, la movilidad y la formación de biofilms. La unión del c-di-GMP a VpsT provoca la oligomerización de esta proteína, lo que permite la expresión de los genes responsables de la formación de polisacáridos (Krasteva et al., 2010)

\section{Sistemas de exportación}

Muchas proteínas involucradas en los sistemas de exportación poseen también dominios AAAt. En $V$. cholerae la proteína ATPasa que forma el pili es capaz de unir cdi-GMP, y en $P$. aeruginosa proteínas ATPasas del SSTVI y SSTIII no son activas en presencia del segundo mensajero (Moscoso et al., 2011) Incluso Trampari y colaboradores (2015) han demostrado que la proteína Flil (que forma parte del SSTIII del flagelo) se une a este segundo mensajero y su actividad responde a los niveles de cdi-GMP.

\section{Dispersión del biofilm}

LapD de $P$. fluorescens, es un ejemplo de proteína efectora con ambos dominios GGDEF y EAL degenerados. En este caso, la unión del c-di-GMP al dominio EAL de LapD controla la formación de biopelículas a través de una proteasa LapG, la cual degrada la adhesina LapA y la bacteria es capaz de liberarse del biofilm (Newell et al., 2011). 


\section{I.6 B. diazoefficiens y la movilidad}

Una de las cepas modelo más estudiadas, capaz de realizar la FBN con soja, es Bradyrhizobium diazoefficiens (antes B. japonicum) USDA 110. Esta $\alpha$-Proteobacteria posee un cromosoma circular de 9,5 Mpb que fue secuenciado hace 16 años (Kaneko et al., 2002) y no presenta plásmidos adicionales.

A diferencia de todas las demás especies de rizobios e inclusive de otras especies del mismo género, $B$. diazoefficiens posee dos sistemas flagelares independientes. En la Figura 1.10 se muestra una fotografía de esta bacteria vista al microscopio electrónico, en donde se observan distintos filamentos unidos a ella, uno grueso semienrrollado de $2,8 \mu \mathrm{m}$ de longitud de la curvatura y $22 \mathrm{~nm}$ de ancho correspondiente al sistema subpolar, y varios filamentos finos más enrulados de 0,7 $\mu \mathrm{m}$ longitud de curvatura y $12 \mathrm{~nm}$ de ancho, correspondientes al sistema lateral (Kanbe et al., 2007; Althabegoiti et al., 2008).

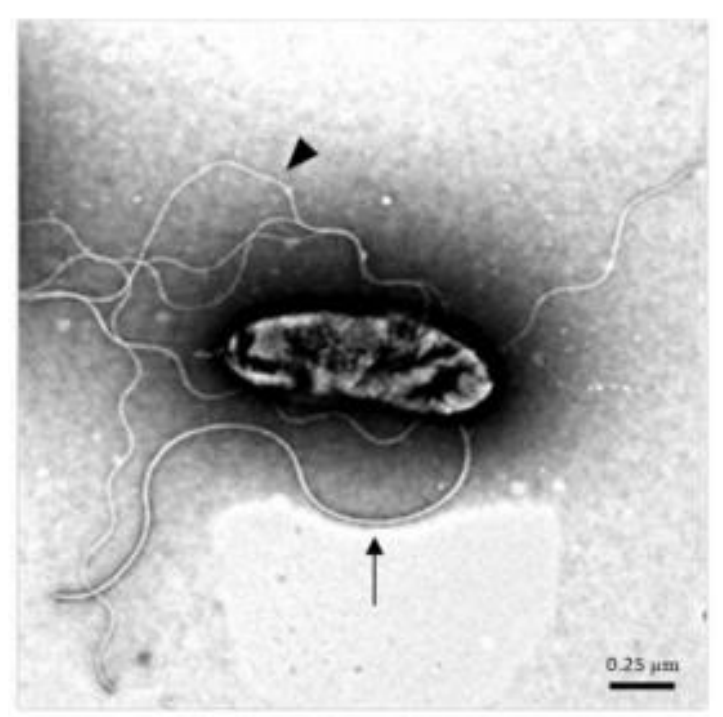

Figura 1.10 - Micrografía electrónica de transmisión de $B$. diazoefficiens USDA 110 crecida en medio líquido AG. La flecha larga señala el flagelo monótrico subpolar y la cabeza de flecha los flagelos perítricos laterales. Extraída de Quelas y col. (2016a).

Ambos sistemas flagelares aportan sustancialmente al movimiento de natación, aunque poseen ciertas características distintivas. Por un lado, el flagelo subpolar de $B$. diazoefficiens es único, se expresa tanto en medios líquidos como en medios semisólidos, favorece el nado de la bacteria en línea recta y se encuentra involucrado en los procesos de adhesión y quimiotaxis hacia glutamato y succinato (Quelas et al., 2016a). Además, este flagelo cobra importancia durante las etapas de la interacción simbiótica con plantas de soja, debido a que las cepas que poseen sólo el flagelo subpolar son capaces de competir mejor por la ocupación de nódulos, tanto a capacidad de campo como en inundación, comparado con la cepa que expresa ambos flagelos. (Althabegoiti et al., 2011). 
El sistema lateral está compuesto por varios flagelos, cuyo número es variable y todavía no se sabe fehacientemente, aunque se calculan unos 5-7 flagelos por célula (Quelas, comunicación personal). A diferencia del sistema subpolar, su expresión depende de varios factores. Por ejemplo, el flagelo lateral es expresado en medios líquidos en presencia de arabinosa, pero no en presencia de manitol (Covelli et al, 2013; Figura 1.11). La falta de expresión del sistema lateral en medios líquidos con manitol puede ser revertida cuando la bacteria se encuentra creciendo con la misma fuente de carbono, pero en un medio semisólido o viscoso (Quelas et al., 2016a; Figura I.11). Es decir, existe una señal (o varias) que induce/n al sistema de flagelos laterales cuando el medio es viscoso o cuando existen obstáculos (el entramado del agar en una placa de natación).

A

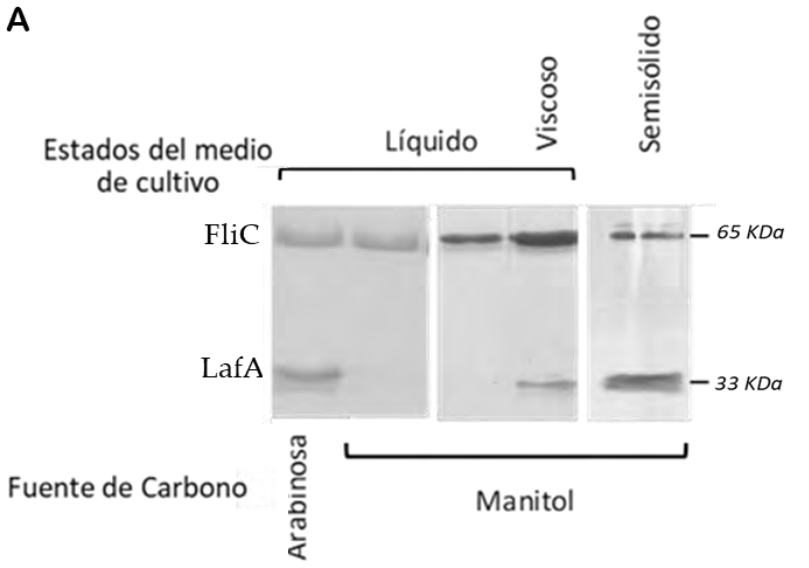

B

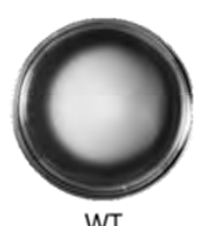

WT

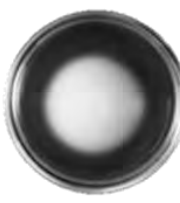

$\Delta$ flic

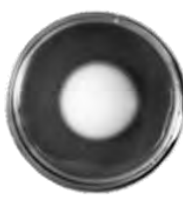

$\Delta$ lafA

Figura I.11 - Perfil de flagelinas de $B$. diazoefficiens en distintas condiciones de cultivo (A) y ensayo de movilidad en agar semisólido (B). A. Las proteínas de $64 \mathrm{kDa}$ representan las cuatro flagelinas subpolares (FliC) que forman el filamento del flagelo subpolar y las proteínas de $33 \mathrm{kDa}$ representan las dos flagelinas (LafA) que constituyen el filamento de los flagelos laterales de $B$. diazoefficiens. La extracción de flagelinas se realizó a partir de medios líquidos con arabinosa o manitol como únicas fuentes de carbono, en medio líquido viscoso (con manitol como fuente de carbono y en presencia de un agente viscosante) y a partir de placas de natación en agar semisólido en medios con manitol como única fuente de carbono. B. Ensayo de natación en agar semisólido de la cepa wild-type (WT), y las cepas mutantes (Capítulo II.3.9). Se muestran fotos presentativas de cada cepa en placas de Petri a los 18 días luego de la inoculación.

Es preciso señalar también que, a pesar de que ambos sistemas flagelares aportan igualitariamente al movimiento de natación en medios agarizados (Althabegoiti et al., 2011), el sistema subpolar es el que más aporta a la velocidad en medios líquidos (Figura I,11-B). Así, la cepa de B. diazoefficiens USDA 110 que solo posee flagelo subpolar, nada a una velocidad promedio de $26,9 \pm 2,0 \mu \mathrm{m} / \mathrm{s}$, mientras que la cepa que solo posee flagelos laterales, lo hace a 17,2 $\pm 0,8 \mu \mathrm{m} / \mathrm{s}$ (Quelas et al., 2016a).

La síntesis y movilidad de los flagelos involucra la transcripción y traducción de numerosas proteínas, y el gasto de una gran cantidad de energía para poder moverlos. A pesar de ello, y a diferencia de la mayoría de las especies con sistemas flagelares duales, en $B$. diazoefficiens USDA 110 pueden coexistir ambos sistemas en medios líquidos (Quelas et al., 2016a). En otras especies con sistemas duales, como Azospirillum, Aeromonas, Rhodospirillum o Vibrio, por citar cuatro ejemplos, un 
sistema flagelar es utilizado para el swimming, mientras el otro es utilizado para el swarming (McCarter, 2004).

Nuestro grupo de trabajo ha podido determinar que una cepa con movilidad aumentada fue capaz de mejorar los rendimientos de los cultivos de soja (Althabegoiti et al., 2008). En relación con ello, dicha cepa presenta desregulada la síntesis de flagelos laterales, ya que la misma es capaz de sintetizarlos (junto con el flagelo subpolar) en medios con manitol como única fuente de carbono (Althabegoiti et al., 2008). Ello indicaría que se podrían obtener mejoras en los inoculantes comerciales si mejoramos la capacidad de natación o el estado flagelar de una cepa. Para ello, entendemos que es preciso conocer y estudiar en profundidad los diferentes factores que afectan a la síntesis de los flagelos y su regulación génica. En este sentido, recientemente hemos logrado determinar la cascada regulatoria del sistema lateral de B. diazoefficiens USDA 110 (Mongiardini et al., 2017). Este sistema parece asemejarse a la cascada regulatoria descripta en $E$. meliloti y $B$. melitensis, siendo LafR el regulador maestro de la síntesis (homólogo a Rem de E. meliloti); y FlaF $F_{L}-F_{b} T_{L}$, los reguladores de clase II.

La cepa con mayor movilidad presenta además mayor quimiotaxis, y como mencionamos anteriormente, el sistema subpolar sería responsable de este proceso en B. diazoefficiens (Althabegoiti et al., 2008; Quelas et al., 2016a). La regulación génica del flagelo subpolar, por el contrario, aún no ha sido determinada, y representa el principal objetivo de este trabajo de Tesis. 


\section{Resumen y Objetivos}

La capacidad de moverse es una propiedad muy importante para cualquier especie bacteriana. Esta característica le permite colonizar nuevos nichos, alejarse de sustancias nocivas y acercarse en busca de nuevos nutrientes, entre otras. Particularmente, $B$. diazoefficiens es un rizobio que puede hallarse en los suelos (naturales y antrópicos) y vivir en vida libre -estado planctónico (movilidad) o estado sésil (formando biofilms)- o interaccionando con su par simbiótico. Para buscar y colonizar plantas de soja, una bacteria móvil debe desplazarse hacia sus raíces, ser capaz de adherirse y formar microcolonias, infectar las raíces más pequeñas y diferenciarse a bacteroide dentro de los nódulos. Este cambio radical entre los diferentes estadíos se debe a un gran cambio en la transcripción genética y expresión proteica en cada uno de ellos (Jiménez-Guerrero et al., 2017).

B. diazoefficiens utiliza dos sistemas de flagelos (lateral y subpolar) que le permiten desplazarse. La síntesis flagelar es un proceso que se encuentra altamente regulado dado la gran cantidad de proteínas necesarias y el alto costo energético que implica su formación (Macnab, 2003). En general, la síntesis de los flagelos ocurre en etapas escalonadas, que, dependiendo del microorganismo, puede ser dividida en tres o cuatro, siendo cada una de ellas desencadenada por una señal específica (Figura I.7). A través de estudios bioinformáticos, hemos podido asignar dos modelos de regulación diferentes a cada uno de los sistemas flagelares de B. diazoefficiens. Para los flagelos laterales, nuestro grupo de investigación demostró, mediante estrategias de mutagénesis dirigida y ensayos de PCR cuantitativa en tiempo real (qRT-PCR) que el

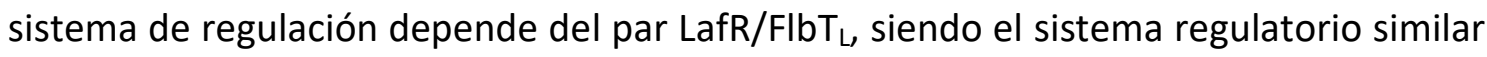
al descripto en E. meliloti.

Por el contrario, la regulación de la síntesis del sistema subpolar, el cual es necesario en los procesos de natación lineal, adhesión a superficies y quimiotaxis, aún no ha sido estudiado en este microorganismo.

\section{Objetivo general}

En este trabajo de Tesis nos planteamos como objetivo principal la caracterización de la cascada regulatoria de la síntesis del flagelo subpolar de $B$. diazoefficiens USDA 110 y las señales involucradas en este proceso.

\section{Objetivos específicos:}

1) Caracterización genómica detallada de los genes que codifican el flagelo subpolar mediante técnicas bioinformáticas. 
2) Identificar y caracterizar los genes relacionados con la regulación de la síntesis del flagelo subpolar de B. diazoefficiens USDA 110.

3) Evaluar posibles señales involucradas en el control de la síntesis del flagelo subpolar.

4) Evaluar el rol del c-di-GMP sobre la regulación del flagelo subpolar de $B$. diazoefficiens USDA 110. 
Capítulo II: Materiales y Métodos 



\section{II.1 Herramientas bioinformáticas}

\section{II.1.1 Bases de datos}

Para obtener las secuencias nucleotídicas y aminoacídicas de los genes y proteínas analizadas en este trabajo se utilizaron las siguientes bases de datos: IMG (https://img.jgi.doe.gov/), Uniprot (https://www.uniprot.org/), microbes online (http://www.microbesonline.org/), PubMed (https://www.ncbi.nlm.nih.gov/pubmed) y RhizoBase (http://genome.annotation.jp/rhizobase).

\section{II.1.2 Búsquedas de secuencias homólogas y dominios conservados}

Para la búsqueda de proteínas con secuencias homólogas se utilizó el servidor Blastp (https://blast.ncbi.nlm.nih.gov/Blast.cgi). Para la búsqueda de motivos específicos de ADN en el genoma de $B$. diazoefficiens o en regiones 5 'no traducidas se utilizó el servidor MEME suite (http://meme-suite.org/). Los dominios proteicos fueron identificados a través de los servidores Pfam (http://pfam.xfam.org/) y SMART (https://smart.embl.de/).

\section{II.1.3 Alineamientos y árboles filogenéticos}

Los alineamientos de secuencia fueron realizados en los servidores Clustal Omega (https://www.ebi.ac.uk/Tools/msa/clustalo/), T-Coffee (http://tcoffee.crg.cat/apps/ tcoffee/do:regular) y MUSCLE (https://www.ebi.ac.uk/Tools/msa/muscle/). El formato de los alineamientos en escala de negros y grises fue realizado con el servidor Boxshade (http://www.ch.embnet.org/software/BOX_form.html).

Los árboles se construyeron en MEGA X utilizando el método de Maximum Likelihood a partir de alineamientos obtenidos calculados con MUSCLE. En todos los casos el soporte de las ramas se calculó mediante el método de bootstrap con 1000 réplicas.

\section{II.1.4 Modelado de regiones 5'no traducidas}

Para realizar los modelados de las regiones 5'UTR de las flagelinas subpolares se tomaron las regiones 5'UTR a partir de los datos de transcriptómica (Cuklina et al., 2016) y se sumaron 51 nucleótidos a partir del codón de inicio de manera similar a la realizada por Anderson y Gober (2000). Los modelados se realizaron con el servidor mfold (http://unafold.rna.albany.edu//?q=mfold/RNA-Folding-Form). 


\section{II.2 Cepas y plásmidos utilizados}

Tabla II.1 - Cepas utilizadas en este trabajo.

\begin{tabular}{|c|c|c|}
\hline Cepas & Características & Referencia \\
\hline \multicolumn{3}{|l|}{ E. coli } \\
\hline $\mathrm{DH} 5 \alpha$ & recA, $\Delta / a c \cup 169$, Ф80d/acZ $\Delta \mathrm{M} 15$ & Bethesda Res. Lab \\
\hline S17-1 & E. coli 294 RP4-2-Tc::Mu-Km::Tn7 & Simon et al., 1983 \\
\hline
\end{tabular}

\section{B. diazoefficiens}

USDA 110

Cepa WT $\mathrm{Cm}^{R}$

$\Delta$ flic

$\Delta l a f A$

$\Delta$ lafA- $\Delta$ fliC

$\Delta f l b D$

flix::Km

$\Delta f l b D-f l i X:: \mathrm{Km}$

$\Delta f l a F$

$f l b T:: \mathrm{Km}$

$\Delta f l a F-f l b T:: \mathrm{Km}$

$\Delta$ flaF- $\Delta$ lafA

$\Delta f l a F-f l b T:: K m-\Delta l a f A$

$\Delta m o t B_{1}$

$\Delta m o t B_{1}-\Delta f l i C$

$f l g D_{3}:: \mathrm{Km}$
Cepa derivada de USDA 110. Deleción de los cuatro genes que codifican flagelinas subpolares (blr58436) por inserción del cassette $\mathrm{Km} . \mathrm{Km}^{R} \mathrm{Cm}^{R}$ Cepa derivada de USDA 110. Deleción de los dos genes que codifican flagelinas laterales (blr6865-6) por inserción del omegón $s m-s p . S m^{R} S p^{R} C m^{R}$

Cepa derivada de $\Delta$ lafA. Deleción de los cuatro genes que codifican flagelinas subpolares y los dos de las flagelinas laterales. $S m^{R} S p^{R} \mathrm{Km}^{R} \mathrm{Cm}^{R}$

Cepa derivada de USDA 110. Deleción de un fragmento de blr7003. $\mathrm{Cm}^{R}$

Cepa derivada de USDA 110. Interrupción con cassette $\mathrm{Km}$ en bll5837. $\mathrm{Km}^{R} \mathrm{Cm}^{R}$

Cepa derivada de $\triangle f l b D$. Interrupción con cassette $\mathrm{Km}$ en bll5837. $\mathrm{Km}^{R} \mathrm{Cm}^{R}$

Cepa derivada de USDA 110. Deleción de un fragmento de bll5842. $\mathrm{Cm}^{R}$

Cepa derivada de USDA 110. Interrupción con cassette $\mathrm{Km}$ en bll5847. $\mathrm{Km}^{R} \mathrm{Cm}^{R}$

Cepa derivada de $\Delta$ flaF. Interrupción con cassette $\mathrm{Km}$ en blr5847. $\mathrm{Km}^{R} \mathrm{Cm}^{R}$

Cepa derivada de $\triangle$ lafA. Deleción de un fragmento de bll5842. $S m^{R} S p^{R} C m^{R}$

Cepa derivada de $\triangle$ flaF- $\Delta$ lafA. Interrupción con cassette $\mathrm{Km}$ en bll5847. $S m^{R} S p^{R} \mathrm{Km}^{R} \mathrm{Cm}^{R}$

Cepa derivada de USDA 110. Deleción de un fragmento de bll1510. $\mathrm{Cm}^{R}$

Cepa derivada de $\Delta$ flic. Deleción de un fragmento de bll1510. $\mathrm{Cm}^{R}$

Cepa derivada de USDA 110. Interrupción con
Departamento de

Agricultura de

Estados Unidos

(USDA)

Mengucci et al., manuscrito en redacción

Mengucci et al., manuscrito en redacción Mengucci et al., manuscrito en redacción

Esta Tesis

Esta Tesis

Esta Tesis

Esta Tesis

Esta Tesis

Esta Tesis

Esta Tesis

Esta Tesis

Esta Tesis

Esta Tesis

Esta Tesis 
cassette $\mathrm{km}$ en blr3699. $\mathrm{Km}^{R} \mathrm{Cm}^{R}$

1502::Gm

$\Delta 1500$

$B d-p F A J$

$B d-p F A J:: c t r A$

$B d$-pFAJ::fliX

fliX::Km-

$p F A J$

fliX::Km-pFAJ::fliX

$B d-p F A J:: t p b B$

Bd-pFAJ::pleD*

$B d-p B 3$

$B d-p B 3:: f l b D$

$\Delta f l b D-p B 3$

$\Delta f l b D-p B 3:: f l b D$

$B d-s p c 4$

$\Delta r p o N_{1}$

$\Delta \operatorname{rpoN}_{2}$

$\Delta r p o N_{1}-\Delta r p o N_{2}$
Cepa derivada de USDA 110. Interrupción con cassette $\mathrm{gm}$ en bll1502. $\mathrm{Gm}^{R} \mathrm{Cm}^{R}$

Cepa derivada de USDA 110. Deleción de un fragmento de bll1500. $\mathrm{Cm}^{R}$

Cepa derivada de USDA 110. Porta el plásmido pFAJ1708. $T c^{R} \mathrm{Cm}^{R}$

Cepa derivada de USDA 110. Porta el plásmido pFAJ::2200. $T c^{R} \mathrm{Cm}^{R}$

Cepa derivada de USDA 110. Porta el plásmido pFAJ::5837. $T c^{R} \mathrm{Cm}^{R}$

Cepa derivada de fliX::Km. Porta el plásmido pFAJ1708. $T c^{R} \mathrm{Cm}^{R}$

Cepa derivada de fliX::Km. Porta el plásmido pFAJ::5837. $T c^{R} \mathrm{Cm}^{R}$

Cepa derivada de USDA 110. Porta el plásmido pFAJ::tpbB. $T c^{R} \mathrm{Cm}^{R}$

Cepa derivada de USDA 110. Porta el plásmido pFAJ::pleD*. $T c^{R} C m^{R}$

Cepa derivada de USDA 110. Porta el plásmido pBBR1MCS3. $\mathrm{Tc}^{R} \mathrm{Cm}^{R}$

Cepa derivada de USDA 110. Porta el plásmido pB3::7003. $\mathrm{Tc}^{R} \mathrm{Cm}^{R}$

Cepa derivada de $\triangle f l b D$. Porta el plásmido pBBR1MCS3. $\mathrm{Tc}^{R} \mathrm{Cm}^{R}$

Cepa derivada de $\triangle f l b D$. Porta el plásmido pBBR1MCS3::flbD. $T c^{R} \mathrm{Cm}^{R}$

Cepa derivada de USDA 110 resistente a $S p S p^{R} \mathrm{Cm}^{R}$

Cepa derivada de Bd-spc4. Los autores la denominaron N50. Interrupción de blr1883 con cassette $\mathrm{Km} . \mathrm{Km}^{R} \mathrm{Sp}^{R} \mathrm{Cm}^{R}$

Cepa derivada de Bd-spc4. Los autores la denominaron N63. Interrupción de blr0723 con cassette $\mathrm{Km} . \mathrm{Km}^{R} \mathrm{Sp}^{R} \mathrm{Cm}^{R}$

Cepa derivada de $B d$-spc4. Los autores la denominaron N50-97. Interrupción de blr1883 (con cassette $\mathrm{Km}$ ) y blr0723 (con cassette $\mathrm{sm}$ ). $\mathrm{Km}^{R} \mathrm{Sm}^{R}$ $S p^{R} \mathrm{Cm}^{R}$
Esta Tesis

Trabajo final de licenciatura

Carolina Dardis

Esta Tesis

Esta Tesis

Esta Tesis

Esta Tesis

Esta Tesis

Esta Tesis

Esta Tesis

Esta Tesis

Esta Tesis

Esta Tesis

Esta tesis

Regensburger y Hennecke, 1983

Kullik et al., 1991

Kullik et al.,1991

Kullik et al.,1991 
Tabla II.2 - Plásmidos utilizados en este trabajo.

Plásmidos

Características

\section{Vectores de entrada}

pBlueScriptSK(+)

pBS::2200Dw

pBS::5837

pBS::1510

pUC4K

pJBTc19::pleD*
$A p^{R} / a c Z \alpha$

Derivado de pBlueScriptSK(+) conteniendo la región

Dw de bll2200 (ctrA). Ap ${ }^{R}$

Derivado de pBlueScriptSK(+) conteniendo bll5837 (fliX) completo. $A p^{R}$

Derivado de pBlueScriptSK(+) conteniendo bll1510 completo $\left(\operatorname{mot}_{1}\right) \cdot A p^{R}$

Fuente del gen $n p t / l$ de resistencia a Km. $\mathrm{Km}^{R}$

Fuente del gen ple $D^{*}$ de $C$. crescentus. $T c^{R}$
Referencia

Stratagene, La

Jolla, CA, USA

Esta Tesis

Esta Tesis

Esta Tesis

Vieira y Messing, 1991

Pérez-Mendoza

et al., 2014

\section{Vectores suicidas en $B$. diazoefficiens}

pG18mob2

$p G:: 2200 U p$

pG::2200UpDw

pG::2200UpDw::Km

pG::5808

pG::5808::Km

pG::5837

pG::5837::Km

pG::3699

pG::3699::Km

pMJA10

pK18mobsacB

pKsacB::7003

pKsacB:: $\triangle 7003$

\section{$\mathrm{Mob}^{+} \mathrm{Gm}^{R}$ lacZa}

Derivado de $p G 18 m o b 2$ conteniendo la región Up de bll2200 (ctrA). $G m^{R}$

Derivado de $p G:: 2200 U p$ conteniendo ambos extremos (UpDw) de bll2200. $G m^{R}$

Derivado de $p G:: 2200 U p D w$ conteniendo ambos extremos (UpDw) de bll2200 interrumpido por inserción del cassette $\mathrm{Km} . \mathrm{Gm}^{R} \mathrm{Km}^{R}$

Derivado de $p G 18 m o b 2$ conteniendo un fragmento de bll5808 (cckA). $G m^{R}$

Derivado de $p G:: 5808$ conteniendo un fragmento de bll5808 interrumpido por inserción del cassette $\mathrm{Km}$. $\mathrm{Gm}^{R} \mathrm{Km}^{R}$

Derivado de pG18mob2 conteniendo bll5837 (fliX). $G m^{R}$

Derivado de $p G:: 5837$ conteniendo bll5837 interrumpido por inserción del cassette $\mathrm{Km} . \mathrm{Gm}^{R} \mathrm{Km}^{R}$ Derivado de $p G 18 m o b 2$ conteniendo blr3699 $\left(\mathrm{flg}_{3}\right)$. $G m^{R}$

Derivado de $p G:: 3699$ conteniendo blr3699 interrumpido por inserción del cassette $\mathrm{Km} . \mathrm{Gm}^{R} \mathrm{Km}^{R}$ Derivado de pG18mob2 llevando las regiones 5'y $3^{\prime}$ de flic1234 interrumpidas con el cassette $\mathrm{Km} . \mathrm{Gm}^{R}$ $\mathrm{Km}^{R}$

$\mathrm{Mob}^{+} \mathrm{Km}^{R}$ lacZa SacB

Derivado de pK18mobsacB conteniendo un fragmento de blr7003 (flbD). $\mathrm{Km}^{R}$

Derivado de pKsacB::7003 conteniendo blr7003
Kirchner y Tauch, 2003

Esta Tesis

Esta Tesis

Esta Tesis

Esta Tesis

Esta Tesis

Esta Tesis

Esta Tesis

Esta Tesis

Esta Tesis

Althabegoiti, 2012 Tesis

doctoral

Schäfer et al., 1994

Esta Tesis

Esta Tesis 


\begin{tabular}{|c|c|c|}
\hline & mutado para deleción limpia. $\mathrm{Km}^{R}$ & \\
\hline pKsacB::7003DxA(2) & $\begin{array}{l}\text { Derivado de pK18mobsacB conteniendo blr7003 } \\
(f l b D) \text { mutado para sustitución de aminoácido }\left(D_{52} A\right) \text {. } \\
\mathrm{Km}^{R}\end{array}$ & Esta Tesis \\
\hline pKsacB::5842 & $\begin{array}{l}\text { Derivado de pK18mobsacB conteniendo bll5842 } \\
\text { (flaF) mutado para deleción limpia. } \mathrm{Km}^{R}\end{array}$ & Esta Tesis \\
\hline pKsacB::1510 & $\begin{array}{l}\text { Derivado de pK18mobsacB conteniendo un } \\
\text { fragmento de bll1510 }\left(\operatorname{mot}_{1}\right) \cdot \mathrm{Km}^{R}\end{array}$ & Esta Tesis \\
\hline pKsacB:: $\triangle 1510$ & $\begin{array}{l}\text { Derivado de pKsacB::1510 conteniendo bll1510 } \\
\text { mutado para deleción limpia. } \mathrm{Km}^{R}\end{array}$ & Esta Tesis \\
\hline pKsacB::1502::Gm & $\begin{array}{l}\text { Derivado de pK18mobsacB conteniendo bll1502 } \\
\text { interrumpido por inserción del cassette } \mathrm{Km} . \mathrm{Km}^{R} \mathrm{Gm}^{R}\end{array}$ & $\begin{array}{l}\text { Trabajo final de } \\
\text { licenciatura } \\
\text { Ballarre } 2013\end{array}$ \\
\hline $\begin{array}{l}\text { pG18mobLK::flbT }:: \text { K } \\
\mathrm{m}\end{array}$ & $\begin{array}{l}\text { Derivado de pG18mobLK conteniendo bll5847 } \\
\text { interrumpido por inserción del cassette } \mathrm{Km} \text {. }\end{array}$ & $\begin{array}{l}\text { Quelas, sin } \\
\text { publicar }\end{array}$ \\
\hline ctores replice & B. diazoefficiens & \\
\hline pBBR1MCS3 & $T c^{R}$ & $\begin{array}{l}\text { Kovach et } \\
\text { al., } 1995\end{array}$ \\
\hline pB3::7003 & $\begin{array}{l}\text { Derivado de pBBR1MCS3 conteniendo deblr7003 } \\
(f \mid b D) \text { completo. } T c^{R}\end{array}$ & Esta Tesis \\
\hline pFAJ1708 & $A p^{R} T c^{R}$ & $\begin{array}{l}\text { Dombretch et al., } \\
2001\end{array}$ \\
\hline pFAJ::2200 & $\begin{array}{l}\text { Derivado de pFAJ1708 conteniendo bll2200completo } \\
\text { (ctrA). } A p^{R} T c^{R}\end{array}$ & Esta Tesis \\
\hline pFAJ::5837 & $\begin{array}{l}\text { Derivado de pFAJ1708 conteniendo bll5837completo } \\
(f l i X) . A p^{R} T c^{R}\end{array}$ & Esta Tesis \\
\hline pFAJ::pleD* & $\begin{array}{l}\text { Derivado de pFAJ1708 conteniendo pleD* de } C \text {. } \\
\text { crescentus. } A p^{R} T c^{R}\end{array}$ & Esta Tesis \\
\hline$p F A J:: t p b B$ & $\begin{array}{l}\text { Derivado de pFAJ1708 conteniendo tpbB de } P \text {. } \\
\text { aeruginosa. } A p^{R} T c^{R}\end{array}$ & Esta Tesis \\
\hline
\end{tabular}

\section{II.3 Procedimientos microbiológicos}

\section{II.3.1 Medios de cultivos para microorganismos}

Las cepas de $E$. coli se cultivaron de forma rutinaria a $37^{\circ} \mathrm{C}$, tanto en medio sólido como líquido (180 rpm), utilizando el medio Luria-Bertani (LB), cuya composición es la siguiente (Sambroock, 1989):

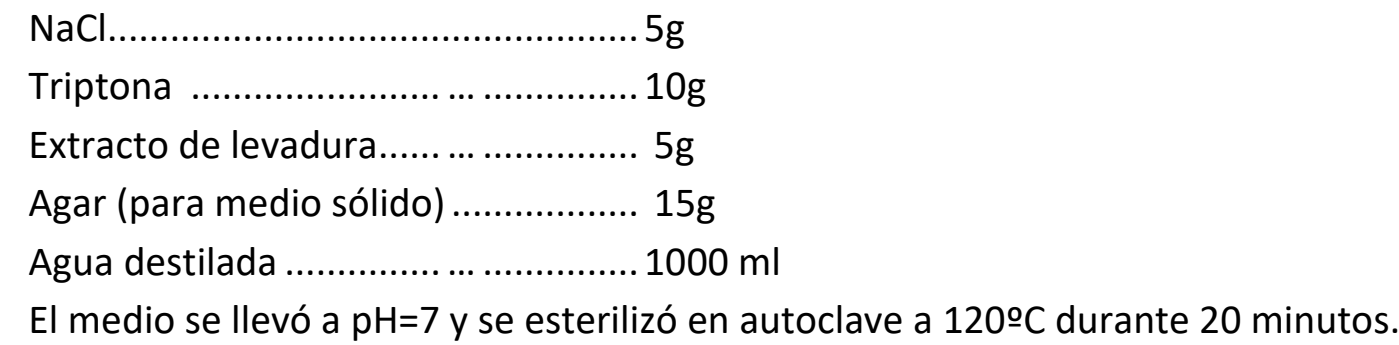


Las cepas de $B$. diazoefficiens se cultivaron siempre a $28^{\circ} \mathrm{C}$, tanto en medio sólido como líquido (180 rpm), utilizando distintos medios de cultivo:

Yeast Extract Manitol (YEM) para crecimiento en medio sólido. (Vincent, 1970)

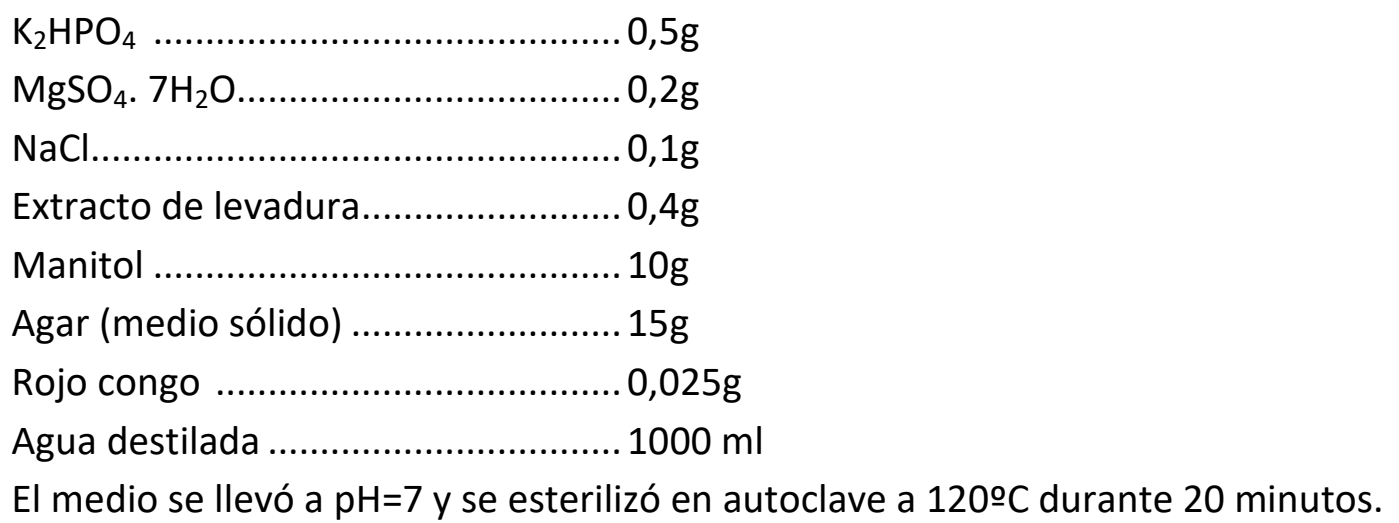

Peptone Salts Yeast extract modificado (PSY-ara) para crecimiento en medios líquidos. (Regensburger y Hennecke,1983)

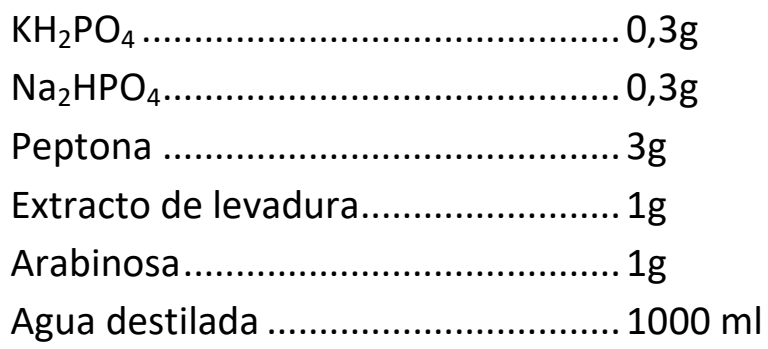

El medio se llevó a $\mathrm{pH}=7$ y se esterilizó en autoclave a 120 ㄷ C durante 20 minutos. Luego se completó con soluciones concentradas estériles de los siguientes compuestos.

\begin{tabular}{|c|c|}
\hline $\mathrm{MgSO}_{4 .} .7 \mathrm{H}_{2} \mathrm{O}(1000 \mathrm{X}) \ldots \ldots \ldots \ldots \ldots \ldots . . . . . . . . . . . .10 \mathrm{~g} / \mathrm{I}$ & \\
\hline $\mathrm{CaCl}_{2} .2 \mathrm{H}_{2} \mathrm{O}(1000 \mathrm{X}) \ldots \ldots \ldots \ldots \ldots \ldots \ldots \ldots \ldots \ldots \ldots \ldots \ldots \ldots . . . .5 \mathrm{~g} / \mathrm{l}$ & \\
\hline 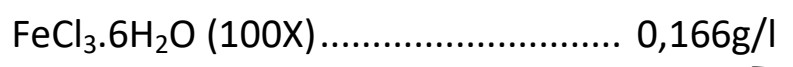 & \\
\hline 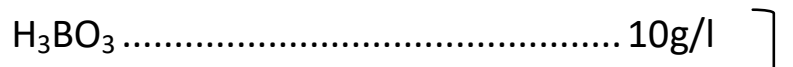 & \\
\hline 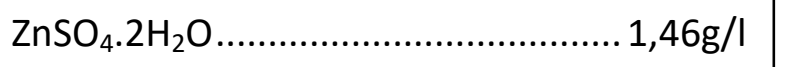 & \\
\hline 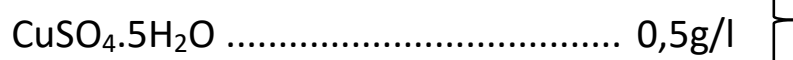 & Micronutrientes (1000X) \\
\hline 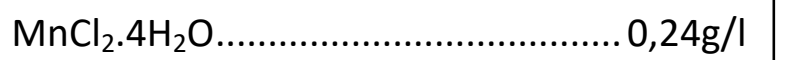 & \\
\hline 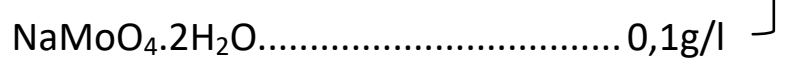 & \\
\hline 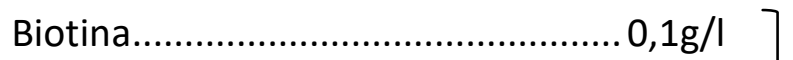 & \\
\hline Clorhidrato de tiamina .................... 0,1g/l & Vitaminas (1000x) \\
\hline Pantotenato sódico ......................... 0,1g/l & \\
\hline
\end{tabular}


Para ensayos de movilidad se utilizó el medio AG tanto para medios líquidos como para medios semisólidos. (Sadowsky et al.,1987)

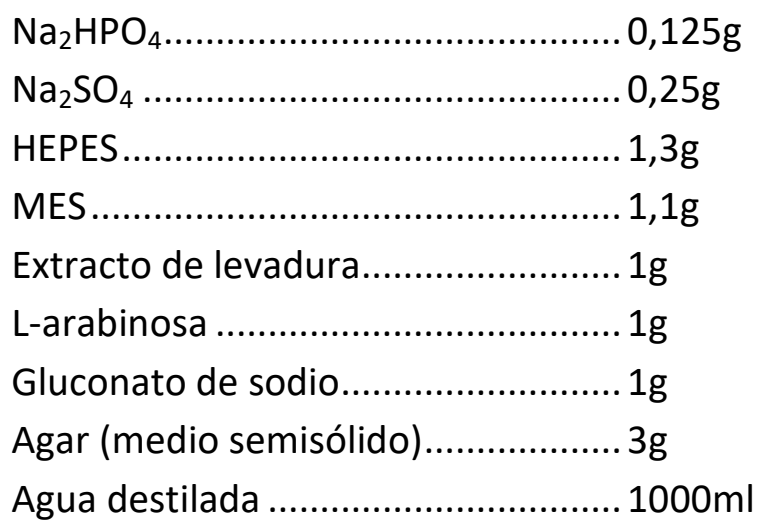

El medio se llevó a $\mathrm{pH}=7$ y se esterilizó en autoclave a $120^{\circ} \mathrm{C}$ durante 20 minutos. Luego se completó con soluciones concentradas estériles de los siguientes compuestos.

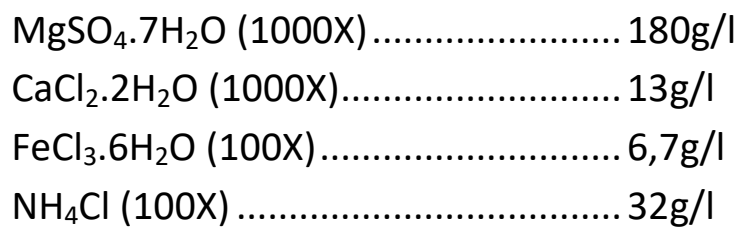

\section{II.3.2. Conservación de las bacterias}

Las bacterias fueron crecidas en placas YEM con Rojo Congo o LB y guardadas en solución de YEM/LB con glicerol $50 \% \mathrm{v} / \mathrm{v}$ a -20 ㄷ C. Para guardar a $-80^{\circ} \mathrm{C}$ se utilizó una solución YEM/LB glicerol 20\% v/v.

Siempre que fue necesario se plaquearon alícuotas de los stock de $-20 \circ \mathrm{C}$ en placas YEM con RC y luego de un período de crecimiento en estufa, fueron guardadas a 4으 cerradas con parafilm.

\section{II.3.3 Cultivos bacterianos y preparación de inóculos}

Para realizar la mayoría de los ensayos, los inóculos fueron preparados partiendo de colonias crecidas en placa y a partir de allí se realizó un primer cultivo líquido de $10 \mathrm{ml}$ (siempre en presencia de antibiótico) hasta alcanzar fase estacionaria. A partir de ese cultivo, se realizó una primera dilución sin antibiótico de manera de obtener un cultivo cuya $\mathrm{DO}_{500}$ inicial sea 0,1 e incubados hasta alcanzar fase exponencial de crecimiento $\left(\mathrm{DO}_{500}=1\right)$. Luego se realizó una segunda y última dilución a $\mathrm{DO}_{500}$ inicial 0,01 y cosechadas a la $\mathrm{DO}_{500}$ final deseada. 


\section{II.3.4 Estimación de la biomasa y recuento en placa}

La biomasa se estimó mediante lecturas de densidad óptica a $\mathrm{DO}_{500}$ y cuando fue necesario a $\mathrm{DO}_{600}$. El número de bacterias viables o unidades formadoras de colonias (UFC) fue realizado mediante el recuento en placa de tres diluciones seriadas de cultivo y cuantificación de 5-30 colonias de 10-15 gotas de $5 \mu$ l (Hoben et al., 1982).

\section{II.3.5 Antibióticos}

Los antibióticos utilizados fueron preparados en una concentración de 1000X en agua bidestilada, con excepción de cloranfenicol, tetraciclina y espectinomicina que fueron preparadas en metanol. La esterilización se realizó por filtración (filtros Millipore de 0,22 $\mu \mathrm{m}$ ). En la Tabla II.3 se detallan las concentraciones finales de cada uno de los antibióticos utilizados.

Tabla II.3 - Concentraciones de antibióticos utilizadas en este trabajo.

La tabla muestra las concentraciones finales de antibióticos en medios sólidos o líquidos utilizadas para E. coli o B. diazoefficiens.

\begin{tabular}{|c|c|c|c|c|}
\hline \multirow[b]{2}{*}{ Antibiótico } & \multicolumn{2}{|c|}{ E. coli } & \multicolumn{2}{|c|}{ B. diazoefficiens } \\
\hline & $\begin{array}{l}\text { Medio sólido } \\
\qquad(\mu \mathrm{g} / \mathrm{ml})\end{array}$ & $\begin{array}{l}\text { Medio líquido } \\
\qquad(\mu \mathrm{g} / \mathrm{ml})\end{array}$ & $\begin{array}{l}\text { Medio sólido } \\
\qquad(\mu \mathrm{g} / \mathrm{ml})\end{array}$ & $\begin{array}{c}\text { Medio líquido } \\
(\mu \mathrm{g} / \mathrm{ml})\end{array}$ \\
\hline Kanamicina sulfato & 25 & 25 & 150 & 150 \\
\hline Ampicilina & 200 & 200 & - & - \\
\hline Tetraciclina & 10 & 10 & 100 & 15 \\
\hline Gentamicina & 10 & 10 & 100 & 25 \\
\hline Cloranfenicol & & & 20 & - \\
\hline Espectinomicina & & & 200 & 200 \\
\hline
\end{tabular}

\section{II.3.6 Preparación de células electrocompetentes de E. coli}

La preparación de células electrocompetentes fue realizada según Tung y Chow (1995), con leves modificaciones. Se inocularon $300 \mathrm{ml}$ de medio LB $\sin \mathrm{NaCl}$, con $1 \mathrm{ml}$ de un cultivo de la cepa $E$. coli $\mathrm{DH} 5 \alpha$ o S17-1 crecido previamente. El cultivo fue incubado a $37^{\circ} \mathrm{C}$ y agitado a $180 \mathrm{rpm}$ en agitador orbital hasta que se alcanzó una $\mathrm{DO}_{600}$ de 0,6 unidades; momento en el cual se procedió al enfriamiento del cultivo en agua hielo durante 30 minutos. Luego, las células se centrifugaron 15 minutos a 4.000 $x$ g. y se lavaron con $50 \mathrm{ml}$ de glicerol $10 \%$ frío. Este procedimiento se realizó dos veces a $4^{\circ} \mathrm{C}$. Las bacterias se resuspendieron suavemente en glicerol $10 \%$ frío y se fraccionaron en alícuotas de $100 \mu \mathrm{l}$, que se conservaron $-80^{\circ} \mathrm{C}$. 


\section{II.3.7 Electrotransformación de células electrocompetentes de E. coli}

Las reacciones deligación fueron desaladas por osmosis utilizando membranas de ultrafiltración (Millipore) y luego transferidas a células electrocompetentes de $E$. coli DH5 $\alpha$ mediante la técnica de electrotransformación. Los plásmidos purificados por miniprep se transformaron directamente a células E. coli S17-1. En ambos casos se utilizó un equipo Gene Pulser (Bio-Rad) y cubetas comerciales de 0,2 cm de ancho (Gene Pulser Cuvette Bio-Rad), bajo las condiciones recomendadas por el fabricante $(25 \mu \mathrm{F}, 20 \Omega 0,2,5 \mathrm{kV})$. Inmediatamente después de la electrotransformación, se adicionó a las células $1 \mathrm{ml}$ de medio LB fresco, y la suspensión se incubó 1 hora a $37^{\circ} \mathrm{C}$ para activar el metabolismo de las bacterias. Pasado este tiempo, se plaquearon (alícuotas de diluciones $1 / 10$, del cultivo directo o el pellet centrifugado) en medio LB sólido con antibiótico y se incubaron el tiempo necesario en estufa a $37^{\circ} \mathrm{C}$.

\section{II.3.8 Conjugaciones biparentales}

Las conjugaciones fueron realizadas empleando la técnica de Simon (Simon et al., 1989) con modificaciones menores según se indica a continuación. Las cepas aceptoras de $B$. diazoefficiens fueron crecidas en el medio PSY-ara sin antibiótico durante 3 días hasta una $\mathrm{DO}_{500}$ aproximada de 1 unidad. Las cepas de $E$. coli S17-1 fueron crecidas en medio LB con antibiótico overnight y se diluyeron a medio LB fresco sin antibiótico hasta alcanzar una $\mathrm{DO}_{600}$ similar.

Para realizar la conjugación se mezclaron cantidades iguales de cada una de las cepas y se centrifugaron a $640 \mathrm{x}$ g durante 8 minutos. El precipitado fue resuspendido suavemente en 50-75 $\mu \mathrm{l}$ del mismo medio, colocado en placas de PSY-ara sólido en forma de gota e incubaba durante 48 horas a $28^{\circ} \mathrm{C}$. Luego la gota fue resuspendida en $1 \mathrm{ml}$ de medio YEM fresco y plaqueada en el/los antibiótico/s correspondiente/s para la selección de transconjugantes. El mismo procedimiento se realizó individualmente con cada una de las cepas como control negativo de la conjugación.

\section{II.3.9 Ensayos de natación en agar semisólido}

Los ensayos de natación en agar semisólido se realizaron en cajas de Petri de 90 $\mathrm{mm}$ de diámetro con $25 \mathrm{~mL}$ de medio AG y concentración de agar 0,3\% p/v, y luego se incubaron pinchando con un palillo en el centro de cada placa. Cuando las bacterias comenzaron a nadar, se registró el diámetro del halo de natación (mediante observación de la turbidez producida por las bacterias que se han desplazado desde el centro de la placa) en función de los días. 


\section{II.3.10 Observación y cuantificación de exopolisacáridos (EPS)}

\section{II.2.10.a Ensayo de unión a Rojo Congo (RC)}

El Rojo Congo (RC) es capaz de unirse a unidades D-glucopiranosil de polisacáridos neutros o básicos y a algunas proteínas y por esta razón es utilizado para estimar la cantidad de EPS producida (Spiers et al., 2003).

Las cepas se crecieron en PSY-ara hasta alcanzar fase exponencial $\left(\mathrm{DO}_{500}=1\right)$ y se plaquearon tres gotas de $5 \mu \mathrm{l}$ en placas PSY-ara. Transcurridos 3 días de crecimiento a 28 드, las gotas se resuspendieron en $1 \mathrm{ml}$. de una solución de $\mathrm{RC}(0,005 \% \mathrm{p} / \mathrm{v})$. Luego de 2 hs. de incubación a 37 ํㅡ se centrifugó a 16.000 x g y se tomó el sobrenadante. La absorbancia del mismo fue medida a 490nm. y relativizada en función de la absorbancia de la cepa control.

$$
A_{\text {relativa }}=\left(A_{R C \text { cepa }} / A_{R C \text { cepa control })}\right.
$$

\section{II.3.10.b Cuantificación de EPS mediante el método de Antrona}

Para la extracción de EPS, las bacterias se cultivaron en $25 \mathrm{ml}$. de medio PSY-ara hasta alcanzar una $\mathrm{DO}_{500}: 0,7$ (exponencial) o $\mathrm{DO}_{500}: 3$ (estacionaria) y se cosecharon $10 \mathrm{ml}$ por centrifugación a $12000 \times \mathrm{g}$ por $45 \mathrm{~min}$ a $4{ }^{\circ} \mathrm{C}$. El sobrenadante fue precipitado con 3 volúmenes de alcohol $96 \%$ e incubado a -20 ㅇ C durante toda la noche. El pellet se separó por centrifugación a 12000 x g por $45 \mathrm{~min}$ a 4 ํㅡ. El precipitado se resuspendió en $2 \mathrm{ml}$. de agua bidestilada.

Para la cuantificación se realizó una curva de calibración utilizando una solución de glucosa $1 \mathrm{mg} / \mathrm{ml}$ como patrón y una solución de Antrona en $\mathrm{H}_{2} \mathrm{SO}_{4}$ (0,2\% p/v). Luego las muestras fueron hervidas durante $10 \mathrm{~min}$. y la absorbancia fue medida a $620 \mathrm{~nm}$. Las medidas fueron realizadas por triplicado, tanto para la curva de calibración como para el resto de las muestras. Luego se realizó un promedio de las réplicas biológicas expresadas como $\mu \mathrm{g}$ EPS/ml y se analizaron las diferencias utilizando ANOVA.

\section{II.3.11 Ensayos de adhesión a tubos de vidrio}

Para el ensayo de adhesión a vidrio se partió de cultivos crecidos hasta fase exponencial, de los cuales se realizó una dilución para alcanzar una $\mathrm{DO}_{500}$ inicial de 0,08 . Para la determinación se inocularon $4 \mathrm{ml}$ de esta dilución en tubos de vidrio de $16 \mathrm{~cm}$ de alto y $150 \mathrm{~mm}$ de radio. Los mismos fueron crecidos a $28^{\circ} \mathrm{C}$ a $100 \mathrm{rpm}$, durante 3, 5 o 7 días. Luego el sobrenadante fue descartado y los tubos fueron lavados tres veces con agua destilada y secados a 65 으. Seguidamente se tiñeron los halos con una solución de Cristal Violeta $1 \% \mathrm{p} / \mathrm{v}$ durante $15 \mathrm{~min}$. Los tubos fueron lavados tres veces con agua destilada y secados nuevamente. El colorante adherido fue extraído 
utilizando una solución de ácido acético $33 \% \mathrm{p} / \mathrm{v}$ y su absorbancia fue medida a $595 \mathrm{~nm}$.

\section{II.3.12 Ensayos de sensibilidad a SDS}

Para el ensayo de resistencia a SDS se inoculó medio PSY-ara (0,9\% p/v de agar) fundido con los cultivos crecidos en este mismo medio alcanzando una $\mathrm{DO}_{500}=0.08$. Luego se posaron discos de papel de filtro estériles $(0,6 \mathrm{~cm})$ sobre las placas solidificadas y se le agregó una gota de $10 \mu \mathrm{l}$ de agua bidestilada o de una solución $5 \%$ $\mathrm{p} / \mathrm{v}$ de SDS. Luego de dos semanas de incubación a $28^{\circ} \mathrm{C}$ se registraron los halos de inhibición. Modificado de Calatrava-Morales y col. (2017).

\section{II.4 Técnicas de biología molecular}

\section{II.4.1 Preparación de ADN plasmídico}

Los plásmidos de $E$. coli fueron preparados por la técnica de lisis alcalina descripta por Sambrook (Sambrook, 1989). Brevemente, se suspendieron bacterias crecidas en medio sólido en una solución Tris- $\mathrm{HCl} 50 \mathrm{mM}$, EDTA $10 \mathrm{mM}, \mathrm{pH}=8.0$. Se agregó luego una solución de $\mathrm{NaOH} 0,4 \mathrm{~N}$, SDS $2 \%$ y se mezcló por inversión suave. Finalmente, se agregó una solución de KAc $3 \mathrm{M}, \mathrm{pH}=4.8$ mezclando suavemente. Luego se centrifugó la mezcla a $16.000 \times \mathrm{g}$ durante 15 minutos y al sobrenadante se le agregó una suspensión de óxido de silicio (Sigma 99\%). Se centrifugó a 16.000 x g y se lavó el sedimento tres veces con una solución de $\mathrm{NaCl} 50 \mathrm{mM}$, Tris $10 \mathrm{mM} \mathrm{pH=7.5,} \mathrm{EDTA} \mathrm{2,5}$ $\mathrm{mM}$ y etanol $50 \%$. Posteriormente se dejó secar y se resuspendió en 20-30 $\mu \mathrm{l}$ de agua bidestilada, se incubó durante 5 minutos a $65^{\circ} \mathrm{C}$, se centrifugó a 16.000 x g y se tomó el sobrenadante conteniendo el ADN plasmídico.

\section{II.4.2 Extracción de ADN total}

Se utilizaron dos técnicas de extracción de ADN total como molde para la reacción en cadena de la polimerasa (Capítulo II.4.5). Ambas fueron realizadas mediante lisis por calor.

Las células de los cultivos líquidos fueron lavadas primeramente con una solución $\mathrm{NaCl} 1 \mathrm{M}$ y luego con agua bidestilada. Seguidamente se agregó una suspensión de Resina (CHELEX) y se llevó a 56드 por 20 minutos. Luego de mezclar la suspensión se hirvió la misma por 8 minutos, se centrifugó a 16.000 x g y separó el sobrenadante. Para las reacciones de PCR se utilizó $1 \mu \mathrm{l}$ de esta preparación como molde.

Las bacterias crecidas en medio sólido fueron resupendidas en 50-100 $\mu$ de agua bidestilada estéril. La suspensión fue hervida durante 10 minutos y centrifugada a $16.000 \times$ g por 10 minutos; $2 \mu \mathrm{l}$ de los sobrenadantes fueron usados como ADN molde. 


\section{II.4.3 Extracción de ARN total}

La extracción de ARN total de $B$. diazoefficiens se realizó a partir de cultivos en fase exponencial $\mathrm{DO}_{600}=0,5$ en medio PSY-ara, los cuales fueron centrifugados a $12.000 \times \mathrm{g}$ durante 25 minutos a $4^{\circ} \mathrm{C}$. Posteriormente, los precipitados se resuspendieron en buffer TE $\mathrm{pH} 8$ y las bacterias fueron lisadas agregando lisozima y posterior incubación a $37^{\circ} \mathrm{C}$ por 30 minutos. La lisis finalmente se completó con la adición del Trizol (Invitrogen). Posteriormente se siguieron los pasos indicados por el fabricante. EI ARN se resupendió en agua bidestilada tratada con DEPC y se cuantificó por medida de su absorbancia a $260 \mathrm{~nm}$. Cada muestra se trató luego con ADNasa I (Invitrogen) según lo indica el fabricante para eliminar cualquier contaminación de ADN que existiese. Se verificó la ausencia de ADN realizando una PCR previa a la retrotranscripción. La muestra conteniendo ARN se conservó a $-80^{\circ} \mathrm{C}$.

\section{II.4.4 Transcripción reversa, RT-PCR y qRT-PCR}

El proceso de retrotanscripción (RT-PCR) fue realizado con la enzima MMLV (Invitrogen) utilizando hexámeros al azar (random primers) para obtener los ADN complementarios (ADNc) según las indicaciones del fabricante.

Para las RT-PCR se realizaron las reacciones de PCR para cada gen de interés en cada una de las cepas, en tubos separados utilizando como molde el ADNc.

Para las la RT-PCR en tiempo real (qRT-PCR) se realizó la cuantificación usando iQ SYBR Green Supermix (BioRad) siguiendo los datos del fabricante y se utilizó el equipo qTOWER 2.2. Los datos fueron normalizados utilizando el método $\Delta \Delta \mathrm{C}_{\mathrm{T}}$ (Pfaffl, 2001) utilizando el gen sigA como control gen endógeno y la cepa WT como control.

$$
\begin{aligned}
& \mathrm{Rq}=2^{-\Delta \Delta C_{T}} \\
& \text { Foldchange }=\frac{R q_{m u t}}{R q_{w t}}
\end{aligned}
$$

Los primers fueron diseñados con especial cuidado siguiendo el instructivo (iQ SYBR Green Supermix) y poniendo énfasis en la especificidad de ellos dado que existen genes parálogos para la mayoría de los genes flagelares. En la Tabla II.4 se muestran los primers utilizados en este trabajo. 
Tabla II.4 - Primers para RT-PCR y qRT-PCR.

\begin{tabular}{|c|c|c|c|}
\hline Nombre & Secuencia & Gen & Referencia \\
\hline \multicolumn{4}{|c|}{ Control endógeno } \\
\hline sigA_Fw & CTGATCCAGGAAGGCAACATC & \multirow{2}{*}{$\sigma^{70}$} & \multirow{2}{*}{ Hauser et al.,2007 } \\
\hline sigA_Rv & TGGCGTAGGTCGAGAACTTGT & & \\
\hline \multicolumn{4}{|c|}{ Genes reguladores } \\
\hline q5837_Fw & ATGCTGCGGCGAACCTGAA & \multirow{2}{*}{ flix } & \multirow{12}{*}{ Esta tesis } \\
\hline q5837_Rv & ATCTCGGACAGCACGGAATCG & & \\
\hline q7003_Fw & GTCAACCTGAAGATCCCACC & \multirow{2}{*}{$f l b D$} & \\
\hline q7003_Fw & TTGGCTTCGGCGTACTTCTT & & \\
\hline q5842_Fw & ATCGATGTCCGCCAGAAGAT & \multirow{2}{*}{$f l a F_{S}$} & \\
\hline q5842_Rv & GGCAGCGATATTGCGATTGA & & \\
\hline q5847_Fw & CACGGCACCTATTTCAACCTC & \multirow{2}{*}{$f l b T_{S}$} & \\
\hline q5847_Rv & CAGGATGTTGTTGTTGATGGCT & & \\
\hline q5808_Fw & ATCCAGTCGTGGGTCGTATC & \multirow{2}{*}{$c c k A$} & \\
\hline q5808_Rv & TCAGATAGGCCGCATTGGAA & & \\
\hline 2200_FwE & AAAAgaattcCGTCTTGGTGTCGAGGTTGA & \multirow{2}{*}{$\operatorname{ctr} A$} & \\
\hline 2200_RvH & AAAaagcttCGATTCTGATCCTCTCCGGC & & \\
\hline lafR_Fw & CGAAACAGGGGCGAAAGAC & \multirow{2}{*}{ lafR } & \multirow{2}{*}{$\begin{array}{l}\text { Mongiardini et al., } \\
2016\end{array}$} \\
\hline q6846int_Rv & GGTCCGATTCACTCGCAGA & & \\
\hline \multicolumn{4}{|c|}{ Sistema de Secreción Tipo III } \\
\hline q2201_Fw & CAAGTGATGGCGACCTATGC & \multirow{2}{*}{ flil } & \multirow{6}{*}{ Esta tesis } \\
\hline q2201_Rv & GGTAACCGTCCGCCAATGA & & \\
\hline q2207_Fw & GCCCTGATGAAGCAGTTCTC & \multirow{2}{*}{ flhA } & \\
\hline q2207_Rv & GGAAGGGAATGGTCGGAATG & & \\
\hline q5816_Fw & CCTCCCGCGTAGAGTTCTTT & \multirow{2}{*}{ flip } & \\
\hline q5816_Rv & ATTGATGCTGATGTCCTGCG & & \\
\hline \multicolumn{4}{|c|}{ Anillos y motor } \\
\hline q5826_Fw & GTCACCGACATCTTCCAGAC & \multirow{2}{*}{ flit } & \multirow{8}{*}{ Esta tesis } \\
\hline q5826_Rv & CTTGGTCAGCTCTTCCTTGAG & & \\
\hline q5838_Fw & GAGGATGGTCCGAGATTTGA & & \\
\hline q5838_Rv & CCAACAATCCTCACCCAACG & $f \lg l$ & \\
\hline q6999_Fw & GAGCAAGAAGACCGAGGAGACCAA & $f l i$ & \\
\hline q6999_Rv & CTCCTTGGTGCGGTCCTGATA & JIII & \\
\hline q3800_Fw & GATGAAGAGACCAACCGCAC & nom 1 & \\
\hline q3800_Rv & GATAGGCCAGCAGCATTTCG & pomA & \\
\hline Bastón & & & \\
\hline q5827_Fw & CTTCTGATCGGCTTGTCACG & & \\
\hline q5827_Rv & AGAAACTCCTCGAACAGCGA & Jlgr & \\
\hline q5814_Fw & TTCGACCAGAACAGGAATGC & & Esta tesis \\
\hline q5814_Rv & GCGTAATCCATCTGGTTGCT & $f \lg B$ & \\
\hline Gancho & & & \\
\hline q3696_Fw & ATATCACGGTGACCAGCACG & flin & \\
\hline q3696_Rv & CCCGTCAGCACCATCTCATA & fIID & \\
\hline q3699_Fw & TTCGGTTACTCGCTGTCCTC & & \\
\hline q3699_Rv & GGTTGCCGCTGGAGTCCTT & $f \lg D_{3}$ & \\
\hline q5854_Fw & ATCAGCGGCGGTGCGGTCA & & Esta tesıs \\
\hline q5854_Rv & AGAACAGGTTCCAGGTATCGG & $f \lg E_{5}$ & \\
\hline q6996_Fw & ACGTCAGATGTAGCTGCCA & & \\
\hline q6996_Rv & TCGCCTGGGTATTACTGTCG & flik & \\
\hline Filamento & & & \\
\hline q5843_Fw & GTTCAAGAGGAAGACTCGCC & & \\
\hline q5843_Rv & GTTGACCTTCTTGCCGGTTG & & Esta tesis \\
\hline q5844_Fw & GAAGACGCGTAAGCCAGAAG & flic2 & \\
\hline
\end{tabular}




$\begin{array}{lll}\text { q5844_Rv } & \text { GACGGTTCTGTGTGGTGG } & \text { fliC3 } \\ \text { q5845_Fw } & \text { TTAATCCTAATCGAAGTTTGTTGCG } \\ \text { q5845_Rv } & \text { CGGTGGACTGGAGAGAAAGA } & \text { fliC4 } \\ \text { q5846_Fw } & \text { GGTCAATCTCGATCCAAGCAGA } & \\ \text { q5846_Rv } & \text { ACGATGCCTGACATGACTCT } & \\ \text { Los números indicados en los nombres de los primers representan el locus tag del gen en } \\ \text { el que hibridan. }\end{array}$

\section{II.4.5 Reacción en Cadena de la Polimerasa (PCR)}

Los ensayos de PCR fueron realizados empleando un ciclador térmico. La composición de las mezclas de reacción fue: buffer Tris- $\mathrm{HCl} 50 \mathrm{mM} \mathrm{pH}=8.3,3 \mathrm{mM}$ $\mathrm{MgCl}$; $200 \mu \mathrm{M}$ dNTPs; $1 \mathrm{U}$ de Taq polimerasa y $10 \mu \mathrm{M}$ de cada uno de los primers, completando un volumen final de mezcla de reacción, para todos los casos, de $10 \mu$ l.

Los primers empleados están listados en la Tabla II.5 y fueron sintetizados en su mayoría en Eurofins MWG. El ciclado se realizó respetando el esquema básico de una desnaturalización inicial de 3 minutos; 35 ciclos de desnaturalización, hibridación (annealing) y elongación; y por último, una elongación final. En todos los casos, la desnaturalización se realizó a $94^{\circ} \mathrm{C}$ y la elongación a $72^{\circ} \mathrm{C}$ (temperatura óptima de elongación de la Taq polimerasa). Dependiendo del juego de primers utilizado, se fijó la temperatura de annealing y los tiempos fueron determinados en función del largo del fragmento que se quiso amplificar en cada caso. Las reacciones de PCR fueron sembradas y separadas por tamaño mediante electroforesis en gel de agarosa.

En los casos donde se necesitó amplificar dejando extremos romos se utilizó la enzima de alta fidelidad Pfu (PBL) que posee actividad exonucleasa $3^{\prime}-5$ '. El ciclado se hizo respetando el siguiente esquema. Una desnaturalización inicial de 2 minutos; 35 ciclos de desnaturalización, hibridación (annealing) y elongación; y por último, una elongación final. La desnaturalización inicial se realizó a $94^{\circ} \mathrm{C}$ y luego a $92^{\circ} \mathrm{C}$ y la elongación a $68^{\circ} \mathrm{C}$. Dependiendo del juego de primers utilizado, se fijó la temperatura de annealing y los tiempos fueron determinados en función del largo del fragmento que se quiso amplificar en cada caso. 
Tabla II.5 - Primers para mutagénesis utilizados en este trabajo. En minúscula se encuentran marcados los sitios de restricción agregados en cada primer y subrayadas las secuencias complementarias agregadas para la estrategia de mutagénesis de bll5842 y el cambio puntual en el primer 7003 DxA.

\begin{tabular}{|c|c|c|c|}
\hline Nombre & Secuencia & Función & Referencia \\
\hline \multicolumn{4}{|c|}{ Primers universales } \\
\hline M13_Fw & GCGGATAACAATTTCACACAGG & $\begin{array}{l}\text { Chequeo de clonados en } \\
\text { pK18mobsacB - pG18mob2 - } \\
\text { pBBR1MCS3 }\end{array}$ & $\begin{array}{l}\text { Producto } \\
\text { comercial }\end{array}$ \\
\hline $\begin{array}{l}\text { pFAJ_Fw } \\
\text { pFAJ_Rv }\end{array}$ & $\begin{array}{l}\text { ACTGGGCTATCTGGACAAGG } \\
\text { TCGTTGTTGAGGACAACTGC }\end{array}$ & $\begin{array}{l}\text { Chequeo de clonados en } \\
\text { pFAJ1708 }\end{array}$ & $\begin{array}{l}\text { Quelas, sin } \\
\text { publicar }\end{array}$ \\
\hline $\begin{array}{l}\mathrm{Km} \_\mathrm{Fw} \\
\mathrm{Km} \_\mathrm{Rv}\end{array}$ & $\begin{array}{l}\text { CATCGGGCTTCCCATACA } \\
\text { TGCCATTCTCACCGGATT }\end{array}$ & $\begin{array}{l}\text { Chequeo de presencia del } \\
\text { cassette } \mathrm{Km}\end{array}$ & $\begin{array}{l}\text { Quelas et al., } \\
\text { 2016b }\end{array}$ \\
\hline \multicolumn{4}{|c|}{ Primers específicos } \\
\hline $\begin{array}{l}\text { 1510_Fw } \\
1510 \_R v \\
\text { Ext1510_Fw } \\
\text { Ext1510_Rv }\end{array}$ & $\begin{array}{l}\text { AAGTTGATCTGCGGGTAGGC } \\
\text { CACCGTGCGCGAATATGG } \\
\text { TCGGCACCAGATCCTTGC } \\
\text { CGACACGCTGAAGGAGGG }\end{array}$ & $\begin{array}{l}\text { Clonado de bll1510 } \\
\text { Chequeo del evento de doble } \\
\text { recombinación bll1510 }\end{array}$ & \\
\hline $\begin{array}{l}\text { 3699_FwX } \\
\text { 3699_RvH }\end{array}$ & $\begin{array}{l}\text { AAtctagaCTAGAACCGGGGTGTGCG } \\
\text { AAAAAgcttgaAAGTGCGCCGGTGAG }\end{array}$ & Clonado de blr3699 & \\
\hline Ext3699_Fw & CCACAGTTCTTCATCTCTGCC & \multirow{3}{*}{$\begin{array}{l}\text { Chequeo del evento de doble } \\
\text { recombinación blr3699 } \\
\text { Clonado del fragmento Up de } \\
\text { bll2200 }\end{array}$} & \\
\hline Ext3699_Rv & GACCCTGCTGGGTGAGGT & & Esta tesis \\
\hline $\begin{array}{l}\text { Up2200_Fw2 } \\
\text { E } \\
\text { Up2200_RvH }\end{array}$ & AAAAgaattcATCATCGTTCCCCCATCGTG & & \\
\hline Dw2200_FwP & AActgcagTCTTGGTGTCGAGGTTGACG & \multirow{2}{*}{$\begin{array}{l}\text { Clonado del fragmento Dw de } \\
\text { bll2200 }\end{array}$} & \\
\hline Dw2200_Rv & ACGGAGCCGGATAACGAAAG & & \\
\hline $\begin{array}{l}\text { 5808_FwH } \\
5808 \_R v B\end{array}$ & $\begin{array}{l}\text { AAAAAgcttagCTTGACCTTCTCGCCG } \\
\text { AAAggatccCTTCGACCACACGCCGAT }\end{array}$ & Clonado de bll5808 & \\
\hline $\begin{array}{l}\text { 7003_FwE } \\
\text { 7003_RvH }\end{array}$ & $\begin{array}{l}\text { AAAAgaattcTCAAGACCGAACGCACGTAA } \\
\text { AAAAagcttcGGCGTATTCGTTGAGCTTG }\end{array}$ & Clonado de blr7003 & \\
\hline Ext7003_FwP & AActgcagGGCCATCGACATCTACGTCA & $\begin{array}{l}\text { Chequeo del evento de doble } \\
\text { recombinación blr7003 y } \\
\text { clonado para complemetación }\end{array}$ & \\
\hline 7003DxA_Fw & СCTCCTGCTGGTCGㄷGT & \multirow{2}{*}{$\begin{array}{l}\text { Clonado blr7003 con cambio } \\
\text { puntual }\end{array}$} & \\
\hline 7003DxA_Rv & ACG $\underline{G} C G A C C A G C A G G A G G$ & & \\
\hline $\begin{array}{l}\text { 5837_Fw } \\
5837 \_R v\end{array}$ & $\begin{array}{l}\text { TATCACGCAACTCGGGCTTAC } \\
\text { CCCAACAATCCTCACCCAAC }\end{array}$ & Clonado de bll5837 & Esta tesis \\
\hline Ext5837_Fw & ACAAATGGGCGGTGCTGA & \multirow{2}{*}{$\begin{array}{l}\text { Chequeo del evento de doble } \\
\text { recombinación bll5837 }\end{array}$} & \\
\hline Ext5837_Rv & CCGCACGCCCTCGATATT & & \\
\hline Up5842_FwE & AAAAgaattcTATCGAGCGTGGCAACCG & \multirow{2}{*}{$\begin{array}{l}\text { Clonado del fragmento Up de } \\
\text { bll5842 }\end{array}$} & \\
\hline Up5842_Rv & $\begin{array}{l}\text { GCCGTCGACggatccGAGGCAAGCCCGC } \\
\text { AGTTCGATCAC }\end{array}$ & & \\
\hline Dw5842_Fw & $\frac{\text { TGCCTCggatccGTCGACGGCACATCAAT }}{\text { CACACCCTGGAG }}$ & \multirow{2}{*}{$\begin{array}{l}\text { Clonado del fragmento Dw de } \\
\text { bll5842 }\end{array}$} & \\
\hline Dw5842_RvH & AAAAAgcttcgCTCCGCCGTTCTTTTTAC & & \\
\hline
\end{tabular}




$\begin{array}{llll}\text { Ext5842_Fw } & \text { GTGGTCAATCAGTTCCCCGA } & \begin{array}{l}\text { Chequeo del evento de doble } \\ \text { recombinación bll5842 }\end{array} \\ \text { Ext5842_Rv } & \text { GCTCATCGAACCTGACGCT } & & \text { Cedidos por el } \\ \text { PA1120_FwS } & \text { AAgagctcACAAGGCTGAACAGGGCG } & \text { Clonado de tpbB } & \text { Dr. Federico } \\ \text { PA1120_RvB } & \text { AAggatccCGTGCACCCGAGCGTATT } & & \text { Sisti }\end{array}$

\section{II.4.6 Tratamientos enzimáticos del ADN}

Las digestiones con enzimas de restricción se realizaron siguiendo las indicaciones de temperatura y buffer propuestas por el proveedor de las enzimas y las recomendaciones descriptas en Sambrook et al. (1989). Las reacciones se llevaron a cabo habitualmente con 0,5-5 $\mathrm{\mu g}$ de ADN en agua libre de ADNasas, el buffer correspondiente suministrado en el kit comercial $(10 \mathrm{X})$ y 0,5-1 unidad de la enzima a utilizar en un volumen final de $20 \mu \mathrm{l}$. Las mezclas de reacción fueron incubadas a la temperatura óptima de cada enzima usualmente overnight.

\section{II.4.7 Electroforesis en geles de agarosa}

La electroforesis horizontal en geles de agarosa se utilizó para observar las diferentes clases de ácidos nucleicos, la correcta digestión de los mismos y los tamaños de los amplicones obtenidos por PCR. El porcentaje de agarosa de la solución varió de 0,8-1,5\% p/v, preparada en buffer Tris-bórico-EDTA (TBE, Tris $89 \mathrm{mM}$, EDTA-Na 2 2,5 $\mathrm{mM}, \mathrm{BO}_{3} \mathrm{H}_{3} 89 \mathrm{mM}, \mathrm{pH}$ 8,2), de acuerdo al tamaño del producto de ADN que esperábamos observar. Las muestras se mezclaron para su siembra con solución de carga (sacarosa $40 \%$, azul de bromofenol $0,25 \%$ en una relación $5 \mu$ solución de ADN en agua o TE/ $\mu$ l solución de carga) y las corridas se realizaron a voltaje constante ( $80 \mathrm{a}$ 120 volts), utilizando como buffer de corrida el mismo TBE.

\section{II.4.8 Revelado de geles y fotografía}

La visualización de los fragmentos de ADN se realizó con el agregado de 0,5 $\mu \mathrm{g} \mathrm{ml-}$ 1 de bromuro de etidio a los geles de agarosa por transiluminación con luz ultravioleta de $\lambda=260 \mathrm{~nm}$. Como marcador de peso molecular se utilizó ADN del fago $\lambda$ digerido con HindIII o marcadores de peso molecular de $100 \mathrm{pb}$ o $1000 \mathrm{pb}$. El registro de los resultados se realizó mediante fotografía de los geles con una cámara digital Kodak modelo DC 120 (software-EDAS-Kodak) bajo iluminación ultravioleta. 


\section{II.4.9 Estrategias de clonado y mutagénesis}

Los clonados de los fragmentos correspondientes a las regiones $5^{\prime}$ y $3^{\prime}$ de los genes que fueron elegidos para estudiar mediante estrategias de mutagénesis se realizaron utilizando alguna de las siguientes estrategias.

1) PCR de la región 5' y $3^{\prime}$ y clonado de manera independiente cada uno de ellos en el vector deseado.

2) Clonado de un fragmento completo en un vector y posterior deleción de un fragmento interno del inserto clonado, por digestión con enzimas de restricción. El vector final se obtiene por religación de esta digestión.

3) PCR de la región 5' y 3', seguida de una tercera PCR para generar un único fragmento (Sukdeo y Charles, 2003), que luego será clonado en un vector. Esta estrategia requiere del diseño de dos primers externos que hibridan en la región que se quiere amplificar, y dos primers internos que contienen además de la región homóloga a la zona que se quiere amplificar, una secuencia adicional complementaria entre ambos (Figura II.1).

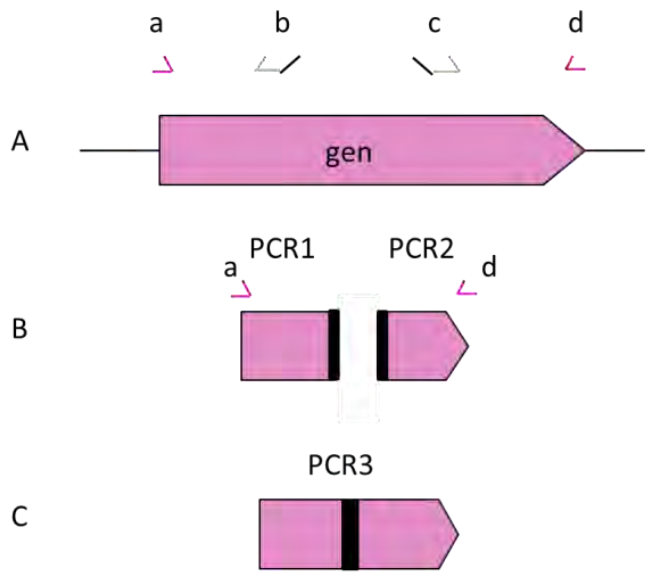

Figura II.1 Estrategia de clonado descripta por Sukdeo y Charles (2003). A. En un primer momento se realiza la PCR1 (utilizando los primers a y b) y la PCR2 (utilizando los primers $\mathrm{c}$ y d) sobre un molde de ADN. Las rayas negras representan la región complementaria de los primers b y $\mathrm{c}$. $\mathbf{B}$. Luego se realiza una tercera reacción de PCR (PCR3) utilizando los primers a y d y las PCR1 y PCR2 como molde. C. Los fragmentos quedan unidos y se amplifican durante la PCR3 dada la complementariedad entre las secuencias adicionales de los primers b y c.

Para la selección de mutantes, se utilizaron dos estrategias de mutagénesis diferentes. Una de ellas consiste en la inserción del cassette de antibiótico que otorga resistencia a $\mathrm{Km}$ o Gm, y la estrategia de mutagénesis "limpia" donde se deleciona el gen completo o un fragmento del mismo sin dejar una resistencia a un antibiótico.

\section{II.4.9.a Estrategia por inserción del cassette de antibiótico}

Para esta estrategia se construyó un vector conteniendo ambos extremos del gen diana interrumpido con el cassette de antibiótico. Para esto se utilizó el plásmido no replicativo en $B$. diazoefficiens USDA 110, pG18mob2 el cual lleva el gen que codifica la 
resistencia a Gentamicina $(\mathrm{Gm})$. El cassette que otorga resistencia a Kanamicina fue clonado a partir del plásmido pUC4K y fue utilizado para interrumpir el gen diana (Figura II.2).

En todos los casos la construcción fue transformada a la cepa de E. coli S17-1 y luego transferida a $B$. diazoefficiens por conjugación biparental. Los recombinantes dobles fueron seleccionados mediante resistencia a $\mathrm{Km}$ y sensibilidad a $\mathrm{Gm}$ mediante crecimiento de los transconjugantes en placas replicas en medio YEM. El evento de recombinación en los probables mutantes fue chequeado por PCR utilizando un primer externo a la zona de recombinación y un primer que hibrida en el cassette $\mathrm{Km}$. Estos productos de PCR se verificaron mediante secuenciación.

A

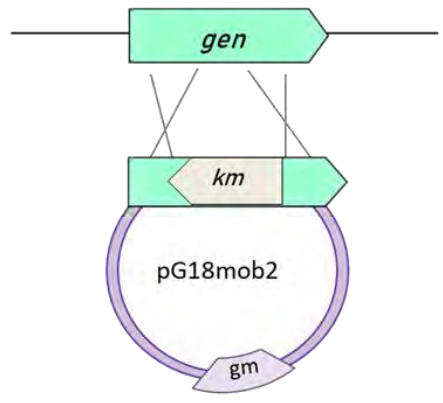

B

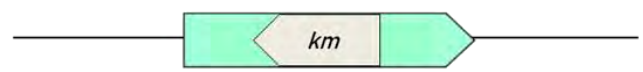

Figura II.2 - Estrategia de mutagénesis por inserción de Km. A. La imagen representa el evento de doble recombinación entre el gen presente en el genoma (arriba) y el gen clonado en el plásmido que contiene la inserción del cassette $\mathrm{Km}$. B. Mapa esquemático de la cepa mutante luego del proceso de doble recombinación homóloga $\left(\mathrm{Gm}^{S} \mathrm{Km}^{R}\right)$. Los clones $\mathrm{Gm}^{R}$ y $\mathrm{Km}^{\mathrm{R}}$ serán aquellos donde sólo ocurrió una simple recombinación.

\section{II.4.10.b Estrategia de deleción "limpia”}

Para esta estrategia se construyó un vector utilizando el plásmido pK18mobsacB conteniendo ambos extremos de la región que desea ser delecionada. Este plásmido es suicida en rizobios, y contiene un gen de resistencia a $\mathrm{Km}$ y el gen $s a c B$ el cual resulta tóxico en presencia de sacarosa (Figura II.3).

En todos los casos la construcción fue transformada a la cepa de E. coli S17-1 y luego transferida a $B$. diazoefficiens por conjugación biparental. En una primera instancia se seleccionaron recombinantes simples por resistencia al antibiótico $\mathrm{Km}$ presente en el plásmido (Figura II.3-B). La zona de recombinación fue chequeada por PCR utilizando primers que hibridan en el vector y en una región externa a la zona de recombinación. En una segunda instancia se seleccionaron recombinantes dobles mediante resistencia a $\mathrm{Km}$ y sensibilidad a sacarosa. Este segundo evento de recombinación puede resolver la pérdida del plásmido insertado en el cromosoma, 
generando el gen wildtype o produciendo la deleción del mismo (Figura II.3-C). La concentración de sacarosa utilizada fue $10 \% \mathrm{p} / \mathrm{v}$. Los clones fueron chequeados por PCR con primers que hibridan por fuera de la zona de recombinación y el amplicón fue enviado a secuenciar.

A

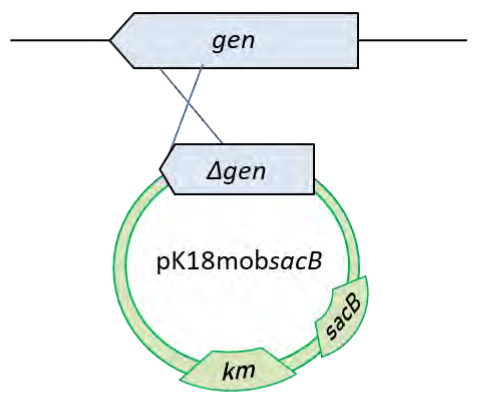

B

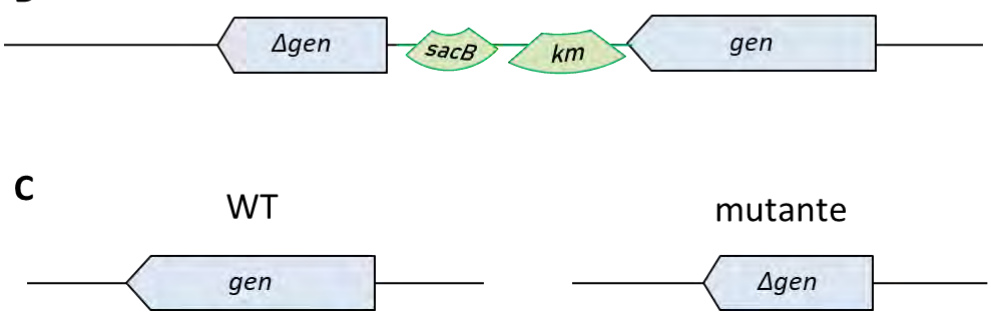

Figura II.3 - Estrategia de mutagénesis "limpia" A. La imagen representa uno de los dos posibles eventos de simple recombinación entre el gen presente en el genoma (arriba) y el fragmento del gen clonado en el plásmido que contiene la deleción. B. Mapa esquemático del cromosoma en la región donde se produjo la recombinación simple de la cepa $\mathrm{Km}^{R}$ y sensible a sacarosa. C. Mapa esquemático de los dos posibles transconjugantes luego de la resolución del plásmido (genotipo WT o genotipo mutante). Ambos serán $\mathrm{Km}^{\mathrm{s}}$ y resistentes a sacarosa. Cada genotipo se verifica por PCR.

\section{II.4.10 Secuenciación de ADN plasmídico y/o fragmentos de ADN}

EI ADN fue secuenciado utilizando un analizador $A B \mid 3730 X L$, por encargo en Macrogen Inc. (Corea del Sur) y analizado mediante el programa NTIVector 10.0.

\section{II.5 Manipulación de proteínas}

\section{II.5.1 Obtención de flagelinas extracelulares}

Los cultivos fueron realizados en medio AG $(30 \mathrm{ml}$ ) con antibiótico para las cepas que posean alguna resistencia específica, crecidos a $180 \mathrm{rpm}$ y $28^{\circ} \mathrm{C}$ hasta alcanzar saturación. Sólo en algunos casos específicos se cosecharon a una determinada DO. En el momento de ser procesados se pre-enfriaron en agua-hielo por 30 minutos, se 
agitaron con vortex cada uno durante 4 minutos y se centrifugaron a $12.000 \times \mathrm{g}$ durante 30 minutos a 4 으. El sobrenadante se precipitó con PEG 1,33\% y NaCl $166 \mathrm{mM}$ finales overnight a $4^{\circ} \mathrm{C}$. Posteriormente se centrifugaron a $12.000 \times \mathrm{g}$ durante 60 minutos y el precipitado se resuspendió en el menor volumen posible de buffer de siembra de geles desnaturalizantes (Laemmli, 1970).

\section{II.5.2 Análisis de proteínas mediante geles de poliacrilamida discontinuos en condiciones desnaturalizantes (SDS-PAGE)}

Se empleó la metodología de Laemmli (1970). Los geles de apilamiento se prepararon con $5 \%$ de poliacrilamida en Tris $-\mathrm{HCl}$ a $\mathrm{pH} 6,8$, mientras que los de separación se hicieron con $12,5 \%$ de poliacrilamida en Tris- $\mathrm{HCl}$ a $\mathrm{pH} 8,8$. En ambos casos con el agregado de dodecil sulfato de sodio (SDS) para obtener condiciones desnaturalizantes y disociantes. Las corridas se llevaron a cabo durante 30 a 60 minutos a voltaje constate de 90 o $110 \mathrm{v}$.

\section{II.5.3 Tinción de las proteínas}

Tinción Coomassie Blue R-250: para esta tinción el gel se incubó en solución de tinción (0.2\% Coomassie Blue R-250 disuelto en agua bidestilada, metanol, ácido acético (45:45:10) por al menos 1 hora. Para la visualización de las bandas el gel se destiñó en una solución agua: metanol: ácido acético en proporción 40:50:10.

\section{II.5.4 Identificación de los polipéptidos de flagelinas mediante espectrometría de masas}

Las muestras de flagelinas fueron obtenidas como mencionamos anteriormente, pero esta vez el volumen de cultivo utilizado fue de $50 \mathrm{ml}$ en medio PSY-ara y la condición de extracción fue realizada a $\mathrm{DO}_{600}=0,5$ (igual condición que la extracción de ARN). Las flagelinas fueron resuspendidas en agua y cuantificadas mediante el método de Bradford. Luego se sembraron cantidades iguales $(1 \mu \mathrm{g})$ de ambas muestras en un gel de poliacrilamida y se extrajo del gel la banda de flagelinas subpolares (65 kDa). Esa muestra fue enviada al CEQUIBIEM donde se extrajeron las proteínas del gel, se realizó la digestión tríptica y a través del procesamiento en el equipo HESI-Orbitrap modelo $Q$ Exactive acoplado a un nanoHPLC EASY-nLC 1000 (Thermo Scientific) se realizó un análisis peptídico comparativo de las flagelinas presentes. 


\section{II.6 Microscopía óptica}

Las muestras fueron crecidas en medio $A G$ y fueron observadas en fase exponencial o fase estacionaria. Las observaciones de las bacterias se llevaron a cabo con un microscopio óptico Nikon Eclipse E400 con aumento de $1000 \mathrm{X}$ y se registraron con una cámara digital Nikon CoolPix 4500.

\section{II.7 Ensayos de simbiosis}

\section{II.7.1 Plantas}

Se trabajó con Glycine max (soja), variedad Don Mario 4800, provista por el Ing. Agr. Alejandro Perticari del Instituto de Microbiología y Zoología Agrícola del Centro de Investigaciones en Ciencias Agropecuarias de INTA (Castelar, Pcia. de Buenos Aires).

\section{II.7.2 Medio de cultivo de plantas}

Las macetas fueron regadas con solución de Fåhraeus modificada (Lodeiro et al., 2000)

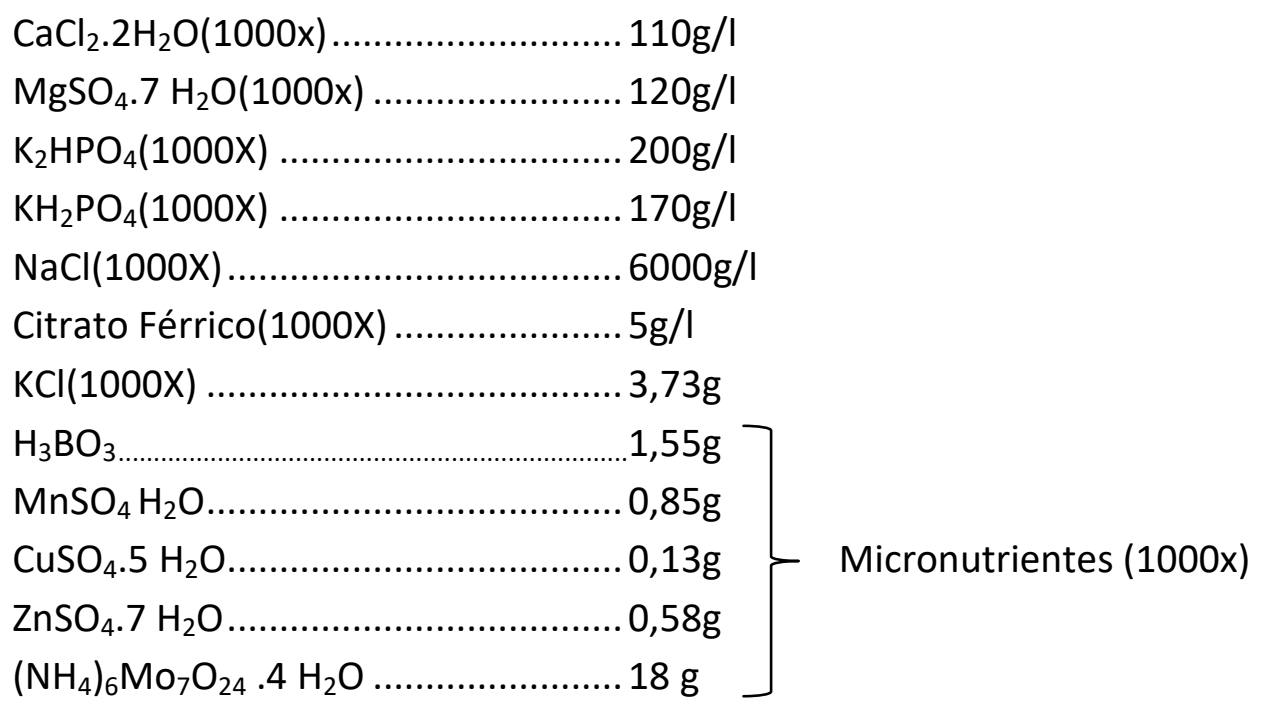

Se prepararon botellas de agua destilada con volumen determinado y fueron autoclavadas a 120 ㄷ por 20 minutos. En los casos que el volumen de agua fuese grande se autoclavaron dos veces. Luego se completaron con las soluciones estériles mencionadas arribas todas $1000 \mathrm{X}$. 


\section{II.7.3 Esterilización superficial y germinación de las semillas}

Las semillas se sumergieron unos segundos en alcohol 96 y luego diez minutos en solución de lavandina comercial diluida al $20 \%$ v/v con agitación a $28^{\circ} \mathrm{C}$. Seguidamente, se lavaron al menos seis veces con agua destilada estéril. Las semillas esterilizadas de esta manera se germinaron sobre una superficie de agar-agua al 1,5\% durante dos a cuatro días en la oscuridad a $28^{\circ} \mathrm{C}$.

\section{II.7.4 Ensayo de nodulación}

Las semillas germinadas fueron transferidas a macetas de $750 \mathrm{ml}$ utilizando perlita como soporte previamente regado con solución de Fåhraeus. Cada una de estas macetas fue inoculada con $1.10^{6}$ UFC proveniente de un cultivo en medio PSY-ara a $\mathrm{DO}_{600}=0,5$. Se utilizaron un total de 7-10 plantas por cada cepa a ensayar y fueron crecidas fijando la temperatura en $30^{\circ} \mathrm{C}$, período de luz y por un total de 21 días. Luego de ese período se extrajeron los nódulos para su recuento y posterior estimación de peso seco 
Capítulo III: Caracterización genómica del sistema flagelar subpolar de B. diazoefficiens USDA 110 



\section{III.1 Introducción}

En el año 2007, Kanbe y colaboradores identificaron, por comparación mediante búsqueda por similitud de secuencia a partir de genes descriptos en $E$. coli y Salmonella, algunos de los genes relacionados con los dos sistemas de flagelos en el genoma de B. diazoefficiens USDA 110 (Kanbe et al., 2007). Así, este grupo de investigación realizó la primera anotación funcional de genes flagelares de esta especie bacteriana, describiendo la presencia de dos grandes clusters de genes -además de otros posibles 5 o 6 clusters pequeños- que en general parecen tener funciones relacionadas con la síntesis de los flagelos (Figura III.1). Uno de estos clusters se encuentra ubicado en la región correspondiente a 7,5 Mpb (entre las bases 7.542.878 y 7.577.700) y es el único donde se encuentran codificados todos los componentes necesarios para la síntesis y regulación de los flagelos laterales (Kanbe et al., 2007; Mongiardini et al., 2017). La presencia de esta isla completa, que contiene los 41 genes del sistema flagelar lateral, hace suponer que la misma pudo ser adquirida por transferencia horizontal (Liu y Ochmann, 2007). Sin embargo, aún no se han podido determinar los sitios específicos de inserción que manifiesten dicho evento (GarridoSanz et al., 2019).

Así, los restantes 6 clusters presentes en el genoma de B. diazoefficiens USDA 110 contendrían los genes estructurales y regulatorios que podrían estar relacionados con la síntesis del sistema del flagelo subpolar. El cluster de mayor tamaño (mayor número de genes), que contiene los genes que codifican las flagelinas de esos flagelos, fue parcialmente caracterizado por Kanbe y col. (2007).

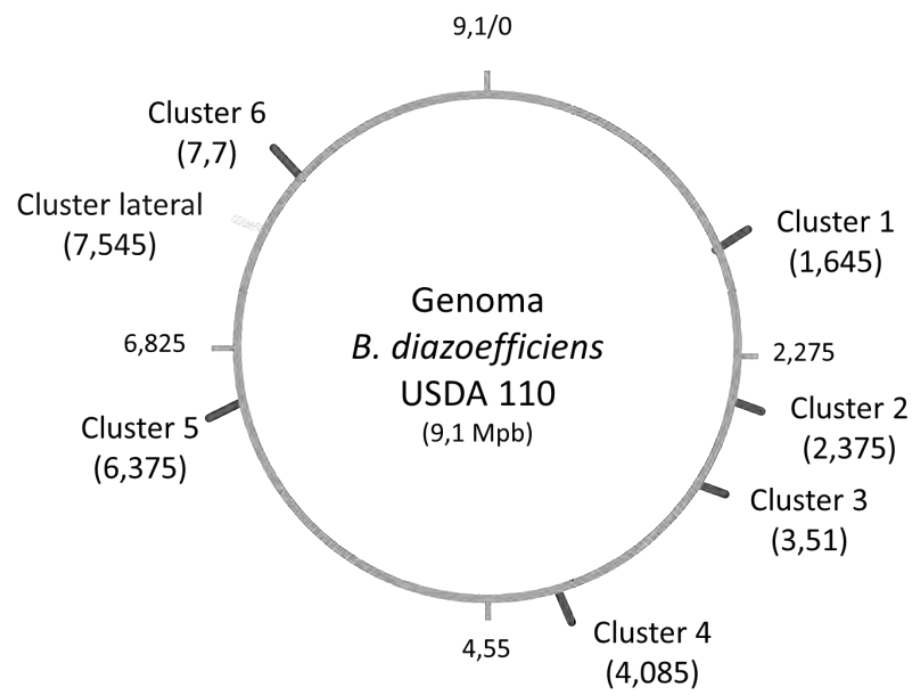

Figura III.1 - Esquema del cromosoma de B. diazoefficiens USDA 110. La Figura representa el genoma y las posiciones de los diferentes clusters de genes asociados a los sistemas de flagelos. Los clusters relacionados al sistema del flagelo subpolar se numeran del 1 al 6 ordenados de acuerdo a la posición en que aparecen en el cromosoma. Entre paréntesis se encuentra la ubicación en megapares de bases (Mpb). Modificado de Kanbe y col. (2007). 


\section{III.2 Anotación funcional de los posibles clusters relacionados al sistema del flagelo subpolar}

Con el fin de caracterizar los clusters que codifican el sistema del flagelo subpolar y establecer un modelo regulatorio de esta estructura, revisamos y analizamos nuevamente la anotación de cada uno de los genes que realizaron Kanbe y col. en 2007. Para ello, elaboramos una tabla con todos los genes y sus posibles funciones, basados en las anotaciones previas, como así también las posteriores que figuraban en la base de datos IMG (ver Materiales y Métodos). En los casos en que no pudimos determinar una función por similitud de secuencia, se realizaron búsquedas por Blast o mediante caracterización de dominios funcionales, cuya metodología general se encuentra detallada en Materiales y Métodos.

En la Tabla III.1 se indican los genes, las proteínas putativas y su función, y se presenta la organización génica de cada uno de los clusters en la Figura III.2. Los clusters se numeraron de manera ascendente siguiendo el orden en que están localizados en el cromosoma.

Tabla III.1 - Listado de genes en los seis c/usters que podrían ser parte del sistema del flagelo subpolar de $B$. diazoefficiens.

\begin{tabular}{|c|c|c|c|}
\hline Cluster & Locus_tag & gen & Función propuesta de la proteína \\
\hline \multirow{2}{*}{1} & bll1510 & $\operatorname{mot}_{1}$ & Motor \\
\hline & bll1511 & $\operatorname{mot}_{1}$ & Motor (hipotética) \\
\hline \multirow{10}{*}{2} & blr2191 & chpt & Phosphorelay de CtrA \\
\hline & blr2192 & cheA & Quimiotaxis \\
\hline & blr2193 & chew & Quimiotaxis \\
\hline & blr2194 & cher & Quimiotaxis \\
\hline & blr2195 & cheB & Quimiotaxis \\
\hline & blr2196 & cheR & Quimiotaxis \\
\hline & blr2200 & ctrA & Regulador de respuesta \\
\hline & blr2201 & flil & ATP-sintasa SSTIII FliHIJ \\
\hline & blr2202 & flis & Proteína de exportación SSTIII FliHIJ \\
\hline & bll2207 & flhA & SSTIII \\
\hline \multirow{5}{*}{3} & blr3695 & flaA & Flagelina \\
\hline & blr3696 & fliD & Cap del filamento \\
\hline & blr3697 & flis & Chaperona flagelina \\
\hline & blr3698 & --- & Proteína hipotética \\
\hline & blr3699 & $f l g D_{3}$ & Cap del gancho \\
\hline
\end{tabular}




\begin{tabular}{|c|c|c|c|c|}
\hline & blr3700 & $f l g E_{3}$ & Gancho & G \\
\hline & bsr3701 & -- & Proteína hipotética & \\
\hline & blr3702 & -- & Proteína hipotética & \\
\hline & blr3703 & $\mathrm{flgK}_{3}$ & Unión gancho-filamento & G \\
\hline & blr3704 & $f l g L_{3}$ & Unión gancho-filamento & G \\
\hline & blr3800 & pomA & Motor & $\mathbf{M}$ \\
\hline & blr3801 & pomB & Motor & $\mathbf{M}$ \\
\hline & bll5808 & cckA & Phosphorelay de CtrA & $R$ \\
\hline & bll5809 & flhB & SSTIII & $\mathbf{S}$ \\
\hline & bll5810 & fliR & SSTIII FliOPQR & S \\
\hline & bll5811 & fliQ & SSTIII FliOPQR & S \\
\hline & bll5812 & fliE & Bastón proximal & B \\
\hline & bll5813 & $f / g C$ & Bastón proximal & B \\
\hline & bll5814 & $f l g B$ & Bastón proximal & B \\
\hline & blr5815 & flio & SSTIII FliOPQR & $\mathbf{S}$ \\
\hline & blr5816 & fliP & SSTIII FliOPQR & $\mathbf{S}$ \\
\hline & bll5822 & & Proteína hipotética & \\
\hline & bll5823 & motE & Posible chaperona & \\
\hline & bll5824 & & Proteína hipotética & \\
\hline & bll5825 & flim & Switch Anillo C & A \\
\hline & bll5826 & fliL & Motor & M \\
\hline 5 & blr5827 & $f l g F$ & Bastón proximal & B \\
\hline 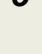 & blr5828 & $f l g G$ & Bastón distal & B \\
\hline & blr5829 & $f \lg A$ & Anillo P & A \\
\hline & blr5830 & $f l g H$ & Anillo L & A \\
\hline & bll5837 & flix & Regulador & $\mathbf{R}$ \\
\hline & blr5838 & flgl & Cap del bastón & B \\
\hline & blr5839 & flgJ & Hidrolasa del peptidoglicano & B \\
\hline & bll5842 & flaFs & Regulador & $\mathbf{R}$ \\
\hline & bll5843 & flic1 & Flagelina & $\mathbf{F}$ \\
\hline & bll5844 & flic2 & Flagelina & $\mathbf{F}$ \\
\hline & bll5845 & flic3 & Flagelina & $\mathbf{F}$ \\
\hline & bll5846 & flic4 & Flagelina & $\mathbf{F}$ \\
\hline & blr5847 & flbTs & Regulador & $\mathbf{R}$ \\
\hline & bll5852 & $f / g L_{5}$ & Unión gancho-filamento & G \\
\hline & bll5853 & $\mathrm{flgK}_{5}$ & Unión gancho-filamento & G \\
\hline & bll5854 & $f l g E_{5}$ & Gancho & G \\
\hline
\end{tabular}




\begin{tabular}{|c|c|c|c|c|}
\hline \multirow{8}{*}{6} & blr6996 & flik & Control gancho & $\mathbf{G}$ \\
\hline & blr6997 & $f l g D_{6}$ & Cap del gancho & G \\
\hline & blr6998 & scip & Regulador de CtrA & $\mathbf{R}$ \\
\hline & blr6999 & fliF & Rotor Anillo MS & A \\
\hline & blr7000 & fliG & Anillo C & A \\
\hline & blr7001 & fliH & SSTIII FliHIJ & $\mathbf{s}$ \\
\hline & blr7002 & fliN & Anillo C & A \\
\hline & blr7003 & $f l b D$ & Regulador & $\mathbf{R}$ \\
\hline
\end{tabular}

Los colores a la derecha representan las distintas subestructuras del flagelo, a saber:

$\mathbf{A}$ : anillos del cuerpo basal $\mathbf{B}$ : bastón $\mathbf{F}$ : filamento $\mathbf{G}$ : gancho $\mathbf{M}$ : motor $\mathbf{Q}$ : quimiotaxis $\mathbf{R}$ : regulador S: SSTIII. Los genes parálogos se encuentran discriminados con un subíndice que indica el número del cluster en el que se encuentran. Los genes reguladores tienen el subíndice "s" que representa el sistema flagelar subpolar.

Los genes de los distintos clusters presentan una distribución heterogénea y aparentemente aleatoria respecto de la subestructura flagelar que codifican. Es decir, aquellos genes que codifican las proteínas que forman parte de la misma subestructura no siempre se encuentran ubicados en el mismo operón y/o cluster. Un ejemplo de ello es el sistema de secreción tipo III (SSTIII), que está compuesto por las proteínas codificadas por fliHIJ, fliOPQR, flhA y flhB. Este sistema requiere de todos sus componentes para ejercer su función (Deng et al., 2017), pero cada uno de estos genes o pequeños grupos de genes, se ubican en clusters diferentes, en lugar de presentarse en un entorno génico que facilite su expresión conjunta a partir de un solo promotor. Sin embargo, cuando observamos en detalle este fenómeno, encontramos que los componentes del SSTIII poseen un orden que podría estar relacionado con la cantidad de monómero necesario de cada proteína, para formar el complejo funcional. Así, encontramos que FliQR y FlhB (que se encuentran en el mismo operón) se necesitan en cantidades iguales. En cambio, la cantidad de monómeros de FliP requerida es 5 veces mayor y de FlhA 7-9 veces más (Deng et al., 2017). En ambos casos, estas proteínas se encuentran codificadas por genes que se encuentran en operones independientes. Esta misma distribución se observó con otros genes que codifican proteínas estructurales que conformarían parte del bastón y del gancho flagelar (Ver referencia de colores en la Tabla III.1). Esta podría constituir una de las razones por las que los diferentes componentes del flagelo se encuentran distribuidos en diferentes clusters. 
Cluster 1

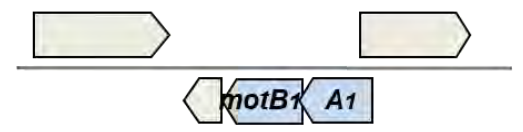

Cluster 2

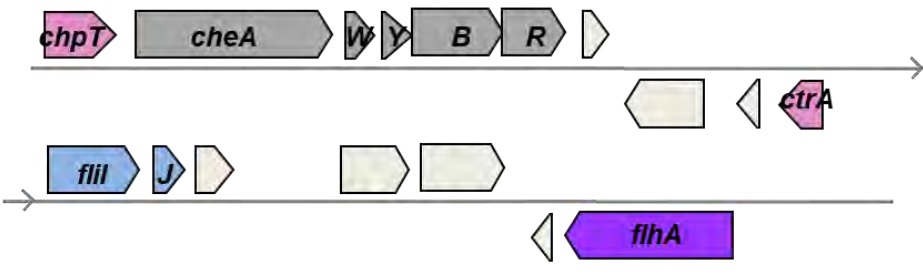

Cluster 3

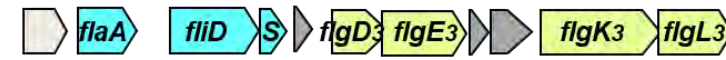

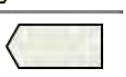

Reguladores

SSTIII fliHIJ

SSTIII fliOPQR

SSTIII fIhAB

Anillos

$\square$ Motor

Bastón

Gancho

Cluster 4

$\square$ pomA $B$

Cluster 5
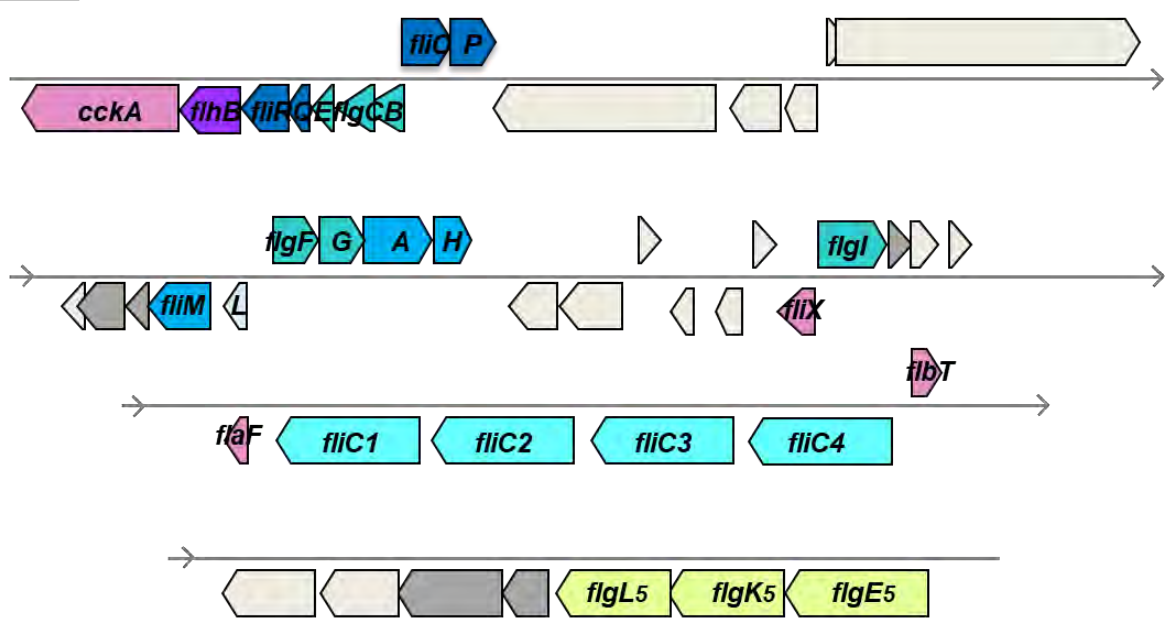

\section{Cluster 6}

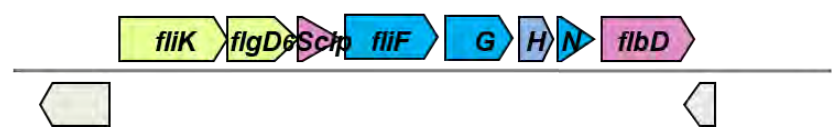

Figura III.2 - Organización genómica de losclusters que contienen genes flagelares estructurales y regulatorios que podrían formar parte del sistema del flagelo subpolar de $\boldsymbol{B}$. diazoefficiens. Los distintos colores indican la subestructura del flagelo en la que participaría cada proteína codificada por estos genes. 


\section{III.3 Búsqueda de posibles genes regulatorios de la síntesis del sistema del flagelo subpolar}

El cluster 5 representa el cluster con mayor número de genes flagelares. Entre ellos se encuentran los genes que codifican las cuatro flagelinas que conforman su filamento, las cuales fueron identificadas experimentalmente como parte del flagelo subpolar (Kanbe et al., 2007; Althabegoiti et al., 2011; Quelas et al., 2016a). Esto indica que el cluster es funcional y que los demás genes que lo componen podrían estar relacionados con otras estructuras del mismo sistema. Sin embargo, a pesar de que este cluster está formado por al menos 29 genes flagelares ${ }^{1}$, el mismo no codifica todas las proteínas necesarias para construir un flagelo funcional. Esto deja abierta la posibilidad que los otros clusters más pequeños estén también involucrados en la síntesis de este flagelo. Ello no constituye una particularidad de Bradyrhizobium, ya que, en diversas bacterias, los genes que codifican las estructuras flagelares están particionados en un número variable de clusters (Smith y Hoover, 2009).

En el estudio realizado por Kanbe y col. (2007) no lograron identificar genes regulatorios basando su búsqueda en el modelo de $E$. coli. Con el fin de relacionar los demás clusters con el sistema del flagelo subpolar, realizamos búsquedas de posibles reguladores de su síntesis, basándonos en otros modelos regulatorios conocidos. (Capítulo 1.3.3). Como esperábamos, la búsqueda de los reguladores homólogos a FlhDC o FliA $\left(\sigma^{28}\right)$-FlgM, que controlan la síntesis en E. coli y Salmonella, resultó infructuosa. Por otro lado, el regulador maestro descripto en $E$. meliloti, Rem, tiene su contraparte en $B$. diazoefficiens dentro del cluster del flagelo lateral. La función de esta proteína como regulador maestro del sistema flagelar lateral fue demostrada en trabajos previos y se descartó su participación sobre la regulación del sistema subpolar, debido a que el mutante que carece de este regulador maestro presentó el flagelo subpolar intacto (Mongiardini et al., 2017). No encontramos además ninguna otra copia extra homóloga a rem en el genoma de $B$. diazoefficiens. Por esta razón el sistema regulatorio mediante dichos reguladores ha sido descartado para el análisis en este trabajo de Tesis. De esta manera, continuamos la búsqueda utilizando las secuencias de los reguladores descriptos en C. crescentus, V. cholerae, Aeromonas hydrophila y $P$. aeruginosa, lo cual nos permitió identificar varios candidatos presentes en los diferentes clusters que podrían estar asociados a las funciones regulatorias del flagelo subpolar.

En primer lugar, pudimos encontrar un regulador de respuesta de sistemas de dos componentes codificado en blr2200, ubicado en el cluster 2 con alta similitud al regulador CtrA presente en la gran mayoría de las $\alpha$-Proteobacterias (Brilli et al., 2010),

\footnotetext{
${ }^{1}$ El cluster contiene 46 genes de los cuales sólo 29 parecerían ser genes flagelares y los genes restantes no estarían relacionados con la síntesis del flagelo subpolar.
} 
y el cual ha sido descripto como regulador maestro del flagelo en algunas de ellas como por ejemplo en $C$. crescentus, Sphingomonas melonis, Magnetospirillum magneticum, Rhodobacter capsulatus (Lang y Beatty, 2002; Laub et al., 2002; Greene et al., 2012; Francez-Charlot et al., 2015). También pudimos identificar otro regulador de respuesta dependiente del factor $\sigma^{54}$ en blr7003, ubicado en el cluster 6 . Dentro de los diferentes modelos regulatorios conocidos, existen varias proteínas dependientes de $\sigma^{54}$ entre las que encontramos reguladores de clase I (FleQ/FIrA en $P$. aeruginosa o $V$. cholerae) o de clase II (FIbD en C. crescentus, Azospirillum brasilense, V. cholerae y P. aeruginosa).

Dentro del cluster 5 también encontramos varios posibles genes regulatorios. Pudimos identificar una proteína pequeña, similar a FliX codificada en bll5837, y que fue descripta como modulador de la actividad del regulador FlbD en $C$. crescentus. Además, encontramos un par regulador FlbT-FlaF, caracterizado en los géneros Ensifer, Brucella y Caulobacter como responsable de la regulación post-transcripcional de las flagelinas (Capítulo 1.3.3). Por último, identificamos una histidina quinasa similar a CckA (Angelastro et al., 2009), probablemente involucrada en la fosforilación de CtrA, también asociada al cluster 5 .

La presencia de estos reguladores putativos en cada uno de estos clusters permitió suponer que los mismos podrían codificar estructuras involucradas en la construcción y normal ensamblaje del sistema flagelar subpolar de $B$. diazoefficiens. Entre todos los modelos regulatorios conocidos hasta la fecha encontramos cinco genes regulatorios homólogos a los descriptos para el modelo de regulación de $C$. crescentus (CtrA/FlbDFliX/FlbT-FlaF) en los clusters 2, 5 y 6 . Estos datos bioinformáticos indicarían que el flagelo subpolar en nuestro modelo de estudio podría regularse de manera similar al descripto en $C$. crescentus. Esta hipótesis será abordada en los capítulos siguientes.

Los clusters 1, 3 y 4 no presentan genes reguladores. Sin embargo, en los clusters 1 y 4 se pudieron identificar proteínas duplicadas relacionadas al motor (MotAB/ PomAB), que no se encuentran en ninguno de los otros clusters mencionados anteriormente. Ello indicaría que al menos algunos de estos genes deberían formar parte del sistema subpolar, ya que estos componentes son estrictamente necesarios para formar un flagelo funcional.

Finalmente, en el cluster 3 identificamos un marco de lectura abierto (blr3694) que codifica un factor $\sigma$ alternativo extracelular que podría desempeñar funciones similares al factor alternativo $\sigma^{28}$ de $E$. coli, a pesar de no presentar similitud de secuencia con este último. Además, en este cluster también se encuentran genes duplicados que codificarían la estructura del gancho (flgDEKL). Adicionalmente, hallamos genes que se encuentran en copia única como son fliD, que codifica la proteína Cap del filamento, flis que codifica una chaperona de flagelinas, y un gen que codificaría una posible flagelina de tipo flaA (274 aa) mucho más pequeña que las cuatro flagelinas subpolares flic1234 (757-763 aa) del cluster 5 (Kanbe et al., 2007; Althabegoiti et al., 2008). 
En resumen, nuestro análisis sugiere que casi todos los clusters (exceptuando posiblemente alguno del motor) estarían a priori involucrados en la regulación de la síntesis del sistema del flagelo subpolar.

\section{III.4 Genes parálogos que codificarían componentes estructurales del flagelo subpolar en B. diazoefficiens}

En otras bacterias con sistemas flagelares duales se ha descripto la presencia de genes duplicados que codifican proteínas con idéntica función (genes parálogos). Sin embargo, generalmente cada proteína participa de la formación de un único sistema flagelar y no intervienen en el otro sistema. Es decir, la proteína de un sistema flagelar no complementa la función en el otro sistema. En B. diazoefficiens identificamos genes parálogos dentro de los clusters de cada uno de los sistemas flagelares para la mayoría de los genes flagelares, aunque también encontramos algunos genes que se encontraban en más de dos copias. Es decir, identificamos ciertos genes estructurales que se encuentran triplicados en el genoma (una copia en el cluster del flagelo lateral y dos copias en otra región del genoma). Inicialmente hemos podido identificar al menos ocho genes que parecen estar en más de dos copias. Estos codifican las proteínas FlgE, componente principal del gancho; FlgD proteína cap del gancho; FlgL proteína adaptadora del gancho (al igual que FlgK o FlaN); y las proteínas del motor PomAB y MotAB. Algunos de los genes que codifican estas proteínas podrían ser funcionales mientras que otros no, o podrían reemplazar las funciones cuando la otra copia se pierde.

En el 2016, Cuklina y colaboradores realizaron estudios transcriptómicos sobre $B$. diazoefficiens en vida libre y dentro de nódulos de soja, los cuales podrían aportar indicios acerca de la funcionalidad de estos clusters duplicados (Figura III.3). A partir de los datos de este trabajo se analizaron los niveles de transcripto de algunos de los clusters involucrados en la síntesis del flagelo subpolar. En la Figura III.3 se muestran los gráficos donde los niveles de las barras del eje $Y$ representan las veces que se leyeron los transcriptos de cada gen en los experimentos de secuenciamineto de cDNA (Cuklina et al., 2016). Este análisis mostró que los genes codificados en el cluster 3 (que contienen los genes $f\left(g D E K L_{3}\right.$ ) poseen niveles de transcripción muy bajos, al menos en las condiciones en las cuales se realizó el experimento (aunque no difieren mucho de las condiciones utilizadas en nuestros ensayos) (Figura III.3-C). Esto podría indicar que estos genes simplemente tienen una baja tasa de transcripción o podría tratarse de genes inactivos o no funcionales. Si comparamos estos valores con los niveles de transcripción que se observaron para la otra copia del gen flg $D_{6}$ codificada en el cluster 6 (Figura III.3-D) no difieren mucho (también es bajo). Sin embargo, cuando se comparan los niveles de transcripto de las copias que codifican el componente 
principal del gancho $\left(f l g E_{3}\right.$ y $f l g E_{5}$ presentan una diferencia considerable. Esta última se transcribe en un nivel mucho mayor que la primera (Figura III.3-E). Una explicación a esta diferencia podría ser que, FlgD, que es la proteína cap del gancho, se requiere en una cantidad mucho menor comparada con FlgE, que es su proteína mayoritaria y se requiere en grandes cantidades. Todo esto, sugiere una falta de funcionalidad del cluster 3, al menos en las condiciones analizadas. No podemos descartar que este cluster tome proponderancia en caso de que alguna función de otro sea eliminada. El mismo análisis puede repetirse para las proteínas MotAB (cluster 1) y PomAB (cluster 4). Para estos, los niveles de transcripción medidos parecen tener niveles similares $y$ no puede hacerse ninguna inferencia funcional (Figura III.3-AB).

A

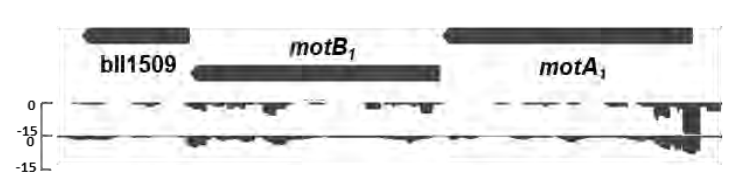

C

15
0
15
0
0

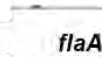

D

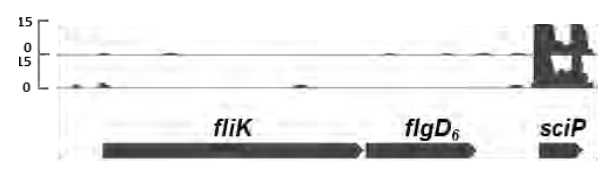

E
B

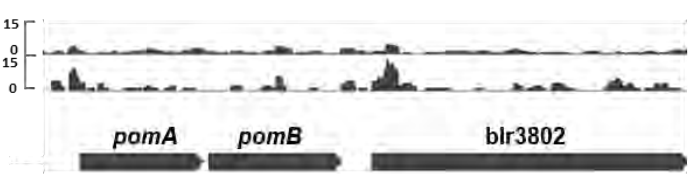

$\mathrm{fgE}_{3} \stackrel{\mathrm{bSr} 3701}{\mathrm{blr3702} \quad \mathrm{flgK}_{3}}$

$\mathrm{flg}_{3}$

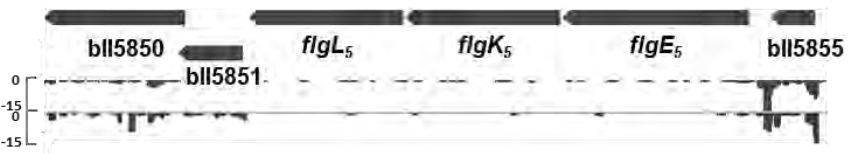

Figura III.3 - Lecturas de secuenciamiento de CDNA de los genes parálogos del motor y el gancho de $\boldsymbol{B}$. diazoefficiens. Los ejes de cada gráfico indican las cantidades de lecturas de cDNA de $B$. diazoefficiens en vida libre (medio PSY-ara) para A. $\operatorname{motAB}_{1}$ B. pomAB C. flgDEKL $L_{3}$ D. flgD $\mathrm{D}_{6} \mathbf{E}$. flgEKL. Datos obtenidos de Cuklina y col. (2016).

A priori, este primer análisis bioinformático no aporta información suficiente como para hacer una predicción precisa acerca de cuáles clusters u operones serían funcionales. Por ello, y con el fin de profundizar este análisis y realizar una posible asignación de función de estos genes parálogos, realizamos un análisis bioinformático y filogenético más profundo, el cual se mostrará a continuación.

\section{III.4.1 Análisis bioinformático de los componentes estructurales duplicados en B. diazoefficiens}

Las proteínas del motor denominadas genéricamente como MotA y MotB son proteínas de membrana que forman parte del estator del motor flagelar. Estas 
proteínas forman un canal entre el periplasma y el citosol, a través del cual se translocan iones $\left(\mathrm{H}^{+}\right.$o $\left.\mathrm{Na}^{+}\right)$cuyo flujo genera un cambio conformacional en MotA, que es transferido a una proteína del cuerpo basal (FliG), generando así la fuerza de rotación. En el cluster 1 encontramos una copia de los genes $\operatorname{mot} A-\operatorname{mot} B$, y en el cluster 4 una copia de pomA-pomB. Los genes pom son homólogos a los genes mot y su nombre varía debido a la nomenclatura utilizada para los genes del motor en $V$. alginolyticus. En esta bacteria las proteínas motoras usan $\mathrm{Na}^{+}$como generador de la fuerza motriz. En algunas bacterias, se han encontrado dos o más copias de los genes mot y/o pom, las cuales son utilizadas de manera alternativa o incluso formando heteropolímeros, para formar el motor en estos microorganismos (Toutain et al., 2005; Paulick et al., 2009; Wilhelms et al., 2009; Baker y O’Toole, 2017;).

Tabla III.2 - Predicción de dominios de las proteínas MotAB/PomAB del motor de $B$. diazoefficiens (codificadas en tres genes parálogos).

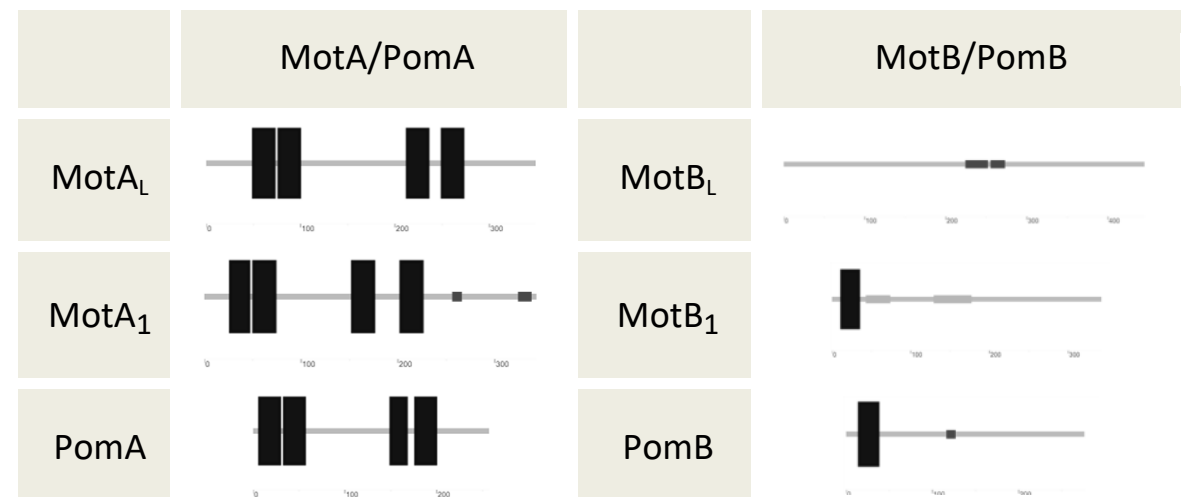

Los recuadros negros muestran dominios transmembrana. Los recuadros pequeños representan zonas de baja complejidad.

$\operatorname{Mot}_{L}(B \mid l 6882), M_{L}$ (Bll6862), MotA (Bll1511), MotB $_{1}$ (Bll1510), PomA (BIr3800)

PomB (B|r3801)

En la Tabla III.2 se muestra la predicción de dominios para las proteínas MotAB y PomAB presentes en $B$ diazoefficiens. A partir de este momento denominaremos Mot $_{L}$ y $\operatorname{Mot}_{L}$ a las copias presentes en el cluster lateral, y Mot $A_{1}$ y MotB ${ }_{1}$ a las copias presentes en el cluster 1.

Las tres copias de MotA/PomA presentan una organización de dominios similar, mientras que la organización de dominios de MotB/PomB solo se respeta entre las MotB $_{1}$ (BII1510) y PomB (BIr3801). Los alineamientos de secuencia entre las proteínas MotA/PomA y MotB/PomB muestran una gran variabilidad entre ellas, con algunas regiones conservadas (Anexo Figura Alll.1). La baja similitud de secuencia no nos brinda información suficiente que nos permita inferir una acción conjunta entre alguna de estas proteínas.

El análisis filogenético de las proteínas del motor (MotAB/PomAB) de $B$. diazoefficiens muestra que los motores del sistema de flagelos laterales se agrupan en un clado separado del que forman PomAB y $M_{0} A B_{1}$ (Figura III.4). Esto indicaría que 
estas últimas cuatro proteínas podrían estar actuando de manera coordinada en el motor del flagelo subpolar. Sin embargo, este análisis no es concluyente ya que el soporte de las diferentes ramas no es alto, a pesar de que el árbol se construyó con un boostrap de 1000 réplicas.

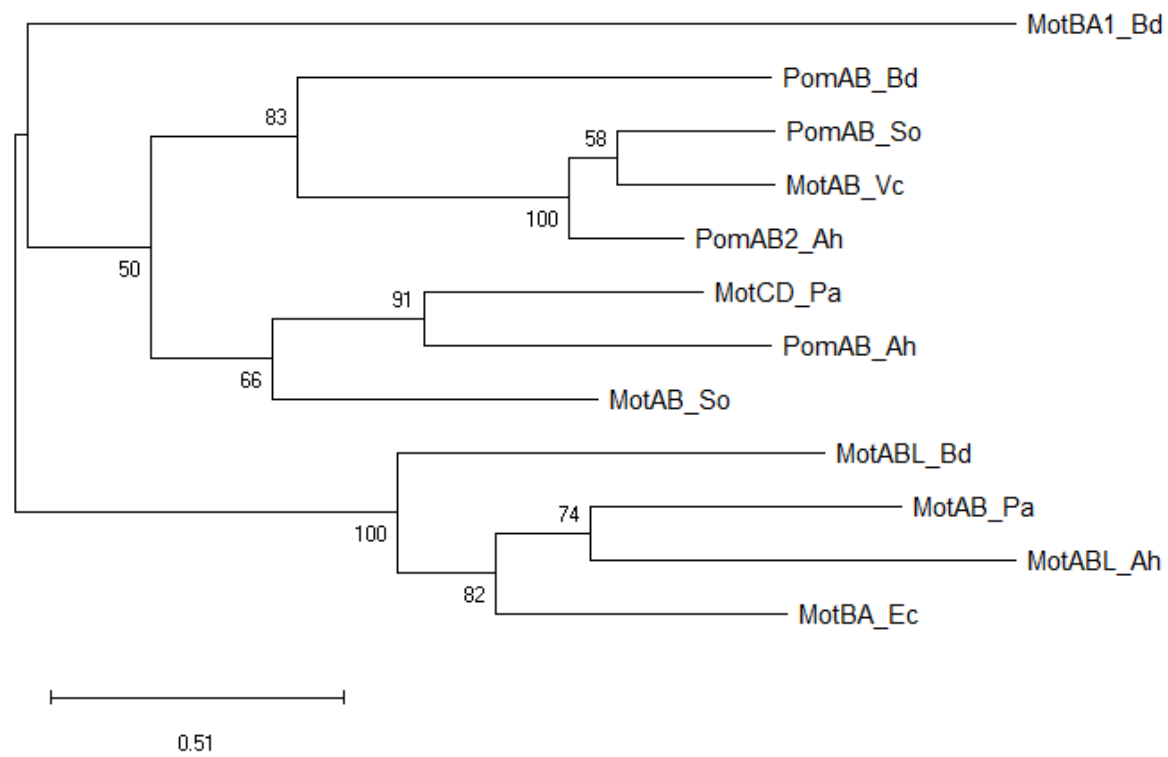

Figura III.4 - Arbol filogenético construido con las proteínas MotAB/PomAB de $B$. diazoefficiens USDA 110 y proteínas Mot/Pom de otras especies bacterianas con función conocida. El árbol se realizó con los pares de proteínas del motor concatenadas. Bd: B. diazoefficiens, So: Shewanella oneidensis, Vc: V. cholerae, Ah: A. hydrophila, Pa: P. aeruginosa, Ec: E. coli.

Por otro lado, analizamos los genes que codifican las proteínas del gancho flgDEKL. Para la proteína FlgE, componente mayoritario del gancho, encontramos una copia en el cluster del flagelo lateral, la cual denominaremos $\mathrm{FlgE}_{\mathrm{L}}$ (Bll6858) y otras dos copias denominadas $\mathrm{FlgE}_{3}$ (cluster 3, Bll3700) y $\mathrm{FlgE}_{5}$ (cluster 5, Bll5854). Las tres proteínas muestran una organización de dominios similar donde se pueden identificar los dominios del gancho $\mathrm{N}$ y C terminales (PF00460-PF06429) y un dominio interno característico FlaE (PF07559). En la Tabla III.3 se puede ver una representación de cada una de las proteínas con su organización de dominios. De este análisis podemos observar que la proteína $\mathrm{FlgE}_{5}$ presenta una región interna larga que no tiene un dominio definido y que le confiere mayor longitud con respecto a las otras dos proteínas. Debido a ello, la secuencia de $\mathrm{FlgE}_{3}$ alinea mejor con la proteína que se encuentra en el cluster del flagelo lateral (Anexo Figura Alll.2).

Cuando realizamos el análisis sobre las copias de FlgD, observamos que las tres proteínas muestran la misma organización de dominios, aunque cuando realizamos el alineamiento de secuencias observamos que existe una mayor similitud entre $\mathrm{FlgD}_{3}$ (Blr3699) y $\mathrm{FlgD}_{6}$ (Blr6997), mientras que la copia presente en el cluster del flagelo lateral, $\mathrm{FlgD}_{\mathrm{L}}$ (Bll6853) presenta una región que no alinea con ninguna de las dos proteínas. 
En el caso de FlgK (o FlaN), las tres proteínas alinean con un score similar aunque las proteínas $\mathrm{FlgK}_{3}$ y $\mathrm{FlgK}_{5}$ son más grandes que $\mathrm{FlgK}_{\mathrm{L}}$ (del flagelo lateral). Cuando observamos el árbol filogenético que brinda el servidor PhylomeDB para $\mathrm{FlgK}_{3}$ (Blr3703) observamos que las tres copias de FlgK de $B$. diazoefficiens aparecen en el mismo grupo, y por lo tanto este análisis no nos permite asociar ninguna de las copias del cluster 3 y 5 con alguno de los dos sistemas flagelares (Figura All.4).

Para FlgL en cambio, vemos que la proteína $\mathrm{FlgL}_{5}$ es considerablemente más grande que las otras dos y en el árbol filogenético se observa que la copia $\mathrm{FlgL}_{3}$ presente en el cluster 3 se encuentra conservada sólo en un grupo pequeño de bacterias.

Tabla III.3 - Predicción de dominios de las proteínas FlgE y FlgD del gancho flagelar de $B$. diazoefficiens (codificadas en tres genes parálogos).

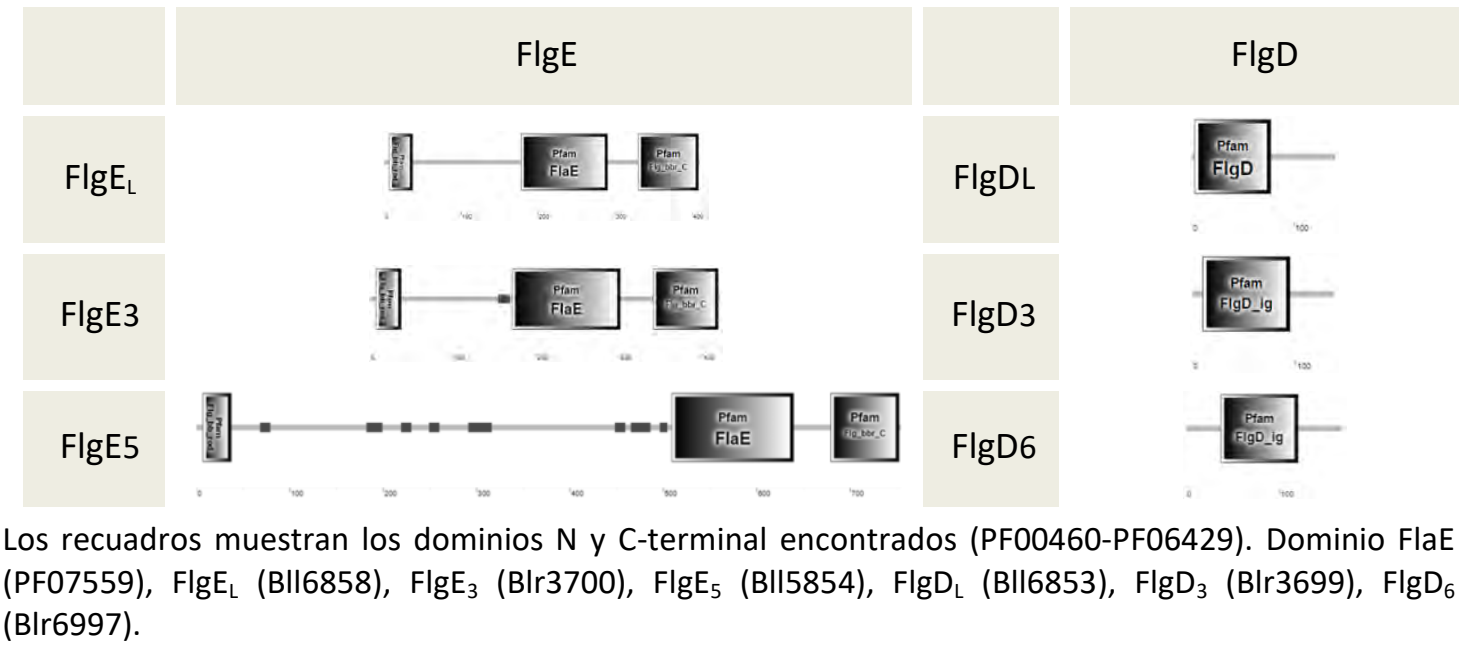

Tabla III.4 - Predicción de dominios de las proteínas FlgK y FlgL del gancho flagelar de $B$. diazoefficiens (codificadas en tres genes parálogos).

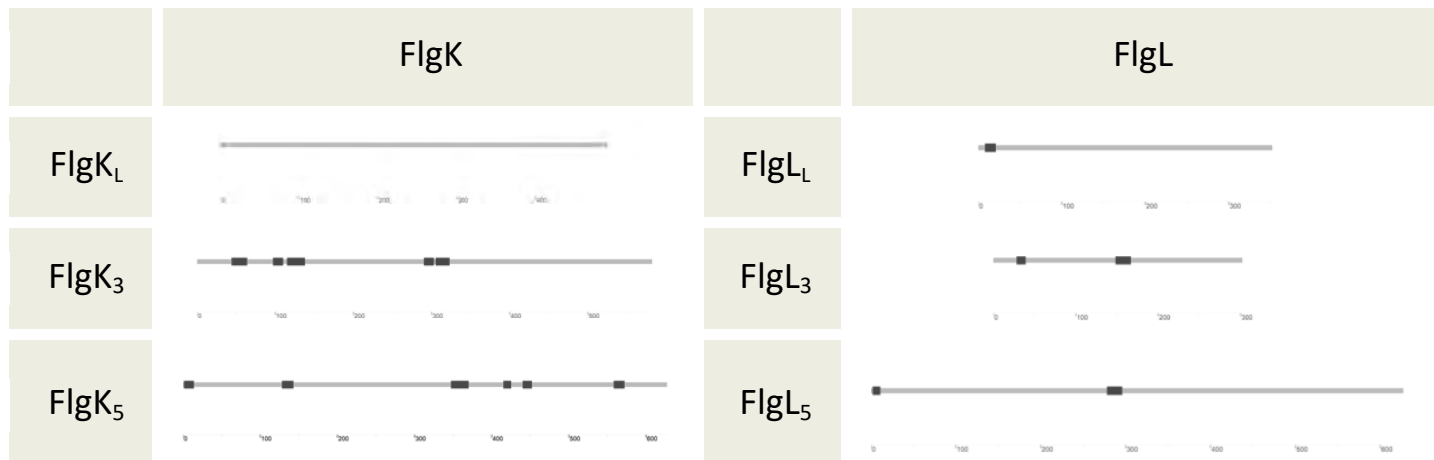

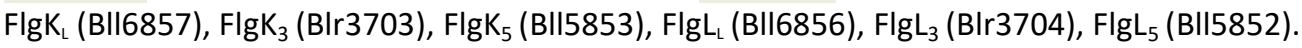

El análisis bioinformático que realizamos no fue suficiente para lograr asociar algunas de las proteínas MotAB o PomAB con alguno de los dos sistemas flagelares. En cambio, las proteínas del gancho ubicadas en el cluster 3 , parecerían asociarse más con el sistema de flagelos laterales, aunque algunas de ellas (como por ejemplo las tres FlgK) son muy similares entre sí. La presencia de una probable flagelina muy pequeña 
que no compone ninguno de los filamentos flagelares y los bajos niveles de transcripción de todos estos genes duplicados del cluster 3 parecerían indicar que este cluster no sería funcional en $B$. diazoefficiens USDA 110.

\section{III.4.2 Análisis de genes del motor: construcción de un mutante en motB (bll1510)}

Dado que el análisis bioinformático no fue suficiente para determinar las proteínas del motor que participan en la rotación del flagelo subpolar, decidimos estudiar las proteínas $M o t A B_{1}$ y PomAB mediante mutagénesis dirigida de los genes que las codifican.

Para estudiar la funcionalidad de $M o t A B_{1}$, realizamos una deleción del gen $\operatorname{mot}_{1}$ ubicado en bll1510. Para construir una cepa mutante en este gen realizamos una deleción de un fragmento codificante interno haciendo uso de dos sitios de restricción Sall y luego una doble recombinación homóloga (Figura III.5). El corte con Sall liberó un fragmento múltiplo de tres, por lo que la deleción mantuvo el marco de lectura evitando posibles efectos polares sobre el gen que se encuentra corriente abajo y codifica una probable acetiltransferasa.

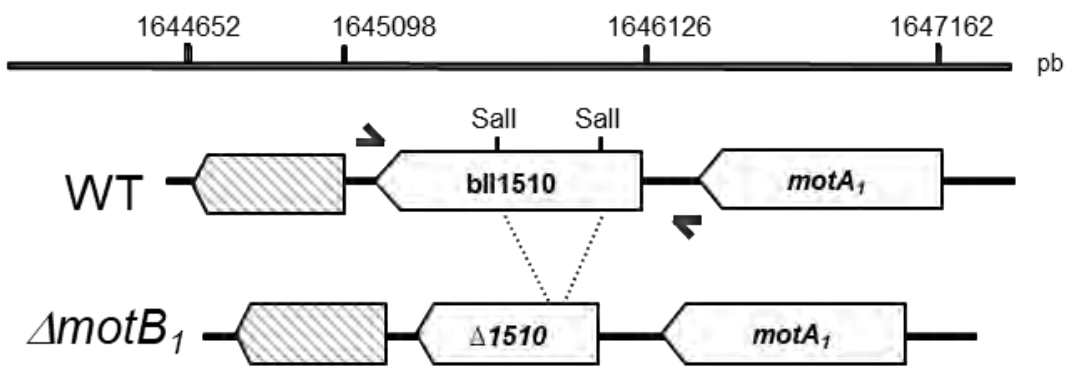

Figura III.5 - Mapa esquemático del gen bll1510 y genes vecinos (c/uster 1) que muestra el diseño utilizado para su mutagénesis. La estrategia consistió en amplificar el gen por PCR para luego delecionar un fragmento interno por digestión con la enzima Sall. Los símbolos rayados son genes que no guardan relación con ningún componente flagelar.

Para construir el plásmido necesario para realizar la deleción, amplificamos un fragmento del gen de $1.428 \mathrm{pb}$ a partir de ADN total de $B$. diazoefficiens con una enzima que deja extremos romos (Pfu) utilizando los primers 1510_Fw y 1510_Rv (entre las bases 1.644 .998 y 1.646 .425 ) (Figura III.6-A). Luego, clonamos el fragmento en un vector de entrada pBlueScriptSK(+) digerido previamente con la enzima Smal que también deja extremos romos, obteniendo el vector pBS::1510. Este vector fue chequeado utilizando la enzima Sall que libera dos fragmentos de 367 pb y 742 pb (Figura III.6-B). A posteriori, el fragmento fue subclonado en el plásmido pK18mobsacB utilizando las enzimas de restricción BamHI-HindIII, dando como resultado el plásmido pKsacB::1510. Este último se digirió con la enzima Sall, se purificó la banda de 6.406 pb 
de un gel de agarosa y se religó generando la construcción pKsacB:: $\triangle 1510$ (Figura III.6C), la cual lleva el gen bll1510 delecionado. Esta construcción fue chequeada por PCR utilizando los primers 1510_Fw y 1510_Rv (Figura III.6-D) y luego fue transferida por conjugación a $B$. diazoefficiens USDA 110 . La selección de recombinantes dobles delecionados en el fragmento deseado se realizó de acuerdo al protocolo general explicado en Materiales y Métodos. La diferenciación entre clones wild-type (WT) o mutantes se hizo por PCR utilizando primers externos a la zona de recombinación denominados Ext1510_Fw y Ext1510_Rv. Así, se seleccionaron aquellos que amplificaban un fragmento esperado de 905 pb (Figura III.6-G). La corroboración se realizó mediante secuenciación de este producto de PCR. La cepa mutante obtenida se llamó $\Delta m o t B_{1}$. 
A. Amplificación del fragmento 1510 blunt y clonado en el vector de entrada pBlueScriptSK(+).
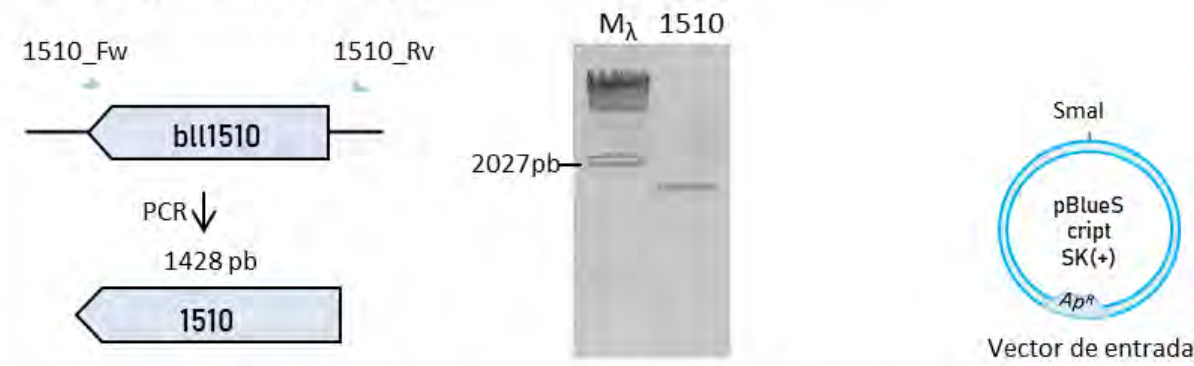

B. Chequeo por digestión de $p B S:: 1510$ con la enzima Sall y subclonado a pK18mobsacB utilizando los sitios HindIII-BamHI.
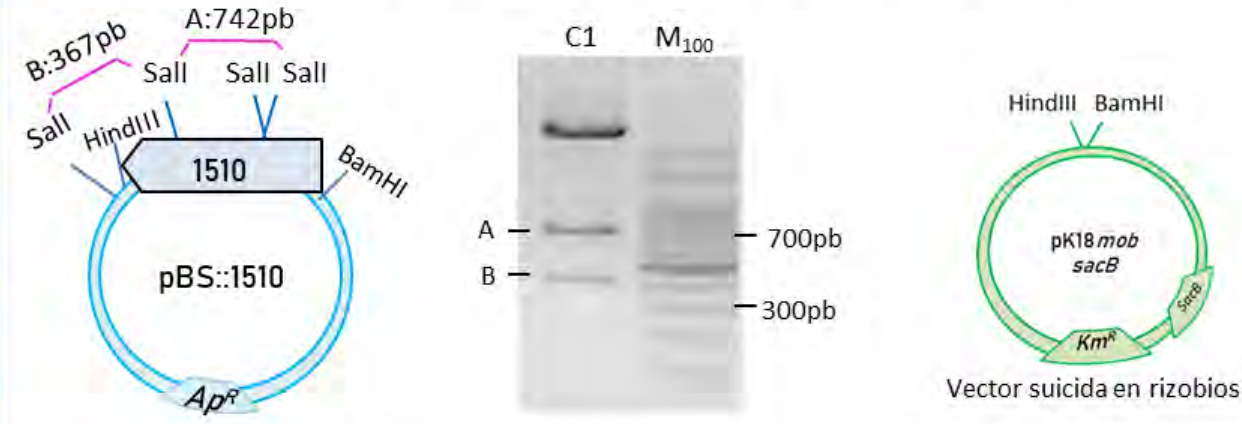

C. Chequeo por digestión de $p K S a c B: 1510$ con HindIII-BamHI (H-B), y posterior digestión con Sall y religado.
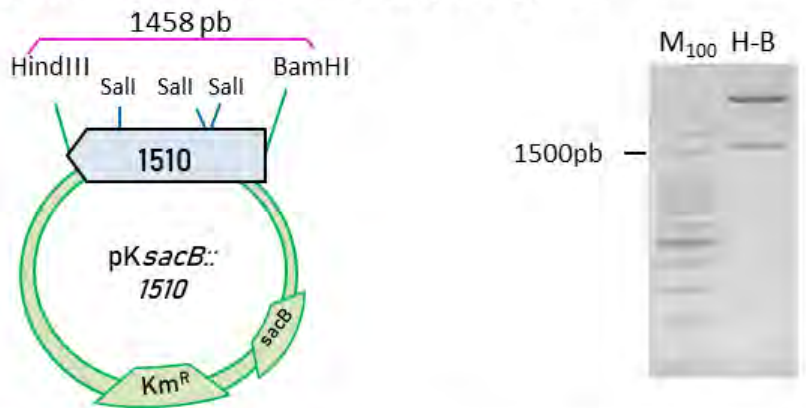

D. Chequeo por PCR con primers universales M13_Fw y M13_Rv.
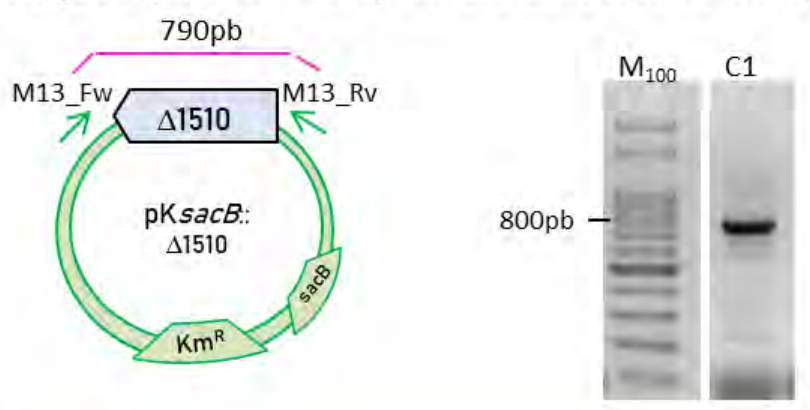

E. coli $\mathrm{DH} 5 \alpha$ 


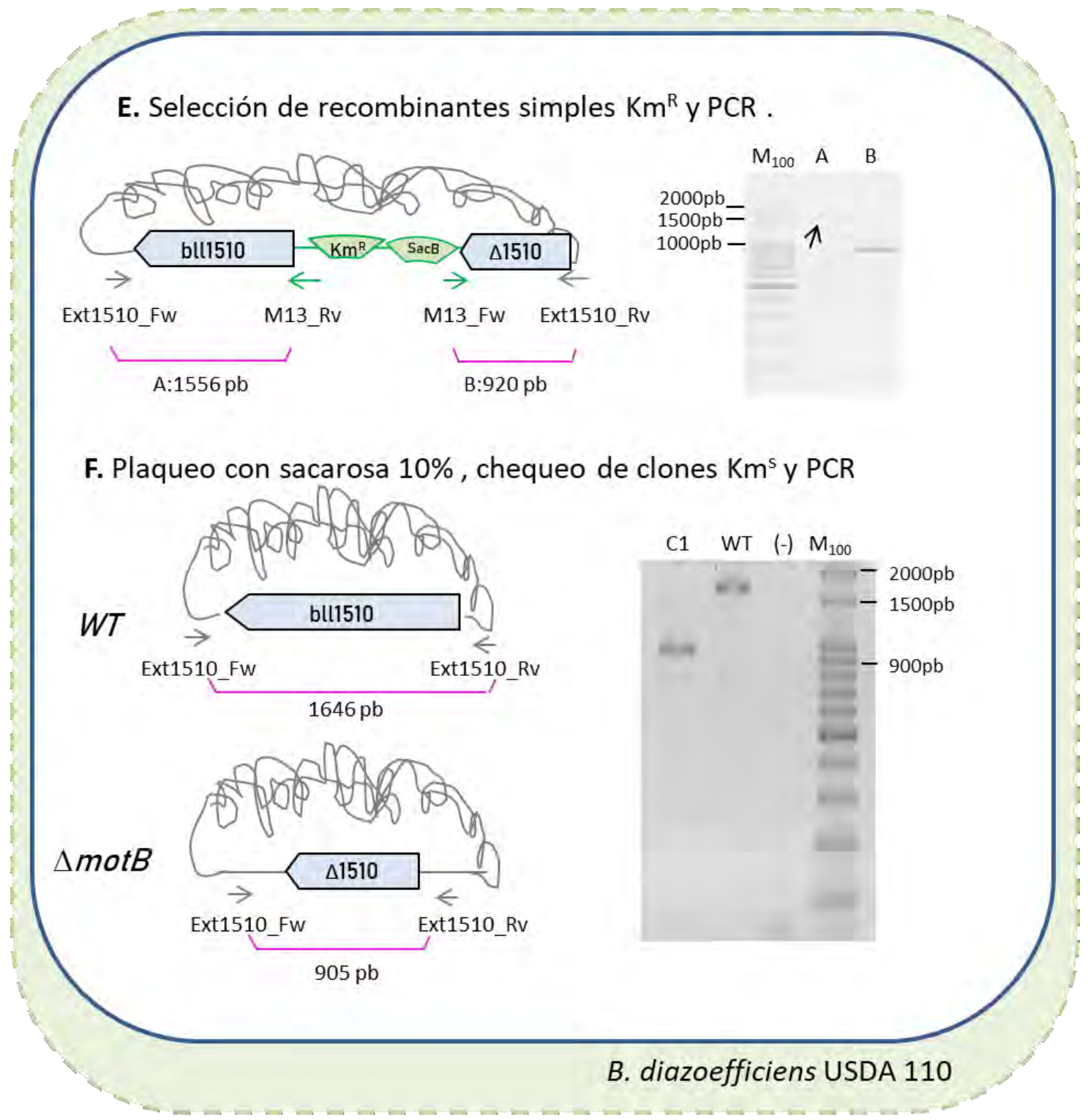

Figura III.6 - Esquema del clonado y selección de la cepa mutante de $B$. diazoefficiens $\triangle \boldsymbol{m o t}_{1}$. El gráfico con el recuadro amarillo representa los pasos de clonación para obtener el plásmido pKsacB:: $\triangle 1510$ en $E$. coli. El gráfico con el recuadro verde muestra un esquema del cromosoma de $B$. diazoefficiens WT y mutante con énfasis en el gen $\operatorname{mot}_{1}$ y su comprobación por PCR (gel de agarosa).

1510 representa el fragmento de bll1510 amplificado. En los geles de agarosa $\mathrm{M}_{100}$ indica el marcador de peso molecular de $100 \mathrm{pb}$. Con la letra $\mathrm{C}$ y un número se indican diferentes clones chequeados durante las construcciones por digestión con enzimas de restricción ( $B$ y C) o por PCR (D y F). WT indica el control con ADN de la cepa WT y (-) el control negativo con agua. s/d indica el plásmido sin digerir.

La caracterización inicial del mutante comprendió ensayos de aislamiento de flagelinas extracelulares de cultivos líquidos y movilidad en agar semisólido.

El perfil de proteínas extracelulares en el gel de poliacrilamida (Figura III.7-A) muestra que la cepa $\Delta$ motB $_{1}$ fue capaz de sintetizar flagelinas de alto peso molecular (subpolares) y de bajo peso molecular (laterales). Cuando analizamos la capacidad de natación en agar semisólido, no se observaron diferencias significativas entre la cepa WT y $\Delta m o t B_{1}$ sin embargo, esta última presentó un halo algo mayor que la cepa WT (Figura III.7-B). 
Para independizarnos del efecto que produce cada sistema flagelar sobre el otro en la natación y poder determinar si la mayor movilidad observada en $\Delta \operatorname{mot} B_{1}$ se acentuaba, decidimos delecionar las dos flagelinas del sistema de flagelos laterales (denominadas LafA12) o las cuatro flagelinas subpolares (denominadas FliC1234) sobre esta cepa. De esta manera se evaluó el efecto neto de la mutación de mot $B_{1}$ sobre cada uno de los sistemas flagelares. La doble mutante $\Delta \operatorname{mot} B_{1} \Delta$ flic, que solo tiene flagelos laterales y le falta $\operatorname{mot} B_{1}$, volvió a presentar una leve tendencia de mayor movilidad comparado con la cepa $\Delta f$ fiC (que solo tiene flagelos laterales). Hasta el momento, no hemos podido obtener la mutante $\operatorname{mot} B_{1}$ en la cepa $\Delta$ lafA (que solo presenta flagelo subpolar) para observar si la mutación en mot $B_{1}$ también genera un efecto similar sobre el flagelo subpolar.

A

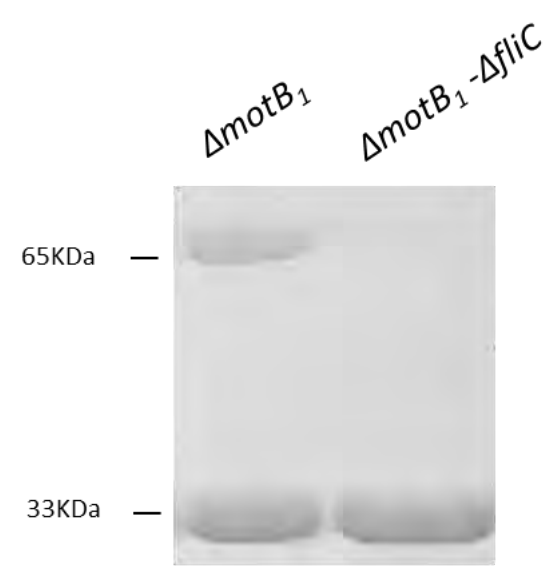

B
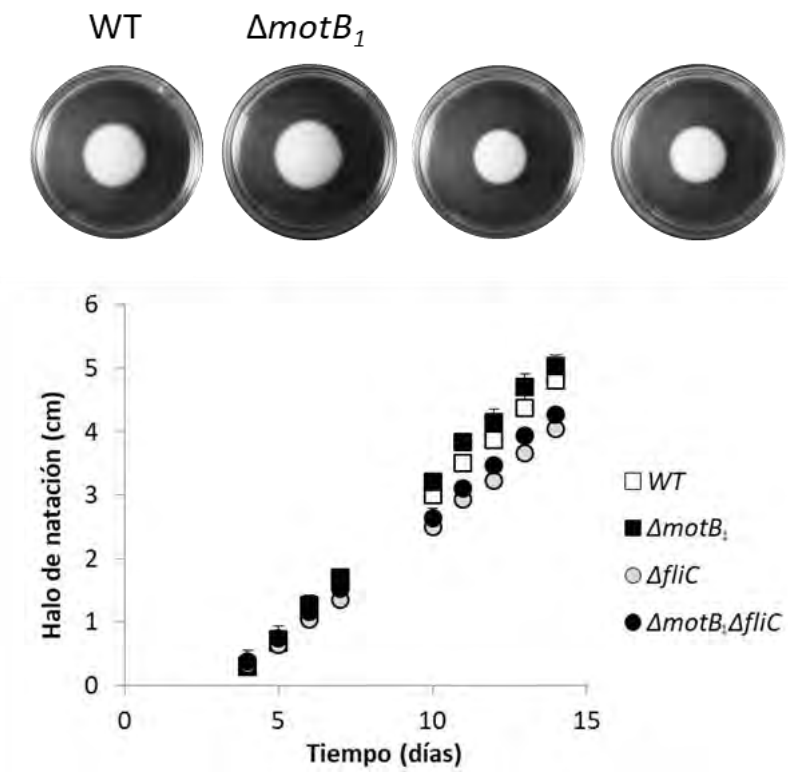

Figura III.7 - Perfil de flagelinas (A) y ensayos de movilidad en agar semisólido (B) de las cepas de $B$. diazoefficiens mutantes en mot $_{1}$. A. SDS-PAGE de flagelinas extracelulares de la cepa $\Delta m o t B_{1}$ y el doble mutante $\Delta m o t B_{1}-\Delta f l i C$. La banda de $65 \mathrm{kDa}$ representa las cuatro flagelinas subpolares (FliC1234) y la banda de 33kDa representa las dos flagelinas laterales (LafA12) B. Ensayo de natación en agar semisólido de la cepa wildtype (WT), $\Delta \operatorname{mot} B_{1}, \Delta$ flic y $\Delta$ motB $B_{1}-\Delta f l i C$. Se muestran fotos representativas de cada cepa en placas de Petri a los 10 días. Los halos de natación de tres réplicas técnicas fueron registrados en función de los días y graficados con el desvío estándar.

\section{III.4.3 Análisis de genes del gancho: construcción de un mutante en blr3699}

Para mutar los genes que se encuentran en el cluster 3 realizamos una mutación por inserción en el gen flgD3 (blr3699). Esta estrategia fue elegida de manera intencional debido a que, al interrumpir el primer gen del operón con un cassette que codifica una resistencia a un antibiótico, esperamos generar un efecto polar sobre la transcripción de los genes que se encuentran corriente abajo. 


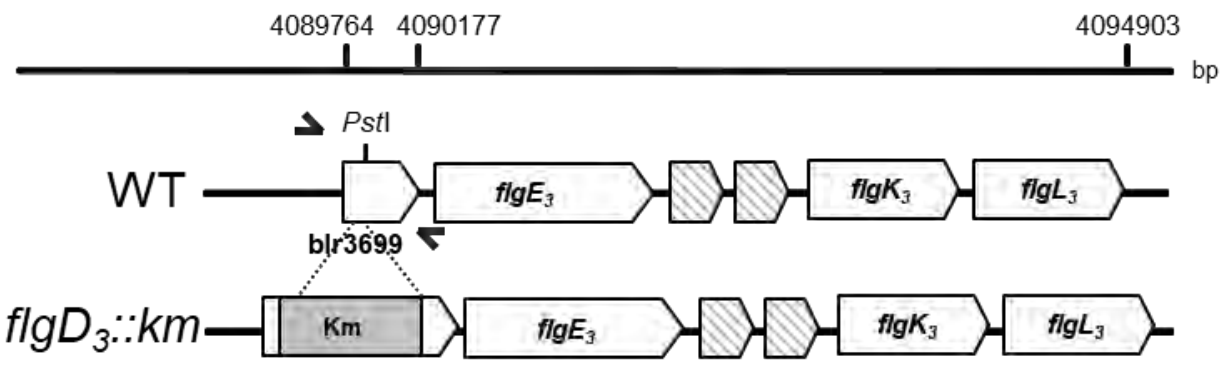

Figura III.8 - Mapa esquemático del gen blr3699 y genes vecinos (c/uster 3 ) que muestra el diseño utilizado para su mutagénesis. La estrategia consistió en amplificar el gen por PCR y clonar en el sitio Pstl que se ubica dentro del gen, un cassette de resistencia a Kanamicina $(\mathrm{Km})$. Los símbolos rayados son genes que no guardan relación con ningún componente flagelar.

Para obtener el vector necesario para la construcción del mutante, se amplificó el gen completo a partir de ADN total de B. diazoefficiens (entre las bases $4.089 .491 \mathrm{y}$ 4.090.219) con los primers 3699_FwX y 3699_RvH (725 pb). Este fragmento, digerido con las enzimas presentes en los primers, Xbal-HindIII, se clonó en el plásmido pG18mob2 generando la construcción pG::3699 (Figura III.9-A). Esta construcción fue chequeada por digestión utilizando las enzimas EcoRV-Pstl que liberan un fragmento de 910 pb. (Figura III.9-B). Luego, este vector se digirió con la enzima de restriccion Pstl que lleva el inserto y en el cual se clonó la resistencia a $\mathrm{Km}$ liberada del plásmido pUC4K, con la misma enzima de restricción y obtuvimos la construcción pG::3699::Km (Figura III.9-C). Este plásmido fue movido por conjugación a la cepa B. diazoefficiens USDA 110. Los clones mutantes se seleccionaron como se describió en Materiales y Métodos. Los posibles mutantes fueron chequeados utilizando la combinación de un primer externo a la zona de recombinación y un primer específico del cassette. Así, la amplificación con el par Ext3699_Fw/Km_Fw dio 828 pb y la del par Ext3699_Rv/Km_Rv dio 1.123 pb, siendo ambos tamaños los esperados de acuerdo con el análisis in silico (Figura III.9-D). Para corroborar la mutación, ambos fragmentos fueron secuenciados. La cepa obtenida fue denominada $f \lg D_{3}:: \mathrm{Km}$. 


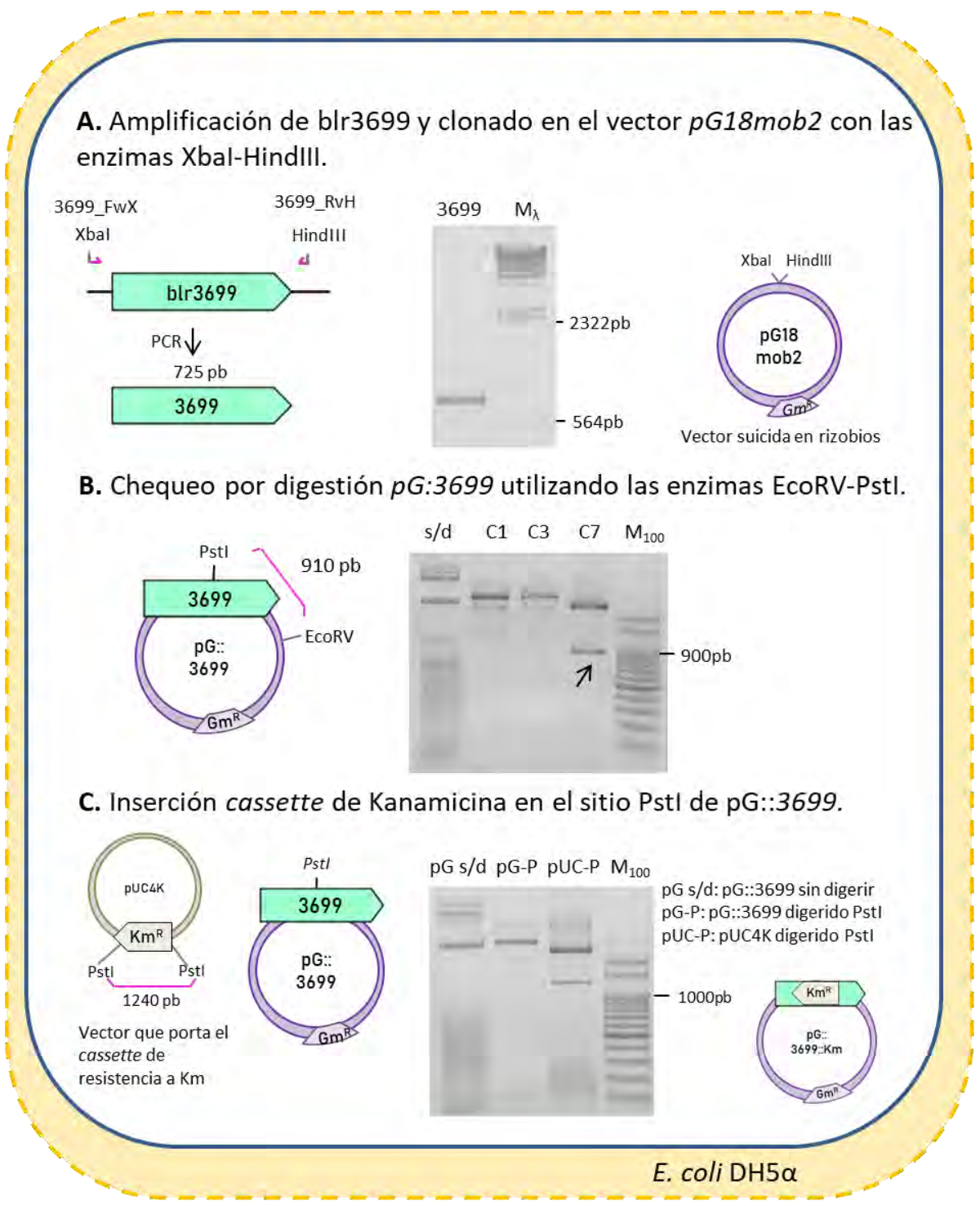

D. Selección de recombinantes dobles (colonias $\mathrm{Km}^{\mathrm{R}}$ ) y chequeos por PCR con primers externos.
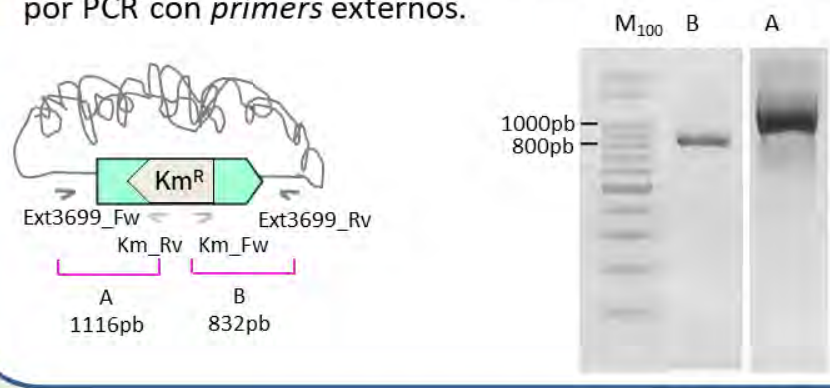

B. diazoefficiens USDA 110

Figura III.9 - Esquema del clonado y selección de la cepa mutante de B. diazoefficiens $f l g D_{3}:: K m$. El gráfico con el recuadro amarillo representa los pasos de clonación para obtener el plásmido pG::3699::Km en E. coli. El gráfico con el recuadro verde muestra un esquema del cromosoma de $B$. diazoefficiens mutante con énfasis en el gen $f_{l g} D_{3}$ y su comprobación por PCR (gel de agarosa).

3699 representa el fragmento de blr3699 amplificado. En los geles de agarosa $M_{100}$ y y $M_{\lambda}$ representan marcadores de peso molecular de $100 \mathrm{pb}$ o $\lambda$-HindlII respectivamente. Con la letra $\mathrm{C}$ y un número se indican diferentes clones chequeados durante las construcciones por digestión con enzimas de restricción (B). s/d indica el plásmido sin digerir. 
Una vez obtenido el mutante en el gen blr3699, denominado flg $D_{3}:: \mathrm{Km}$, realizamos ensayos de movilidad y extracción de flagelinas extracelulares. Pudimos observar que esta mutación no impide la síntesis de las flagelinas subpolares ni tampoco las laterales, y la performance de natación es similar a la de la cepa WT (Figura III.10).

A

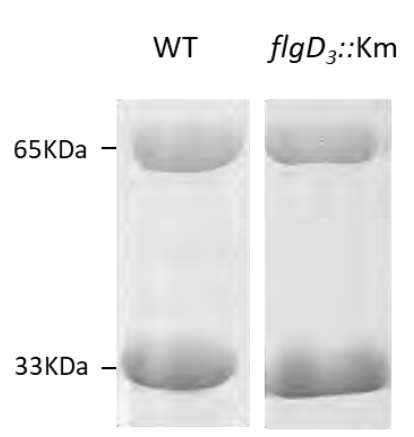

B

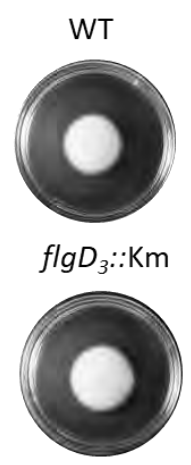

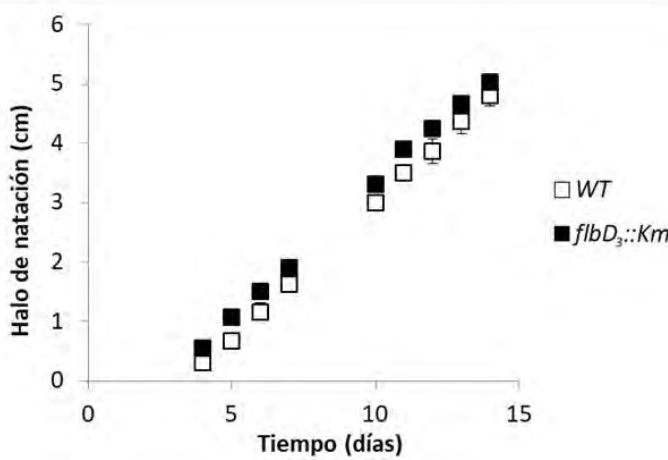

Figura III.10 - Perfil de flagelinas (A) y ensayos de movilidad en agar semisólido (B) de las cepas de $B$. diazoefficiens mutantes en flg $D_{3}$. A. SDS-PAGE de flagelinas extracelulares de cepa WT y $f \lg _{3}:: \mathrm{Km}$. B. Ensayo de natación en agar semisólido. Se muestran fotos representativas de cada cepa en placas de Petri a los 10 días. Los halos de natación de tres réplicas técnicas fueron registrados en función de los días y graficados con el desvío estándar.

\section{III.5 Conclusión y perspectivas}

En el genoma de $B$. diazoefficiens USDA 110 encontramos dos copias de genes del motor y de los genes que conforman el gancho que podrían ser componentes del flagelo subpolar de esta bacteria.

En algunas bacterias se observó que las proteínas MotAB/PomAB son capaces de incorporarse y liberarse de la estructura una vez formado el flagelo (Toutain et al., 2005; Paulick et al., 2009; Wilhelms et al., 2009). Según datos bibliográficos, distintas proteínas Mot, codificadas por genes diferentes, pueden participar de la formación de un mismo motor y de esta manera lograr aumentar o disminuir el torque de la estructura en función de determinados estímulos (Backer y O'Toole, 2017). Incluso en algunos casos, se ha reportado un intercambio de proteínas PomAB por MotAB de acuerdo a la concentración de $\mathrm{Na}^{+}$en el ambiente (Paulick et al., 2009); y en otros, se observó un intercambio de proteínas MotAB que permite generar una disminución de la velocidad de rotación (que normalmente son requeridos para otros procesos como nearsurface swimming o formación de biofilms) (Backer y O'Toole, 2017).

La mutación de $\operatorname{mot}_{1}$ no generó una deficiencia en la capacidad de natación con respecto a la cepa WT. Por el contrario, parecería que la capacidad de natación de las cepas que no poseen $\operatorname{mot}_{1}\left(\Delta \operatorname{mot} B_{1}\right.$ y $\left.\Delta \operatorname{mot} B_{1}-\Delta f l i C\right)$ fue ligeramente mayor a sus respectivas cepas parentales. Parecería entonces que MotB $_{1}$ podría estar actuando sobre el sistema de flagelos laterales ralentizándolos de manera similar a lo que 
mencionamos anteriormente. Quizás MotB $_{1}$ también sea capaz de actuar sobre el sistema subpolar. Para comprobar esto sería necesario obtener la cepa que carece de flagelinas laterales y de $\operatorname{mot}_{1}$ y evaluar su capacidad de nado.

Simultáneamente, la Dra. Julia Althabegoiti (integrante de nuestro grupo de trabajo) realizó una mutación mediante inserción de un cassette de $\mathrm{Km}$ en el gen blr3800 que codifica PomB, seguida de una deleción de las flagelinas laterales (cepa denominada pomB::Km- $\Delta / a f A)$. Este mutante fue incapaz de generar un halo de natación en agar semisólido. De esta manera, parecería que PomAB, a diferencia de Mot $A B_{1}$, es indispensable para la formación de un motor funcional del flagelo subpolar en B. diazoefficiens. A pesar de ello, Kanbe y col. (2007) describieron que los dos sistemas flagelares de $B$. diazoefficiens utilizan $\mathrm{H}^{+}$y no $\mathrm{Na}^{+}$, de manera que la nomenclatura utilizada para nombrar estas proteínas parecería no correlacionarse con su función.

Los genes del gancho que se encuentran en el cluster $3\left(f l g D E K L_{3}\right)$, parecerían no ser necesarios para la formación del flagelo. A diferencia de lo que ocurre con las proteínas Mot (las cuales se ensamblan de manera dinámica en la membrana bacteriana), las proteínas del gancho son ensambladas y no se intercambian una vez polimerizadas (Imada, 2017). Al ser proteínas estructurales importantes para la formación del filamento del flagelo, esperábamos observar un efecto marcado sobre la performance de natación en el mutante simple $f\left(g D_{3}:: K m\right.$ (similar al que observamos en el mutante $\Delta f(i C)$ si efectivamente forman parte de la estructura del flagelo subpolar. Dado que el mutante en este gen no sufrió ningún impedimento en su capacidad de natación y sumado a la baja señal de lecturas en ensayos de RNAseq de estos genes, los genes del gancho ubicados en el cluster 3 no serían funcionales en este microorganismo. En ese caso, queda la incógnita acerca de si lo mismo sucede con otros genes que se encuentran en dicho cluster pero no los hemos encontrado en otra región del genoma, como es el caso de los genes que codifican FliS y FliD, ambas proteínas necesarias para formar el filamento del flagelo. A su vez, se observa una flagelina FlaA adyacente que no ha sido detectada como parte del flagelo subpolar (Quelas et al., 2016a). No sabemos aún si los genes de este cluster se expresan en otras condiciones ambientales o si verdaderamente representan pseudogenes.

Por otro lado, encontramos cinco genes reguladores distribuidos en tres clusters diferentes, similares a los reguladores de las distintas etapas de síntesis del flagelo polar que han descriptos en $C$. crescentus. Dentro de ellos encontramos a CtrA, el cual fue descripto como regulador maestro responsable de iniciar la cascada regulatoria. Adicionalmente identificamos a FlbD y FliX, también denominados reguladores de clase II, encargados de coordinar la etapa siguiente de la síntesis y el par FlaF/FlbT como reguladores de clase III. Esta identificación, sumada a la falta de otras proteínas presentes en otros modelos regulatorios como por ejemplo FlhD o FleQ/FIrA (reguladores maestros), nos permiten plantear la hipótesis de que la síntesis del flagelo subpolar de $B$. diazoefficiens está regulado a través de estas cinco proteínas. 


\section{III.6 Anexo}

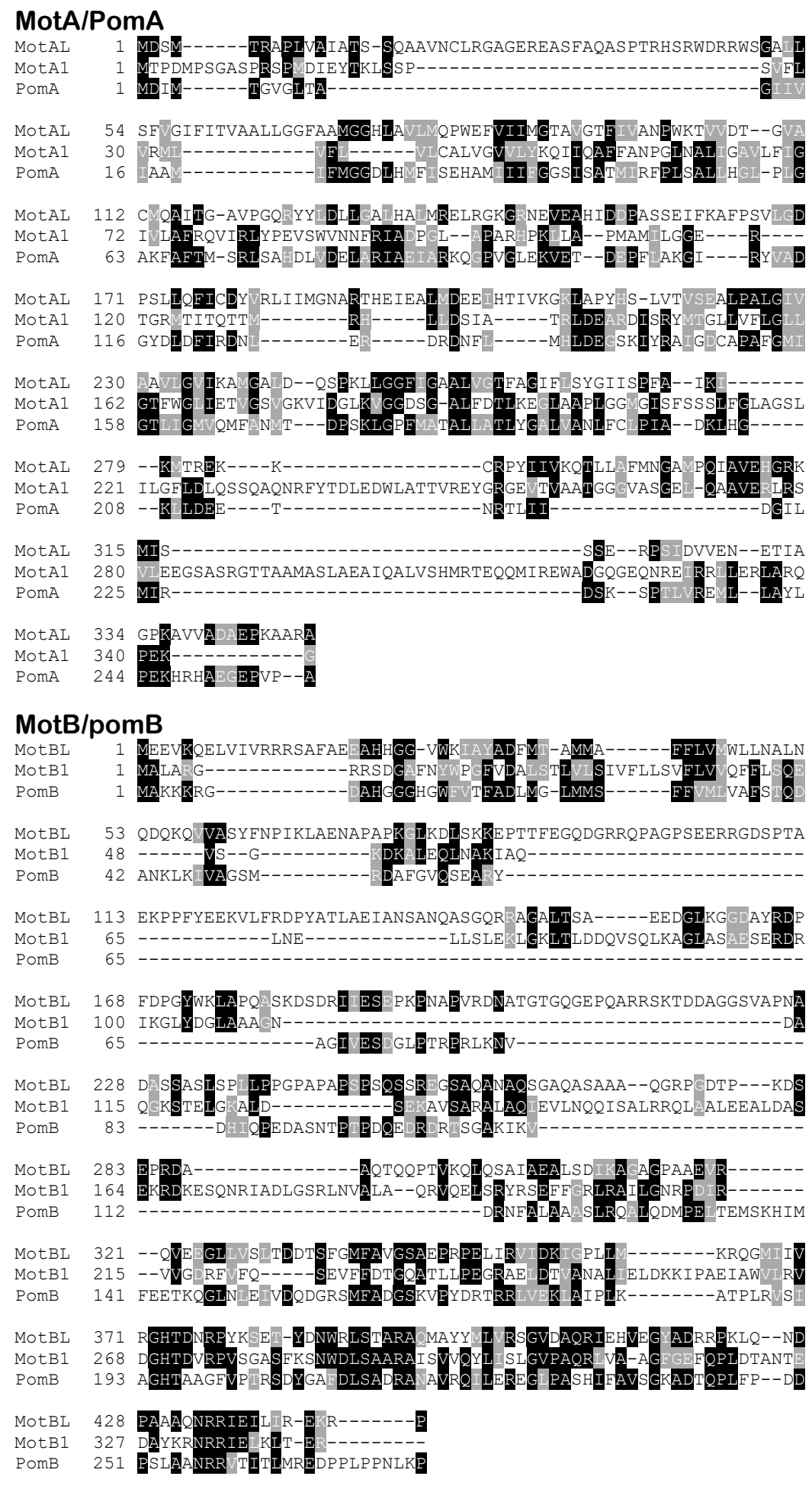

Figura Alll.1 - Alineamiento múltiple de proteínas parálogas del motor:

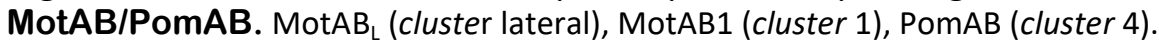


FlgD

FlgDL

FlgD3

1 MVTSATDSTSKSSSSTSSTTSTSSNSVDYNTELQLLVAEMKNQDPTNPMDTSQYMSQFA

FlgD6

1 MTINS-

FlgDL

61 QLSTVEQA

FlgD3

6 -

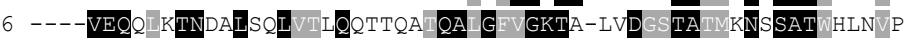

FlgD

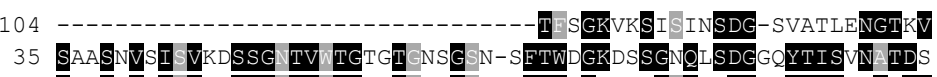

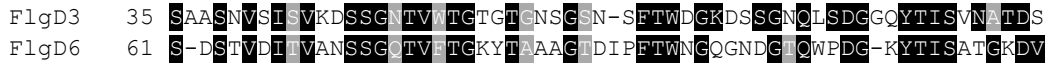

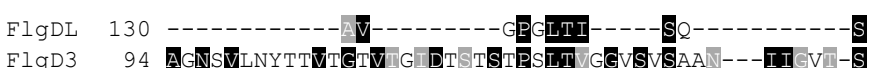

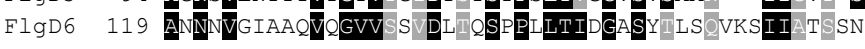

FlgE

FlgEL

FlgE3

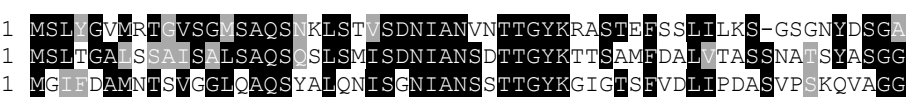

FlgEL

FlgE3

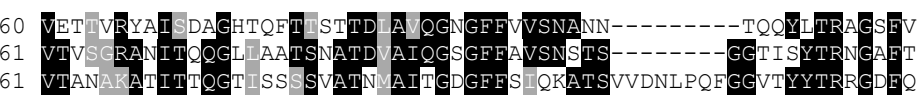

FlgEI

1 PDA GNLVN AGYY GQPG------------KVTNGSONS

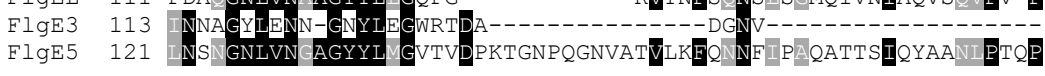

FlgE

Flge 3

FlgE5

STA

\section{- GNIDO}

NTA STIAASKTLLAAGGINBSDFQANPLPVGTPPAPYTSATVSGAAATGNIRSAYSSTT

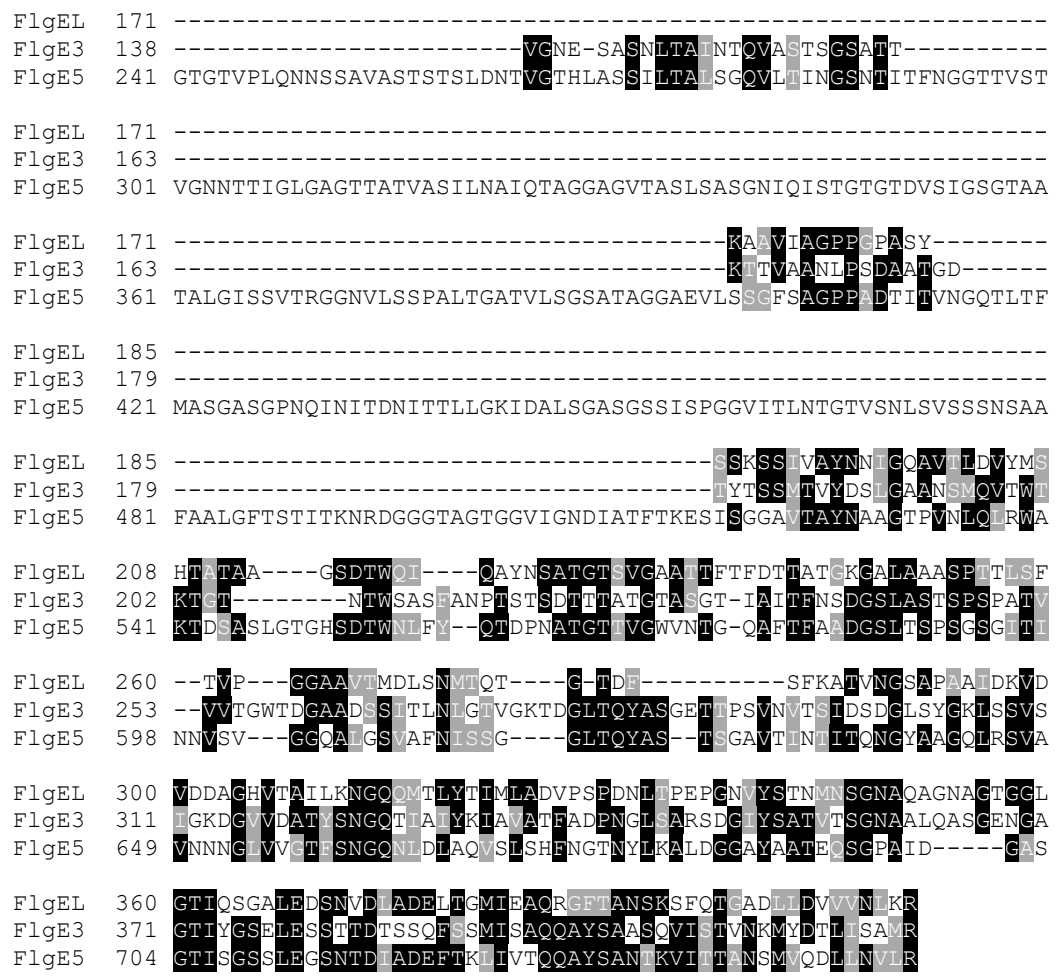

FlgK

FlgKL

FlgK 3

FlgK5

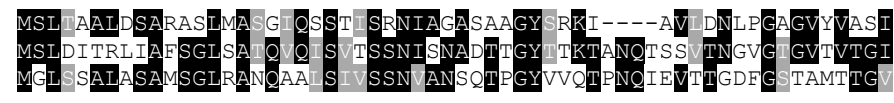

FlgKL

(1)

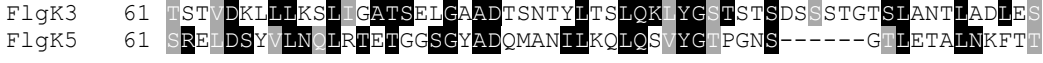

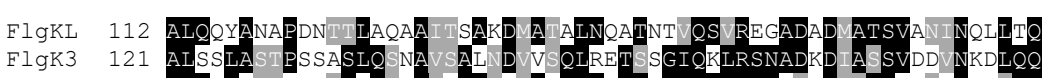

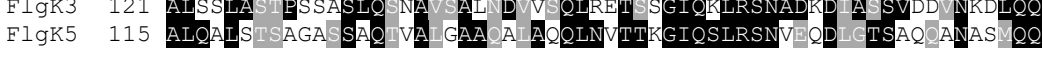

$\begin{array}{llll}\text { FlgKL } & 172 & \text { FDKVNNAVVRGTIAGDDVTDY DQRD IV SKLSQEVGVSMS IRANGDAA YTD SGVVLED } \\ \text { FlgK3 } & 181 \text { IANVNAEIKQVAASGESTADLEDQRN A DVASKMNVSYETASNGDLQVTTSGQALD }\end{array}$ 


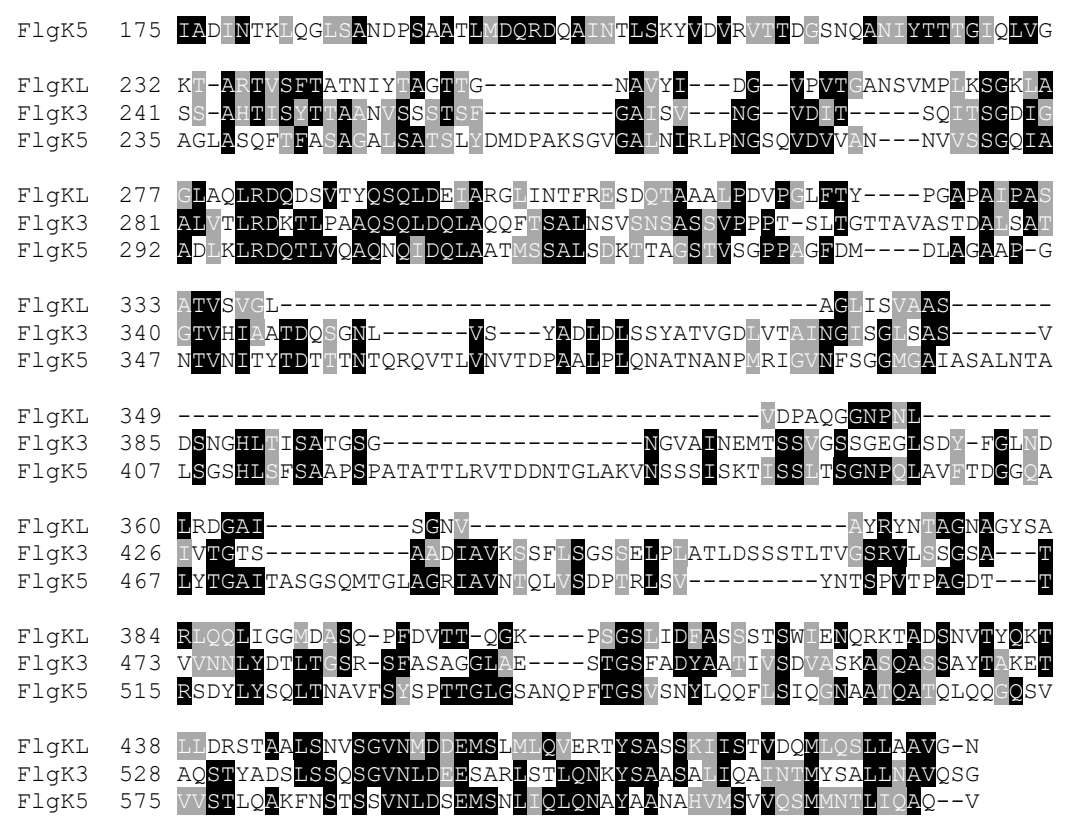

FlgL

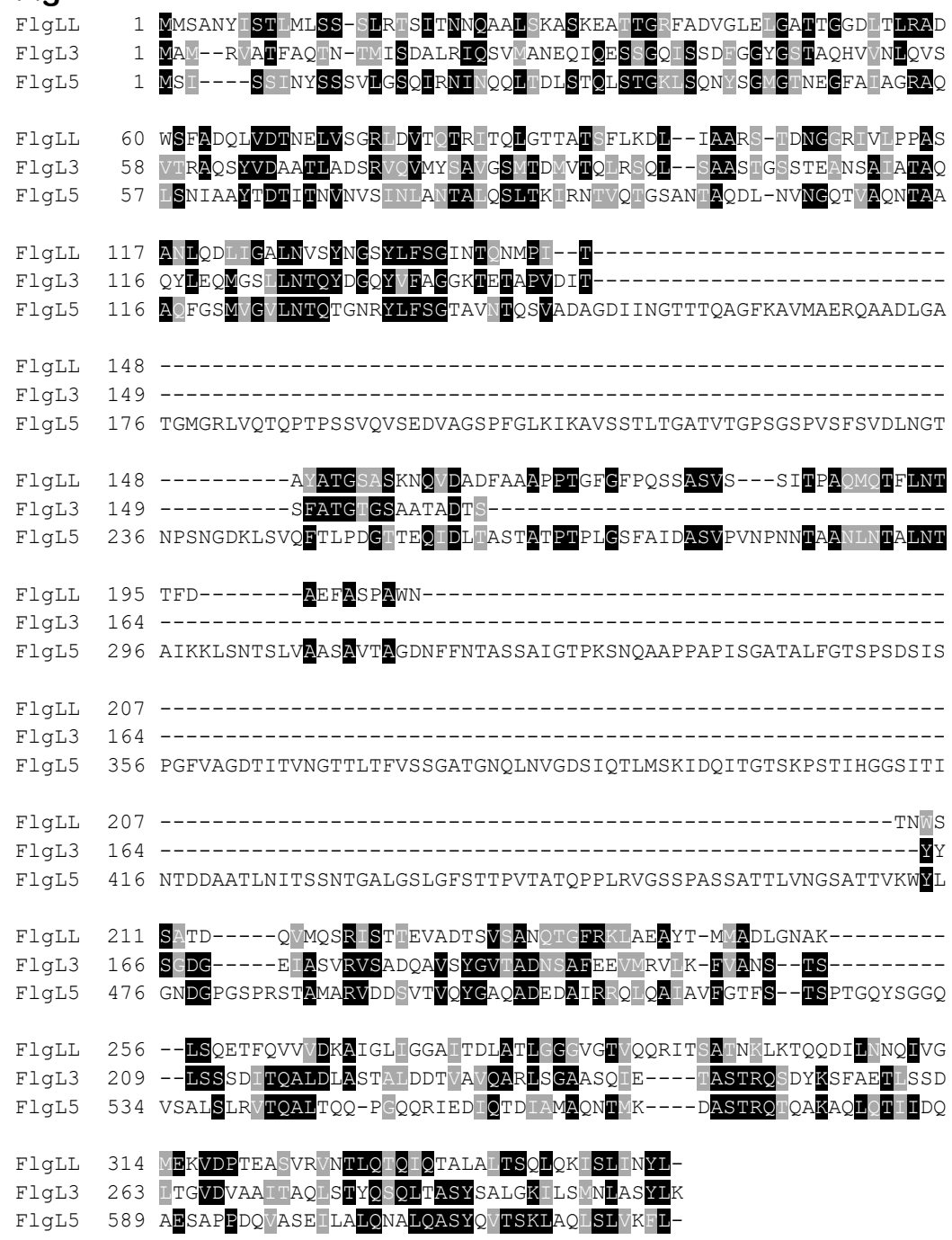

Figura AllI.2 - Alineamientos múltiple de proteínas parálogas del gancho: FlgDEKL. FlgDEKL (cluster lateral), FlgDEKL3 (cluster 3), FlgD6 (cluster 6), FlgEKL5 (cluster 6). 


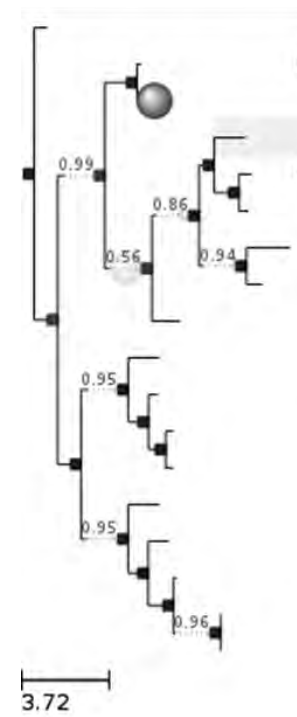

Desulfovibrio vulgaris Rhodopseudomonas palustris Bradyrhizobium japonicum Rhodospirillum rubrum

Rhodopseudomonas palustris Bradyrhizobium japonicum

Rhodobacter sphaeroides

Caulobacter crescentus

Rhodospirillum rubrum

Shewanella oneidensis

Pseudomonas aeruginosa

Pseudomonas syringae

Pseudomonas putida

Rhodobacter sphaeroides

Nitrosomonas europaea

Escherichia coli

Salmonella choleraesuis

Salmonella enterica

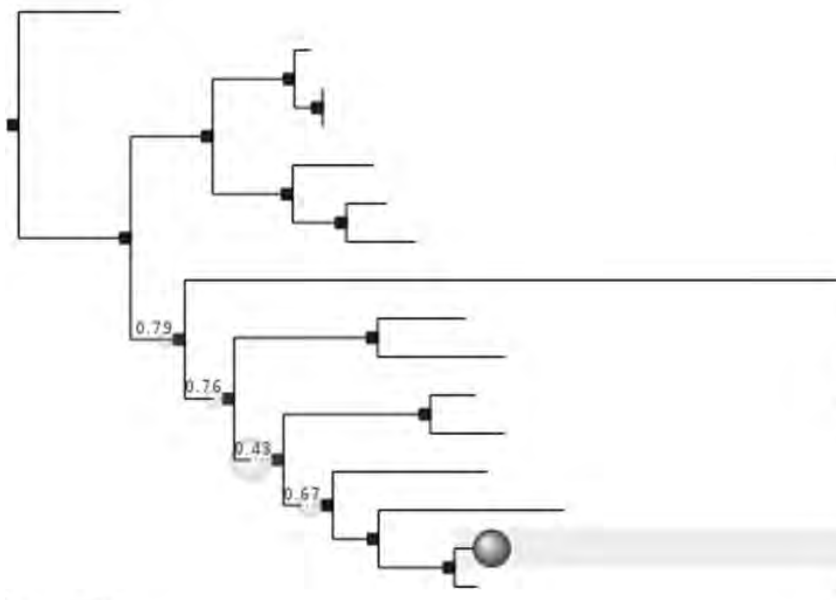

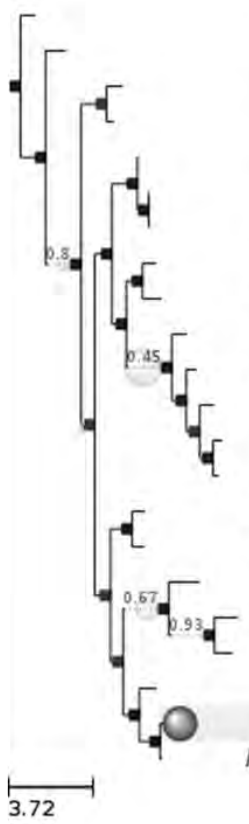

Listeria monocytogenes Helicobacter pylori Desulfovibrio vulgaris Desulfovibrio vulgaris Escherichia coli

Salmonella enterica

Salmonella choleraesuis Shewanella oneidensis

Rhodobacter sphaeroides

Nitrosomonas europaea

Pseudomonas aeruginosa

Pseudomonas syringae

Pseudomonas syringae

Pseudomonas putida

Bradyshizobium japonicum

Agrobacterium tumefaciens

Rhodospirillum rubrum

Rhodobacter sphaeroides

Caulobacter crescentus

Rhodospirillum rubrum

Bradyrhizobium japonicum

Rhodopseudomonas palustris

FlgE3

FlgEL
Desulfovibrio vulgaris

Escherichia coli

Salmonella enterica

Salmonella choleraesuis

Pseudomonas aeruginosa

Pseudomonas putida

Pseudomonas syringae

Bradyrhizobium japonicum Bradyrhizobium japonicum

Agrobacterium tumefaciens

Rhodopseudomonas palustris Bradyrhizobium japonicum

Rhodospirillum rubrum

Caulobacter crescentus

Bradyrhizobium japonicum

Rhodopseudomonas palustris
FlgKL

FlgK5

FlgK3

0.71

Clostridium difficile

Oceanobacillus iheyensis

Bacillus subtilis

Escherichia coli

Caulobacter crescentus

Rhodospirillum rubrum

Bradyrhizobium japonicum

Rhodopseudomonas palustris

3.72
FlgL3

Figura Alll.3 - Árboles filogenéticos extraídos de PhylomeDB de proteínas del gancho del cluster 3 (FlgDEKL3). 
Capítulo IV: CtrA y su función como regulador del flagelo subpolar de $B$. diazoefficiens USDA 110 



\section{IV.1 Introducción}

Las $\alpha$-proteobacterias son un grupo extenso y diverso de bacterias con diferentes estilos de vida, desde patógenos intracelulares obligados o facultativos, simbiontes de plantas o animales hasta organismos de vida libre. A pesar de esta gran diversidad, muchos procesos como la replicación del ADN, metilación, división celular y movilidad son coordinadas por proteínas y redes de señalización que se encuentran muy conservadas en todas ellas (Francez-Charlot et al., 2015). Un ejemplo de ello es lo que ocurre con la proteína CtrA, la cual se encuentra involucrada en procesos fundamentales para la bacteria como son la progresión de ciclo celular y organogénesis de estructuras polares (Laub et al., 2002).

CtrA es un regulador de respuesta de sistema de dos componentes que controla diferentes etapas del ciclo celular, activando o reprimiendo promotores, modificando el desarrollo del polo bacteriano y regulando la expresión de genes flagelares (Quon et al., 1998; Laub et al., 2002; Brilli et al., 2010). En su estado fosforilado, (CtrA P) activa la transcripción de determinados genes y a su vez impide la división celular mediante la unión al origen de replicación del cromosoma (Quon et al., 1998). Es por esta razón que la actividad de esta proteína se encuentra regulada por numerosas proteínas durante la progresión del ciclo celular. Así, la función global de CtrA en la célula resulta de la convergencia de varias vías de señalización (Brilli et al., 2010).

El complejo mecanismo de regulación de esta proteína ha sido estudiado con gran detalle en $C$. crescentus, una de las bacterias modelo más utilizadas para su caracterización dada su particular división celular asimétrica (Davis y Viollier 2001; Laub et al., 2002; Reisenger et al., 2007; Angelastro et al., 2010). En dicha especie, cada ciclo de división celular concluye con dos células hijas que son morfológica y funcionalmente diferentes: una célula inmóvil denominada stalked y una móvil, llamada swarmer. La célula stalked permanece fija a una superficie y tiene la capacidad de iniciar un nuevo ciclo de división celular, mientras que la célula swarmer que posee pili y flagelo, es capaz de moverse y colonizar un nuevo nicho. Esta célula swarmer puede finalmente diferenciarse a una nueva célula stalked y continuar el ciclo (Laub et al., 2007). Recientemente, se ha visto que esta división asimétrica también ocurre en otras $\alpha$-proteobacterias, y algunas de las vías regulatorias que determinan el momento del ciclo celular y la localización específica donde ocurre cada proceso celular, también se mantienen conservadas. (Hallez et al., 2004). A continuación, describiremos brevemente la regulación de CtrA basándonos principalmente en el modelo más estudiado descripto para C. crescentus. 


\section{Cascada de señalización de CtrA}

CtrA se encuentra regulada transcripcionalmente a través de las proteínas DnaA y GcrA, ambas involucradas en el proceso de división celular, y reprimida por la acción de la metiltransferasa CcrM (Brilli et al., 2010; Panis et al., 2015). Una vez traducida, CtrA es fosforilada mediante un sistema de phophorelay o transferencia de fosfato, en el que participan varias proteínas. Este sistema comienza con la autofosforilación de CckA (la cual posee actividad quinasa y fosfatasa) que puede pasar el fosfato a ChpT, una proteína transferidora de fosfato hacia CtrA. Además, este fosfato puede ser transferido de manera inversa promoviendo la desfosforilación de CtrA P. Asimismo, la fosforilación de CckA está regulada negativamente por DivK-P, un regulador de respuesta del sistema de dos componentes, DivJ-Divk. Su fosforilación, no solo depende de su par histidina quinasa DivJ sino también de la fosfatasa PleC. (Figura IV.1) Otra proteína, denominada DivL, también interfiere en este proceso de señalización. Si bien su función no está completamente determinada, recientemente se probó que DivL interacciona con CckA a través de sus dominios PAS (sensores de señales). Así, la unión entre ambas proteínas favorece la actividad quinasa de CckA. Sin embargo, cuando DivL interacciona al mismo tiempo con DivK-P, CckA actuaría como fosfatasa (Mann y Shapiro, 2018).

Adicionalmente a la regulación por fosforilación, la actividad de CtrA es controlada mediante degradación proteica. La misma ocurre por efecto de la proteasa ClpXP, la cual es activada por CpdR. A su vez, CckA es capaz de inhibir la acción de CpdR mediante fosforilación, activando CtrA a través de la vía de transferencia de fosfato e inhibiendo la vía de degradación proteica (Angelastro et al., 2010).

Por último, la vía cuenta con reguladores negativos, llamados SciP y MucR, los cuales son capaces de reprimir la transcripción de algunos de los genes diana de CtrA en distintas fases del ciclo celular sin modificar la unión de CtrA P al origen de replicación. Durante la fase G1 SciP impide la unión de la ARN polimerasa a los promotores de los genes regulados por CtrA en fase $\mathrm{G} 2$, mientras que durante la fase G2, MucR se une a los promotores de los genes regulados por CtrA en G1 impidiendo la unión de esta proteína a los mismos (Panis et al., 2015).

La correcta localización subcelular de todos los reguladores que participan en la fosforilación de CtrA también posee un rol fundamental. Esta distribución diferencial asegura una distribución heterogénea de CtrA y CtrA P de modo de lograr controlar la morfogénesis polar de ciertas estructuras y la división celular al mismo tiempo. De esta manera, como se observa luego de la división celular en $C$. crecentus, se generan dos células fenotípicamente diferentes: una célula móvil flagelada y otra inmóvil, adherida a una superficie (Schallies et al., 2015). 


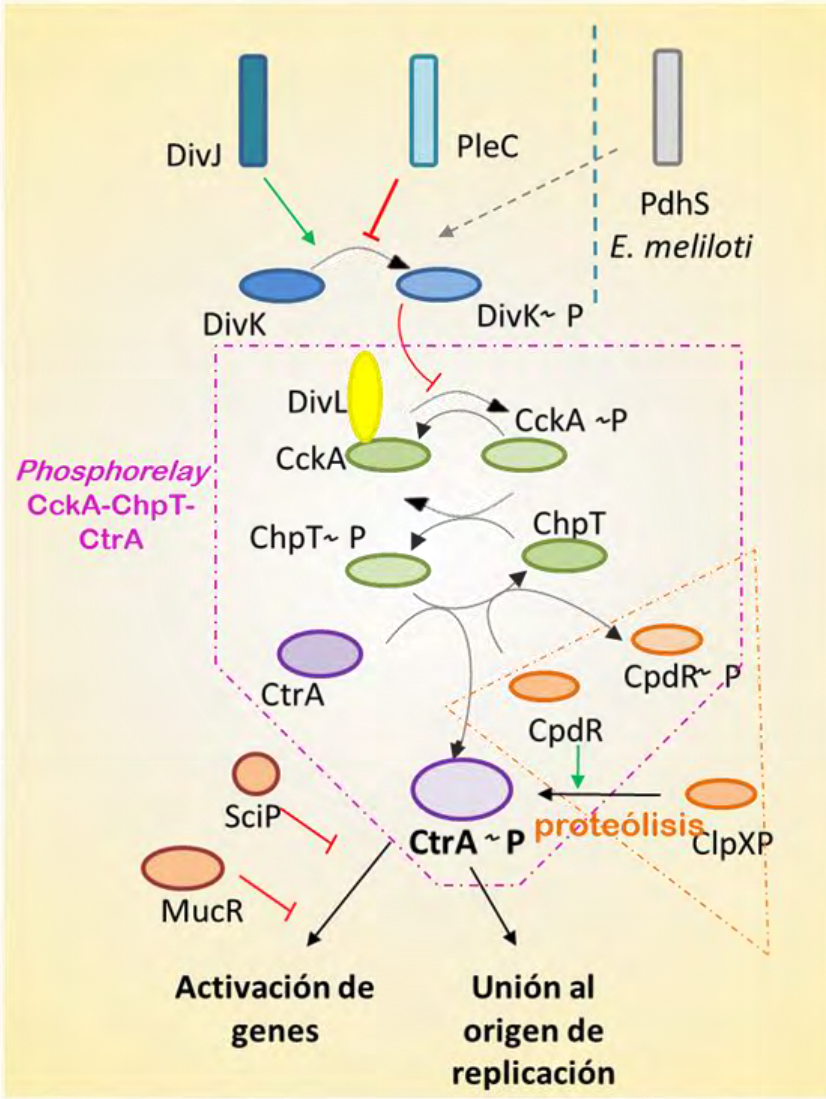

Figura IV.1 - Cascada regulatoria de la proteína CtrA. El gráfico muestra la cascada de señalización de CtrA en base al modelo descripto en $C$. crescentus. En violeta se encuentra recuadrado el sistema de phosphorelay CckA-ChpT-CtrA y en naranja la vía de degradación proteica. También se muestra la regulación de CckA mediante Divk, y la existencia de otras proteínas denominadas PdhS que están involucradas en este proceso y han sido descriptas en E. meliloti. Finalmente, Scip y MucR interfieren en la activación transcripcional de ciertos genes diana de CtrA.

\section{CtrA y la conexión con el ciclo celular en $\alpha$-proteobacterias}

Dada esta íntima relación de CtrA con el ciclo celular, el estudio de esta proteína mediante deleción del gen que la codifica no ha sido posible en algunas $\alpha$ proteobacterias de los ordenes Caulobacterales y Rhizobiales, aunque sí ha sido posible en algunos Rhodobacterales y Sphingomonadales (Quon et al., 1998; Barnett et al., 2001; Mercer et al., 2010; Francez-Charlot et al., 2015). La incapacidad de generar mutantes en ctrA indicaría que en algunas $\alpha$-proteobacterias el rol de CtrA sobre el ciclo celular es distinto. Además, se ha detectado que las proteínas que activan CtrA mediante fosforilación, no poseen conservados sus dominios sensores, lo que indicaría que la activación de CtrA a través de esta vía estaría promovida por distintas señales en cada bacteria. Incluso en Rhizobiales, se han encontrado otros genes homólogos a pleC y divJ, denominados pdhS que también están involucrados en la señalización por fosforilación de CtrA (Hallez et al., 2004). 


\section{IV.2 Análisis bioinformático de los componentes que integran la cascada de señalización de CtrA en B. diazoefficiens}

Como mencionamos en el Capítulo III, utilizamos herramientas bioinformáticas para la asignación de función del gen a estudiar. En este caso, identificamos a bll2200 como posible gen codificante de CtrA en B. diazoefficiens USDA 110.

La proteína Bll2200 codificaría un regulador de respuesta de sistema de dos componentes típico, conformado por un dominio REC en el extremo amino terminal con su sitio de fosforilación conservado (D51) y un dominio de unión a ADN en el extremo carboxilo terminal. Bll2200 de B. diazoefficiens presenta un $83 \%$ de similitud con la proteína CtrA caracterizada en $C$. crescentus (Figura IV.2). Si bien CtrA está presente en todas la $\alpha$-proteobacterias, y su principal función se encuentra asociada con el control del ciclo celular, en algunos casos esta proteína se ha especializado y limitado a una vía de señalización en particular (Brilli et al., 2010).

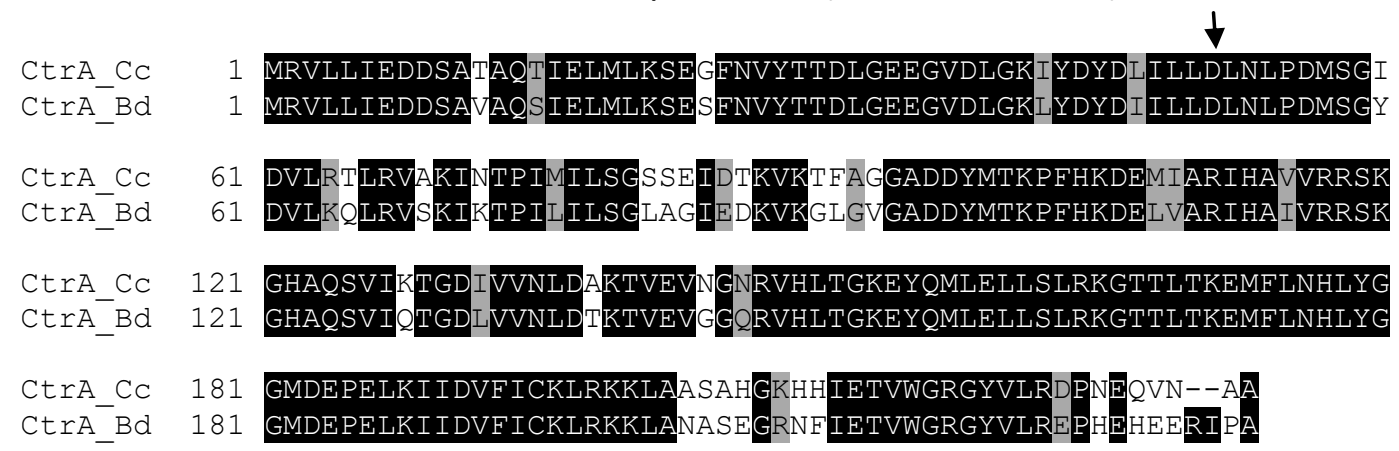

Figura IV.2 - Alineamiento de CtrA de C. crescentus y B. diazoefficiens .Las mismas fueron simbolizadas con las letras $C$ c para $C$. Crescentus y $B d$ para $B$. diazoefficiens. Con una flecha se indica el aminoácido conservado D51 sujeto a fosforilación (Quon et al., 1996).

Mercer y colaboradores caracterizaron la función de CtrA en Rhodobacter capsulatus y realizaron una correlación filogenética entre la función del gen y la familia a la que pertenece. A fin de extender este análisis a $B$. diazoefficiens e incluir otras especies donde se ha determinado experimentalmente su función, se construyó el árbol filogenético que se muestra en la Figura IV.3. Así, pudimos determinar que CtrA de $B$. diazoefficiens agrupa junto con otros miembros del orden Rhizobiales como $E$. meliloti y en la rama más próxima con $C$. crescentus (Caulobacterales), en las cuales se demostró que CtrA constituye un gen esencial para la vida de la bacteria. Sin embargo, el grupo más cercano y que no se separa con un soporte alto, incluye a Sphingomonas y Erytrobacter (orden Sphingomonadales), bacterias en donde la mutación de ctrA es viable y donde CtrA solo controla la síntesis del flagelo (Francez-Charlot et al., 2015). 


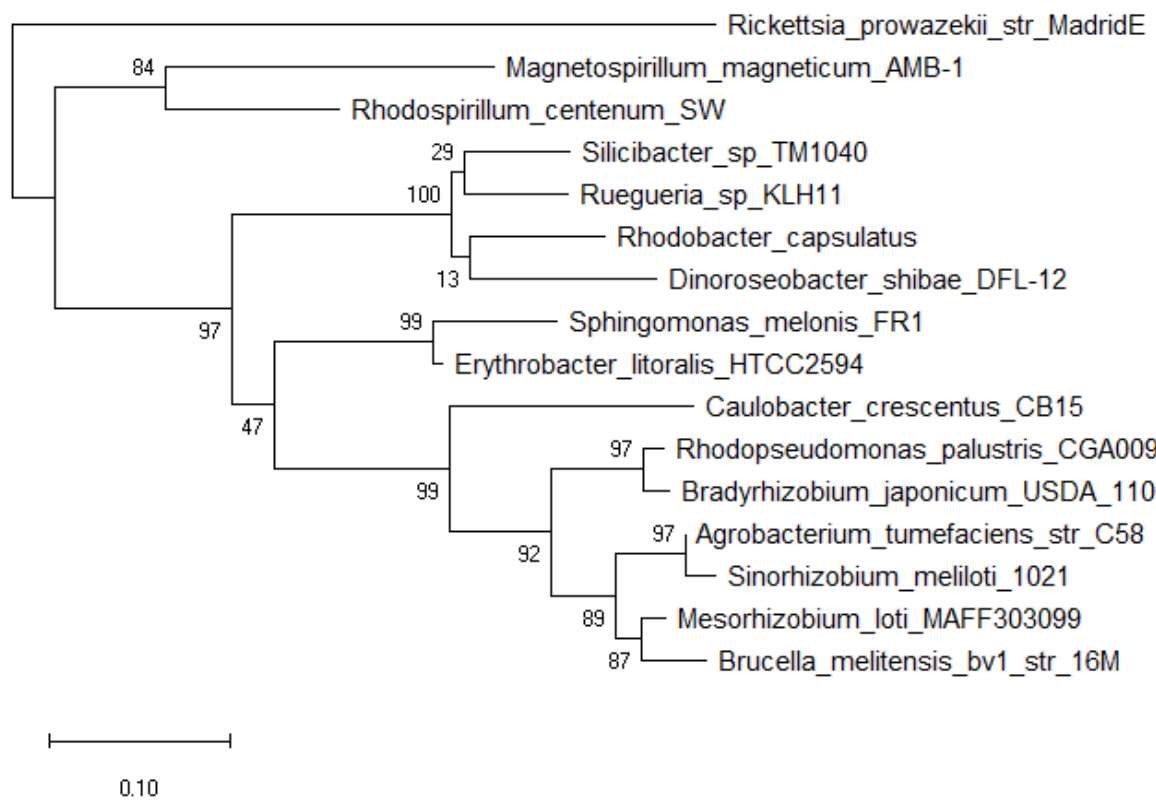

Figura IV.3 - Arbol filogenético construido con la proteína CtrA presente en Rhizobiales El árbol fue realizado utilizando el programa MEGA X (con el algoritmo de Maximun likelihood). El soporte de las ramas se calculó mediante el método de bootstrap con 1000 réplicas en el que se cargó la secuencia aminoacídica de las CtrA en distintas bacterias, con énfasis en Rhizobiales y en bacterias donde CtrA tiene función conocida.

Con el fin de profundizar en la vía de señalización que involucra a CtrA, se buscaron los demás posibles participantes de la misma. La búsqueda se realizó en base a las proteínas caracterizadas en $C$. crescentus. En la Tabla IV.1 se muestran los locus tag que codifican cada una de las proteínas identificadas y el porcentaje de identidad aminoacídica comparado con su homólogo.

De acuerdo a estos resultados, $B$. diazoefficiens presentó homólogos para todos los integrantes de la vía de señalización, tanto en la vía de fosforilación (CckA-ChpT) como las proteínas que actúan a un nivel superior (PleC-DivJ-DivK). Al igual que se observa en otros microorganismos, se detectó una mayor variabilidad en las regiones $\mathrm{N}$-terminales de las proteínas relacionadas a la percepción de la señal (dominios sensores PAS/PAC), aunque en general, la organización de dominios entre homólogos parece respetarse. En el caso particular de la quinasa/fosfatasa CckA se vio una diferencia clara en la organización de dominios en el extremo amino terminal, al igual que en PleC y DivJ, pero en menor grado (Ver Anexo Figura AIV.1). Esto estaría relacionado a que diferentes señales podrían ser las involucradas en la activación y/o control de la vía.

Con respecto al control de CtrA mediante proteólisis, también hemos encontrado todas las proteínas con un alto porcentaje de similitud e identificamos dos proteínas homólogas a las proteasas de la familia ClpP, donde la más conservada se encuentra contigua a ClpX.

Además, encontramos una proteína similar a SciP y una sola proteína similar a MucR con un mayor porcentaje de similitud con la proteína MucR2 de C. crescentus. 
Tabla IV.1 - Predicción de dominios de las proteínas involucradas en la vía de señalización de CtrA en B. diazoefficiens y C. crescentus.

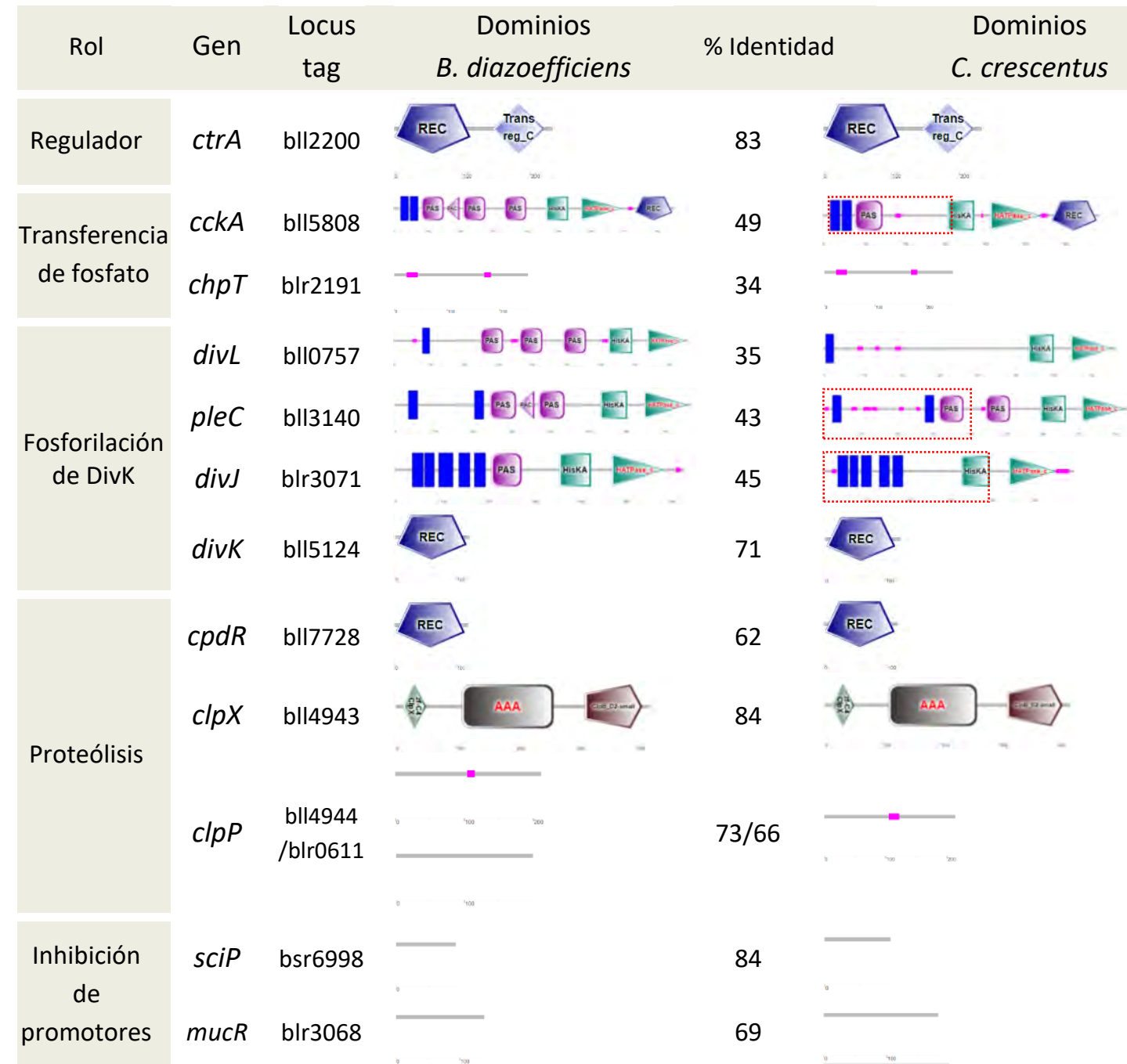

La Tabla muestra los locus tag de los genes que estarían involucrados en la vía de señalización de CtrA en $B$. diazoefficiens y la predicción de dominios de las proteínas identificadas en comparación con las proteínas caracterizadas en $C$. crescentus. Se utilizaron los servidores SMART y BLASTp.

A continuación, se muestran los dominios detectados en las proteínas con mayor tamaño:

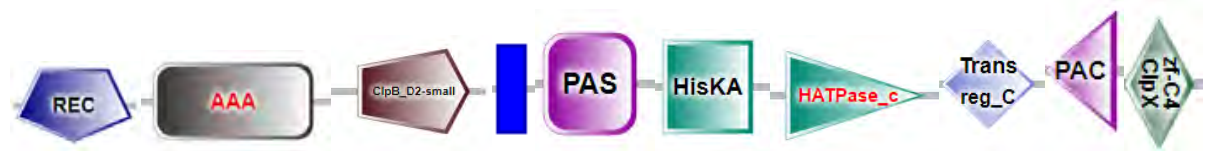

El polígono azul representa dominios REC (PF00072), los rombos verdes representan el dominio zfC4_ClpX (PF06689, el rectángulo negro representa el dominio AAA+(PF07724), el polígono marrón representa el dominio ClpB_D2-small (PF10431), el rectángulo azul representa dominios transmembrana, el cuadrado violeta representa dominios PAS (PF00989), el cuadrado verde representa dominios HisKA (PF00512), el triángulo verde representa dominios HATPasa_C (PF02518), con rombo azul se muestra el dominio Trans reg_c (PF00486) y con un triángulo violeta se marcan los dominios PAC (SM00086)

A diferencia de lo que ocurre en $C$. crescentus, B. diazoefficiens presenta otras proteínas histidina quinasas híbridas homólogas a PleC, que en algunos 
microorganismos se denominaron PhdS, y que podrían estar involucradas en la activación de CtrA a través de la modificación del estado de fosforilación de Divk. Ello representa otro indicio de que la misma vía estaría siendo alimentada por señales diferentes en estas $\alpha$-proteobacterias.

Con respecto a los genes regulados por CtrA, en distintas bacterias se encuentran algunos que se han conservado a lo largo de la evolución y otros que han ido cambiando. Un ejemplo de esto se ve reflejado en la relación de CtrA con la síntesis del flagelo, el cual parece estar bajo su control solo en algunos microorganismos. En $E$. meliloti, CtrA se encuentra íntimamente relacionado con los procesos de división celular, aunque no actúa como regulador maestro de sus flagelos. Sin embargo, en $C$. crescentus, esta proteína está involucrada en ambos procesos y también en otros relacionados con la diferenciación polar (Laub et al., 2002). En el otro extremo encontramos a Rhodobacter sphaeroides, en donde solo interviene en la regulación de la síntesis flagelar, siendo un gen no esencial para la vida de la bacteria (Mercer et al., 2010).

Sintetizando los resultados de estos análisis bioinformáticos, hemos encontrado toda la vía completa de activación de CtrA en B. diazoefficiens USDA 110, al igual que en otros Rhizobiales (Brilli et al., 2010). Creemos que esta proteína podría controlar el ciclo celular en este microorganismo y su deleción sería inviable. Aun así, la presencia de la rama cercana al agrupamiento que incluye a $B$. diazoefficiens junto con los Sphingomonadales en el árbol filogenético deja una pequeña incógnita respecto de esta última hipótesis.

\section{CtrA como regulador maestro del flagelo subpolar}

CtrA cumple un rol fundamental en la síntesis del flagelo polar en C. crescentus (Smith y Hoover, 2009; Ardissone y Viollier, 2015). En esta bacteria, CtrA (regulador de clase I) es el regulador maestro de esta cascada de señalización, e inicia la síntesis de la estructura. CtrA P se une a promotores generalmente con la secuencia consenso TTAA-N7-TTAAC o TTAACCAT y junto con la holoenzima $\sigma^{73}$ de la ARN polimerasa, comienza la transcripción de los genes tempranos de la síntesis del flagelo denominados genes de clase II. Dentro de estos genes se encuentran aquellos que codifican las proteínas que forman parte del cuerpo basal del flagelo (anillos, SSTIII, proteínas estructurales y del switch del motor) y también otros genes reguladores como flbD, fliX (ambos reguladores de clase II) y rpoN (factor $\sigma^{54}$ de la ARN polimerasa) (Laub et al., 2002). Estos serán los encargados de desencadenar la siguiente etapa de la síntesis flagelar, la cual será detallada en el Capítulo V.

Como primera aproximación, realizamos una búsqueda de las secuencias promotoras reconocidas por CtrA descriptas previamente sobre el genoma completo de $B$. diazoefficiens utilizando el servidor MEME suite (algoritmo MAST). En esta base de datos solo se encuentra cargado el genoma de B. japonicum USDA 6, por lo que nuestra búsqueda se limitó a esta bacteria. Posteriormente, identificamos los genes en 
B. diazoefficiens USDA 110 utilizando BlastP (Anexo Tabla AIV.1). A través de este análisis encontramos secuencias de reconocimiento de CtrA en promotores de genes relacionados con la síntesis del flagelo subpolar. En la Figura IV.4 mostramos un alineamiento de las cajas putativas conservadas que fueron identificadas sobre promotores de genes del flagelo subpolar en B. diazoefficiens USDA 110.

Gen locus tag
CtrA bll2200
fliL bll5826
fliCl bll5843
fliX bll5837
fliF blr6999
flgB bll5814
fliC2 bll5844
flil blr2201
flaF bll5842
fliC3 bll5845
flhA bll2207
flbT blr5847
fliC4 bll5846

\begin{tabular}{|c|c|c|}
\hline TCAGGATTTGTTAACCATCTGTTG-TCAG & (89) ATG & \\
\hline -AAAGGTTCCGTTAACCATTATTACCGTA- ( & & \\
\hline - TAAACCGGCGTTAACCATACTTTAAAGG- & ( 80$)$ ATG & \\
\hline TTACGCGCCGTTAACCATAAAACAGCGA- & (31) ATG & \\
\hline -TTAATCTTCGTTAACCATATCGAAACCA- & (65) ATG & \\
\hline -TGTGACATCCTTAACCACCTGTTAACCA- & (65) ATG & \\
\hline -TCACCCTTTGTTAGCCATGTCGCG-GCAC & (64) ATG & \\
\hline -GACGCAATGATTAACGATGCGGGT-AAAC ( & (127) ATG & \\
\hline AGCAAATCTTAAGCGGTGCTGCCTAG- & (60) ATG & \\
\hline TCATGCTTTGTTAGCCCTGGACGT-TCAC & (65) ATG & \\
\hline CCCCCTCGTTAACCCTTTGCTAACCA- & (65) ATG & \\
\hline -TTACAGCTCGTTAACTAATTCCGAGCGA- & (62) ATG & \\
\hline $\begin{array}{l}\text { AGTA-GCGTCGTTTACCAGAAGGGTAACA- } \\
\text { - }\end{array}$ & (5) ATG & \\
\hline
\end{tabular}

Figura IV.4 - Alineamiento de regiones promotoras de genes del flagelo subpolar en $B$. diazoefficiens USDA 110 que contienen la secuencia TTAACCAT. En gris se encuentran resaltadas las bases conservadas y los números entre paréntesis representan el número de bases hasta el codón de inicio de la traducción. A la derecha de cada secuencia se encuentra representada la estructura de la que forma parte la proteína que codifica ese gen, CB: cuerpo basal, SS: SSTIII, B: bastón, R: regulador, F: filamento.

La caja TTAACCAT se encontró conservada en algunos genes que forman parte de genes tempranos de la síntesis del flagelo subpolar que conforman el cuerpo basal del mismo, ubicados por delante del marco de lectura de los genes blr6999 y bll5826 (flif$G$, fliL-M). También se observaron estas secuencias de reconocimiento de CtrA cerca de genes regulatorios (algunas más conservadas que otras) por delante de los genes bll5837, bll5842 y blr5847 (flix, flaF y flbT) e incluso para el mismo ctrA (bll2200). Además, se encontraron cajas en genes que codificarían el SSTIII, blr2201 y bll2207 (flil, flhA) y el bastón proximal bll5814 (flgB-C fliE) los cuales necesitan del SSTIII para ser ensamblados. En las regiones promotoras que codifican las flagelinas subpolares (bll5843-46, flic1234) también se encontró la misma caja conservada.

Para comprobar el rol de CtrA como regulador maestro del flagelo subpolar de $B$. diazoefficiens nos propusimos una serie de estrategias que se detallan a continuación. En primer lugar, intentamos realizar una deleción de los genes ctrA y cckA. Como estrategia alternativa, en caso de que la mutación de estos genes no resultara viable debido al rol de estas proteínas dentro del ciclo celular, propusimos analizar el efecto sobre la síntesis flagelar mediante la sobreexpresión de CtrA. 


\section{IV.3 Obtención de una cepa mutante de $B$. diazoefficiens en ctrA}

Para abordar este estudio planteamos una estrategia de mutagénesis mediante doble recombinación homóloga, interrumpiendo el gen ctrA (bll2200) por inserción de un cassette de resistencia a antibiótico (Figura IV.5).

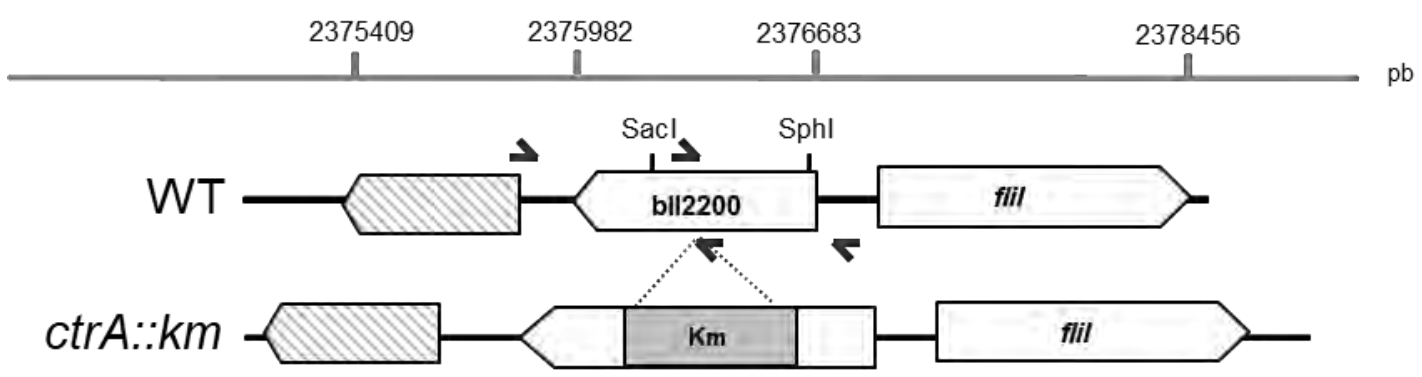

Figura IV.5 - Mapa esquemático de ctrA y genes vecinos (cluster 2) que muestra el diseño utilizado para su mutagénesis. Se amplificó mediante PCR un fragmento de la región $5^{\prime}$ y otro de la región $3^{\prime}$ del gen. Estos fragmentos fueron clonados con un gen de resistencia a $\mathrm{Km}$ entre ambos, quedando el gen interrumpido. Los símbolos rayados son genes que no guardan relación con ningún componente flagelar.

Se amplificó por PCR un fragmento del gen ctrA de 655 pb del genoma de $B$. diazoefficiens USDA 110 (entre las bases 2.375 .809 y 2.376.463) con los primers 2200_Fw2E y 2200_RvH. Ese fragmento fue digerido con las enzimas EcoRI (sitio incluido en uno de los primers) y Sacl (sitio que se encuentra en el genoma). Este fragmento de 400 pb fue clonado en el plásmido suicida en rizobios pG18mob2, obteniéndose la construcción pG::2200Up. La misma fue chequeada por PCR utilizando primers universales M13_Fw-M13_Rv y corroborados por digestión utilizando las enzimas de restricción EcoRI-Sacl, los cuales liberaron el fragmento de 400pb (Figura IV.6-B.1).

Paralelamente, se realizó la amplificación de la otra región del gen comprendida entre las bases 2.376.266 y 2.376 .887 utilizando los primers Dw2200_FwP y Dw2200_Rv mediante PCR. Para esta reacción se utilizó una polimerasa que deja extremos romos. Este fragmento de $622 \mathrm{pb}$ fue clonado en el sitio de restricción EcoRV en el vector de entrada pBlueScriptSK(+). Esta construcción se llamó pBS::2200Dw y fue chequeada por PCR utilizando primers universales M13_Fw y M13_Rv y verificada por digestión con la enzima de restricción BamHI, que posee un sitio de reconocimiento en el sitio de clonado multiple (SCM) del vector y uno dentro del fragmento de interés liberando un fragmento de 531 pb (Figura IV.6-B.2). A partir del vector $\mathrm{pBS}:$ :2200Dw se liberó el inserto utilizando las enzimas Pstl (sitio incluido en el primer) y Sphl (del genoma) y el fragmento de 419 pb fue subclonado en el plásmido pG::2200Up para obtener la construcción pG::2200UpDw. Este plásmido fue 
chequeado por PCR y digestión utilizando las enzimas Sacl (ubicada dentro del fragmento Up) y HindIII del SCM liberando un fragmento de 464 pb (Figura IV.6-C).

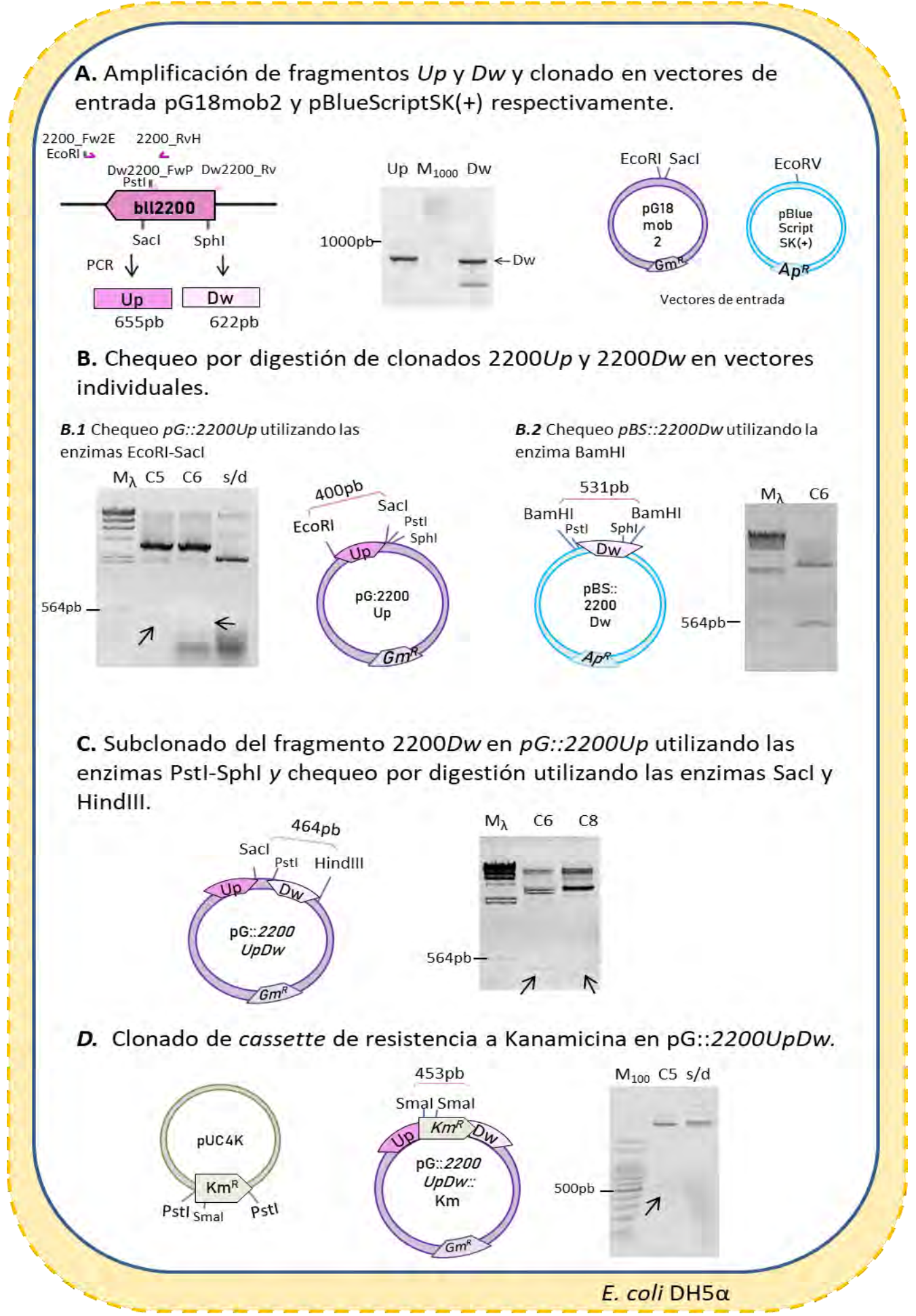

Figura IV.6 - Esquema del clonado para la obtención de la cepa mutante de $B$. diazoefficiens ctrA:: $\mathrm{Km}$. El gráfico muestra los pasos experimentales realizados para obtener la construcción pG::2200::Km. Up y Dw representan los fragmentos de bll2200 amplificados. En los geles de agarosa $M_{1000}, M_{100}$ y $M_{\lambda}$ representan los marcadores de peso molecular de $1000 \mathrm{pb}, 100 \mathrm{pb} \circ \lambda$ HindIII respectivamente. Con la letra $C$ y un número se indican diferentes clones chequeados por digestión con enzimas de restricción durante las construcciones (B, C y D). s/d indica el plásmido sin digerir. 
Finalmente, a esta última construcción se le introdujo el cassette de resistencia a $\mathrm{Km}$ proveniente del plásmido pUC4K, en el sitio Pstl y se corroboró la inserción por digestión con la enzima Smal que libera un fragmento de 453 pb (Figura IV. 6-D). Así, obtuvimos el plásmido pG::2200::Km. Mediante la secuenciación del inserto de dicho plásmido pudimos corroborar que lleva los fragmentos homólogos de las regiones 5 ' y 3' de ctrA interrumpidas por el cassette de resistencia a Km. En la Figura IV.6 se muestran los pasos de clonación en detalle.

Posteriormente, intentamos transferir esta construcción a $B$. diazoefficiens USDA 110 con el fin de obtener el mutante mediante recombinación homóloga, como describimos anteriormente. Sin embargo, y a pesar de haberse realizado varias conjugaciones cambiando las condiciones experimentales, los intentos de mutagénesis del ctrA putativo no fueron exitosos.

\section{IV.4 Obtención de una cepa mutante de $B$. diazoefficiens en la posible quinasa (CckA) de CtrA}

La estrategia de mutación que se utilizó para este gen fue la estrategia insercional (Capítulo II.4.9b). Para esto se amplificó un fragmento de bll5808 (gen homólogo a cckA de C. crescentus), y se clonó un cassette de resistencia a antibiótico aprovechando el sitio Xhol presente en su secuencia (Figura IV.7).

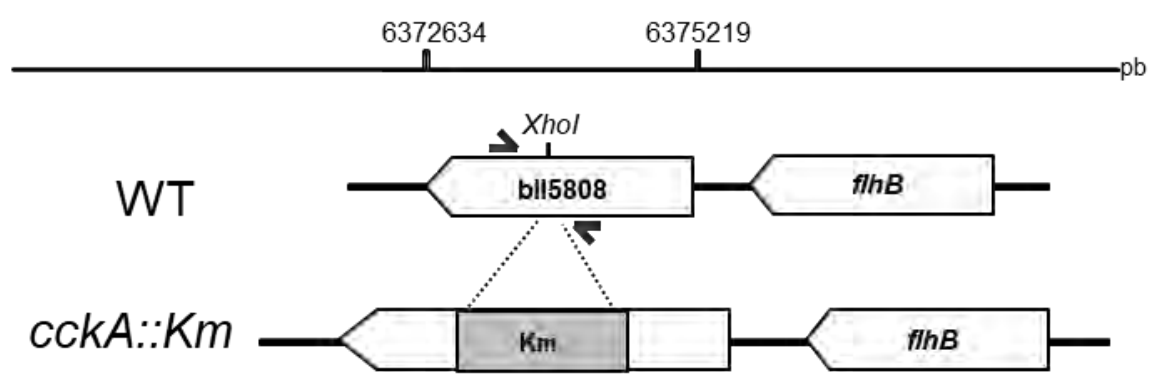

Figura IV.7 - Mapa esquemático del gen cckA (bll5808) y genes vecinos (c/uster 5) que muestra el diseño utilizado para su mutagénesis. La estrategia consistió en amplificar el gen por PCR y clonar en su sitio Xhol un cassette de resistencia a kanamicina (Km).

Para comenzar, se amplificó un fragmento de cckA de 649 pb del genoma de $B$. diazoefficiens USDA 110 (entre las bases 6.373 .532 y 6.374.182) utilizando los primers 5808_FwH y 5808_RvB (Figura IV.8-A). Este fragmento se clonó en el plásmido pG18mob2 utilizando las enzimas de restricción HindIII y BamHI agregadas en los primers obteniéndose el vector pG::5808. El clonado fue chequeado por PCR con primers universales M13_Fw y M13_Rv y corroborrado por digestión con las enzimas 
utilizadas para el clonado (Figura IV.8-B). Finalmente, el plásmido pG::5808 fue linealizado con la enzima Xhol presente en el inserto y en ese sitio se clonó el cassette de resistencia a $\mathrm{Km}$ liberado del plásmido pUC4K utilizando la enzima de restricción Sall. Las enzimas de restricción Sall y Xhol generan extremos compatibles que permiten la ligación pero no la restitución de los sitios de reconocimiento de las mismas (Figura IV.8-C). Este plásmido (pG::5808::Km), fue chequeado por digestión con las enzimas EcoRI presente en el plásmido y la enzima Xhol, cuyo sitio de ubica cerca del extremo 5 ' del cassette de resistencia a Km, De este modo se liberó un fragmento de $1.424 \mathrm{pb}$. (Figura IV.8-C). Este vector fue comprobado por secuenciación y movilizado a $B$. diazoefficiens mediante conjugación. Sin embargo, al igual que con ctrA la obtención de mutantes en el gen que codifica la quinasa cckA resultó infructuosa.

\section{IV.5 Efecto de la sobreexpresión de CtrA sobre la síntesis flagelar}

Dada la dificultad planteada en la obtención de los mutantes en ctrA, planteamos la caracterización de una cepa de $B$. diazoefficiens USDA 110 que lleva un plásmido que genera una sobreexpresión de ctrA.

Para realizar la sobreexpresión de CtrA, se amplificó el gen completo del genoma de B. diazoefficiens USDA 110 (entre las bases 2.375 .809 y 2.376.887) utilizando los primers 2200_Fw2E y Dw2200_Rv. Este fragmento de 1.079 pb fue digerido con las enzimas EcoRI-BamHI y clonado en el plásmido pFAJ1708 (replicativo en rizobios). El vector obtenido (pFAJ::2200) fue chequeado por digestión con las enzimas Hindlll-Sacl (liberando dos fragmentos de 1.424 pb y 410 pb-Figura IV.9-A) y corroborado mediante secuenciación. El plásmido fue transferido a $B$. diazoefficiens USDA 110 mediante conjugación biparental y las colonias resistentes al antibiótico Tc fueron chequeadas por PCR usando los primers del vector denominados pFAJ_Fw y pFAJ_Rv (Figura IV.9-B). Así, obtuvimos una cepa que sobreexpresa CtrA, la cual denominamos Bd-pFAJ::ctrA (por Bradyrhozobium diazoefficiens que contiene el plásmido pFAJ::2200). Mediante qRT-PCR se corroboró que $B d$-pFAJ::ctrA posee 8 veces más cantidad de ARNm de ctrA que la cepa de $B$. diazoefficiens que contiene el plásmido vacío (Bd-pFAJ) (Figura IV.12). Esto indicaría que la sobreexpresión del gen se logró en forma exitosa. 


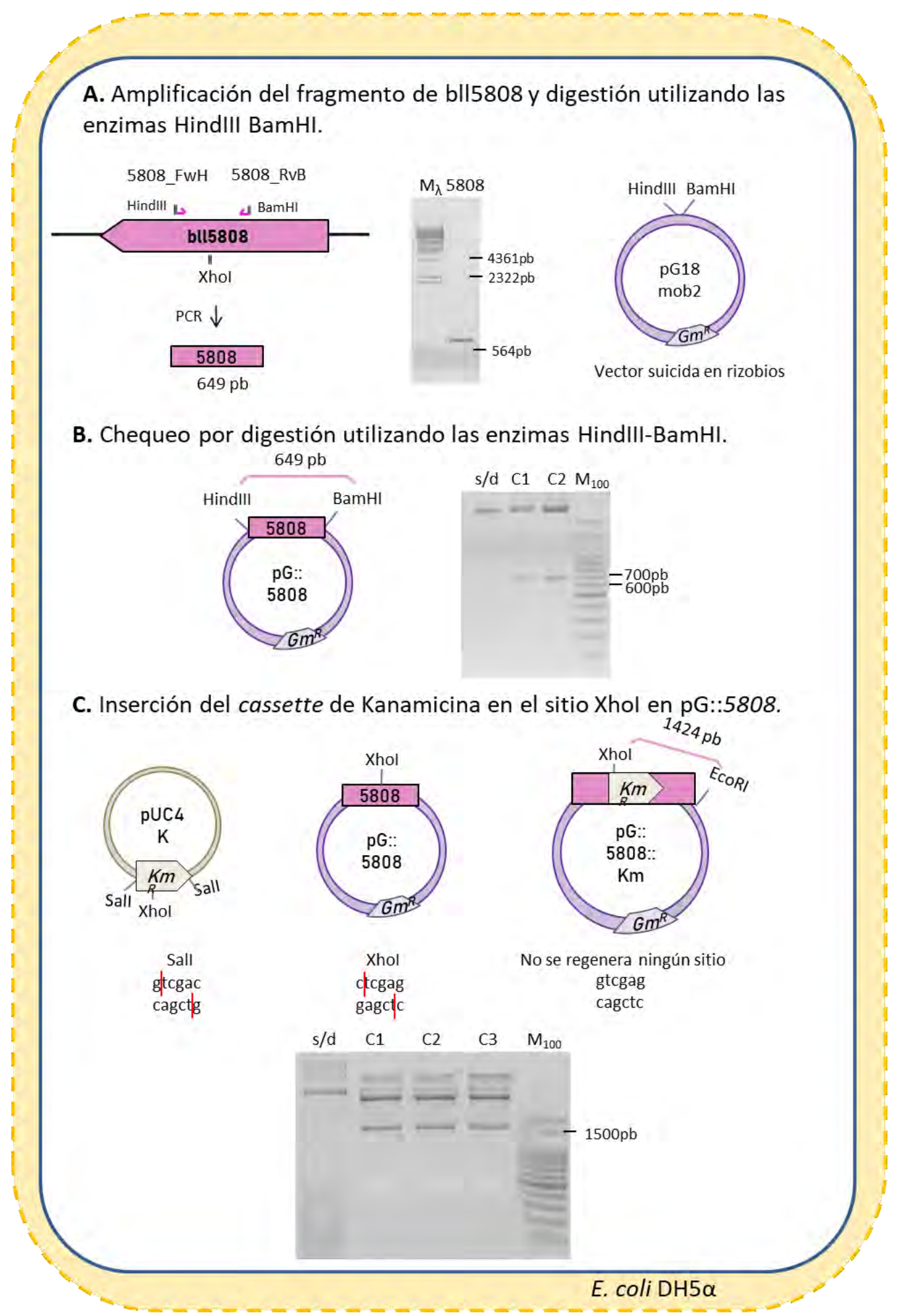

Figura IV.8 - Esquema del clonado para la obtención de la cepa mutante de $B$. diazoefficiens cckA::Km. El gráfico muestra los pasos experimentales realizados para obtener la construcción pG::5808::Km 5808 representa el fragmento de bll5808 amplificado. En los geles de agarosa $\mathrm{M}_{100}$ y $\mathrm{M}_{\lambda}$ representan los marcadores de peso molecular de $100 \mathrm{pb}$ o $\lambda$-HindIII respectivamente. Con la letra $\mathrm{C}$ y un número se indican diferentes clones chequeados por PCR durante las construcciones (B y $C)$. s/d se refiere al plásmido sin digerir. 
A. Clonado de bll2200 en pFAJ1708 y chequeo por digestión con enzimas HindIII-Sacl.

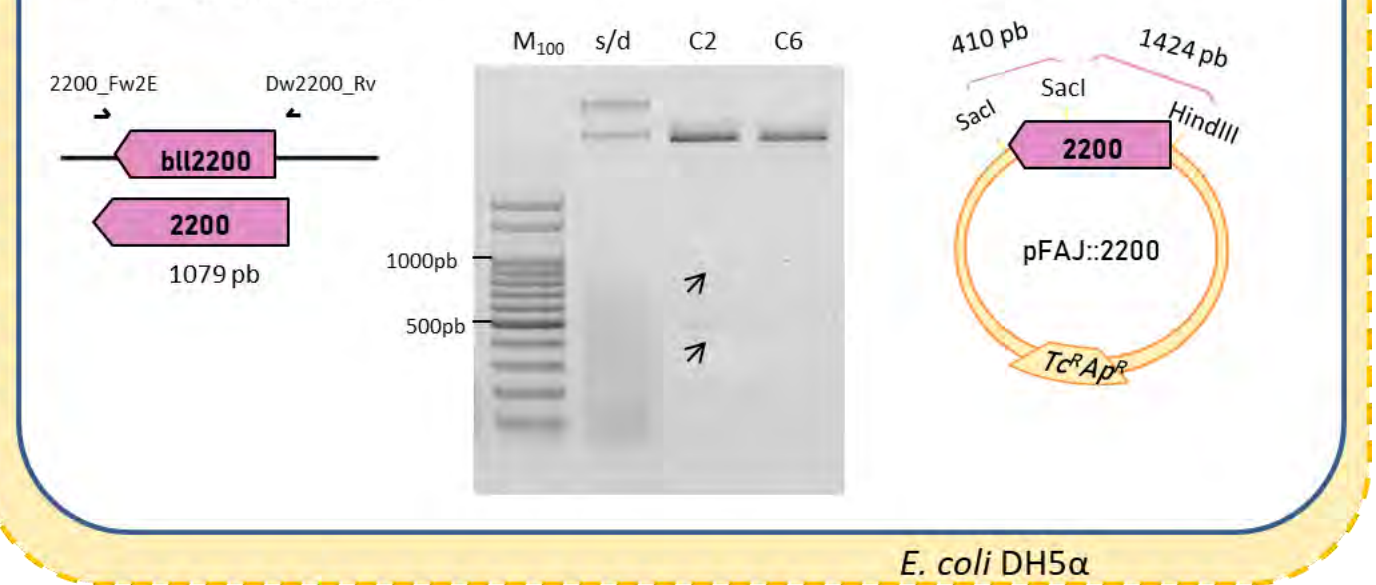

B. Chequeo de introducción del plásmido en B. diazoefficiens.

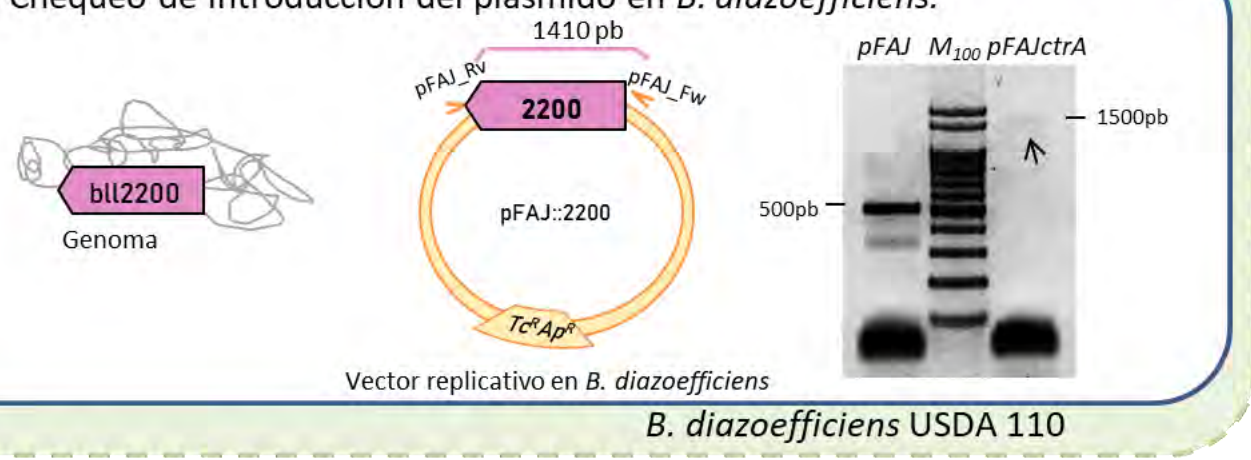

Figura IV.9 - Esquema del clonado y selección de la cepa que sobreexpresa CtrA ( $B d$ pFAJ::ctrA). El gráfico con el recuadro amarillo muestra el clonado para obtener el plásmido pFAJ::2200 y el gráfico con el recuadro verde muestra los pasos realizados para obtener la cepa de $B$. diazoefficiens que sobreexpresa CtrA ( $B d$-pFAJ::ctrA).En los geles de agarosa $M_{100}$ representa el marcador de peso molecular de $100 \mathrm{pb}$. Con la letra $\mathrm{C}$ y un número se indican diferentes clones chequeados por digestión durante las construcciones (A). s/d se refiere al plásmido sin digerir. pFAJ representa la PCR utilizando el plásmido pFAJ1708 y pFAJ::ctrA la PCR del clon que contiene el plásmido pFAJ::2200.

\section{IV.5.1 Caracterización fenotípica de la cepa $B d$-pFAJ::ctrA}

Inicialmente, para comenzar la caracterización de la cepa que sobreexpresa CtrA, analizamos su crecimiento en medio líquido. Para esto se cultivó la cepa $B d$-pFAJ::ctrA y $B d$ pFAJ en el medio $A G$ durante 7 días. Se tomaron muestras de los cultivos diariamente, y a cada una se le determinó la biomasa total por medida de la densidad óptica a $500 \mathrm{~nm}\left(\mathrm{DO}_{500}\right)$ y el número de células viables por recuento en placa de las UFC (esta última medida se realizó en placas con y sin agregado del antibiótico que otorga la presencia del plásmido (Tc). Se realizaron dos experimentos independientes, los cuales mostraron resultados similares; a continuación, expondremos los resultados obtenidos en uno de ellos. 
En la Figura IV.10 puede observarse que ambas cepas mostraron cinéticas de crecimiento similares, tanto en la biomasa total estimada por densidad óptica a 500 $\mathrm{nm}$. $\left(\mathrm{DO}_{500}\right)$ o en el recuento de unidades formadoras de colonias (UFC), y en ninguno de los dos casos se observó la pérdida de los plásmidos pFAJ1708 y pFAJ::ctrA, los cuales se mantuvieron estables (Figura IV.10-B). Dado el posible rol de CtrA sobre el proceso de división celular, realizamos observaciones de $B d$-pFAJ::ctrA al microcopio óptico, pero no detectamos diferencias morfológicas ni en fase exponencial ni en fase estacionaria (Figura IV.10-C).

$\boldsymbol{A}$

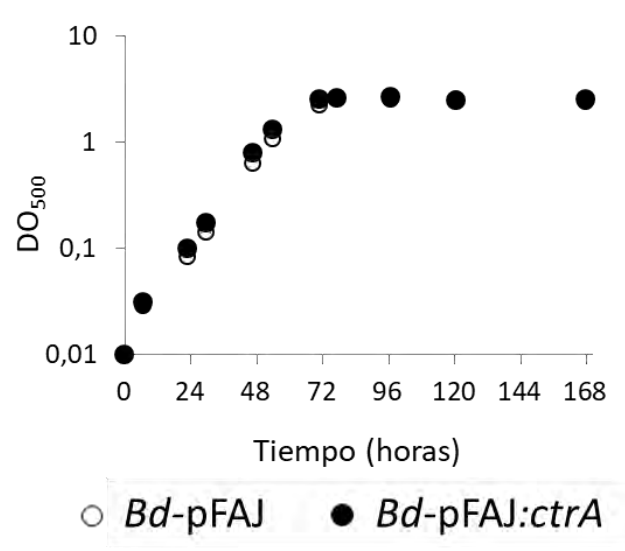

C
B

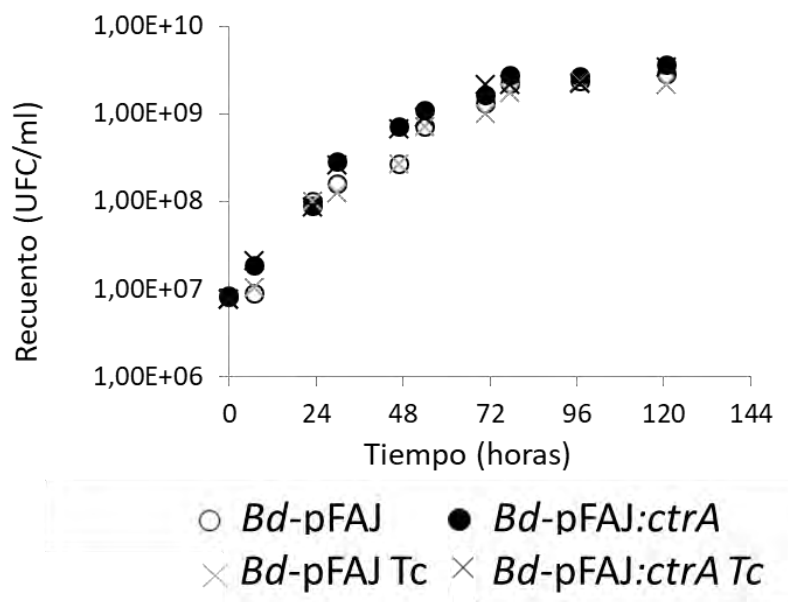

$B d$-pFAJ:ctrA

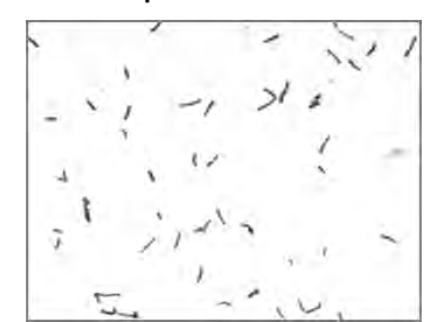

Figura IV.10 - Cinética de crecimiento de la cepa Bd-pFAJ::ctrA. A. Crecimiento de $B$. diazoefficiens en medio líquido $A G$ conteniendo el plásmido vacío y el plásmido con ctrA ( $B d$ pFAJ y $B d-$ pFAJ::ctrA, respectivamente) mediante medidas de densidad óptica (A) y estimación del número de células viables por recuento en placa (B) con o sin antibiótico (Tc) . C. Imágenes al microscopio óptico $(1.000 \mathrm{x})$ de las cepas crecidas en medio PSY-ara y luego teñidas con cristal violeta.

A continuación, realizamos una extracción de flagelinas extracelulares del mismo sobrenadante de cultivo obtenido durante el experimento de las curvas de crecimiento. Como podemos ver en la Figura IV.11-A todas las cepas analizadas mostraron la presencia de flagelinas laterales y subpolares. Se puede ver que la cepa conteniendo ctrA en múltiples copias ( $B d$-pFAJ::ctrA) mostró niveles de proteínas considerablemente más bajos comparados con el control positivo (B. diazoefficiens USDA 110 y B. diazoefficiens llevando el plásmido vacío, Bd-pFAJ). Para evaluar la 
funcionalidad de los flagelos se realizó un ensayo de natación en agar semisólido de las diferentes cepas. En concordancia con los niveles de flagelina encontrados observamos que la capacidad de natación de la cepa que sobreexpresa ctrA se vio disminuida comparada con la cepa que posee el plásmido vacío (Figura IV.11-B).

A

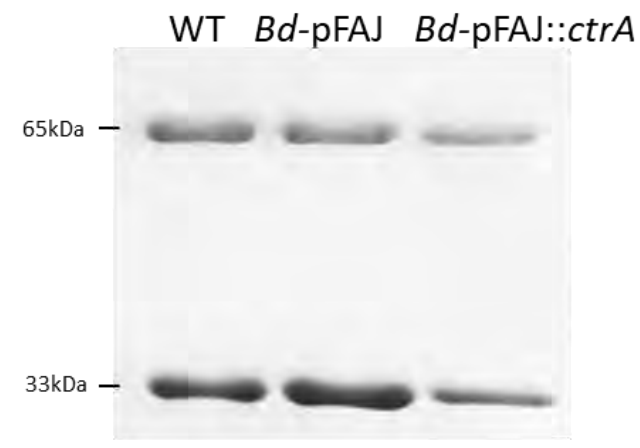

B
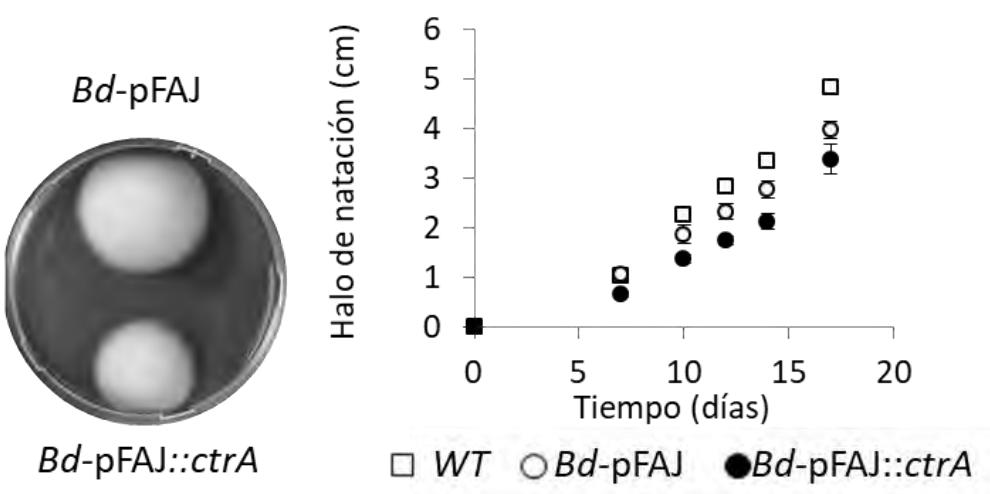

Figura IV.11 -Perfil de flagelinas (A) y ensayos de movilidad en agar semisólido (B) de la cepa de $B$. diazoefficiens que sobreexpresa ctrA. A. SDSPAGE de la extracción de proteínas extracelulares de la cepa que sobreexpresa ctrA, como control se utilizó la cepa que contiene el plásmido vacío ( $B d$-pFAJ) y como referencia, la cepa WT (B. diazoefficiens USDA 110). B. Ensayo de movilidad. A la izquierda se muestra una foto representativa de una placa de natación en agar semisólido a los 14 días después de la inoculación y a la derecha el registro del diámetro del halo de natacióna lo largo del tiempo.

Para corroborar la acción de CtrA como regulador maestro del flagelo subpolar realizamos la cuantificación del ARNm de algunos de los posibles genes diana. (Figura IV.12). Los genes elegidos fueron los posibles genes reguladores ( $f l b D, f l i X, f l a F, f l b T)$ que, además, poseen la caja regulatoria de CtrA (Figura IV.4). No pudimos detectar diferencias significativas en ninguno de los genes regulatorios que se encontrarían bajo el control de CtrA a niveles más bajos de la cascada regulatoria (Figura IV.12). 


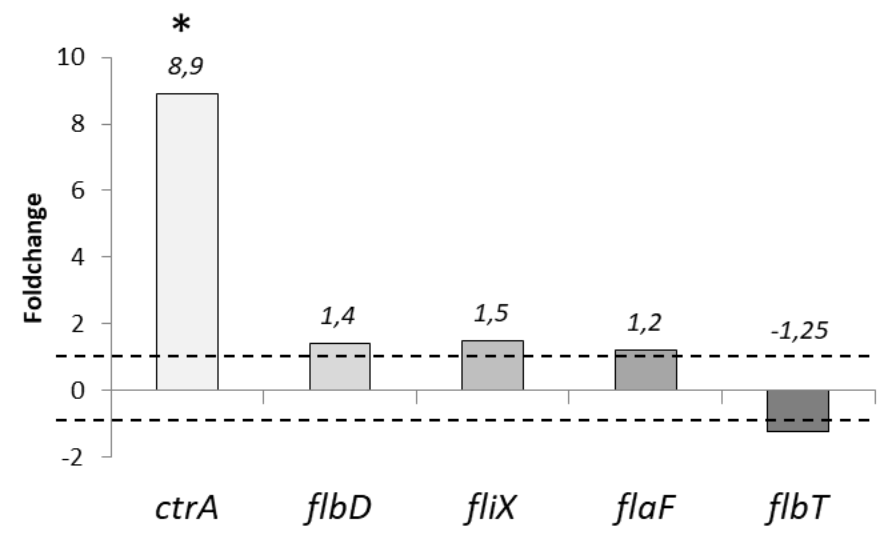

Figura IV.12 - Niveles de expresión de los transcriptos de los posibles reguladores flagelares en la cepa que sobreexpresa ctrA. Expresión relativa de los reguladores analizados expresados como foldchange de $B$. diazoefficiens conteniendo pFAJ::ctrA versus aquella conteniendo el plásmido vacío. Las líneas punteadas marcan los foldchange de \pm 1 , que representa los niveles de transcripto en la cepa que contiene el plásmido vacío. El asterisco representa diferencias significativas obtenidas a través del método $\Delta \Delta \mathrm{C}_{\mathrm{T}}$.

\section{IV.6 Conclusión y Perspectivas}

A partir de este análisis logramos identificar al gen que codifica CtrA junto con las numerosas proteínas que forman parte del sistema de señalización de CtrA en el genoma de $B$. diazoefficiens USDA 110 , indicándonos que esta vía regulatoria también se encuentra conservada en esta bacteria. A pesar de los intentos realizados para mutar ctrA y su quinasa $c c k A$, no hemos tenido éxito. Por lo tanto, suponemos que al igual que ocurre en otras bacterias (Quon et al., 1998; Barnett et al., 2001) y, consecuentemente con la información obtenida a partir del árbol filogenético, CtrA también podría estar involucrada en el proceso de división celular en $B$. diazoefficiens.

En otros microorganismos donde la mutación de CtrA es inviable, se ha desarrollado una estrategia alternativa para analizar su función. Esta consiste en la mutación del gen sumada a la expresión en trans de CtrA a través de un promotor inducible (Pini et al., 2015). De esta manera, se logra una expresión transitoria del gen candidato y se pueden estudiar sus efectos in vivo. Utilizando esta misma aproximación podríamos frenar la inducción de CtrA temporariamente y así conseguir analizar el fenotipo. Hasta el momento no contamos con un vector de este tipo que sea funcional en $B$. diazoefficiens por lo que resulta aún más complicado este abordaje.

Durante este trabajo hemos identificado in silico algunos genes diana que contienen la secuencia consenso TTAACCAT en las regiones promotoras de algunos genes de $B$. japonicum USDA 6. Además, identificamos esta secuencia de reconocimiento de $\mathrm{Ctr}$ A en genes relacionados con la formación del flagelo subpolar de $B$. japonicum USDA 6, los cuales fueron corroborados en B. diazoefficiens USDA 110, lo que podría indicar que en estas bacterias CtrA también podría ser un regulador de la síntesis del flagelo subpolar. 
Para evidenciar experimentalmente la función de CtrA como regulador maestro de la síntesis del flagelo subpolar en $B$. diazoefficiens realizamos la sobreexpresión del gen. A pesar de que observamos un aumento significativo en la cantidad de transcripto de ctrA, y una disminución en la capacidad de natación de la cepa que sobreexpresa el gen, no pudimos detectar un efecto sobre la transcripción de genes que estarían bajo su regulación en la cascada de síntesis del flagelo subpolar. Es probable que, si bien los niveles de ARNm de ctrA se encuentran aumentados, el transcripto no se esté traduciendo en un aumento en la cantidad de proteína. Incluso podría suceder que los niveles de CtrA-P no aumenten producto de la sobreexpresión del gen, y por lo tanto no se genere ningún efecto sobre la transcripción de genes flagelares. Sin embargo, la movilidad se vio considerablemente afectada en la cepa que sobreexpresa CtrA. Con motivo de comprobar la unión de CtrA a las cajas promotoras de los genes del flagelo subpolar podrían realizarse otro tipo de experimentos como por ejemplo geles de retardo (EMSA) o experimentos de pulldown de CtrA seguida de secuenciación. Sin embargo, al momento no contábamos con herramientas suficientes para encarar estos aspectos, por lo cual decidimos continuar con el análisis de los otros reguladores de la síntesis del flagelo subpolar de $B$. diazoefficiens.

En el siguiente Capítulo desarrollaremos el análisis funcional de los genes blr7003 y bll5837, los cuales codifican los reguladores de clase II (FlbD-FliX) y suceden a CtrA en la cascada regulatoria en el modelo de $C$. crescentus. 


\section{IV.7Anexo}

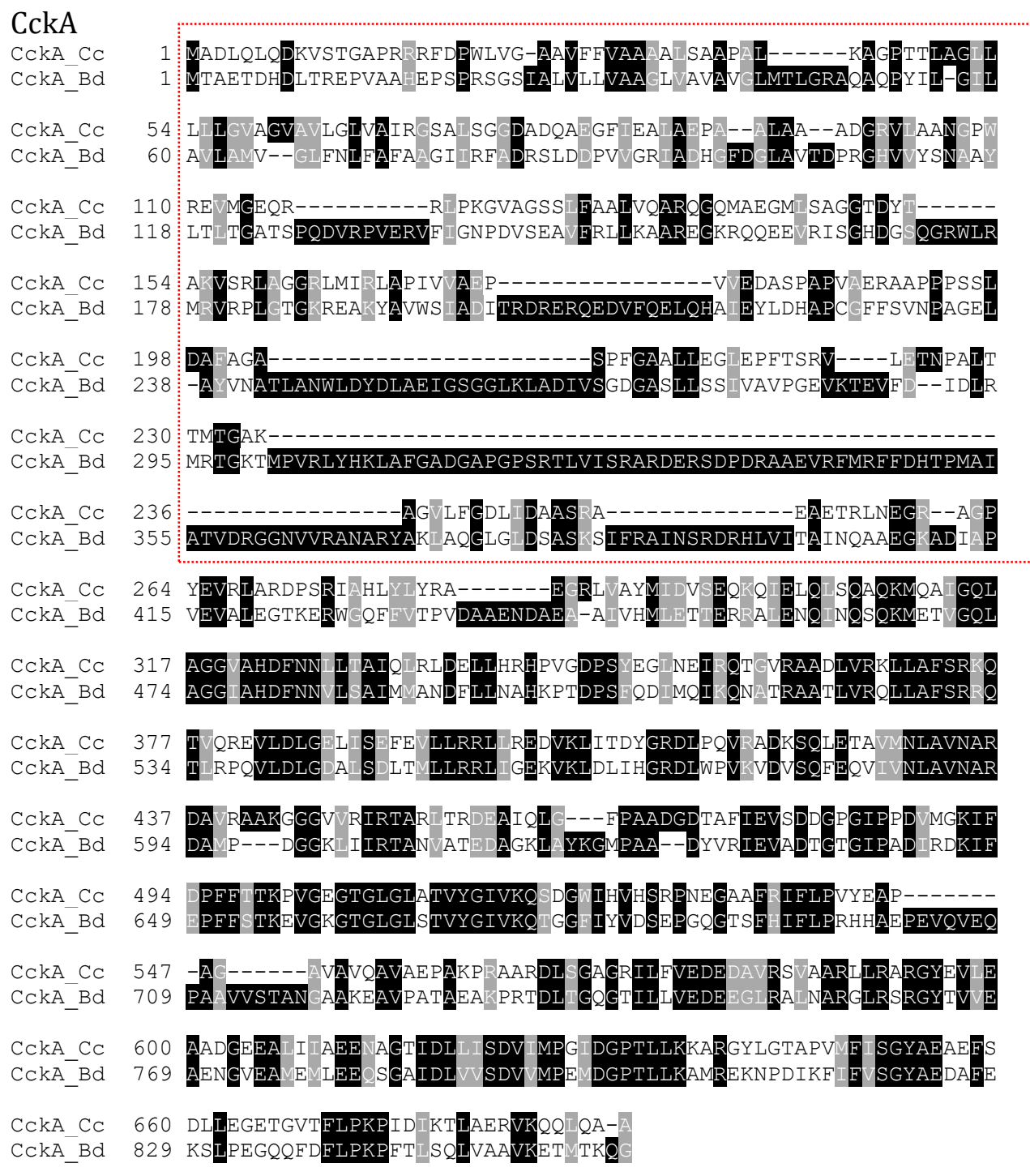

PleC

$\mathrm{PleC} \mathrm{Cc}$

$\mathrm{PleC}_{-}^{-} \mathrm{Bd}$

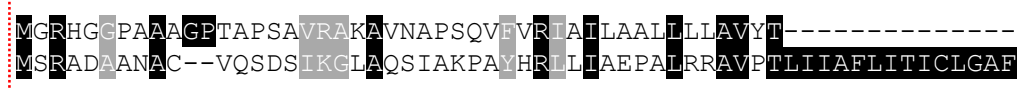

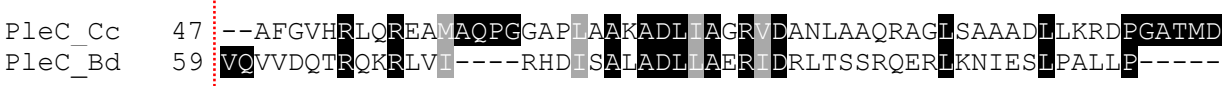

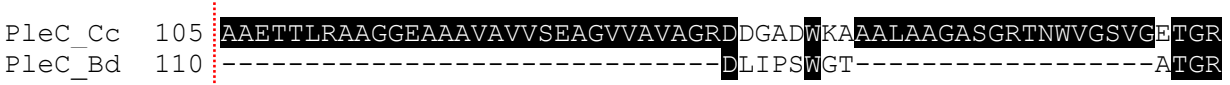

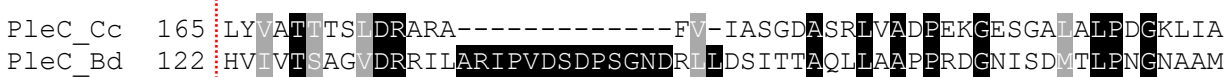

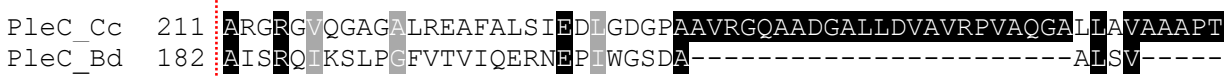

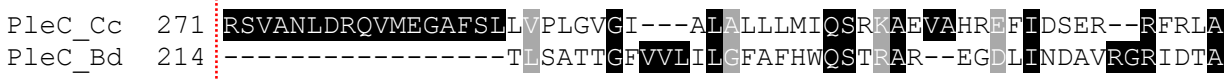

$\begin{array}{ll}\text { PleC_CC } & 326 \text { VEA RCG W WDINGDQVYLSDVTGAMFGWGGGGVV--SG--DDLERISIDHRERVRQA } \\ \text { PleC_Bd } & 255\end{array}$

PleC_CC 382 IANAAMYGAFDVFR PAS QGARSWIDARGQGFGEGSEGHARIIG A DVTEERIAQ 


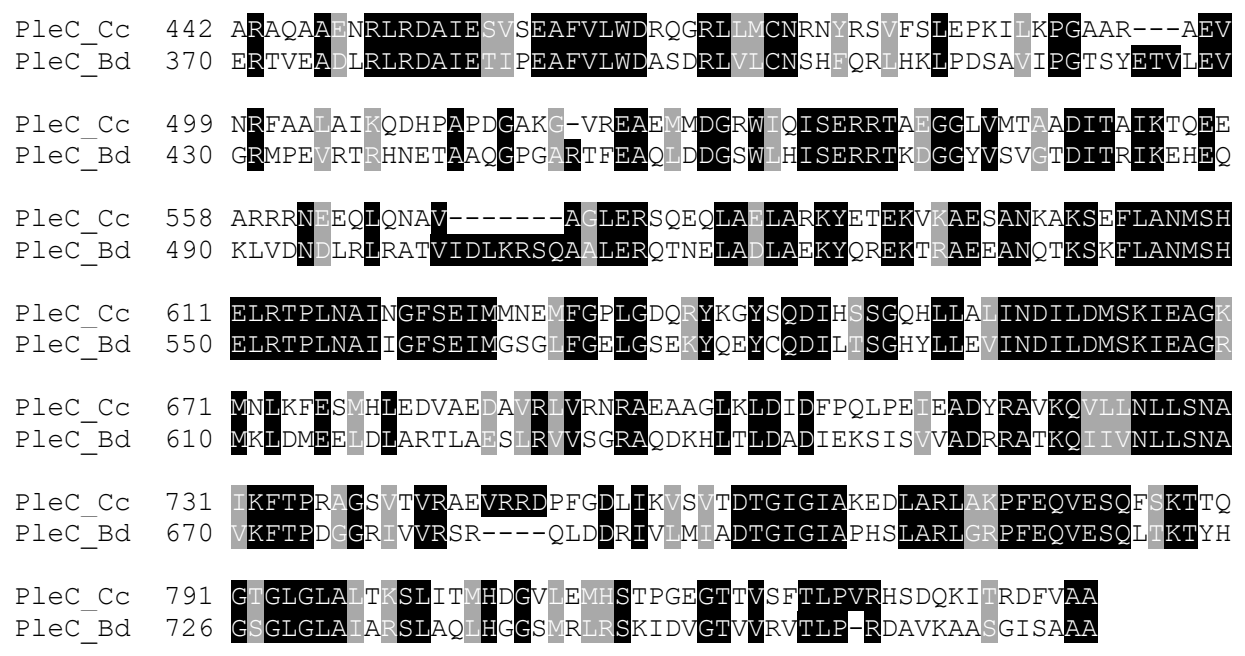

DivJ
DivJ_CC
DivJ_Bd

Figura AIV.1 - Alineamientos de CckA/PleC/DivJ presentes en $C$. crescentus y $B$. diazoefficiens. En rojo se recuadra la región variable correspondiente al dominio sensor. 
Tabla AIV.1 - Tabla con los genes que poseen la secuencia TTAACCAT en su región promotora encontrada a través del servidor MEMEsuite.

\begin{tabular}{|c|c|c|c|}
\hline $\begin{array}{l}\text { Locus } \\
\text { tag }\end{array}$ & Función de la proteína & $\begin{array}{l}\text { Locus } \\
\text { tag }\end{array}$ & Función de la proteína \\
\hline blr0835 & polysaccharide export protein & blr0400 & \\
\hline blr0960 & $\begin{array}{l}\text { s-methyl-5'-thioadenosine } \\
\text { phosphorylase MtnP }\end{array}$ & blr0547 & GnaT family $N$ acetiltransferasa \\
\hline blr3362 & $\begin{array}{l}\text { lipopolysaccharide biosynthesis } \\
\text { protein }\end{array}$ & blr0642 & calcium-binding protein \\
\hline bll7745 & & blr0671 & $\begin{array}{l}\text { Penicillin-binding protein } \\
\text { activator }\end{array}$ \\
\hline bll7529 & & blr2728 & \\
\hline bll1533 & chemotaxis protein & bll1129 & FAD-binding dehydrogenase \\
\hline bll7155 & $\begin{array}{l}\text { tol-pal system protein TolQ } \\
\text { invaginación } \\
\text { división celular }\end{array}$ & blr7447 & \\
\hline bll5919 & & bll7408 & $\begin{array}{l}\text { phosphoglucosamine mutase } \\
\text { GlmM }\end{array}$ \\
\hline bll5886 & histidine kinase & blr7296 & \\
\hline bll5851 & & blr7232 & L,D-transpeptidase \\
\hline bll5520 & transglycosylase & bll7151 & EAL domain-containing protein \\
\hline $\begin{array}{l}\text { blr0367 } \\
\text { bsl5256 }\end{array}$ & fad binding protein & $\begin{array}{l}\text { blr7099 } \\
\text { bll7051 }\end{array}$ & \\
\hline bll4866 & dna-directed dna polymerase & bll7011 & $\begin{array}{l}\text { sulfonate } A B C \text { transporter } \\
\text { substrate-binding protein }\end{array}$ \\
\hline bsl4812 & pilus assembly protein & blr6759 & $\begin{array}{l}\text { decarboxylating } \\
\text { phosphogluconate } \\
\text { dehydrogenase }\end{array}$ \\
\hline bll4323 & & blr6582 & murein L,D-transpeptidase \\
\hline bll4107 & permease Ips export & bll5565 & \\
\hline bll3753 & & bll3595 & \\
\hline bll1440 & pilus assembly protein $\mathrm{CtpC}$ & bll5945 & $\begin{array}{l}\text { methionine adenosyltransferase } \\
\text { MetK }\end{array}$ \\
\hline bll0167 & & blr5887 & Apolipoprotein A1/A4/E \\
\hline bll0546 & alpha/beta fold hydrolase & bll5866 & $\begin{array}{l}\text { ferritin-like domain-containing } \\
\text { protein }\end{array}$ \\
\hline bsl0551 & YggT family protein & blr5867 & \\
\hline bll0786 & $\begin{array}{l}\text { ribosome maturation factor } \\
\text { RimP }\end{array}$ & blr5502 & \\
\hline bll1032 & $\begin{array}{l}\text { c4-dicarboxylate } \\
\text { protein }\end{array}$ & bll5268 & \\
\hline blr8110 & DNA recombination RmuC & blr5269 & $\begin{array}{l}\text { Two-component hybrid sensor } \\
\text { and regulator }\end{array}$ \\
\hline blr5636 & & blr4759 & $\begin{array}{l}\text { iron-sulfur cluster insertion } \\
\text { protein ErpA }\end{array}$ \\
\hline
\end{tabular}




\begin{tabular}{|c|c|c|c|}
\hline blr4974 & $\begin{array}{l}\text { polysaccharide biosynthesis } \\
\text { glycosyltransferase }\end{array}$ & bll4587 & malonate transporter \\
\hline blr4211 & $\begin{array}{l}\text { Septum formation inhibition } \\
\text { MinC }\end{array}$ & blr4488 & NtrC \\
\hline blr3797 & $\begin{array}{l}\text { phosphatidylserine synthase } \\
\text { PssA }\end{array}$ & blr4435 & \\
\hline blr2642 & & bll4347 & domain-containing \\
\hline blr1506 & $\begin{array}{l}\text { AraC family transcriptional } \\
\text { regulator }\end{array}$ & blr4306 & $\begin{array}{l}N \text {-acetylmuramoyl-L-alanine } \\
\text { amidase }\end{array}$ \\
\hline bsr8446 & $\begin{array}{l}\text { AlpA family phage regulatory } \\
\text { protein }\end{array}$ & $\begin{array}{l}\text { bsr423 } \\
6\end{array}$ & \\
\hline bll2200 & CtrA & blr4048 & $\begin{array}{l}\text { 3-methyl-2-oxobutanoate } \\
\text { hydroxymethyltransferase }\end{array}$ \\
\hline blr5847 & FlbT & bll3434 & $\begin{array}{ll}\text { Transcriptional regulatory } \\
\text { protein MarR family }\end{array}$ \\
\hline bll5837 & Flix & bll3250 & \\
\hline bll5826 & FliL & bll3140 & $\begin{array}{l}\text { Two-component sensor } \\
\text { histidine kinase }\end{array}$ \\
\hline bll5814 & FlgB & blr2816 & aldehyde dehydrogenase \\
\hline blr6999 & FliF & blr2422 & Putative efflux protein \\
\hline & & bll2353 & $\begin{array}{l}\text { antibiotic resistance protein } \\
\text { Vanz }\end{array}$ \\
\hline & & bll2176 & $\begin{array}{l}\text { two-component hybrid sensor } \\
\text { and regulator }\end{array}$ \\
\hline & & bll2063 & NrgC Acyl-CoA dehydrogenases \\
\hline & & bll6620 & $A B C$ transporter \\
\hline & & blr7887 & \\
\hline & & bll7921 & $\begin{array}{l}A B C \text { transporter substrate- } \\
\text { binding protein }\end{array}$ \\
\hline & & blr1151 & DMT family transporter \\
\hline & & bll8196 & porin family protein \\
\hline & & blr2201 & Flil \\
\hline
\end{tabular}

Las dos columnas de la izquierda muestran los genes de $B$. japonicum USDA 6 para los que se encontró la caja TTAACCAT en sus promotores con un valor $p=3,6$ y las dos columnas de la derecha con un valor $p=1,9$. Con rosa se resaltaron genes flagelares que contienen estas secuencias promotoras y en azul genes relacionados con la división celular. 
Capítulo V: Caracterización de los reguladores de clase II (FlbD-FliX) de la cascada de síntesis del flagelo subpolar de $B$. diazoefficiens USDA 110 



\section{V.1 Introducción}

Luego del control ejercido por el regulador maestro CtrA, la cascada regulatoria flagelar descripta para $C$. crescentus continúa con otros dos reguladores, denominados FlbD y FliX. Estas dos proteínas se denominan reguladores de clase II, y son las encargadas de comenzar la segunda etapa de la síntesis del flagelo, activando la transcripción del siguiente grupo de genes denominados de clase III y IV.

\section{Rol de FlbD, FliX y $\sigma^{54}$ sobre la transcripción génica}

FlbD es una Enhancer Binding Protein (EBP) cuya función es activar la transcripción mediante el estímulo de la apertura de las hebras de ADN del complejo ARN polimerasa- $\sigma^{54}$ (Smith y Hoover, 2009). Esta proteína posee tres dominios característicos necesarios para promover la transcripción génica. Uno de ellos es un dominio sensor (REC) que se encuentra ubicado en la región $\mathrm{N}$-terminal de la proteína. Este dominio posee un residuo aspartato conservado que puede de ser fosforilado por una proteína histidina quinasa específica (Ramakrishnan y Newton, 1990), de acuerdo a señales internas o ambientales. Como consecuencia de esta fosforilación, las EBP cambian su conformación, se oligomerizan y activan su dominio central denominado AAA+. Este dominio es capaz de degradar ATP para abrir el complejo ARN polimerasa$\sigma^{54}$. El tercer dominio, situado en el extremo C-terminal, interviene en la unión a ADN, y su función es fundamental para el reconocimiento y la unión de la proteína a regiones específicas de ADN que, en general, se encuentran alejadas de los marcos de lectura abiertos (ORF) que regulan.

La unión de esta EBP, junto con la acción de otra proteína, denominada IHF (Integration Host Factor), permiten que el elemento de transcripción que se encuentra alejado de los genes que regula, pueda acercarse al complejo ARN polimerasa- $\sigma^{54}$ (Muir et al., 2005). Sólo así la energía proveniente de la hidrólisis del ATP podrá ser transferida al complejo transcripcional para separar las hebras de ADN e iniciar la transcripción de los genes que se encuentran corriente abajo.

El otro protagonista en esta etapa de regulación es FliX, una pequeña proteína citosólica que actúa como regulador en trans de FlbD. No posee ningún dominio característico, pero es capaz de unirse a FlbD y modular su acción tanto positiva como negativamente (Mohr et al., 1998, Xu et al., 2011). Además, cuando ambas proteínas están unidas, se favorece la estabilidad del complejo (Muir y Gober, 2004; Muir y Gober, 2005). FliX no solo es capaz de unirse a FlbD y modular su función, sino que también podría encontrarse asociada a la membrana bacteriana y de esta manera participaría en el mecanismo de percepción del estado de formación del flagelo (Muir y Gober, 2002). Así, FliX actuaría como un checkpoint, es decir, promovería la transcripción de genes de la tercera etapa de la síntesis del flagelo sólo si la estructura previa se encuentra correctamente ensamblada. De lo contrario, impediría este 
proceso. El mecanismo mediante el cual FliX modula FlbD y percibe el estado de formación del flagelo aún continúa siendo una incógnita.

\section{Relación de FlbD y FliX con el ciclo celular}

Los niveles de FlbD y FliX no se encuentran sujetos a control del ciclo celular, aunque su actividad promotora varía durante el mismo (Mohr et al., 1998; Muir y Gober, 2002). En general, la expresión temporal de distintos factores $\sigma$ es fundamental en diversos procesos bacterianos, ya que le permite a la célula redirigir la maquinaria de transcripción génica de acuerdo a señales internas y/o externas (Helmann y Chamberlin, 1988). Esta variación en la acción promotora de FlbD y FliX podría deberse entonces a los Factores IHF y $\sigma^{54}$, los cuales son expresados en un momento determinado del ciclo celular y son necesarios para el accionar de FlbD.

Otra hipótesis que sería consecuente con la activación temporal de la transcripción de estos reguladores se centra en la posible fosforilación de FlbD en el dominio REC (cuya señal provendría del proceso de división celular más que de señales nutricionales o ambientales). Existen indicios que muestran esta fosforilación in vitro y un aumento de su actividad promotora, aunque no resultan del todo concluyentes (Wu et al., 1995). Además de ello, hasta el momento no ha sido posible encontrar una quinasa responsable de esta modificación post-traduccional (Wu et al., 1995). Lo que sí se conoce fehacientemente es que tanto la ausencia de FlbD como de FliX en $C$. crescentus generan grandes defectos en la citoquinesis, provocando la aparición de células filamentosas (Muir et al., 2005). Esto demuestra una interconexión muy fuerte entre los mecanismos de señalización de la división celular y la síntesis del flagelo en esta especie bacteriana.

\section{V.2 Análisis bioinformático de los posibles reguladores de clase II de la cascada de síntesis del flagelo subpolar en $B$. diazoefficiens}

Para comenzar la caracterización de estas dos proteínas, realizamos una búsqueda mediante BLASTp de los posibles reguladores de clase II, FlbD y FliX, en el genoma de la cepa de referencia $B$. diazoefficiens USDA 110.

En las Figuras V.1 y V.2 se muestran los alineamientos de FlbD y FliX de $B$. diazoefficiens y $C$. crescentus, las cuales serían proteínas homólogas (63/80\% y 44/65\% de similitud e identidad entre sí, respectivamente). Los genes que codifican estas proteínas, blr7003 (flbD) y bll5837 (fliX), se encuentran en los clusters 5 y 6 respectivamente, descriptos en el Capítulo III. Además, los genes bll5019 y blr0742 codificarían las subunidades $\alpha$ y $\beta$ de IHF y, los genes blr1883 (rpoN1) y blr0723 
(rpoN2), codifican dos copias del factor $\sigma^{54}$, tal como se caracterizó en trabajos previos (Kullik et al., 1991) y cuyos productos podrían participar en la función del par FlbD/FliX.

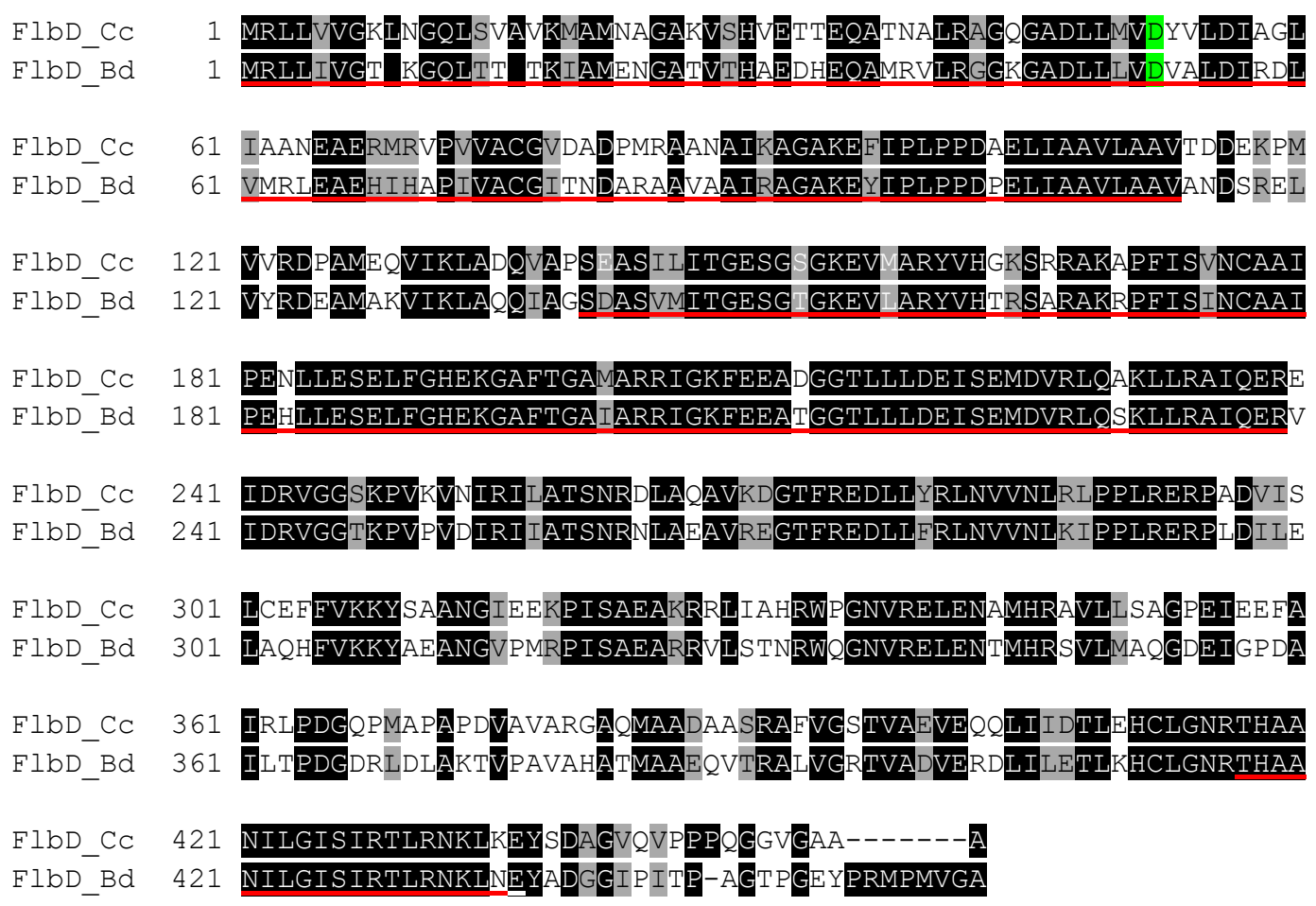

Figura V.1 - Alineamiento de FlbD de $C$. crescentus y B. diazoefficiens USDA 110. En negro se marcaron los aminoácidos idénticos y en gris los aminoácidos similares. En verde se marca el aminoácido D52 conservado susceptible defosforilación. En rojo se subrayaron los tres dominios característicos, los cuales son REC, AAA+ y HTH, (desde el extremo $\mathrm{N}$ al C-terminal, respectivamente).

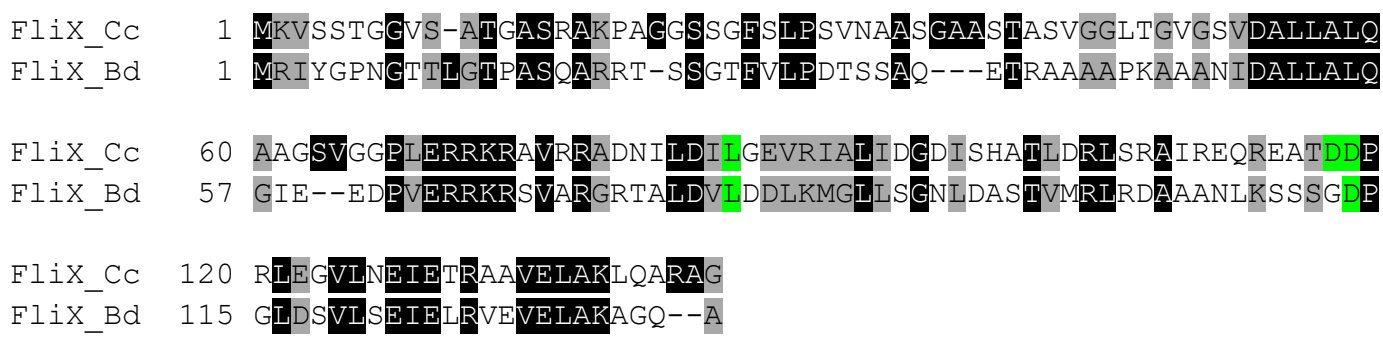

Figura V.2 - Alineamiento de FliX de $C$. crescentus y $B$. diazoefficiens USDA 110. En negro se marcaron los aminoácidos idénticos y en gris los aminoácidos similares. En verde se marcaron los aminoácidos necesarios para la interacción de FlbD-FliX en C. crescentus (Xu et al., 2011).

En C. crescentus se han determinado las secuencias de reconocimiento de FlbD, denominadas $f t r$. La secuencia consenso de esta caja es CCCGGCARNRNYTGCCGGG y se halla delante de genes de clase II, III y IV (Mullin et al., 1994, Benson et al., 1994). Aquellos genes que poseen esta secuencia conservada son regulados directamente por FlbD, e incluso aquellos que presentan más de una caja ftr son genes con una tasa mayor de transcripción (Wu et al., 1995). Al contrario, aquellos que poseen más variaciones de secuencia con respecto a la secuencia consenso ftr, suelen ser genes de clase II cuya transcripción no depende de FlbD o, en algunos casos, son regulados 
negativamente por ésta. Además de la conservación de secuencia de las cajas ftr, la distancia a la que se encuentran las mismas con respecto al promotor de $\sigma^{54}$ también resulta fundamental para la activación de la transcripción (Mullin et al., 1994).

Una búsqueda bioinformática utilizando la secuencia consenso de ftr en el genoma de $B$. diazoefficiens USDA 110 (acotada a 250 bases upstream de cada ORF de los genes del flagelo subpolar) nos permitió encontrar algunas probables cajas promotoras conservadas delante de varios genes relacionados con el flagelo subpolar (Figura V.3).

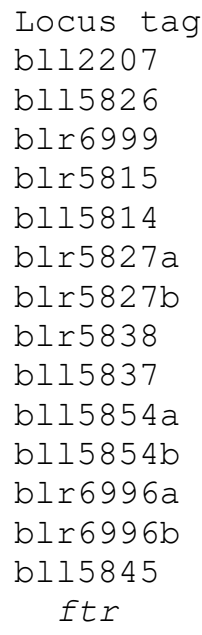

$\mathrm{CB}$

$\mathrm{CB}$

$\mathrm{CB}$

SS

$B$

$B$
F

Figura V.3 - Alineamiento de regiones promotoras de genes del flagelo subpolar de $B$. diazoefficiens USDA 110 que contienen secuencias ftr putativas. En gris se marcaron las bases de la secuencia consenso $f t r$. A la derecha de cada secuencia se encuentra representada la estructura de la que forma parte la proteína que codifica ese gen, CB: cuerpo basal, SS: SSTIII, B: bastón, R: regulador, G: gancho, F: filamento. Las letras a y $b$ indican más de una secuencia ftr encontrada. ATG representa el codón de inicio de la traducción y entre paréntesis la distancia del mismo a la caja ftr, en número de bases.

Esta observación in silico apoyó la idea de que el par regulador FlbD-FliX podría ser el responsable del control del sistema del flagelo subpolar en $B$. diazoefficiens USDA 110. Para abordar su estudio, y el rol sobre la cascada de señalización de la síntesis del flagelo subpolar en esta especie, comenzamos construyendo mutantes de los genes que codifican FlbD y FliX y la posterior caracterización fenotípica de los mismos.

\section{V.3 Construcción de mutantes de B. diazoefficiens en $f l b D$ y $f l i X$}

Para mutagenizar flbD (blr7003), se diseñó una estrategia de deleción de un fragmento interno del gen por doble recombinación homóloga aprovechando los sitios de restricción Aval presentes en el mismo (Figura V.4). 


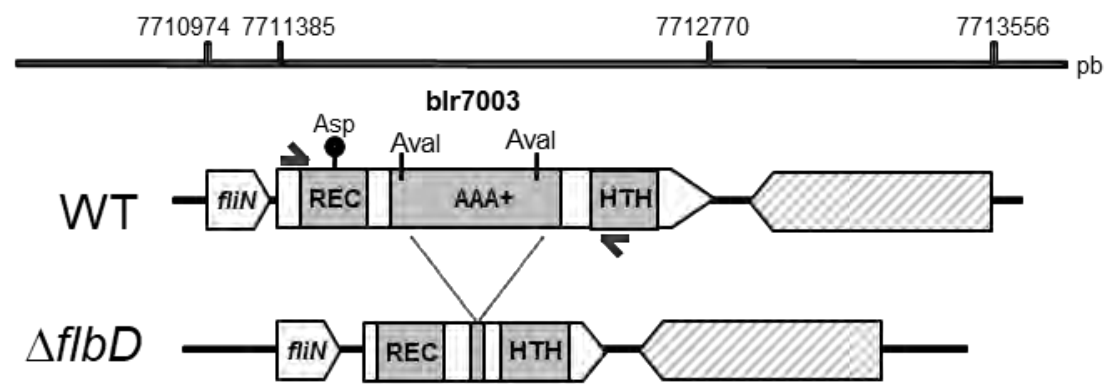

Figura V.4 - Mapa esquemático del gen flbD (blr7003) y genes vecinos (c/uster 6) que muestra el diseño utilizado para su mutagénesis. La estrategia consistió en la amplificación de un fragmento del gen por PCR para luego delecionar un fragmento interno (casi toda la secuencia del dominio AAA+) por digestión con la enzima Aval. Los primers de chequeo de la mutación se muestran con flechas. Los símbolos rayados son genes que no guardan relación con ningún componente flagelar.

Para llevar a cabo esta estrategia de mutagénesis, se amplificó por PCR un fragmento del gen correspondiente a $1.395 \mathrm{pb}$ del genoma de $B$. diazoefficiens USDA 110 (entre las bases 7.711.305 y 7.712.680) utilizando los primers 7003_FwE y 7003_RvH (Tabla II.5). El fragmento se purificó del gel de agarosa y se digirió con las enzimas de restricción EcoRI y HindIII (los sitios de restricción fueron agregados en la secuencia de los primers) y se clonó en el vector pK18mobsacB. Luego se eliminó un fragmento interno de 354 pb comprendido entre los sitios Aval, quitando así la mayor parte de la secuencia codificante del dominio AAA+ de la proteína. Dicha construcción fue introducida por conjugación biparental en $B$. diazoefficiens USDA 110 y se seleccionaron posibles clones mutantes como se indicó en Materiales y Métodos mediante contraselección utilizando el gen sacB (Capítulo II.4.9.b). La deleción fue verificada mediante una reacción de PCR utilizando los primers Ext7003_FwX y Ext7003_RvP, externos a la región clonada inicialmente (Figura V.6 y Tabla II.5). Este producto de amplificación dio un tamaño de $1.297 \mathrm{pb}$, el cual fue corroborado por secuenciación. De esta manera, se obtuvo el mutante delecional "limpio" (sin resistencia a antibiótico y conservando el marco de lectura) al que denominamos $\Delta f l b D$.

Para mutagenizar flix (bll5837), planteamos la inserción de un cassette de resistencia a kanamicina utilizando el sitio BamHI presente a mitad del ORF (Figura V.5). 


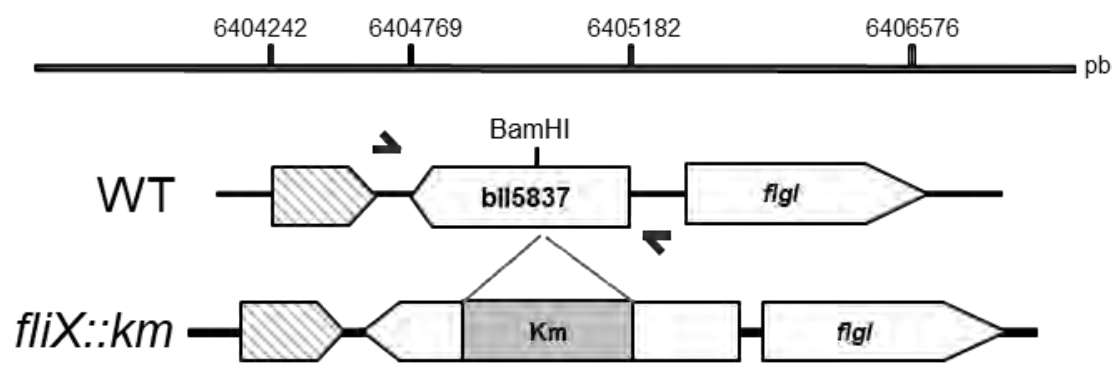

Figura V.5 - Mapa esquemático del gen flix (bll5837) y genes vecinos (cluster 5) que muestra el diseño utilizado para su mutagénesis. La estrategia consistió en amplificar el gen por PCR y clonar en el sitio BamHI que se ubica dentro del gen, un cassette de resistencia a kanamicina $(\mathrm{Km})$. Los primers de chequeo de la mutación se muestran con flechas. Los símbolos rayados son genes que no guardan relación con ningún componente flagelar.

Para comenzar la construcción del mutante, se amplificó por PCR un fragmento de $1.001 \mathrm{pb}$ del genoma de $B$. diazoefficiens USDA 110 (entre las bases 6.404.484 y 6.405.484) utilizando los primers 5837_Fw y 5837_Rv. Este producto se purificó de gel y se clonó con EcoRV, que deja extremos romos, en el vector de entrada pBlueScriptSK(+), obteniendo el plásmido pG::5837 (Figura V.7-A). Se seleccionaron aquellos clones que tuvieran el gen en sentido del plac para un posterior subclonado. El plásmido así construido se digirió con EcoRI-HindIII, el fragmento liberado se clonó en pG18mob2 y luego, aprovechando el sitio BamHI que se encuentra dentro del gen, se clonó el cassette de resistencia a kanamicina (1.264 pb) proveniente del plásmido pUC4K, generando el plásmido pG::5837::Km (Figura V.7-C). Los recombinantes dobles fueron obtenidos como se describe en Materiales y Métodos (Capítulo II.4.9-a). Los clones mutantes se verificaron mediante reacciones de PCR que amplificaron ambos extremos del gen hasta el cassette $\mathrm{Km}$ utilizando los pares de primers Ext5837_Fw y Km_Fw (1.000 pb) y Ext5837_Rv y Km_Rv (1.172 pb) y se corroboraron ambos por secuenciación. La Figura V.8 muestra un esquema de los pasos de este proceso de clonado. Al mutante obtenido lo llamamos flix::Km.

Este mismo procedimiento también se realizó sobre el mutante $\Delta f l b D$, de manera que se obtuvo el mutante doble en ambos genes reguladores, denominado $\triangle f l b D$ fliX::Km.

Con el objetivo de complementar el mutante $\triangle f \mid b D$, se amplificó el gen completo por PCR con Pfu (1.651 pb) y se clonó en el plásmido pBBR1MCS3 obteniéndose así el plásmido pB3::7003 (Figura V.7). Para complementar el mutante fliX::Km se subclonó el gen fliX desde el plásmido pBS::5837 hacia el plásmido pFAJ1708 con las enzimas Xbal-Kpnl, obteniendo el plásmido pFAJ::5837 (Figura V.9). Estas construcciones fueron chequeadas por PCR con primers externos y por secuenciación y pasadas a sus respectivos mutantes y a la cepa WT por conjugación. Así se obtuvieron las cepas mutantes complementadas, denominadas $\Delta$ flbD-pB3::flbD y fliX::Km-pFAJ::fliX. También se conjugaron dichas cepas con los plásmidos vacíos para utilizarlas como controles, a las cuales denominamos $\Delta f l b D$-pB3 y fliX::Km-pFAJ. 
Los plásmidos vacíos y los plásmidos llevando flbD o flix también fueron introducidos por conjugación biparental a la cepa WT, obteniendo las cepas denominadas $B d$-pB3 y $B d$-pFAJ por $\underline{B}$ radyrhizobium diazoefficiens conteniendo los plásmidos pBBR1MCS $\underline{3}$ y pFAJ1708 y las cepas Bd-pB3::flbD y Bd-pFAJ::flix -por Bradyrhizobium diazoefficiens conteniendo los plásmidos pB3::7003 o pFAJ::5837.

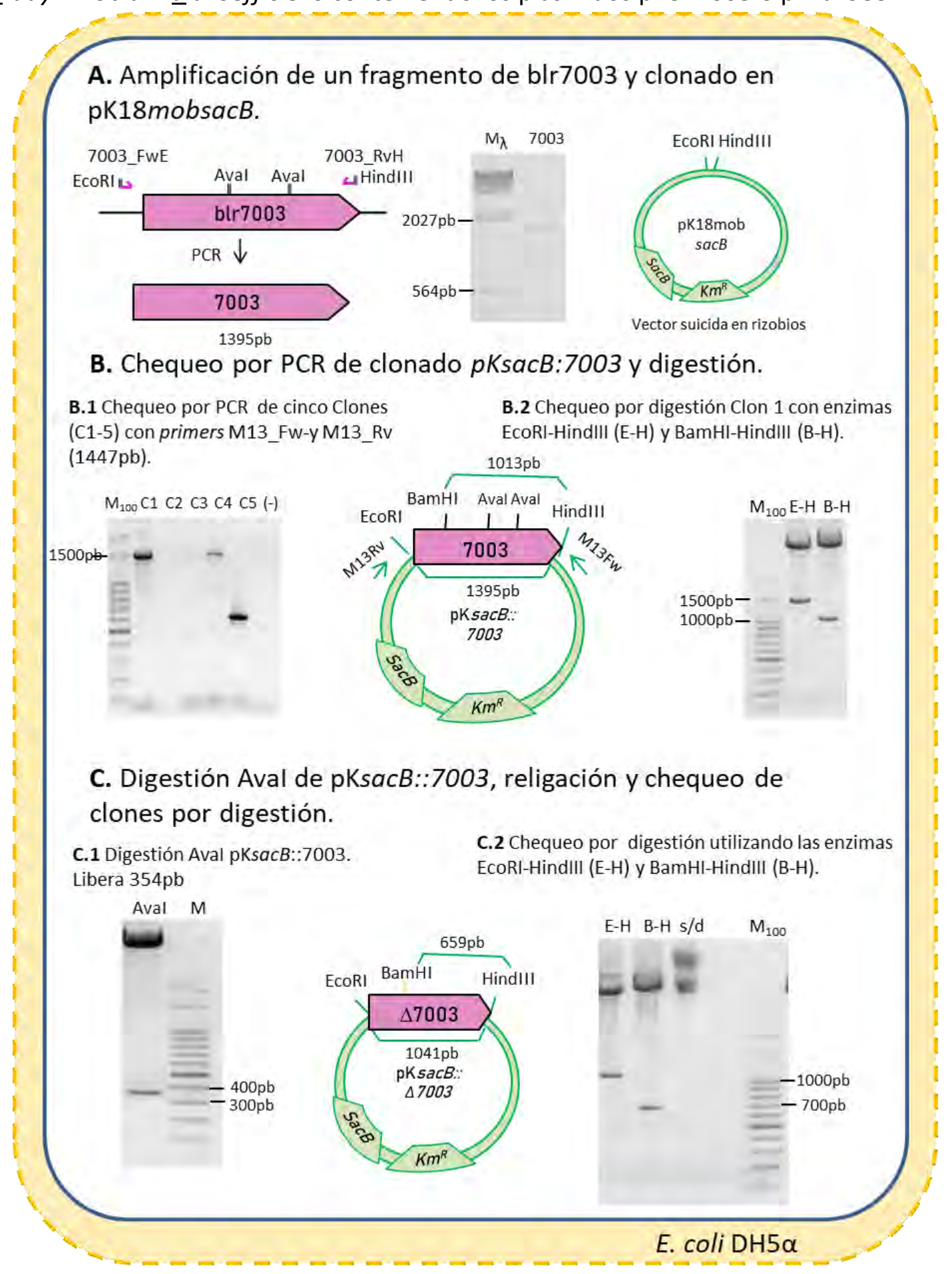




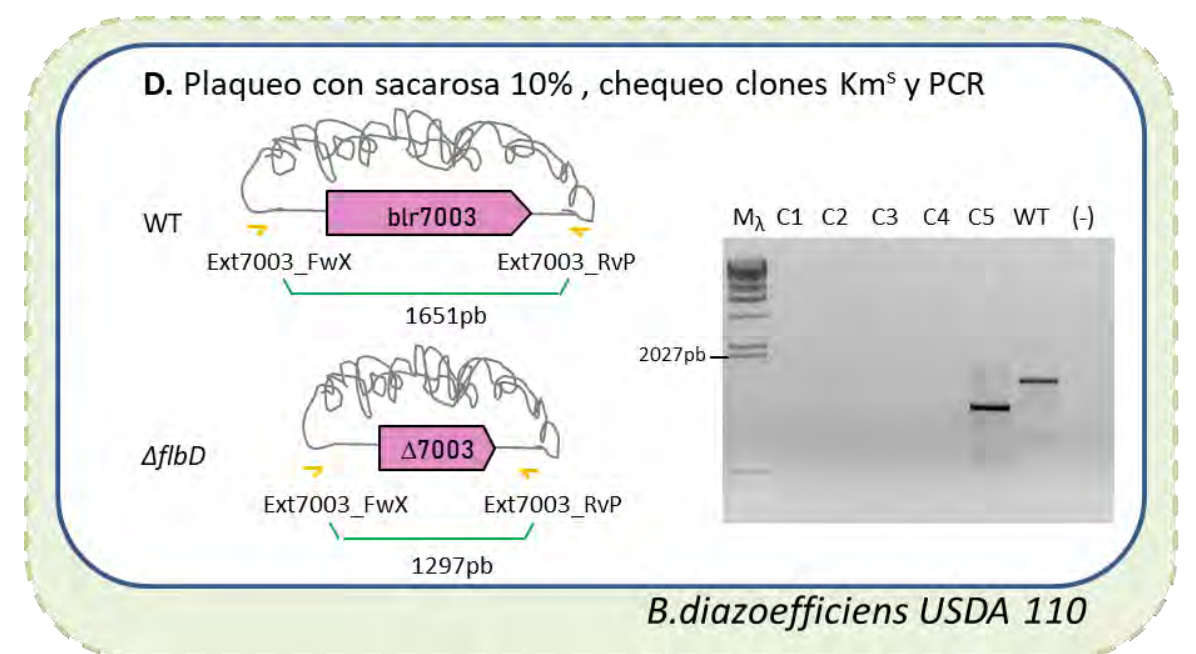

Figura V.6 - Esquema del clonado y selección de la cepa mutante B. diazoefficiens $\triangle f l b D$. El gráfico con el recuadro amarillo representa los pasos de clonado para obtener el plásmido pKsacB:: 7003 en $E$. coli. El gráfico con el recuadro verde muestra un esquema del cromosoma de $B$. diazoefficiens WT y del mutante con énfasis en el gen flbD y su comprobación por PCR (gel de agarosa). 7003 representa el fragmento de blr7003 amplificado. En los geles de agarosa, $M_{100}$ y $M_{\lambda}$ indican los marcadores de peso molecular de $100 \mathrm{pb}$ y $\lambda$-HindIII, respectivamente. Con la letra $\mathrm{C}$ y un número se indican diferentes clones chequeados por PCR durante las construcciones (B y D). WT indica el control con ADN de la cepa WT y (-) el control negativo con agua. En el caso de las digestiones se indican con las iniciales de las enzimas usadas o $\mathrm{s} / \mathrm{d}$ indica el plásmido sin digerir. 
A. Amplificación del gen blr7003 y clonado direccional del mismo en pBBR1MCS3.
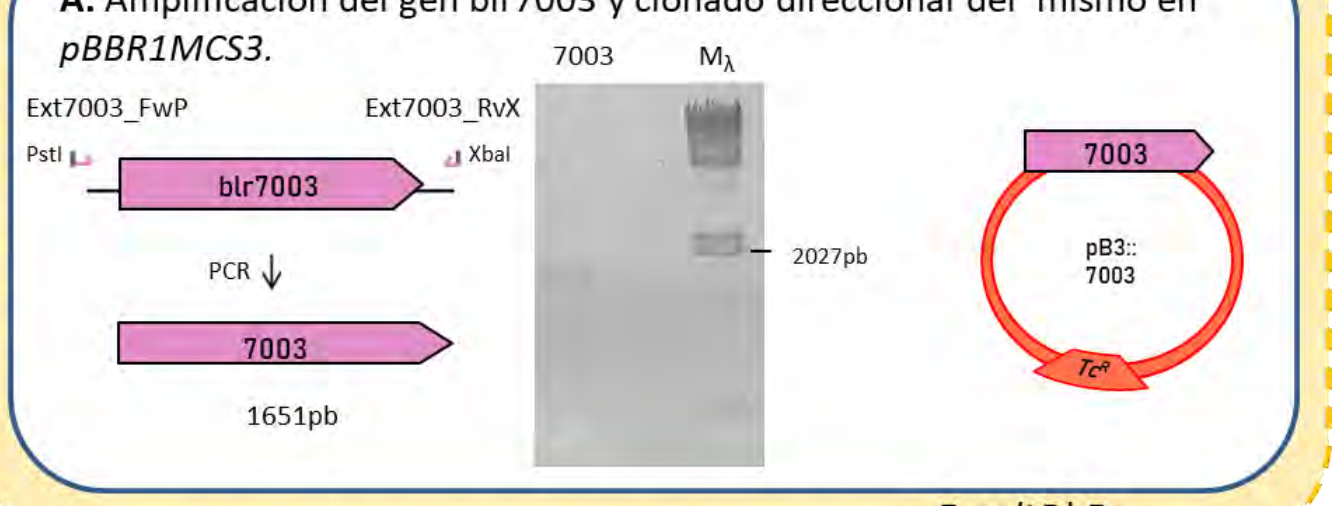

\section{E. coli Dh5 $\alpha$}

B. Chequeo de introducción del plásmido en $B$. diazoefficiens utilizando un primer específico del gen y un primer del vector.

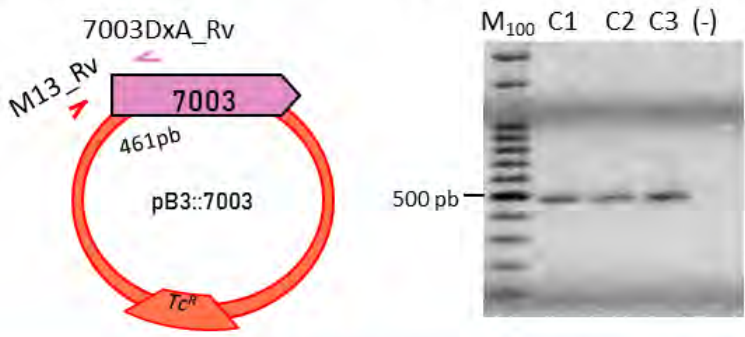

B. diazoefficiens USDA 110 WT o $\triangle$ flbD

Figura V.7 - Esquema del clonado y selección de las cepas WT y $\Delta$ flbD llevando pB3:: flbD. El gráfico con el recuadro amarillo representa los pasos de clonación para obtener el plásmido pB3::7003 en E. coli y el gráfico con el recuadro verde muestra los pasos realizados para obtener las cepas de B. diazoefficiens WT o el mutante $\Delta f \mid b D$ llevando pB3::7003. 7003 representa el fragmento de blr7003 amplificado con los primers externos. En los geles de agarosa, $M_{100}$ y $M_{\lambda}$, indican los marcadores de peso molecular de $100 \mathrm{pb}$ o $\lambda$-HindIII respectivamente. Con la letra $\mathrm{C}$ y un número se indican diferentes clones chequeados por PCR durante las construcciones (B). (-) indica el control negativo de PCR con agua. 
A. Amplificación del fragmento de bll5837 con extremos romos y clonado en el vector de entrada pBlueScriptSK(+) digerido EcoRV.
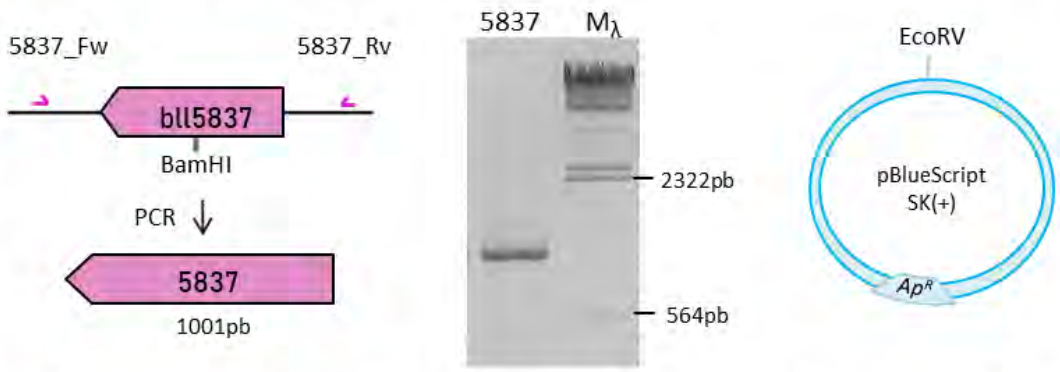

B. Chequeo por digestión pBS::5837 utilizando la enzima BamHI y subclonado a pG18mob2 en los sitios EcoRI-HindIII.
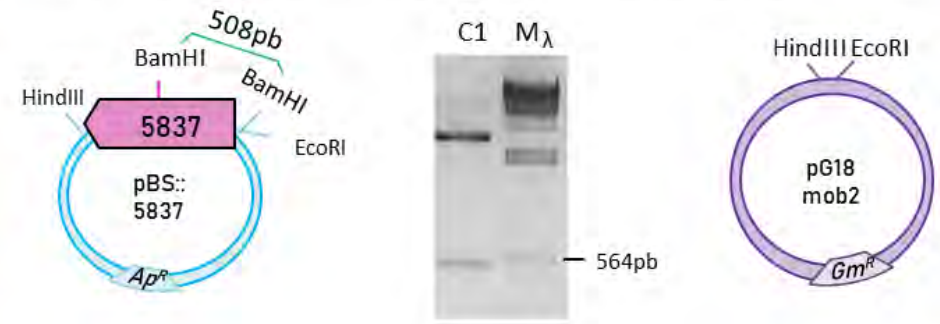

C. Inserción cassette de Kanamicina en el sitio BamHl y chequeo por digestión Xhol-EcoRI.
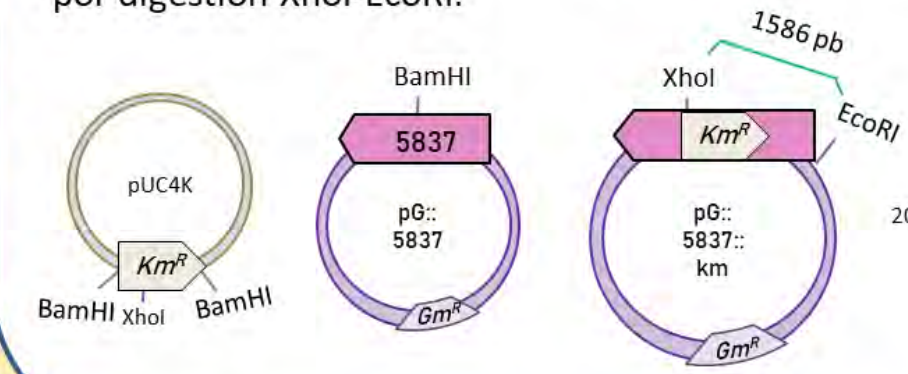

E. coli $\mathrm{DH} 5 \alpha$ 
D. Selección de recombinantes dobles (colonias $\mathrm{Km}^{\mathrm{R}}$ ) y chequeos por PCR con primers externos.

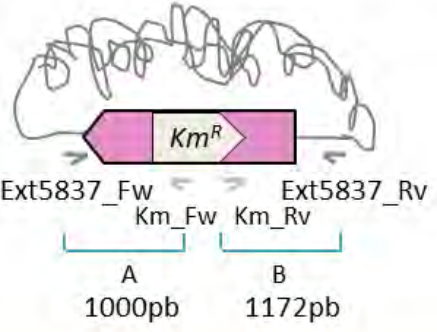

A $M_{100} \quad B$

$1500 \mathrm{pb}$

$1000 \mathrm{pb}$

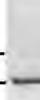

B. diazoefficiens USDA 110

Figura V.8 - Esquema del clonado y selección de la cepa mutante $B$. diazoefficiens flix::Km. El gráfico con el recuadro amarillo representa los pasos de clonado para obtener el plásmido pG::5837::Km en E. coli. El gráfico con el recuadro verde muestra un esquema del cromosoma de $B$. diazoefficiens mutante con énfasis en el gen flix y su comprobación por PCR (gel de agarosa). 5837 representa el fragmento de bll5837 amplificado. En los geles de agarosa, $M_{100}$ y $M_{\lambda}$ representan marcadores de peso molecular de $100 \mathrm{pb}$ y $\lambda$-HindIII, respectivamente. Con la letra $C$ y un número se indican diferentes clones chequeados con enzimas de restricción (B y C). s/d indica el plásmido sin digerir. 
A. Subclonado del gen blr5837 del plásmido $p B S:: 5837$ al pFAJ1708 y chequeo por digestión con enzimas Xbal-BamHI.
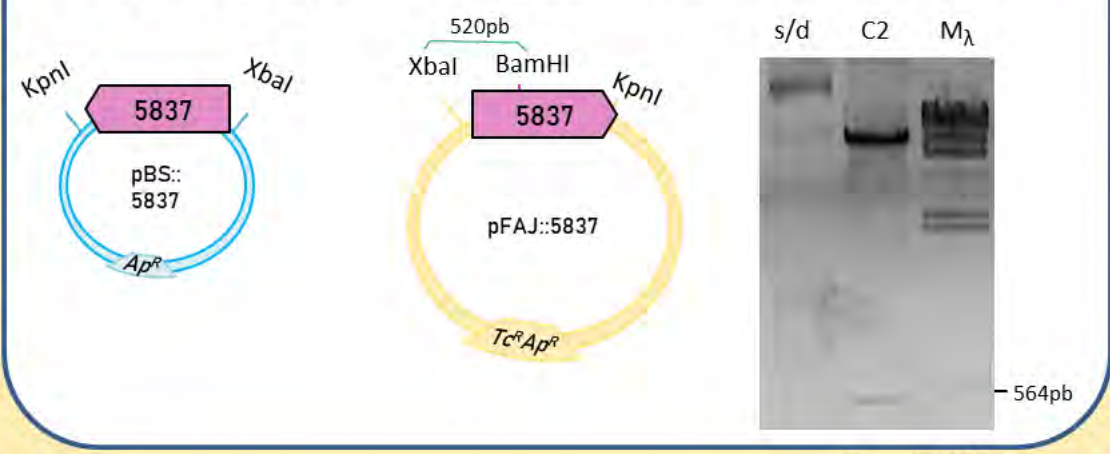

E. coli $\mathrm{DH} 5 \alpha$

B. Chequeo de introducción del plásmido en B. diazoefficiens.
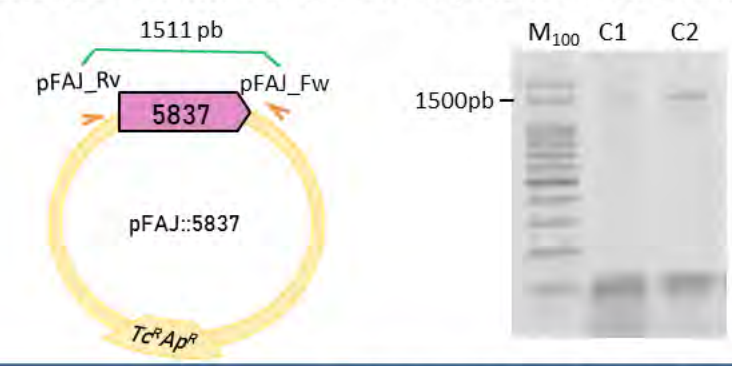

B. diazoefficiens USDA 110 WT o fliX::Km

Figura V.9 - Esquema del clonado y selección de las cepas WT y fliX: Km llevando pFAJ::fliX. El gráfico con el recuadro amarillo representa los pasos de clonación para obtener el plásmido pFAJ::5837 en E. coli y el gráfico con el recuadro verde muestra los pasos realizados para obtener la cepa WT o fliX::Km de B. diazoefficiens llevando pFAJ::5837. En los geles de agarosa, $\mathrm{M}_{100} \mathrm{Y}$ $\mathrm{M}_{\lambda}$ indican los marcadores de peso molecular de $100 \mathrm{pb}$ y $\lambda$-HindllI, respectivamente. Con la letra $\mathrm{C}$ y un número se indican diferentes clones chequeados durante las construcciones, ya sean digestiones con enzimas de restricción (A) o productos de PCR (B).s/d indica el plásmido sin digerir.

\section{V.4 Caracterización fenotípica de los mutantes $B$. diazoefficiens $\Delta$ flbD y fliX::Km}

Para comenzar la caracterización de las cepas mutantes en los posibles reguladores de clase II se procedió en primer lugar a analizar el crecimiento de las mismas. Según la evidencia previa en otras especies bacterianas, el par regulador FlbDFliX podría estar interconectado con la regulación del ciclo celular (Muir et al., 2005). Sin embargo, en $B$. diazoefficiens no observamos diferencias significativas en la velocidad de crecimiento $\mathrm{ni}$ en la máxima $\mathrm{DO}_{500}$ alcanzada en fase estacionaria para ninguno de los mutantes ensayados, en comparación con la cepa WT. La Figura V.10 muestra fotografías tomadas con el microscopio óptico, donde se observa que las cepas WT y mutante no tuvieron diferencias de tamaño ni cambios en su morfología, 
contrariamente a lo observado por Muir y col (2005) en C. crescentus. Por ello, descartamos que FlbD y/o FliX estén relacionadas al control de la división celular en $B$. diazoefficiens.

A

B

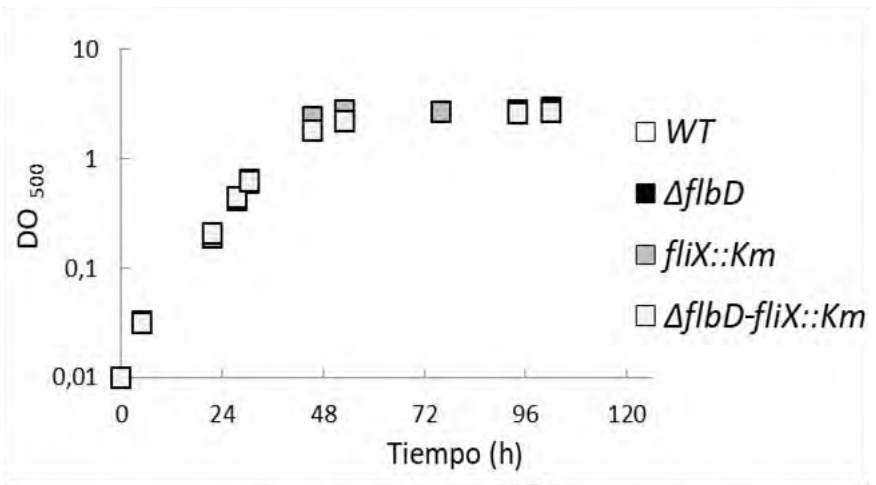

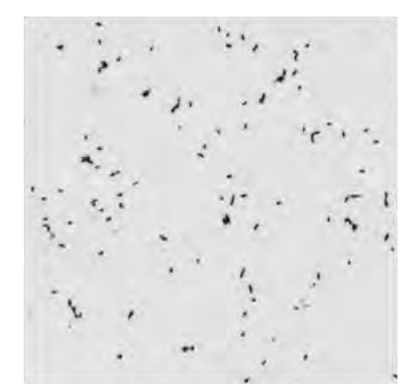

WT

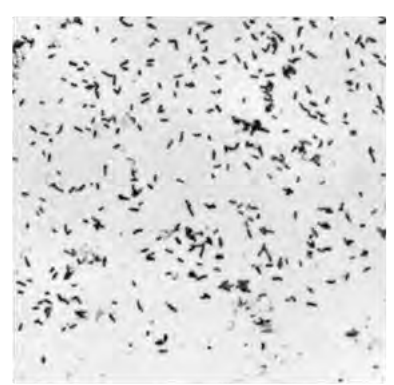

$\triangle f l b D$

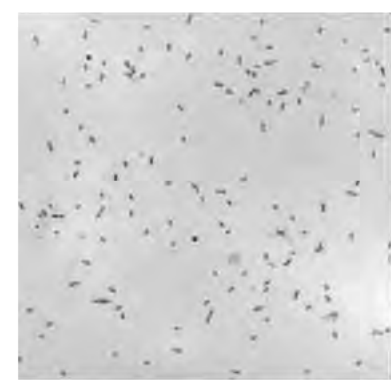

fliX::Km

Figura V.10 - Cinética de crecimiento y morfología celular de las cepas de $B$. diazoefficiens mutantes en flbDy fliX. A. Medida de densidad óptica $\left(\mathrm{DO}_{500}\right)$. en medio líquido $A G$ de la cepa WT y los mutantes en los reguladores de clase II cultivados en medio líquido AG. El gráfico muestra un ensayo representativo de dos réplicas biológicas. El tamaño de las barras de error (desvío estándar) es menor que el de los símbolos. B. Fotos al microscopio óptico (1.000X) de bacterias teñidas con cristal violeta crecidas en medio líquido PSY-ara hasta fase exponencial $\left(\mathrm{DO}_{500}=0,7\right)$.

\section{V.4.1 Efecto de la mutación de $f l b D$ y fliX sobre la síntesis flagelar y la capacidad de natación}

Para continuar con la caracterización de los mutantes, realizamos dos ensayos tendientes a determinar si la ausencia de estos genes afectaban la correcta síntesis flagelar en B. diazoefficiens USDA 110. Así, detectamos que todas las cepas mutantes $(\Delta f l b D, f l i X:: \mathrm{Km}$ y el doble mutante $\Delta f l b D$-fliX::Km) fueron incapaces de sintetizar flagelinas subpolares (FliC, de alto peso molecular) mientras que la síntesis de flagelinas laterales (LafA, de bajo peso molecular) no se vio afectada (Figura V.11-A). 
A

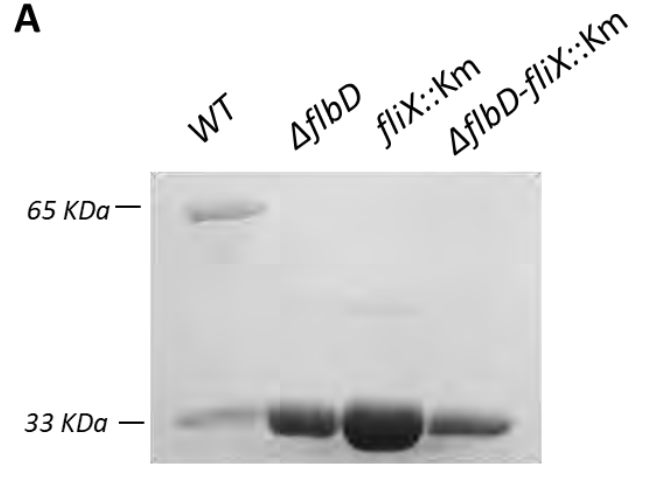

C

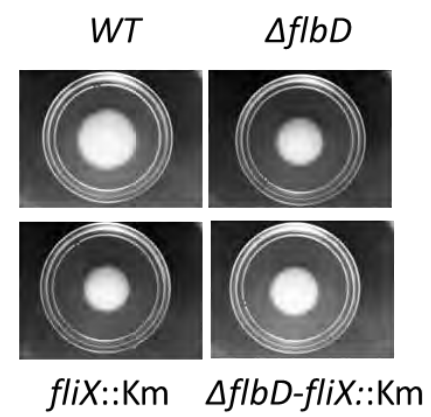

B
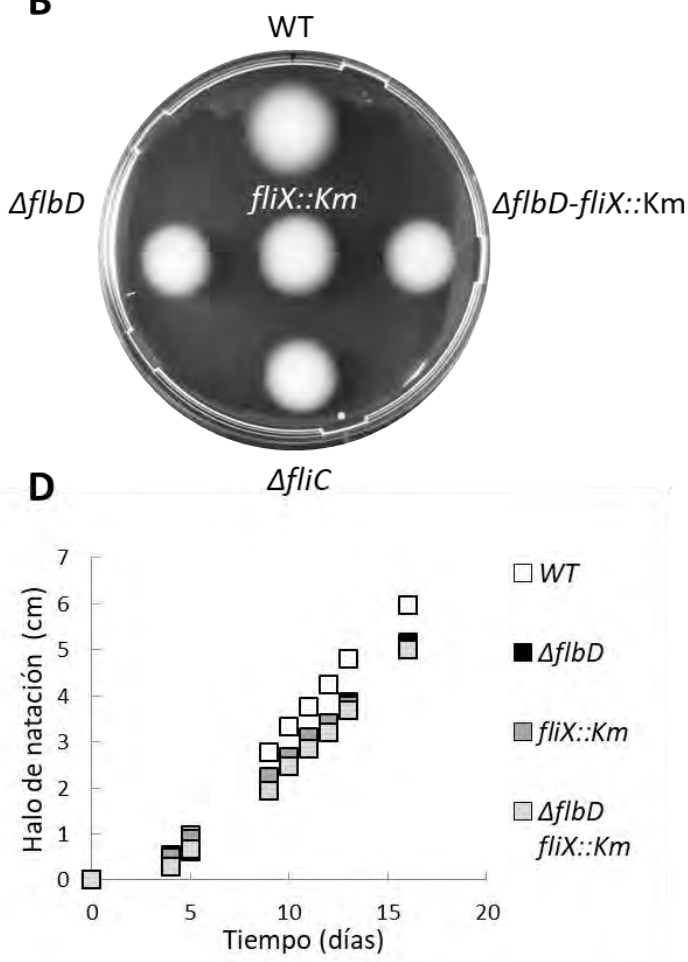

Figura V.11 - Perfil de flagelinas (A) y ensayos de movilidad en agar semisólido (B, C y D) de las cepas de $\boldsymbol{B}$. diazoefficiens mutantes en los reguladores de clase II. A. SDS-PAGE de flagelinas extracelulares $\mathbf{B}$. Foto representativa de un ensayo de natación en agar semisólido de la cepas WT, los mutantes $\Delta f l b D$, flix::Km y $\Delta f l b D-f l i x:: \mathrm{Km}$ y el mutante $\Delta f l i C$ (carente de las cuatro flagelinas subpolares) a los 7 días. C. Ensayo de natación en agar semisólido en placas individuales. Se muestra una foto representativa de cada cepa a los 14 días. $\mathbf{D}$. Los halos de natación de tres réplicas técnicas fueron registrados en función del tiempo y graficados con el desvío estándar (el tamaño de la barra de error es menor que el del símbolo).

Como puede observarse en la Figura V.11, las tres cepas mutantes en los reguladores de clase II (así como el mutante $\Delta f(i C)$, presentaron menor movilidad que la cepa salvaje en placas de agar semisólido (Figura V.11-B). De esta manera, la ausencia de flagelinas subpolares se relacionó directamente con una disminución en la capacidad de natación (Figuras V.11-BCD). Estos experimentos corroboran que el filamento del flagelo subpolar no se forma y que los flagelos laterales serían los únicos funcionalmente activos y los que le confieren capacidad natatoria a los mutantes. Además, las cepas mutantes en los reguladores de clase II presentaron un menor diámetro de halo que la cepa WT, independientemente del tiempo ensayado (Figura V.11-D).

Luego realizamos la complementación de las cepas mutantes expresando los genes salvajes respectivos en trans con el fin de chequear que los fenotipos observados se debieran solo a la inactividad del gen mutado. Como $f l b D$ es el último gen del operón (ver Figura S.2 cluster 6), el fragmento clonado no tendría su promotor nativo. Por ello clonamos flbD (al igual que fliX) en el plásmido pFAJ1708, el cual posee un promotor fuerte llamado pneo (Dombrecht et al., 2001) (Tabla II.2). 
Como muestra la Figura V.12-A, la cepa $\Delta f l b D$-pFAJ::flbD no fue capaz de restituir la síntesis de flagelinas subpolares. Dada la ausencia de complementación, decidimos clonar $f l b D$ en otro plásmido replicativo denominado pBBR1MCS3, donde la transcripción sucedería bajo el control del promotor plac y que también contiene la secuencia Shine-Dalgarno. Esta cepa, denominada $\triangle f l b D$-pB3::flbD tampoco fue capaz de restituir el fenotipo de síntesis de flagelinas (Figura V.12-A) y llamativamente, encontramos que la misma tuvo disminuida su capacidad de natación (Figura V.12-A) comparada con la cepa mutante llevando el plásmido vacío ( $\Delta f l b D$-pB3).

Por otro lado, la mutante fliX::Km llevando el gen salvaje en trans (fliX::KmpFAJ::fliX) sí presentó flagelinas subpolares (Figura V.12-A) y fue capaz de complementar parcialmente el fenotipo de natación con respecto a la cepa mutante que llevaba el plásmido vacío (fliX::Km-pFAJ) (Figura V.12-B).

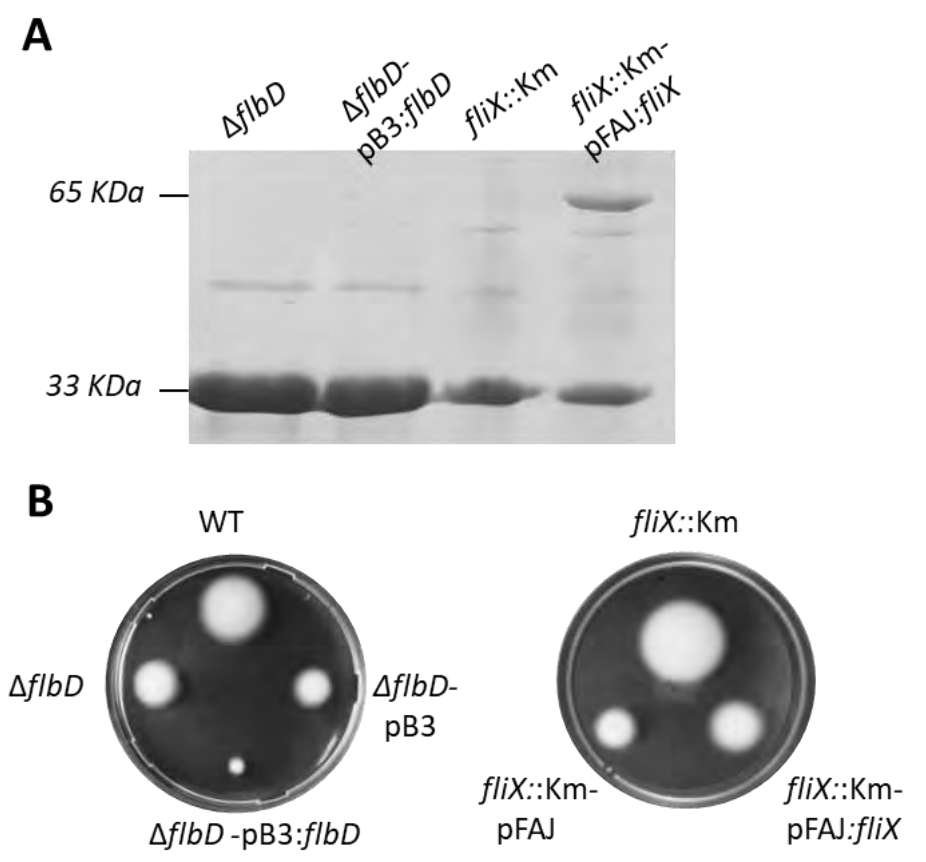

Figura V.12 - Perfil de flagelinas (A) y ensayos de movilidad en agar semisólido (B) de las cepas de $B$. diazoefficiens mutantes en $f l b D$ y flix complementadas. A. SDS-PAGE de flagelinas extracelulares de los mutantes de clase II y las mutantes complementadas. B. Fotos representativas de placas de natación de las cepas mutantes en los reguladores clase $I I$ y las cepas mutantes complementadas a los 7 días (para flbD) y a los 12 días (para fliX).

Dada la imposibilidad de complementar la mutante $\Delta f l b D$, decidimos verificar las mutantes complementadas midiendo los niveles de transcripto del gen clonado en la cepa $\triangle f l b D$-pB3::flbD. Para ello, realizamos un ensayo de RT-PCR y medimos los niveles de $A R N m$ de $f l b D$. Pudimos observar que la cepa $\triangle f l b D-p B 3:: f l b D$ fue capaz de expresar el gen bajo el promotor lac (Figura V.13), a pesar de no sintetizar las flagelinas subpolares (Figura V.12-A). El mutante $\Delta f l b D$, que tiene delecionado un fragmento interno del gen, no mostró señal en la RT-PCR, ya que los primers utilizados hibridan en la región eliminada. Así, la falta de complementación no se debió a una falta de transcripción de la copia del gen clonada en plásmido. 


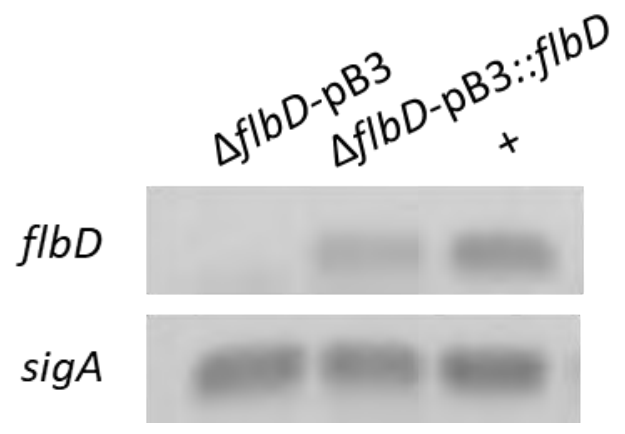

Figura V.13 - Expresión de $f l b D$ en la cepa mutante $\Delta f l b D-p B 3:$ flbD. RT-PCR de la cepa mutante $\Delta f l b D$ que contiene el plásmido vacío $(\Delta f l b D$-pB3) y la cepa complementada $(\Delta f l b D-p B 3:: f l b D)$. Como control interno se utilizó el gen $\operatorname{sigA}$ (que codifica al factor $\sigma^{70}$ ) y se midió el gen flbD utilizando primers que hibridan en la región interna del cDNA del mismo. El signo + representa un control positivo de PCR en el que se usó ADN total de la cepa salvaje como molde.

Es preciso señalar que la deleción del gen $f l b D$ en la mutante $\Delta f l b D$ no es total, y que el mutante "limpio" mantiene el marco de lectura original. Por ello, es probable que la cepa $\triangle f l b D-p B 3:: f l b D$ exprese, además de la proteína FlbD codificada en trans en el plásmido, una proteína "trunca" de 343 aminoácidos, con los dominios REC y HTH completos, la cual podría competir con la copia salvaje por sus genes diana (ya que mantendría el dominio de unión a ADN intacto). Por ello, intentamos restituir el fenotipo en otra cepa mutante en $f l b D$ que construimos, pero que contiene una inserción del cassette de resistencia a $\mathrm{Km}$ (flbD::Km). Así, la cepa flbD::Km pB3::flbD, mostró una banda muy tenue a la altura de las flagelinas subpolares cuando teñimos el gel con plata (Figura V.14-A). De todas maneras, y a pesar de la presencia de lo que creemos son flagelinas subpolares, el halo de natación en placa continuó siendo menor que el de la cepa mutante $f l b D:: K m$ que contiene el plásmido vacío. (Figura V.14-B).

A

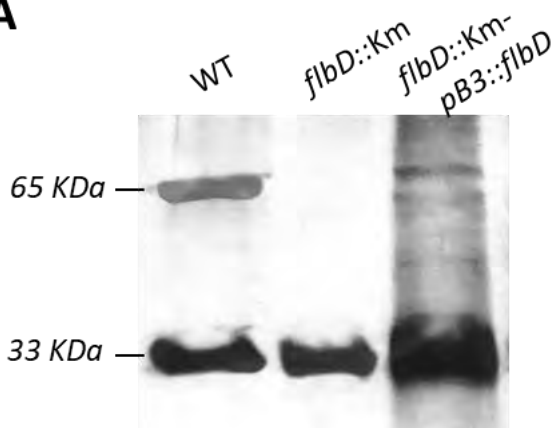

B

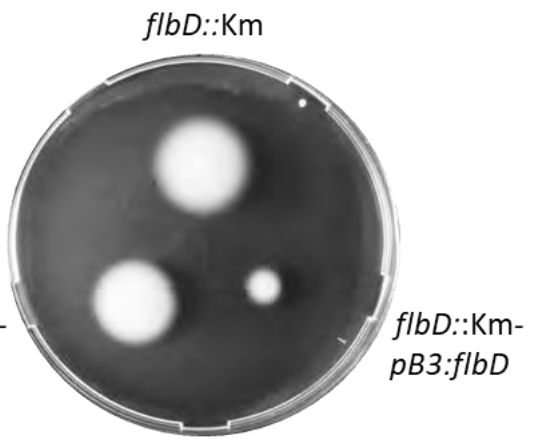

Figura V.14 - Perfil de flagelinas (A) y ensayos de movilidad en agar semisólido (B) de las cepas de $B$. diazoefficiens $f l b D(f l b D:: \mathrm{Km})$ y mutante complementada (flbD:: $\mathrm{Km}$ pB3:: $f(b D)$. A. SDS-PAGE de flagelinas extracelulares. El gel fue teñido con sales de plata para aumentar la sensibilidad. B. Foto representativa de una placa de natación a los 10 días. 
Por otro lado, y dados los resultados previos con las mutantes complementadas, quisimos observar si un exceso de FlbD (a través de una expresión constitutiva en trans) podría afectar la movilidad e impedir que se restituyera la síntesis del flagelo subpolar. Para ello, movilizamos el plásmido pB3::flbD a la cepa WT y analizamos el contenido de flagelinas y la movilidad en medio semisólido. Los resultados se muestran en la Figura V.15. En el caso de la sobreexpresión de flbD encontramos que la cepa WT que lleva el plásmido pB3::flbD presentó una disminución de la cantidad de flagelinas subpolares con respecto a la cepa que contenía el plásmido vacío (Figura V.15-A) y una disminución de su capacidad de natación en agar semisólido (Figura V.15-B). Esto podría indicar que la ausencia de complementación en el mutante $\Delta f l b D$ sería el resultado de una sobreexpresión o expresión en un momento erróneo de este regulador. Llamativamente, la cepa WT que sobreexpresa fliX también presentó una menor capacidad de natación (Figura V.15-B) aunque a diferencia de lo que ocurrió para $f l b D$, la introducción de este mismo plásmido en la cepa fliX::Km sí logró restituir el fenotipo (Figura V.12). Este fenómeno se observó sólo cuando se sobreexpresó fliX en la cepa WT, probablemente por encontrarse en doble copia y regulado bajo su propio promotor además del promotor del plásmido.

A

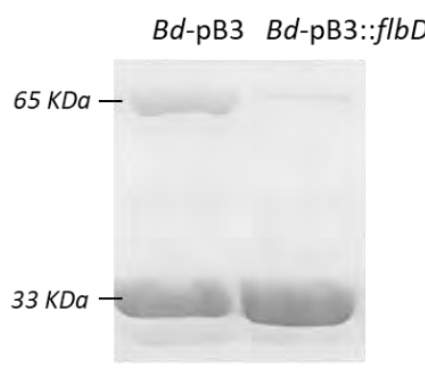

B

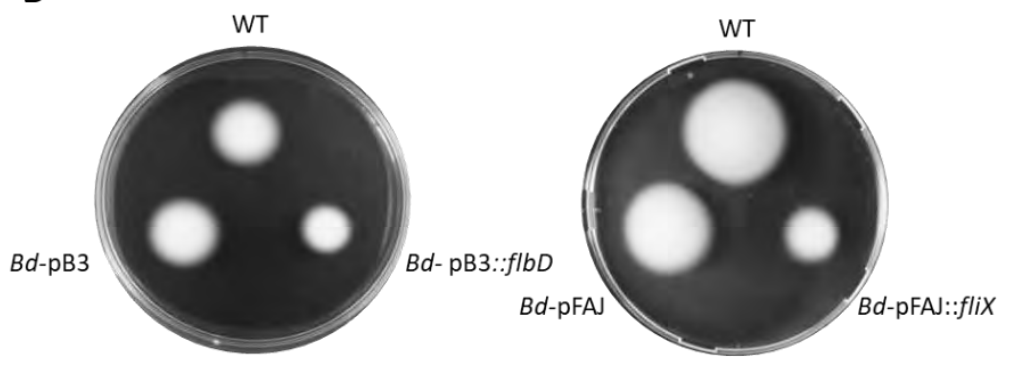

Figura V.15 - Perfil de flagelinas (A) y ensayos de movilidad en agar semisólido (B) de las cepas de $B$. diazoefficiens que sobreexpresan flbD y flix. A. SDS-PAGE de flagelinas extracelulares. B. Placas de natación de las cepas WT que sobreexpresan los reguladores de clase II.

\section{V.4.2 Caracterización de los genes flagelares regulados por FlbD y FliX}

Para confirmar la acción de FlbD sobre la transcripción de genes del sistema del flagelo subpolar y determinar qué estructuras están reguladas por esta proteína, realizamos ensayos de PCR cuantitativa en tiempo real (qRT-PCR). Para ello, diseñamos primers para amplificar distintos genes del sistema del flagelo subpolar (con especial cuidado que no hibriden en sus homólogos del sistema de los flagelos laterales). Como criterio principal, decidimos medir los niveles de transcripto de genes que forman parte de cada una de las subestructuras que constituyen este flagelo (Figura S.1). Además, utilizando herramientas bioinformáticas e información de ensayos de secuenciamiento de ARNm (RNAseq) previos (Cuklina et al., 2016), medimos aquellos 
genes que se encontraban al inicio de cada operón que codifica las estructuras del flagelo subpolar (Figura S.2). Asumiendo entonces que los genes corriente abajo estarían sometidos a la misma regulación que los genes medidos, tendríamos un panorama general de qué ocurriría con la síntesis del flagelo subpolar en esta cepa mutante.

Así, comparamos los niveles de transcriptos de la cepa $\Delta f l b D$, la cual normalizamos con los transcriptos de la cepa WT, y obtuvimos las medidas que se muestran en la Tabla V.1. Cada foldchange representa cuántas veces aumenta o disminuye la expresión de un mismo transcripto en la cepa mutante comparado con la cepa WT. Este valor fue obtenido mediante el método conocido como $\Delta \Delta \mathrm{C}_{\mathrm{T}}$, el cual se encuentra detallado en Materiales y Métodos (Capítulo II.4.4).

Como podemos observar en la Tabla V.1, los niveles de transcripto de los genes flgF, flgE5 y flik en la cepa que carece de FlbD se encuentran muy por debajo del nivel de la cepa WT. Estos resultados nos indican que FlbD presentaría un efecto marcado sobre la transcripción de los genes que codifican la porción distal del bastón y el gancho del flagelo. Cabe destacar que esto mismo no ocurrió con los genes del gancho que se encuentran duplicados en el cluster 3 (que ya han sido analizados en el Capítulo III).

Por otro lado, solo observamos regulación negativa de FlbD sobre flil (ATPasa del SSTIII) entre todos los genes clase II que hemos medido y que creemos que estarían regulados por CtrA. En contraposición, encontramos que el nivel de transcripto de flif, (anillo MS) fue regulado positivamente por FlbD. Este dato fue muy llamativo, dado que el anillo MS es una de las primeras estructuras en ser sintetizadas y ensambladas.

Además, de las cuatro flagelinas que forman el filamento del flagelo subpolar (Althabegoiti et al., 2008; 2011; Quelas et al., 2016a), tres de sus transcriptos (flic234) se encontraron regulados por $\mathrm{FlbD}$, mientras que la regulación de fliC1 no respondió a los niveles de esta proteína. Algo similar ocurre en C. crescentus (Ardissone y Viollier, 2015), donde CtrA regula la transcripción de algunas copias de flagelinas mientras que FlbD o el regulador de clase II, regula la transcripción de otras.

Cabe destacar que a pesar de la ausencia de FlbD, los niveles de transcripto de genes que codifican los reguladores que actúan primero en la cascada regulatoria (CtrA-CckA), como también los de FliX, y de los reguladores posteriores (FlaF y FlbT) no se vieron afectados en la mutante $\Delta f l b D$.

Por otro lado, a pesar de que FliX no sería un regulador transcripcional en sí mismo, su ausencia provoca un fenotipo similar al mutante $\Delta f l b D$. Para evaluar si este co-regulador generaba un defecto en la transcripción de los genes del flagelo subpolar, decidimos medir aquellos que estaban fuertemente regulados por FlbD $\left(f l g F, f l g E_{5}\right.$ y flik) en la mutante flix::Km. Los resultados se muestran en la Tabla V.1. Por un lado, encontramos que los niveles de ARNm de todos ellos efectivamente estuvieron afectados negativamente. Por ello, suponemos que FliX es necesario para que FlbD sea funcional. 
Sin embargo, esta dependencia no se visualizó en aquellos genes donde la regulación mediante FlbD es más sutil, donde no observamos diferencias significativas en el mutante en fliX con respecto a la WT (Tabla V.1). Esto podría indicar que esa regulación fina sería independiente de FliX.

Tabla V.1 Niveles de expresión de ARNm en los reguladores de clase II.

\begin{tabular}{|c|c|c|c|c|}
\hline Función & locus_tag & Gen & $\begin{array}{c}\text { Foldchange } \\
\Delta \text { flbD/WT }\end{array}$ & $\begin{array}{l}\text { Foldchange } \\
\text { fliX::Km/WT }\end{array}$ \\
\hline \multirow{6}{*}{$\begin{array}{l}\text { Genes } \\
\text { regulatorios }\end{array}$} & bll2200 & ctrA & SC & - \\
\hline & blr7003 & $f l b D$ & - & - \\
\hline & bll5837 & flix & SC & - \\
\hline & bll5842 & flaF $_{S}$ & SC & - \\
\hline & blr5847 & $f l b T_{s}$ & SC & - \\
\hline & bll5808 & cckA & SC & - \\
\hline \multirow{3}{*}{ SSTIII } & blr2201 & flil & $2,29 \pm 0,08$ & SC \\
\hline & bll2207 & flhA & SC & SC \\
\hline & blr5816 & fliP & SC & SC \\
\hline \multirow{4}{*}{$\begin{array}{l}\text { Anillos y } \\
\text { motor }\end{array}$} & bll5826 & fliL & SC & SC \\
\hline & blr5838 & $f l g l$ & SC & SC \\
\hline & blr6999 & fliF & $-3,08 \pm 0,07$ & SC \\
\hline & blr3800 & pomA & SC & $\mathrm{SC}$ \\
\hline \multirow{2}{*}{ Bastón } & blr5827 & $f l g F$ & $-55 \pm 38$ & $-13,8 \pm 0,3$ \\
\hline & bll5814 & $f \lg B$ & SC & SC \\
\hline \multirow{4}{*}{ Gancho } & blr3696 & fliD & SC & - \\
\hline & blr3699 & $\mathrm{flg}_{3}$ & SC & - \\
\hline & bll5854 & $f \lg E_{5}$ & $-36 \pm 20$ & $-31 \pm 13$ \\
\hline & blr6996 & flik & $-41 \pm 6$ & $-55 \pm 30$ \\
\hline \multirow{4}{*}{ Filamento } & bll5843 & flic1 & $\mathrm{SC}$ & - \\
\hline & bll5844 & flic2 & $-3,3 \pm 0,6$ & - \\
\hline & bll5845 & flic3 & $-5 \pm 2$ & - \\
\hline & bll5846 & flic4 & $-2,28 \pm 0,08$ & - \\
\hline
\end{tabular}

SC indica que no se detectaron cambios de los niveles de transcriptos.

\section{V.4.3 Mecanismos de acción de FlbD}

Mutación puntual para sustituir el aminoácido aspártico conservado por alanina (D52A)

Como mencionamos anteriormente, FlbD posee un dominio regulador de respuesta que, producto de una correcta progresión del ciclo celular, sería fosforilado y de esta manera activaría la proteína. Si bien este dominio REC presente en FlbD posee conservado el residuo de aspartato susceptible de fosforilación (D54 en NtrC/D52 en FlbD) tanto en C. crescentus como en B. diazoefficiens (Figura V.1), hasta el momento 
no ha sido posible identificar una quinasa responsable de la fosforilación y consecuente activación de esta proteína.

Para comprobar si FlbD necesitaba ser fosforilada en D52 para ser activa y promover la formación del bastón distal y del gancho en $B$. diazoefficiens, decidimos realizar un mutante puntual en donde dicho residuo es reemplazado por un aminoácido no fosforilable (alanina). Para ello, realizamos una estrategia de mutagénesis por doble recombinación homóloga en donde reemplazamos la adenina de la posición 2 del codón 52, que codifica aspartato (GAC) por citosina (GCC), generando así un codón que codifica alanina. Este cambio se realizó diseñando dos pares de primers complementarios, cuya secuencia incluye el cambio puntual (7003DxA_Fw y 7003DxA_Rv). Ver Figura V.16.

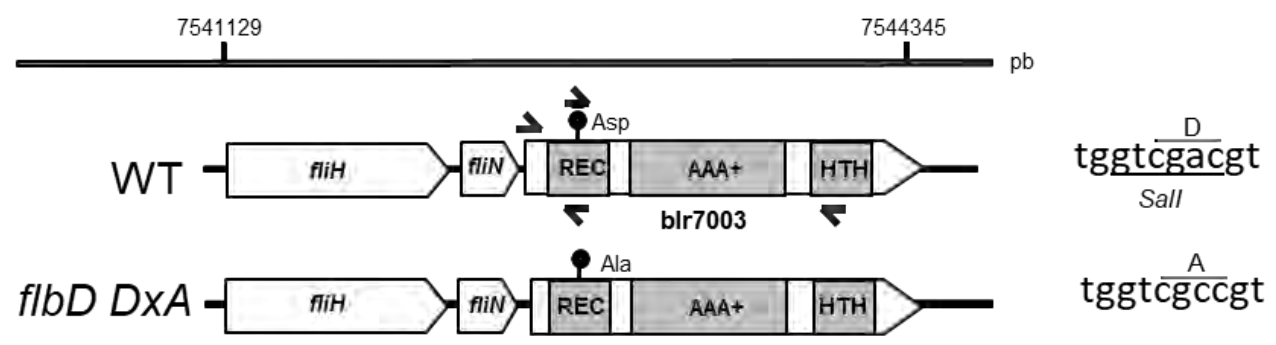

Figura V.16 - Mapa esquemático del gen blr7003 y genes vecinos (c/uster 6) que muestra el diseño utilizado para la mutagénesis puntual para obtener la cepa flbD-DxA. La estrategia de mutagénesis constó de la sustitución de una única base (A por C) para conseguir cambiar el codón que codifica aspartato (GAC) por otro que codifique alanina (G드). El sitio de restricción Sall utilizado para el chequeo, se encuentra subrayado a la derecha de la imagen, perdiéndose al hacer el cambio puntual.

Para realizar la construcción del vector conteniendo $f l b D$ con el cambio puntual, se realizó una primer PCR con los primers 7003_FwE y 7003DxA_Rv amplificando el segmento $5^{\prime}$ del gen $f l b D$ de 238 pb (Up), y otra PCR amplificando el segmento $3^{\prime}$ del gen $(D w)$ de 1.175 pb con los primers 7003DxA_Fw y 7003_RvH (Figura V.17-A). Luego se realizó una tercer PCR con los primers externos 7003_FwE y 7003_RvH usando como molde los dos fragmentos amplificados anteriormente, obteniendo el fragmento 7003DxA (estrategia tomada de Sukdeo y Charles, 2003; ver Materiales y Métodos). De esta manera obtuvimos un fragmento de 1.395 pb que se digirió con las enzimas de restricción EcoRI y HindllI y se clonó en el vector pK18mobsacB (Figura V.17-B). Así, obtuvimos el plásmido pKsacB::7003DxA (Figura V.17-C). El fragmento clonado fue corroborado por secuenciación. Como resultado, se observó que se produjo un cambio adicional en una base río abajo a la zona de mutagénesis. Con el fin de corregir el problema y salvar la construcción, se eliminó la región 3’ del fragmento 7003 (que contiene el cambio no deseado) digiriendo con las enzimas BamHI-HindIII. Luego se rellenaron los extremos $5^{\prime}$ protruyentes con la enzima Klenow y se religaron los extremos del vector. De esta manera se obtuvo el plásmido pKsacB::7003DxA(2) (Figura V.17-D).

Esta construcción fue movilizada por conjugación biparental a B. diazoefficiens USDA 110. Los mutantes fueron chequeados por PCR seguida de digestión del 
fragmento amplificado, y fueron seleccionados aquellos clones cuyos fragmentos 7003 no eran digeridos con la enzima Sall (Figura V.17-F), sitio de restricción que se encontraba en la secuencia del gen WT (gtcgac) y no en la secuencia modificada (gtcgcc). El cambio fue corroborado por secuenciación. A este mutante lo denominamos flbD-DxA.

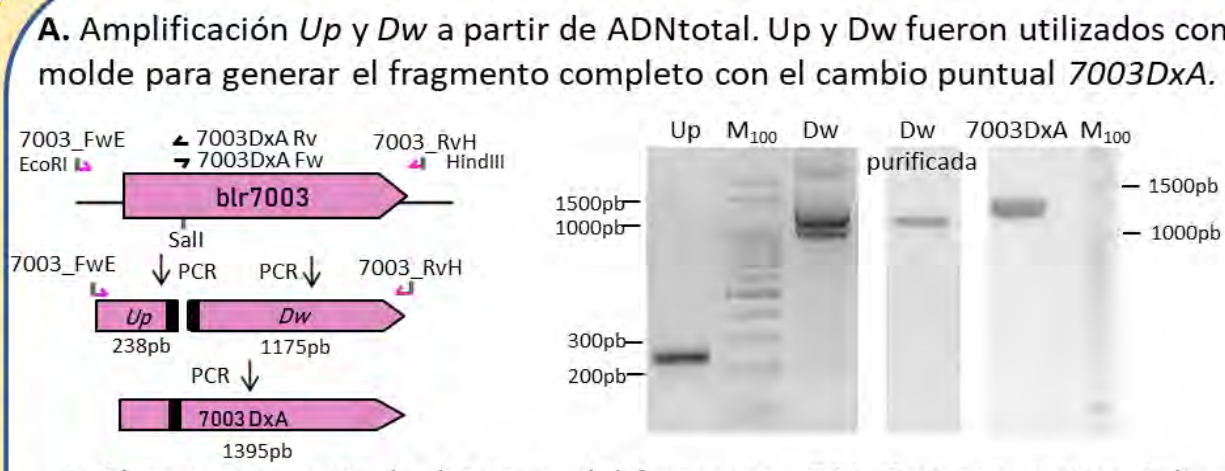

B. Chequeo a través de digestión del fragmento 7003DxA con enzima Sall y clonado en el plásmido pK18mobsacB en los sitios EcoRI-HindIII.

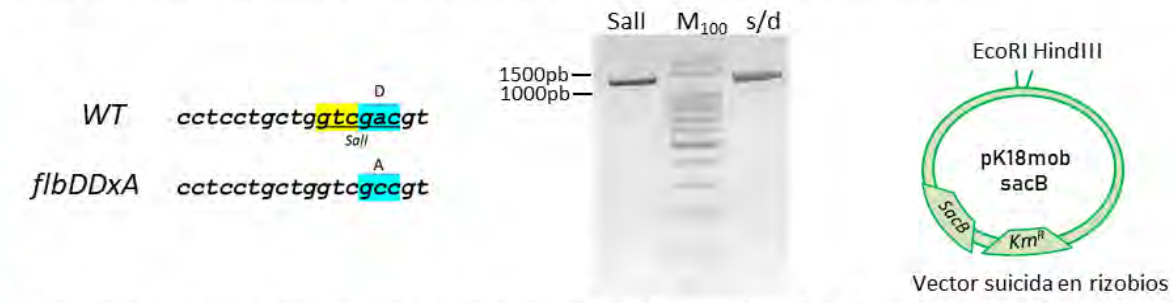

C. Chequeo por digestión con enzimas EcoRI-HindIII de clones $p K s a c B: 7003 D x A$.

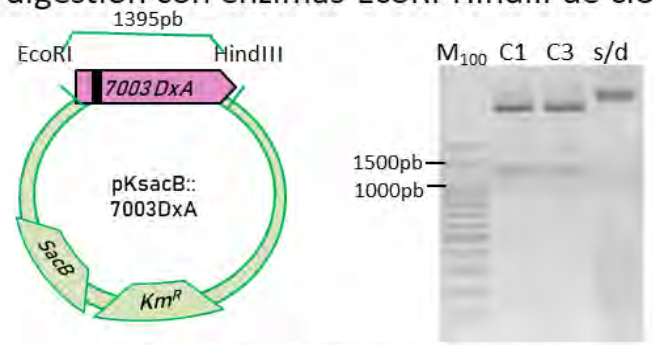

D. Luego de la secuenciación se encontró otro cambio puntual, de manera que se realizó una digestión con enzimas BamHI-HindIII se rellenaron los extremos con la enzima Klenow, se religó y se chequearon clones pKsacB:7003DxA(2) por PCR.

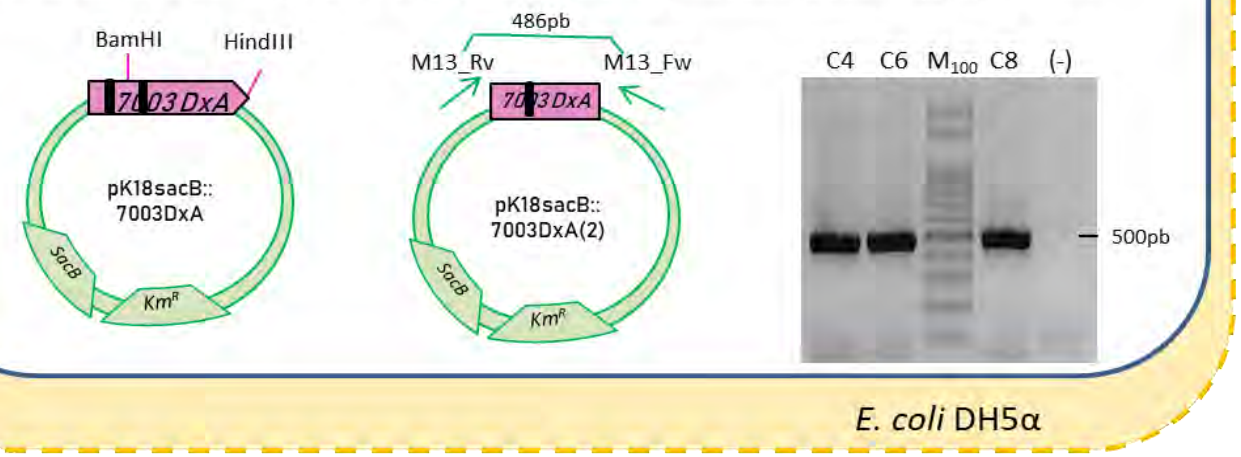




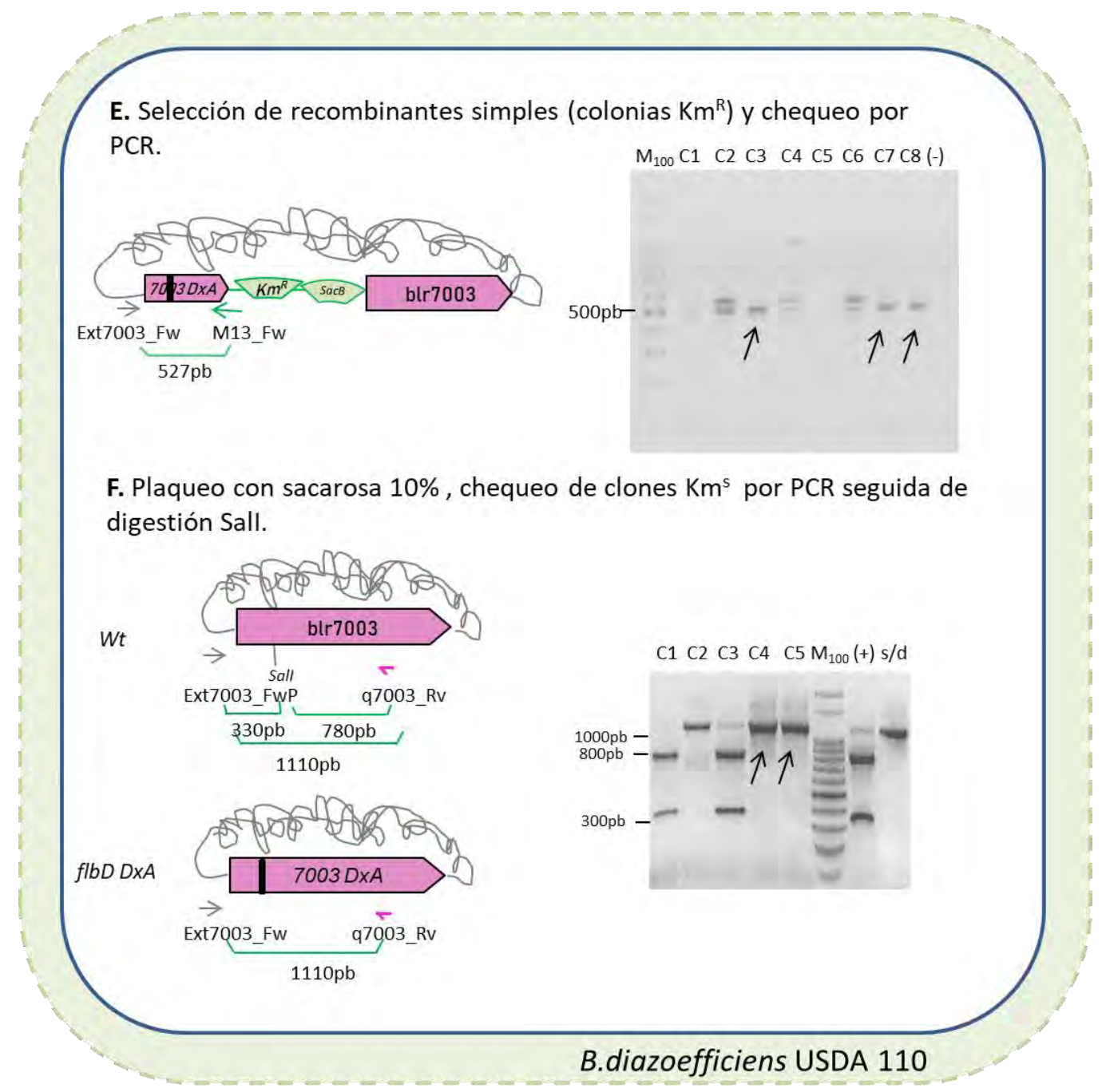

Figura V.17 - Esquema del clonado y selección de la cepa mutante puntual de $B$. diazoefficiens flbDDXA. El gráfico con el recuadro amarillo representa los pasos de clonación para obtener el plásmido pKsacB::7003DxAN en E. coli y el gráfico con el recuadro verde muestra los pasos realizados para obtener el mutante con el cambio puntual (D52A) en el gen blr7003 de B. diazoefficiens. Up y Dw representan la PCR1 y PCR2 de la técnica de Sukdeo y Charles descripta en Materiales y Métodos (Capítulo II.4.9). 7003DxA representa el gen blr7003 conteniendo el cambio puntual en D52A. En los geles de agarosa, $\mathrm{M}_{100}$ indica el marcador de peso molecular de $100 \mathrm{pb}$. Con la letra $\mathrm{C}$ y un número se indican diferentes clones chequeados durante las construcciones, ya sean digestiones con enzimas de restricción (C y F) o productos de PCR (D y E). En todos los casos s/d indica el plásmido sin digerir (C) o la PCR sin digerir (F). El signo (+) en F representa la PCR de la cepa WT digerida.

Una vez construido el mutante puntual flbD-DxA, realizamos los ensayos de obtención de flagelinas extracelulares y natación en agar semisólido para su caracterización. En ninguno de los ensayos observamos diferencias con respecto a la cepa WT (Figura V.18), por lo que suponemos que ese residuo conservado de aspartato no interviene en el control por fosforilación para que la proteína sea funcional en $B$. diazoefficiens USDA 110. 
A

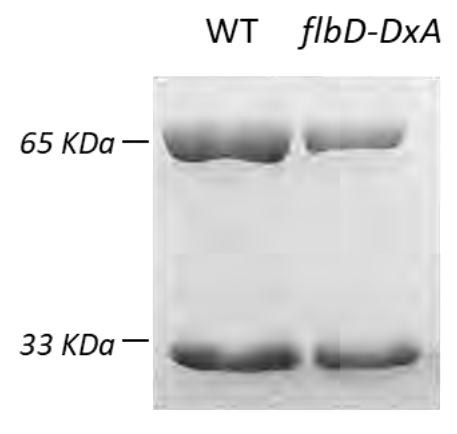

B

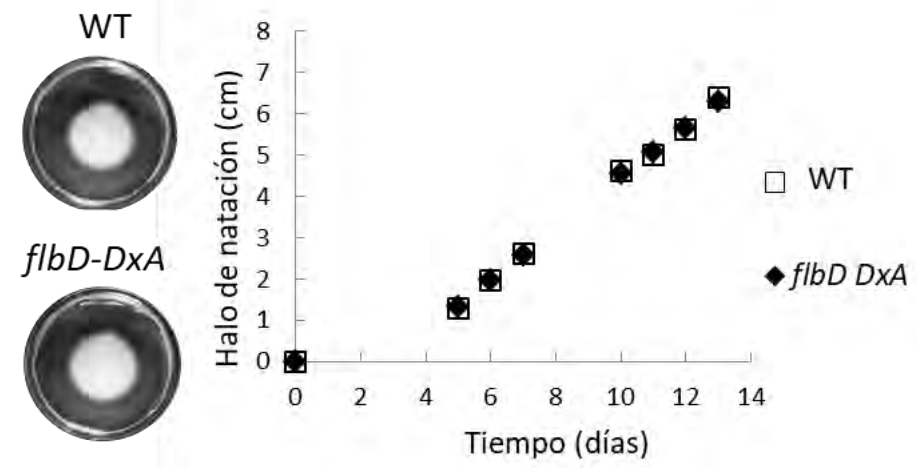

Figura V.18 - Perfil de flagelinas (A) y ensayos de movilidad en agar semisólido (B) de la cepa de $B$. diazoefficiens mutante puntual fIbDDXA. A. SDS-PAGE de flagelinas extracelulares de la cepa WT y el mutante puntual flbDDxA. B. Ensayo de natación en agar semisólido de la cepa WT y flbDDxA. Se muestran fotos representativas de cada cepa en placas de Petri a los 10 días. Los halos de natación de tres réplicas técnicas fueron registrados en función del tiempo y graficados con el desvío estándar. El tamaño de las barras de error es menor al del símbolo.

\section{Factores $\sigma^{54}$ (RpoN)}

En el genoma de $B$. diazoefficiens USDA 110 encontramos dos factores $\sigma^{54}$ que podrían estar mediando la transcripción de los genes $f l b D$ y fliX. Uno de ellos se denomina RpoN1 (BIr1883) y el otro RpoN2 (Blr0723). En estudios anteriores realizados en la cepa B. diazoefficiens USDA 110 spc4 (Kullik et al., 1991) se determinó que ambas proteínas son funcionalmente activas y que las mismas son capaces de reemplazarse entre ellas durante el proceso de simbiosis y de asimilación de nitrato. Para comprobar si ocurría lo mismo con respecto a la síntesis del flagelo subpolar, ensayamos los mismos mutantes generados por Kullik y col. (1991), denominados N50 (mutantes en rpoN1), N63 (mutante en rpoN2) y N50-97 (mutante doble en rpoN1-rpoN2). La extracción de flagelinas extracelulares de estas cepas mostró que el mutante en rpoN2 y el doble mutante en rpoN1-rpoN2 no presentaron flagelinas subpolares, mientras que en el mutante en rpoN1 se observaron ambas bandas, similarmente a la cepa salvaje (Figura V.19-A). Ello nos permitió suponer que FlbD es dependiente de RpoN2 y que, además, RpoN1 no puede complementar la función promotora de RpoN2como sí sucede con otros fenotipos (Kullik et al., 1991).

Para corroborar esta hipótesis, extrajimos el ARN de la cepa WT (en este caso USDA 110-spc4) y la cepa $\Delta r p o N 2$ y realizamos ensayos de RT-PCR. Pudimos observar que efectivamente, los niveles de transcripto de los genes regulados por FlbD (principalmente $f l g F, f l g E_{5}$ y fliK) se encontraban disminuidos en la cepa mutante (Figura V.19-B), en acuerdo con los resultados previos de transcriptómica del doble mutante en rpoN1-rpoN2 (Hauser et al., 2007). Esto nos permitió confirmar que RpoN2 es el responsable de este efecto, y plantear la hipótesis de que este factor $\sigma^{54}$ funciona como un regulador transcripcional del sistema del flagelo subpolar, junto con FlbD y FliX. 
A

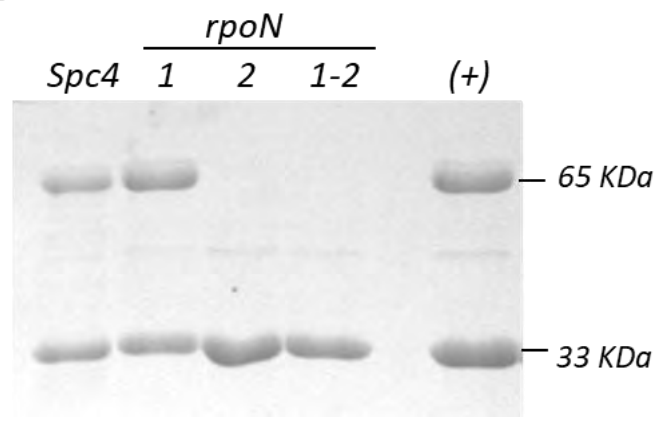

B

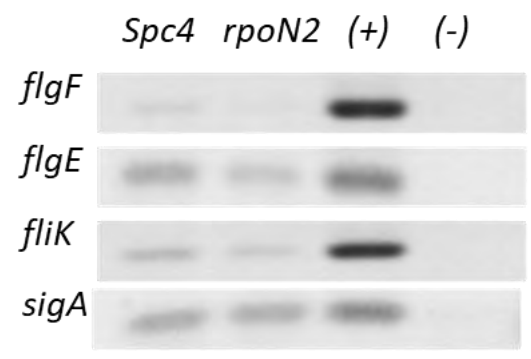

Figura V.19 - Perfil de flagelinas (A) y ensayos de expresión (B) de las mutantes en rpoN1 y/o rpoN2, que codifican factores $\sigma^{54}$ parálogos. A. SDS-PAGE de flagelinas extracelulares. (+) representa la extracción de flagelinas de la cepa USDA 110. B. RT-PCR de los genes $f l g F, f l g E_{5}$ y flik, todos regulados por FlbD, a partir de ARN de la cepa WT (spc4) y del mutante en rpoN2. Como control interno se utilizó el gen sigA, que codifica al factor $\sigma^{70}$. (+) representa el control positivo de la reacción de PCR en el que se utilizó ADN total, y (-) representa el control de PCR en ausencia de ADN molde.

\section{V.4.4 Otros fenotipos asociados con los reguladores clase II FlbD y FliX}

\section{Efecto sobre el sistema flagelar lateral}

Si bien determinamos que los mutantes en flbD y flix no afectaron la correcta síntesis de los flagelos laterales, sí observamos una mayor cantidad de flagelinas laterales, lo que puede apreciarse por la intensidad de la banda correspondiente a LafA en los geles de poliacrilamida (Figura V.11) con respecto a la cepa WT. Para comprobar si la ausencia de FlbD o FliX inducía una mayor expresión del sistema de flagelos laterales, realizamos un ensayo de qRT-PCR con el fin de medir los niveles de transcripto de lafR, que codifica el regulador maestro del sistema lateral (Mongiardini et al., 2017). Así, hallamos que los niveles de ARNm de lafR se encontraron aumentados 9,5 y 2,7 veces en los mutantes $\Delta f l b D$ y fliX::Km, respectivamente, en relación a la cepa WT (Figura V.20). Esto indicaría que la falta del flagelo subpolar funcional, debido a la mutación en cualquiera de los reguladores de clase II (FlbD y/o FliX) tendría un efecto positivo (probablemente compensatorio) sobre la síntesis de los flagelos laterales en $B$. diazoefficiens. 


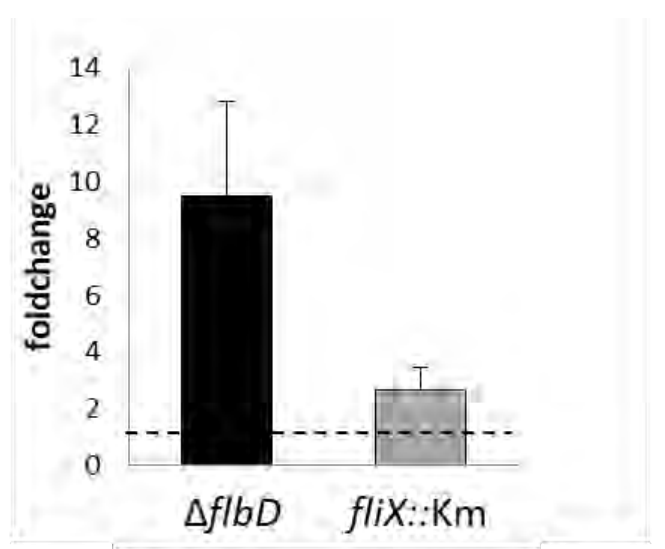

Figura V.20 - Niveles de expresión del transcripto del regulador maestro del flagelo lateral ( lafR) en los mutantes de $B$. diazoefficiens en los reguladores de clase II. Medidas de ARNm del regulador maestro lafR expresada como foldchange de los mutantes $\triangle$ flbD y fliX::Km con respecto a la cepa WT.

\section{V.4.5 Efecto sobre la producción de EPS y la formación de biofilms}

La mutación de $f l b D$ también influyó en otros fenotipos diferentes a los detallados sobre el sistema de flagelo subpolar. Cuando se repicaban las cepas en placa, se observaba que las mutantes eran más mucosas que la cepa WT (Figura V.21-A). Un efecto similar fue descripto con el regulador maestro de $P$. aeruginosa (FleQ), el cual también es una EBP dependiente de $\sigma^{54}$. Baraquet y colaboradores (2012) determinaron que FleQ es capaz de inhibir los genes pel (que codifican proteínas implicadas en la síntesis de EPS) y activarlos cuando aumenta la concentración de c-diGMP. Así, hipotetizamos que FlbD podría estar involucrado en la producción de EPS y de alguna manera vincularía la transición del estado planctónico al de formación de biofilms, de manera similar a lo que ocurre en $P$. aeruginosa.

Para evidenciar el cambio en la producción de EPS realizamos un estudio semi cuantitativo de la capacidad de las macrocolonias bacterianas para unir rojo Congo. Este colorante es capaz de teñir celulosa y algunos polisacáridos, por lo que la capacidad de unir RC nos permite estimar si existe una diferencia en la producción de EPS entre dos cepas. La Figura V.21-A muestra la absorbancia relativa del colorante que no fue capaz de unirse a las bacterias luego de 2 horas de incubación. La mutante $\triangle f l b D$ presentó menor capacidad de unir rojo congo comparado con la cepa WT, mientras que en el mutante fliX::Km no se observaron diferencias significativas (Figura V.21-A).

Para confirmar el efecto de estas mutaciones sobre la síntesis de EPS, realizamos una cuantificación de los mismos a partir de sobrenadantes de cultivos líquidos. Así, logramos evidenciar que la mutante $\triangle f l b D$ sintetizó 2,5 veces más EPS en fase estacionaria comparada con la cepa WT, mientras que la mutante fliX::Km mostró un comportamiento intermedio entre la cepa WT y el mutante $\Delta f l b D$ (Figura V.21-B). 
A

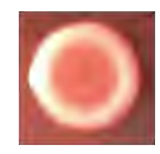

WT

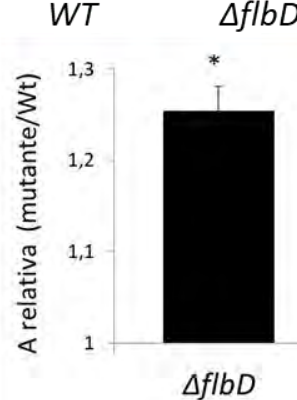

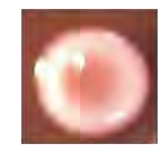
$\triangle f l b D$
fliX::Km

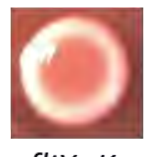

flix:

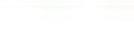

B

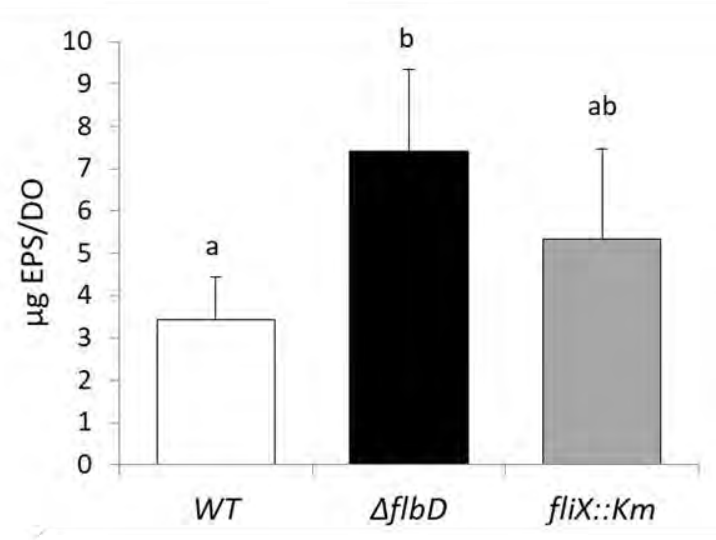

Figura V.21 - Producción de EPS en los mutantes en los reguladores clase II. A. Unión de rojo Congo a los mutantes $\Delta f l b D$ y flix::Km comparados con la cepa WT. El ensayo se repitió en tres oportunidades. Arriba se muestran fotos representativas de las colonias crecidas en placas YEM con rojo Congo. Abajo se muestra la absorbancia relativa del colorante medida a 490nm (Capítulo II.3.10) El asterisco representa diferencias significativas $p=0,05$. B. Cuantificación del EPS producido en fase estacionaria de crecimiento en medio líquido PSY-ara. El análisis estadístico fue realizado sobre tres réplicas biológicas con tres réplicas técnicas utilizando ANOVA con $p=0,05$.

Debido a que la producción de EPS es uno de los factores importantes para la formación de la matriz de los biofilms, nos preguntamos si este proceso también se encontraría afectado en estos mutantes. Ello nos motivó a realizar ensayos de adhesión a tubos de vidrio, en donde observamos que los halos de biofilm de las cepas mutantes $\triangle f l b D$ y fliX:: $\mathrm{Km}$ tardaron más tiempo que la WT en formarse en la interfase aire-líquido (Figura V.22). Sin embargo, este retraso fue momentáneo, ya que ambas cepas mutantes fueron capaces de adherirse y formar biofilm en los tubos de vidrio con el correr del tiempo. Este efecto inicial podría deberse a la falta del flagelo subpolar y su posible rol como adhesina en etapas tempranas de formación de biofilm (Quelas et al., 2016a).

Para comprobar la función de ambos flagelos y su posible rol como adhesinas, realizamos ensayos de adhesión en tubos de vidrio con las cepas $\Delta$ flic (mutante en flagelinas subpolares), $\Delta$ lafA (mutante en flagelinas laterales) y un mutante doble $\Delta$ lafA- $\Delta$ fliC (mutante que no posee flagelos).

Al parecer, el flagelo subpolar sería importante en las primeras etapas de formación de biofilm ya que la cepa carente del flagelo subpolar $\Delta$ fliC se adhirió menos al tubo de vidrio comparada con la cepa WT (Figura V.23). Paralelamente, la cepa que carece de flagelos laterales fue capaz de unirse mejor a la superficie con respecto a la cepa que posee ambos flagelos (WT), por lo que estimamos que los flagelos laterales podrían estar estorbando durante este proceso. Un efecto interesante se observó en la cepa carente de los dos sistemas de flagelos, ya que la misma fue capaz de unirse al vidrio en etapas tempranas. Ello indicaría que la acción del flagelo subpolar es útil para la unión al vidrio aunque no es predominante en este proceso. Además, la mayor capacidad de esta cepa para formar biofilm en etapas tardías podría estar dada por la 
unión irreversible al vidrio ya que, al no tener flagelos, las bacterias no podrían despegarse del soporte y volver como células planctónicas al seno del líquido.

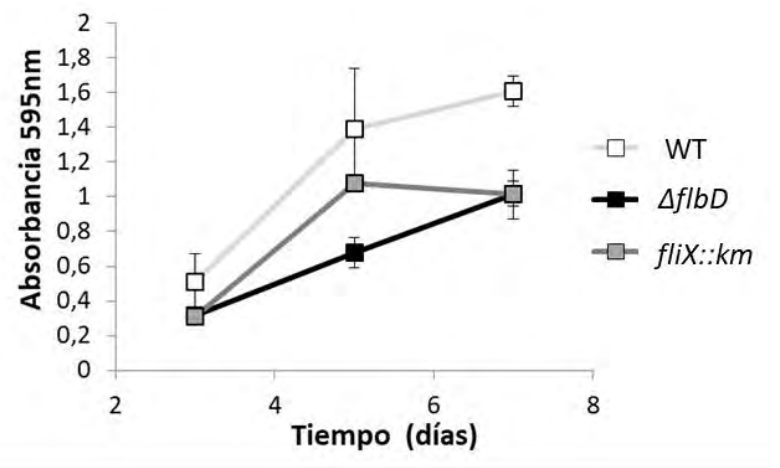

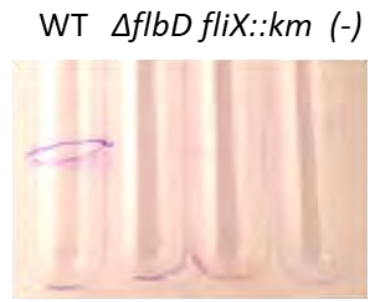

Día 3

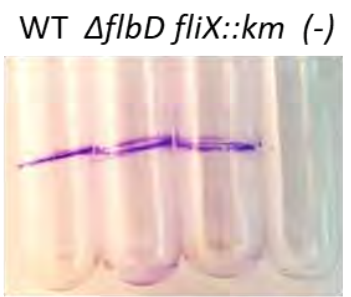

Día 7

Figura V.22 - Adhesión a tubos de vidrio de los mutantes de B. diazoefficiens en los reguladores de clase II. Arriba se grafica una réplica biológica representativa (de tres ensayos) en donde se muestra la absorbancia promedio del cristal violeta adherido. Abajo se muestran fotos representativas del halo de adhesión a los 3 y 7 días. (-) muestra un tubo control sin inocular.
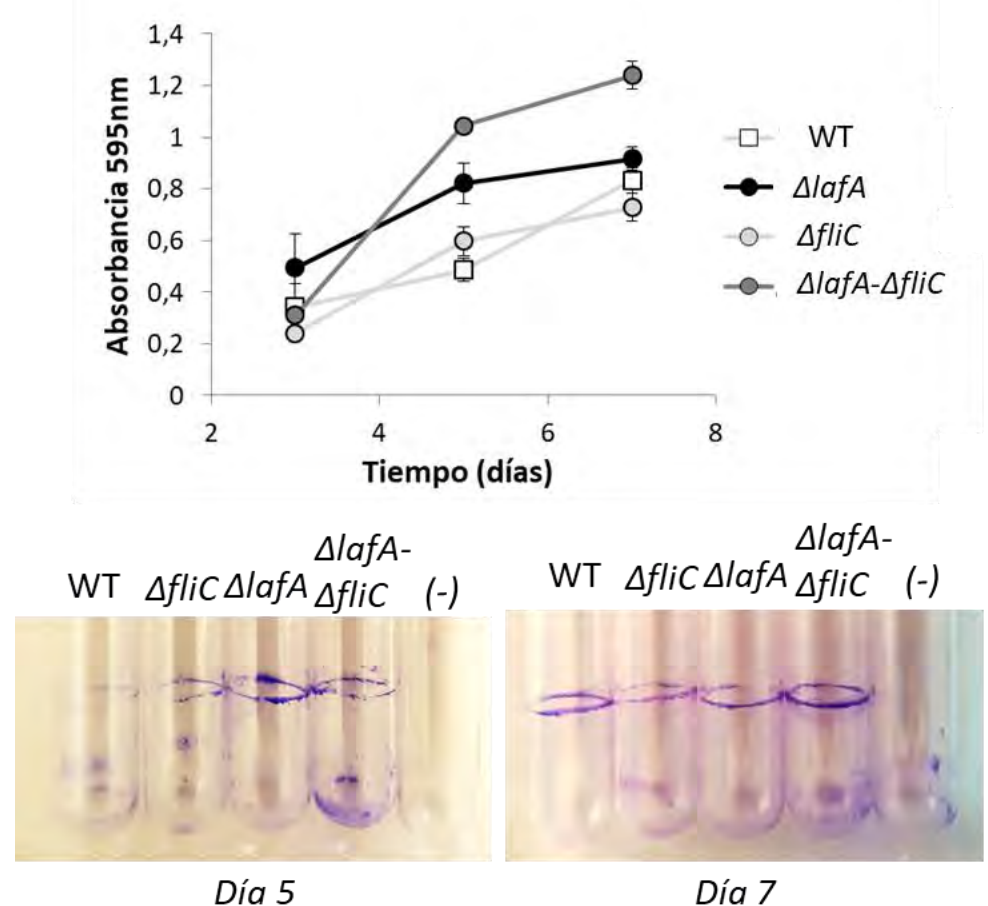

Figura V.23 - Adhesión a tubos de vidrio de los mutantes de $B$. diazoefficiens estructurales en las flagelinas de los dos sistemas flagelares. Arriba se grafica una réplica biológica representativa (de tres ensayos) en donde se muestra la absorbancia promedio del cristal violeta adherido. Abajo se muestran fotos a los 5 y 7 días. (-) muestra un tubo control sin inocular. 


\section{V.4.6 Efecto de la mutación de los reguladores de clase II sobre el proceso simbiótico}

Dado que los mutantes en $f l b D$ y flix tuvieron efectos pleiotrópicos, algunos de los cuales podrían estar asociados con su capacidad simbiótica, como la producción de EPS, nos preguntamos si esta característica podría estar afectada debido a las mutaciones. Para evaluar esto se realizó un ensayo de nodulación en plantas de soja. Como se muestra en la Tabla V.2, no se detectaron diferencias en el número de nódulos por planta ni en el peso seco de los nódulos. Esto indicaría que el proceso simbiótico estaría estableciéndose de manera normal, tal como se observó previamente en mutantes carentes de uno, otro o ambos flagelos (Althabegoiti et al., 2011).

Tabla V.2 - Ensayo de nodulación de plantas de soja por parte de los mutantes en los reguladores de clase II. El número de nódulos y peso seco de los mismos corresponden al promedio de 10 plantas y el error corresponde al valor del desvío estándar.

\begin{tabular}{|l|c|c|} 
& Nódulos por planta & $\begin{array}{c}\text { Peso seco de los nódulos } \\
(\mathrm{mg})\end{array}$ \\
\hline Sin inocular & - & - \\
WT & $12,60 \pm 5,80$ & $0,64 \pm 0,27$ \\
$\Delta f l b D$ & $11,80 \pm 6,80$ & $0,74 \pm 0,26$ \\
fliX::Km & $8,40 \pm 3,03$ & $0,74 \pm 0,23$ \\
$\Delta f l b D$-fliX::Km & $8,00 \pm 3,40$ & $0,61 \pm 0,27$ \\
\hline
\end{tabular}

\section{V.5 Conclusión y perspectivas}

Mediante el análisis de los mutantes presentados en este Capítulo, pudimos identificar a los reguladores de clase II, FlbD y FliX (codificados en los genes ubicados en blr7003 y bll5837 respectivamente) en B. diazoefficiens USDA 110. Estas dos proteínas resultaron indispensables para sintetizar el bastón distal y el gancho del flagelo subpolar en esta bacteria y no interfirieron en el control de la síntesis de los flagelos laterales, aunque sí provocaron una sobreexpresión de los mismos (visto a través de la sobreexpresión de lafR y cantidad de proteínas en SDS-PAGE). Además, FlbD participaría de una regulación fina independiente de FliX sobre algunos de los genes del flagelo subpolar necesarios en etapas previas y posteriores de la formación del bastón y gancho. Sumado a esto, encontramos que solo uno de los parálogos del factor $\sigma^{54}$ (Blr0723), denominado RpoN2 (Kullik et al., 1991), es requerido para la transcripción de estos genes y no existe complementación en trans con RpoN1 en este fenotipo.

Por otro lado, la mutación de flbD provocó la disminución de los niveles de ARNm de los genes que codifican proteínas del gancho que se encuentran en los clusters 5 y 6 
$\left(f l g E_{5}\right.$ y $\left.f l g D_{6}\right)$, pero no en los que se encuentran en el cluster 3 , apoyando la idea que este último cluster parecería no ser funcional en $B$. diazoefficiens.

Además, la disminución en la performance de natación observada en las cepas que sobreexpresan FlbD o FliX y la disminución en la cantidad de flagelinas subpolares sintetizadas en la cepa que sobreexpresó FlbD podría deberse a la expresión atemporal de este regulador transcripcional y por lo tanto a un freno en la cascada de la síntesis flagelar. Esta hipótesis permitiría explicar también la falta de éxito al intentar complementar del fenotipo de síntesis flagelar en la cepa $\triangle f l b D$-pB3::flbD.

Cuando evaluamos la cepa flbD-DxA fue capaz se sintetizar un flagelo subpolar funcional a pesar de que FlbD no posee el aminoácido (D52) sensible a fosforilación. En otras bacterias está propuesto que la regulación por fosforilación respondería a una vía de señalización que conecta la progresión del ciclo celular con la síntesis del flagelo. Esto no parecería ocurrir en $B$. diazoefficiens, en la cual además de no necesitar la fosforilación de FlbD para ser activo, la deleción de cualquiera de los dos genes que codifican reguladores de clase II ( $f l b D$ o fliX) no provoca una alteración en la división celular (no se observó la formación de estructuras filamentosas). De alguna manera parecería que los reguladores clase II se han especializado aún más en la función regulatoria flagelar y así la coordinación con el ciclo celular sería responsabilidad exclusiva de CtrA como iniciador de la cascada regulatoria del flagelo.

Adicionalmente, encontramos que en $B$. diazoefficiens, FlbD y FliX influyen en el proceso de formación de EPS ya que ambos mutantes presentaron una mayor cantidad y/o acumulación de los mismos. Sin embargo, el aumento de EPS no se trasladó a una mayor capacidad de formar biofilms. Así, hemos podido determinar, utilizando otra serie de mutantes estructurales, que el flagelo subpolar sería importante para la adhesión a superficies hidrofílicas (en este caso, vidrio), mientras que los flagelos laterales impedirían este proceso. Este rol del flagelo subpolar en el proceso de adhesión ha sido mencionado previamente por Quelas y colaboradores (2016a) mediante la cuantificación de bacterias adheridas a portaobjetos.

Por último, la mutación de los genes que codifican estos reguladores no afectaron la interacción de las bacterias con plantas de soja. 
Capítulo VI: Caracterización de posibles reguladores clase III (FlaF-FlbT) de la cascada de síntesis del flagelo subpolar de $B$. diazoefficiens USDA 110 



\section{VI.1 Introducción}

Las flagelinas son las últimas proteínas en ser sintetizadas y ensambladas para concluir la formación del filamento funcional de los flagelos bacterianos (McCarter, 2006). En la mayoría de las bacterias modelo estudiadas como E. coli, S. typhimurium, $V$. cholerae y $P$. aeruginosa, la transcripción de los genes que codifican las flagelinas dependen de un factor $\sigma$ alternativo (llamado $\sigma^{28}$ o FliA) y un factor anti-sigma (anti- $\sigma$ ) denominado FlgM. Como mencionamos en la Introducción, FlgM funciona como punto de control entre la construcción del gancho y la transcripción de las flagelinas (Karlinsey et al., 2000). Una vez que el gancho es ensamblado, el factor anti- $\sigma$ es secretado a través del mismo. Así, FliA queda libre y es capaz de unirse a los promotores de las flagelinas e iniciar la transcripción de las mismas (Ohnishi et al., 1990). En la gran mayoría de las $\alpha$-Proteobacterias, sin embargo, no se encuentran proteínas homólogas a FliA (Smith y Hoover 2009). En su lugar, se han encontrado un par de reguladores, denominados FlaF y FlbT que, en vez de modular la transcripción, actúan regulando los niveles de las flagelinas a nivel traduccional. Estos reguladores parecerían actuar también como checkpoint del estado de formación del gancho, para luego activar la traducción de las flagelinas en el momento necesario (Mangan et al., 1999; Llewellyn et al., 2005).

El mecanismo de control a través de FlaF y FlbT ha sido estudiado en diferentes microorganismos como C. crescentus, E. meliloti y B. melitensis (Mangan et al., 1999; Smith y Hoover 2009; Ferooz et al., 2011). Estos microorganismos poseen diferentes sistemas de regulación de la síntesis de sus flagelos, aunque comparten la última etapa a través de las proteínas FlaF y FlbT (Capítulo I-Figura I.7). A pesar de que estas proteínas son similares en secuencia (lo que ha llevado a denominarlas de la misma manera), funcionan de manera diferente en los distintos modelos conocidos.

\section{Rol de FlaF y FlbT en $C$. crescentus}

En este modelo regulatorio, FlbT es un regulador post-transcripcional que actúa como represor de la traducción de los mensajeros de las flagelinas. Anderson y Gober (2000) demostraron que FlbT de C. crescentus se une a un loop en la región 5' no traducida del ARNm de una de sus flagelinas, estabilizando una estructura secundaria que oculta la secuencia de unión al ribosoma y resulta inestable, favoreciendo de esta forma la degradación de sus mensajeros. Para que dicha unión se establezca, resultaría necesaria la participación de una segunda proteína, aunque la misma no ha sido identificada hasta el momento (Anderson y Gober, 2000). Mutantes en flbT presentan un filamento deslocalizado y de tamaño variable, que provoca un defecto en su capacidad de natación (Schoenlein y Ely, 1989; Llewellyn et al., 2005). Además, si a mutantes estructurales del gancho se les muta también $f l b T$, el fenotipo de síntesis de flagelinas se restaura. Esto significa que FlbT se encuentra asociada al punto de control 
(checkpoint) de finalización de la construcción del gancho. Asimismo, las cepas que no expresan FlbT, no solo poseen afectada su capacidad de formar un filamento funcional, sino que además presentan defectos en quimiotaxis y en la integridad de su membrana (Schoenlein y Ely, 1989).

Por otro lado, FlaF parece actuar de manera inversa a FlbT. La función de FlaF es requerida para la traducción de algunas de las flagelinas de $C$. crescentus y mutantes deficientes en esta proteína son incapaces de formar el filamento, y por lo tanto, no pueden moverse por natación (Schoenlein et al., 1992; Llewellyn et al., 2005). De acuerdo con estos resultados, FlaF se comporta como un activador de la traducción.

A su vez, los niveles proteicos de FlbT permanecen constantes durante todo el ciclo celular, mientras que los niveles de FlaF varían con el mismo, coincidiendo su patrón de expresión temporal con el patrón de expresión de las flagelinas (Llewellyn et al., 2005). De acuerdo con estos autores, el modelo postula que FlbT estaría favoreciendo la degradación de los ARNm de las flagelinas hasta que se completa la construcción del gancho. Así, se consigue evitar la traducción dentro de la célula de miles de copias de flagelinas que no son necesarias en un primer momento, pero que serán requeridas luego para generar el filamento funcional. En este punto FlaF se acumula, desplaza el efecto negativo de FlbT y promueve la traducción de las flagelinas. Una vez ensamblado el filamento, los niveles de FlaF bajan, lo que podría deberse a un mecanismo regulatorio mediado por proteólisis programada dependiente del estado de formación del flagelo (Llewellyn et al., 2005). El mecanismo de acción mediante el cual FlaF activa la traducción de las flagelinas, así como los participantes involucrados en el punto de control del gancho, aun no se conocen.

\section{Rol de FlaF y FlbT en B. melitensis}

En B. melitensis y E. meliloti el sistema regulatorio a través de FlaF y FlbT fue caracterizado parcialmente. A diferencia del modelo descripto anteriormente, en $B$. melitensis FlbT es un regulador positivo de la síntesis de flagelinas, ya que su mutación disminuye la cantidad de transcripto de las flagelinas y su expresión (Ferooz et al., 2011). Por otro lado, la sobreexpresión de FlaF impide la síntesis de flagelinas, por lo que estaría actuando negativamente sobre la estabilidad de estas proteínas (Ferooz et al., 2011). Asimismo, FlbT de E. meliloti también es capaz de estabilizar las flagelinas de B. melitensis, mientras que FlbT de $C$. crescentus no puede hacerlo.

Queda claro que en estos microorganismos las funciones de FlaF y FlbT sobre la síntesis de las flagelinas es sustancialmente diferente, a pesar de que comparten la una similitud de secuencia muy alta, lo que permite agruparlas en la misma familia de proteínas.

En este trabajo de Tesis, abordaremos el análisis del rol de $\mathrm{FlbT}_{\mathrm{S}}$ y $\mathrm{FlaF}_{\mathrm{S}}$ en la síntesis flagelar de B. diazoefficiens USDA 110. 


\section{VI.2 Análisis bioinformático de FlaF y FlbT asociadas al flagelo subpolar de B. diazoefficiens}

B. diazoefficiens posee dos genes parálogos que codifican FlbT y otros dos que codifican FlaF. Con el fin de facilitar su identificación, hemos nombrado como $f l b T_{S}$ y fla $_{S}$ a los genes que se encuentran codificados en el cluster 5 del flagelo subpolar y $f l b T_{L}$ y fla $F_{L}$ para las que se encuentran en el único cluster de los flagelos laterales.

De acuerdo con los resultados mostrados en los Capítulos anteriores, el modelo de regulación del flagelo subpolar en $B$. diazoefficiens se asemejaría al que se ha descripto en $C$. crescentus. Por este motivo, hipotetizamos que tanto $\mathrm{FlbT}_{\mathrm{S}}$ como $\mathrm{FlaF}_{\mathrm{S}}$ podrían actuar como reguladores de clase III. Recientemente, hemos descripto la función de $\mathrm{FlbT}_{\mathrm{L}}$ como activador de la traducción de las flagelinas del sistema flagelar lateral, de manera similar a lo que sucede en E. meliloti y B. melitensis (Mongiardini et al., 2017). Ello, sumado a la baja similitud de secuencia entre ambos pares, justificaría la falta de complementación en trans entre las dos copias de flbT (Mongiardini et al., 2017). Esto podría deberse a una falta en la coordinación de la expresión de estas proteínas o a una diferencia en el funcionamiento entre ellas.

FlaF y FlbT son proteínas muy pequeñas (alrededor de 150 aminoácidos) y no poseen dominios característicos conservados de unión a ARN. Con el propósito de determinar si existe una diferencia en secuencia que pueda soportar la hipótesis planteada previamente, realizamos un estudio filogenético utilizando las dos proteínas homólogas a FlaF y FlbT presentes en $B$. diazoefficiens USDA 110. El árbol filogenético obtenido (Figura VI.1-A) mostró que la copia de FlaFs se ubicó en el mismo grupo que FlaF de $C$. crescentus (recuadros rojos), mientras que la copia FlaF $_{L}$ se asoció con FlaF de $B$. melitensis y $E$. meliloti (recuadros verdes). Un resultado similar observamos con $\mathrm{FlbT}_{\mathrm{S}}$ y $\mathrm{FlbT}_{\mathrm{L}}$ (Figura VI.1-B). Estos resultados indicarían que las copias de $\mathrm{FlaF}_{\mathrm{S}}$ y $\mathrm{FlbT}_{\mathrm{S}}$ ubicadas en el cluster 5 tendrían funciones similares a las del modelo de $C$. crescentus.

Para confirmar la función de los reguladores $\mathrm{FlaF}_{\mathrm{S}}$ y $\mathrm{FlbT}_{\mathrm{S}}$ codificados en los genes bll5842 y blr5847 respectivamente, y continuar desentrañando la cascada de señalización de la síntesis del flagelo subpolar, comenzamos con la mutación de estos genes en $B$. diazoefficiens USDA 110 y la posterior caracterización de las cepas mutantes obtenidas. 
A

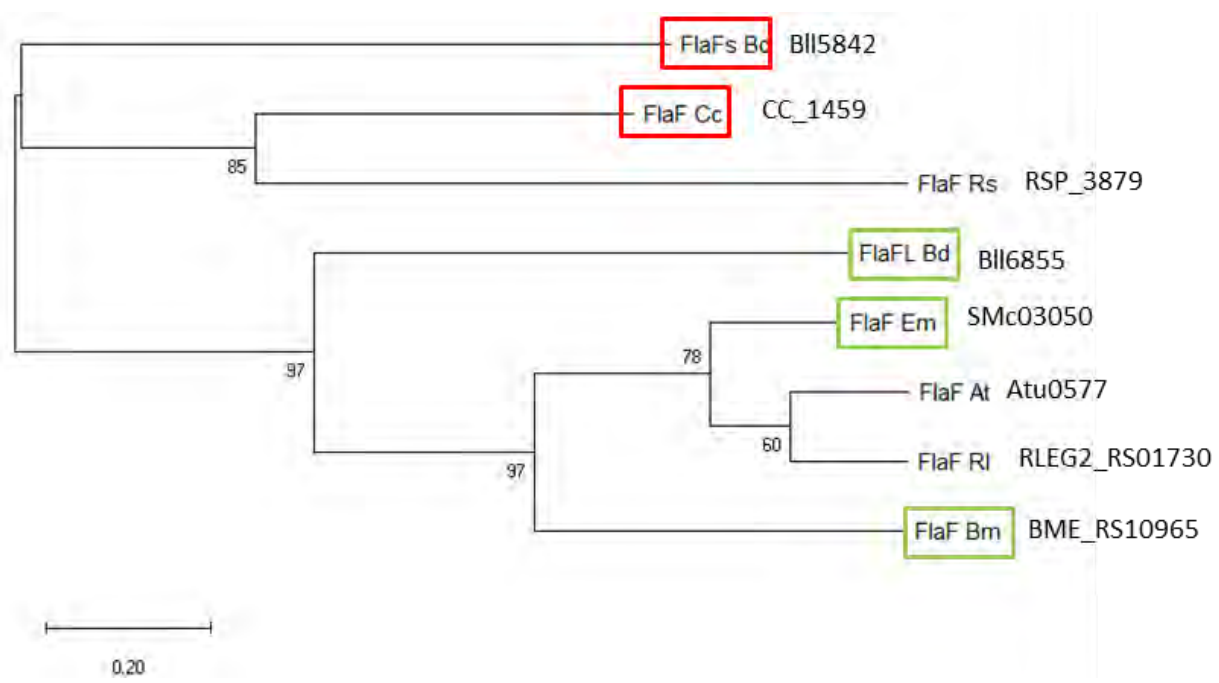

B

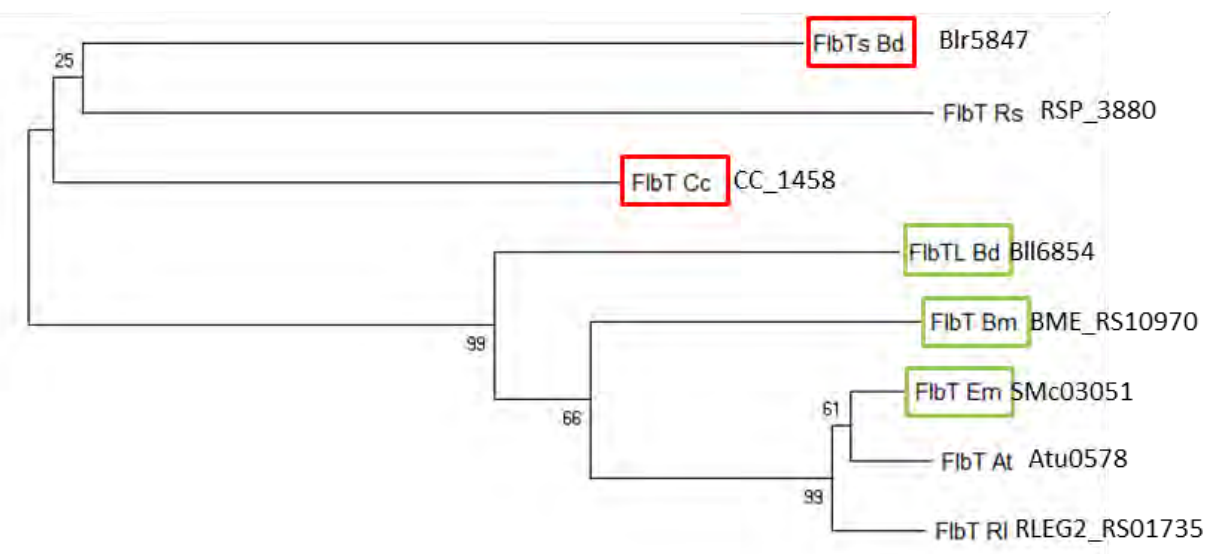

0.20

Figura VI.1 - Árboles filogenéticos de FlaF (A) y FlbT (B) y homólogos con función conocida. Los árboles se construyeron en MEGA $X$ por el método Maximum Likelihood con un bootstrap de 1000 utilizando alineamientos realizados en MUSCLE. Las abreviaturas utilizadas en los árboles son: Bd: B. diazoefficiens, Cc: C. crescentus, Rs: R. sphaeroides, Em: E. meliloti, At: Agrobacterium tumefaciens, Rl: Rhizobium leguminosarum, Bm: B. melitensis

\section{VI.3 Obtención de mutantes de B. diazoefficiens en fla $_{S}$ y $f l b T_{S}$}

Para la construcción del mutante en el gen flaF (bll5842), se utilizó la estrategia de mutagénesis por doble recombinación homóloga (Figura VI.2) utilizando la técnica diseñada por Sukdeo y Charles (2003) y puesta a punto en nuestro laboratorio. 


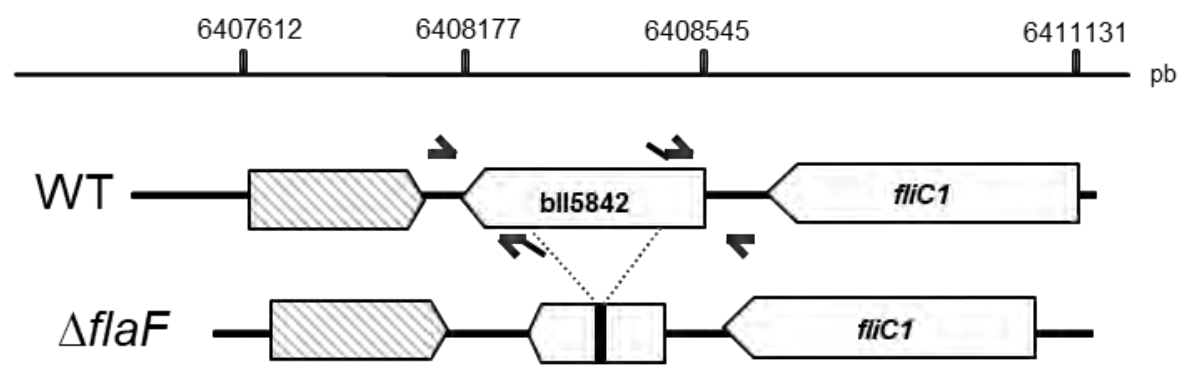

Figura VI.2 - Mapa esquemático del gen flaFy genes vecinos (c/uster 5) que muestra el diseño utilizado para su mutagénesis en $B$. diazoefficiens USDA 110. La estrategia utilizada consistió en amplificar la región $5^{\prime}$ y $3^{\prime}$ por separado del gen candidato. Los primers internos poseen una secuencia de nucleótidos complementaria entre sí que promueve su pegado para una tercera amplificación con los primers externos. De esta manera queda amplificado un fragmento con una deleción de la región interna del gen. Los símbolos rayados son genes que no guardan relación con ningún componente flagelar.

Para obtener el plásmido necesario para realizar la mutación, comenzamos amplificando por PCR dos fragmentos de ADN de ambos extremos del gen. La región Up (entre las bases 6.407.980 a 6.408.237) de 294 pb utilizando los primers Up5842_FwE-Up5842_Rv y la región Dw (entre las bases 6.408 .542 a 6.408 .775 ) de 272 pb con los primers Dw5842_Fw-Dw5842_RvH (Figura VI.4-A). Posteriormente, utilizando los primers externos en una nueva reacción de PCR y como molde los productos de amplificación de las reacciones previamente descriptos, se amplificó un fragmento de $547 \mathrm{pb}$ denominado UpDw, el cual fue clonado en pK18mobsacB utilizando las enzimas de restricción EcoRI y HindllI (agregadas en los mismos primers) dando el plásmido pKsacB::5842 (Figura VI.4-B). Esta construcción se movilizó a $B$. diazoefficiens USDA 110 para obtener un mutante (siguiendo el protocolo descripto en Materiales y Métodos) al que denominamos $\Delta$ flaF. Dicho mutante fue chequeado por PCR utilizando primers externos a la zona de recombinación denominados Ext5842_Fw-Ext5842_Rv cuyo amplicón fue de 889 pb, (Figura VI.4-C, D) y su mutación fue corroborada por secuenciación.

El mutante $f \mid b T:: \mathrm{Km}$ fue obtenido por el Dr. Juan Ignacio Quelas (sin publicar) y en este caso la estrategia de mutación elegida fue por interrupción de la secuencia de flbT (blr5847) utilizando el sitio BamHI presente en dicho gen (Figura VI.3). Dicho mutante se obtuvo movilizando un plásmido con el gen flbT interrumpido por el cassette $\mathrm{Km}$ (denominado pG18mobLK::flbT::Km) hacia B. diazoefficiens USDA 110 para luego buscar dobles recombinantes resistentes a $\mathrm{Km}$ y sensibles a $\mathrm{Gm}$. A su vez, nosotros movilizamos dicho plásmido hacia la cepa mutante $\Delta f l a F$, generando un doble mutante que denominamos $\Delta$ flaF-flbT::Km. 


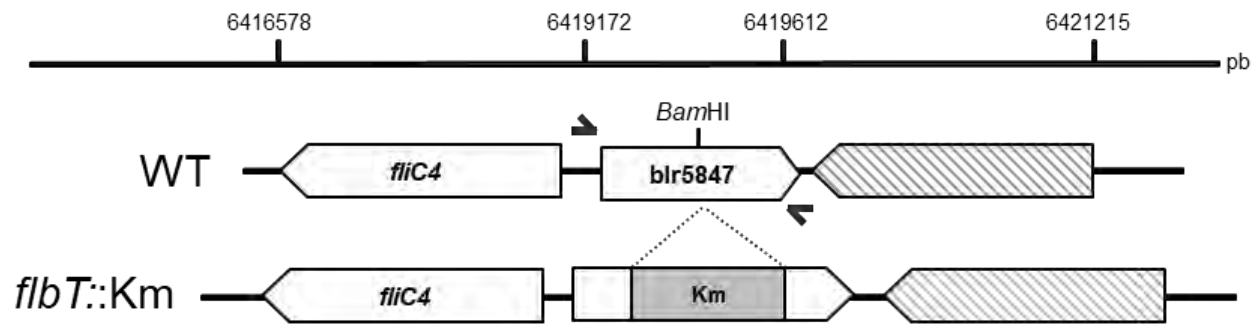

Figura VI. 3 - Mapa esquemático del gen flbT (bll5847) y genes vecinos (cluster 5) que muestra el diseño utilizado para su mutagénesis en $B$. diazoefficiens USDA 110. La estrategia consistió en amplificar el gen por PCR y clonar en el sitio BamHI que se ubica dentro del gen, un cassette de antibiótico que le otorga resistencia a kanamicina. Los símbolos rayados son genes que no guardan relación con ningún componente flagelar.

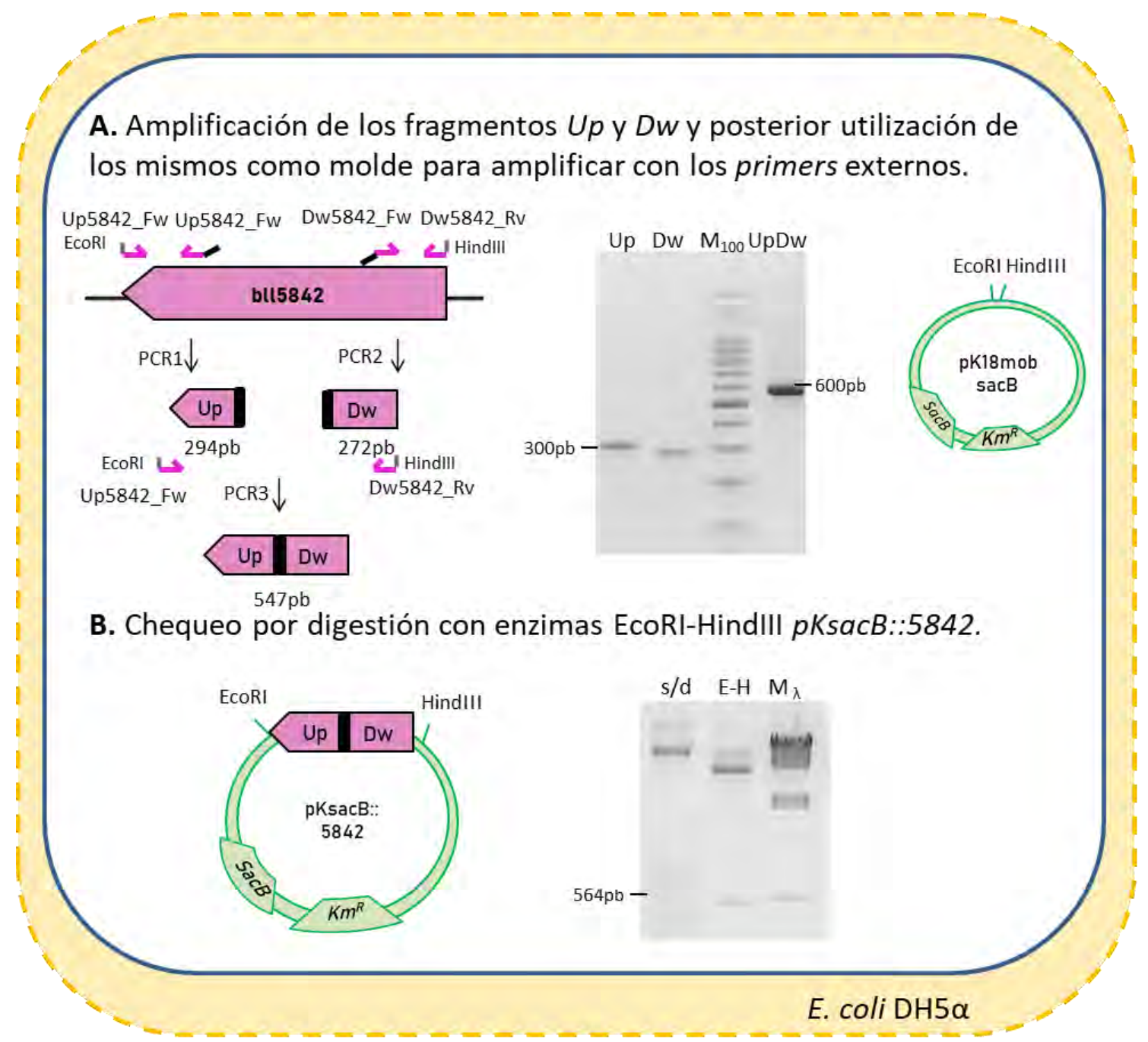




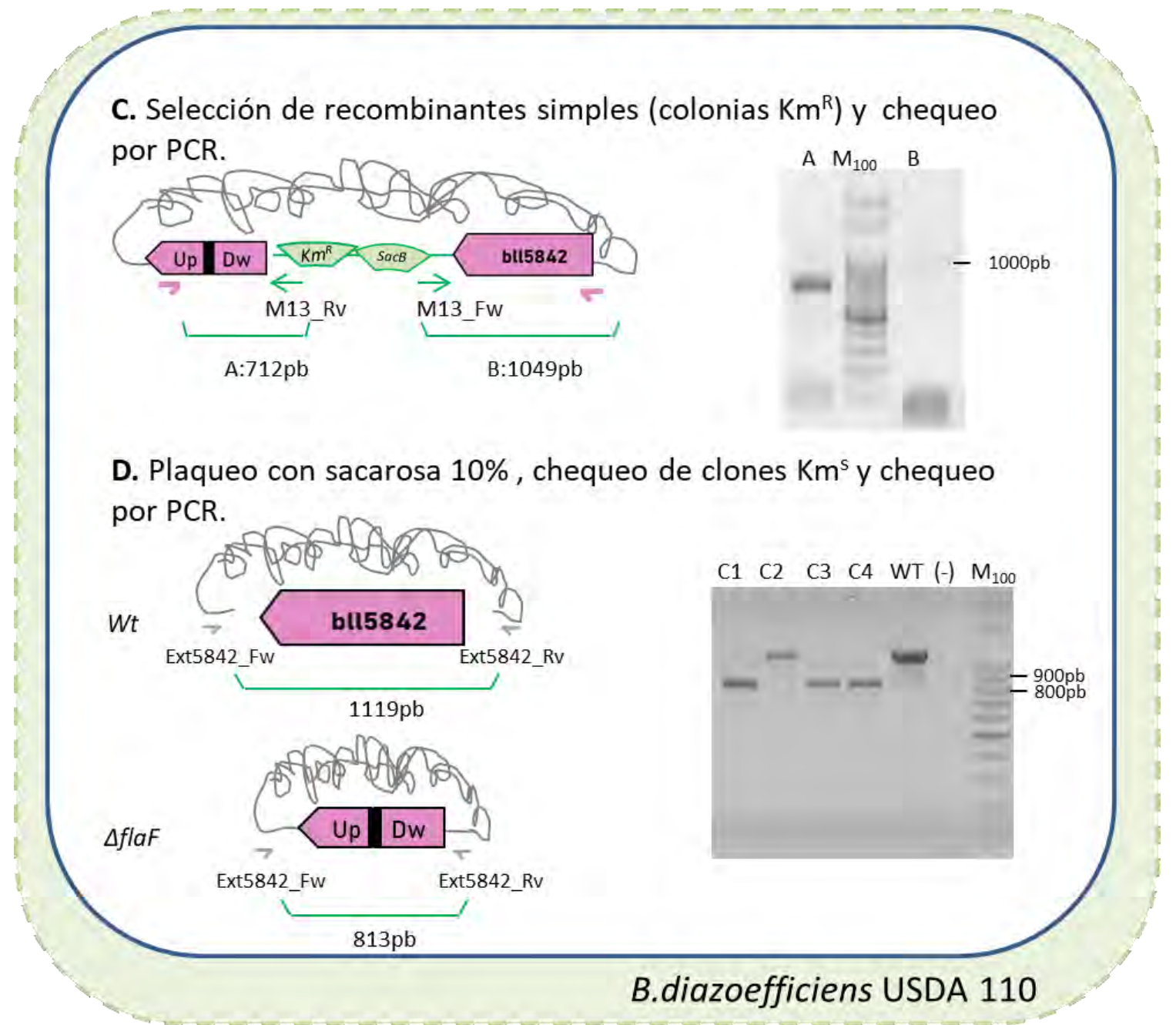

Figura VI.4 - Esquema del clonado y selección de la cepa mutante de $B$. diazoefficiens $\triangle f l a F$. El gráfico con el recuadro amarillo representa los pasos de clonación para obtener el plásmido pKsacB::5842. El gráfico con el recuadro verde muestra un esquema del cromosoma de $B$. diazoefficiens WT y mutante con énfasis en el gen flaF y su comprobación por PCR (gel de agarosa. Up, Dw y UpDw representan las PCR1, PCR2 y PCR3 de la técnica de amplificación por PCR de Sukdeo y Charles (2003) descripta en Materiales y Métodos (Capítulo II.4.9). En los geles de agarosa, $M_{100}$ y $M_{\lambda}$ representan marcadores de peso molecular de $100 \mathrm{pb}$ y $\lambda$-HindIII, respectivamente. $s / \mathrm{d}$ representa el plásmido sin digerir. Con la letra $\mathrm{C}$ y un número se indican diferentes clones chequeados por PCR durante los chequeos (D). En el caso de digestiones se indican las enzimas de restricción utilizadas con las iniciales de su respectivo nombre. WT indica el control con ADN de la cepa WT y (-) el control negativo con agua.

\section{VI.3.1 Caracterización de los mutantes de B. diazoefficiens en fla $F_{S}$ y flbTS}

Para comenzar la caracterización de los mutantes $\Delta f l a F, f l b T:: \mathrm{Km}$ y $\Delta f l a F-f l b T:: \mathrm{Km}$ caracterizamos su crecimiento en medio líquido AG. Como esperábamos, no se observaron diferencias significativas en el comportamiento de las tres cepas mutantes comparados con la cepa WT, a juzgar por las absorbancias de los cultivos $\mathrm{DO}_{500}$ en función del tiempo (Figura VI.5-A). Con el fin de evaluar el rol de $\mathrm{FlaF}_{\mathrm{S}}$ O $\mathrm{FlbT}_{\mathrm{S}}$ sobre la síntesis de los filamentos de ambos sistemas flagelares de $B$. diazoefficiens, se analizó 
la presencia de flagelinas en los sobrenadantes de cultivos líquidos de acuerdo con el método descripto previamente (Capítulo II.5). En la Figura IV.5-B podemos observar que tanto el mutante $\Delta$ flaF como el doble mutante $\Delta$ flaF-flbT::Km, no fueron capaces de sintetizar flagelinas subpolares cuando fueron crecidas en cultivo líquido mientras que el mutante $f \mid b T:: K m$ fue capaz de sintetizarlas al igual que la cepa WT. Este resultado concuerda con la hipótesis de que $\mathrm{FlaF}_{S}$ sería un regulador positivo, necesario para la síntesis de las flagelinas subpolares y que actuaría de manera similar a como ejerce su acción su homólogo en $C$. crescentus.

A su vez, considerando que en el mutante $f l b T:: \mathrm{Km}$ las flagelinas subpolares se siguen sintetizando normalmente, y asumiendo que $\mathrm{FlaF}_{\mathrm{S}}$ es un regulador positivo, podríamos suponer que $\mathrm{FlbT}_{\mathrm{S}}$ estaría actuando como regulador negativo. Finalmente, el doble mutante incapaz de sintetizar los dos reguladores, tampoco fue capaz de sintetizar las flagelinas subpolares, como ocurrió en el mutante simple $\Delta$ fla $F$.

A

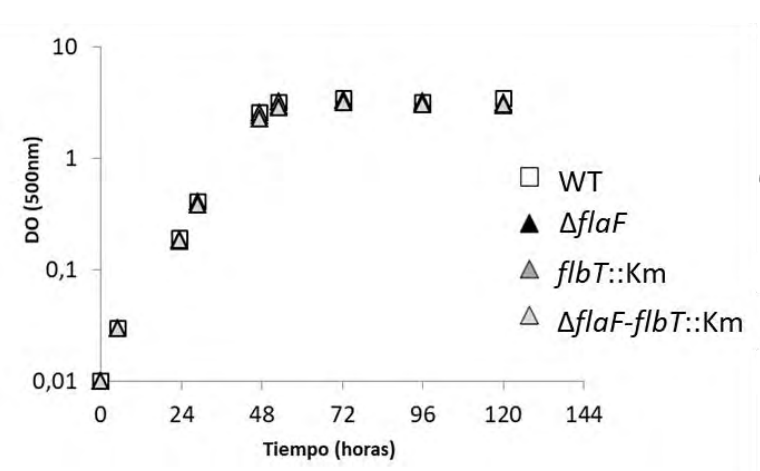

B

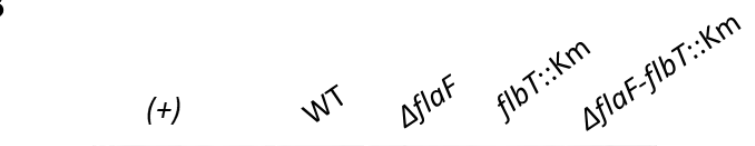

$33 k D a-$

$65 k D a-$
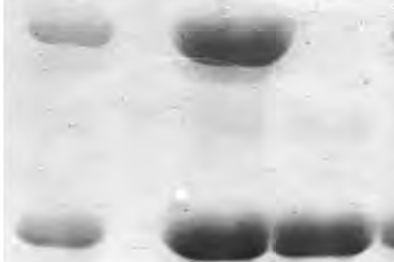

Figura VI.5 - Cinética de crecimiento (A) y perfil de flagelinas de las cepas de $B$. diazoefficiens mutantes en flaFy flbT. A. Medida de densidad óptica $\left(\mathrm{DO}_{500 \mathrm{~nm}}\right)$ de la cepa WT y los mutantes en flaF y flbT. El gráfico muestra un ensayo representativo de dos réplicas biológicas. El desvío estándar queda dentro de los símbolos. B. SDS-PAGE de flagelinas extracelulares de cultivos líquidos.

\section{VI.3.2 Efecto de la mutación de $f l b T_{S}$ y fla $F_{S}$ sobre los niveles de transcripción de los genes de las flagelinas subpolares}

Para corroborar si la función activadora de $\mathrm{FlaF}_{\mathrm{S}}$ tenía un efecto sobre los transcriptos de las flagelinas subpolares de $B$. diazoefficiens y evaluar si efectivamente $\mathrm{FlbT}_{\mathrm{S}}$ actuaba como represor sobre estos mismos transcriptos, realizamos ensayos de qRT-PCR. Para ello, diseñamos primers específicos para cada uno de los ORF que codifican las cuatro flagelinas que forman el filamento subpolar. Dada la gran similitud nucleotídica en la secuencia codificante de los genes de las flagelinas flic2, flic3 y flic4 diseñamos primers que hibridaran en la región 5'UTR de cada una de ellas (Tabla VI.1 y Anexo Figura AVI.1). 
Tabla VI.1 - Porcentaje de similitud de secuencia nucleotídica y aminoacídica entre las cuatro flagelinas subpolares.

flic1

\section{nucleótidos}

flic2

flic3 flic4

$73 \%$

flic3

\begin{tabular}{|r|r|r|}
\hline $73 \%$ & $73 \%$ & FliC1 \\
\hline $93 \%$ & $93 \%$ & FliC2 \\
\hline & $97 \%$ & FliC3 \\
\hline
\end{tabular}

aminoácidos

$\begin{array}{lll}\text { FliC2 } & \text { FliC3 } & \text { FliC4 } \\ 74 \% & 73 \% & 74 \% \\ & 94 \% & 94 \% \\ & & 98 \%\end{array}$

El mutante $\triangle$ flaF presentó una disminución de los niveles de transcripto de las flagelinas flic234 con respecto a la cepa WT. En cambio, los niveles de ARNm de flic1 permanecieron sin variaciones significativas. Por otro lado, el mutante flbT::Km presentó un aumento de flic234, confirmando así su acción negativa sobre estos ARNm. Nuevamente, los niveles de transcripto de flic1 permanecieron constantes en este mutante. Parecería entonces que el nivel de ARNm de flic1 (la copia que comparte menor similitud de secuencia con las restantes) es diferente e independiente del control jerárquico que sucede sobre los otros tres genes que codifican flagelinas subpolares.

Confirmada la función negativa de FlbTs sobre los niveles de ARNm de los genes codificantes de las flagelinas subpolares flic234, podríamos suponer que la ausencia de estas flagelinas en el mutante $\triangle$ flaF (Figura VI.5-B) no se debía únicamente a la función negativa de $\mathrm{FlbT}_{\mathrm{s}}$, dado que en el doble mutante $\Delta$ flaF-flbT::Km tampoco fueron sintetizadas (Figura VI.5-B). Esto indica que el regulador $\mathrm{FlaF}_{S}$ podría no solo tener una función regulatoria positiva sobre los transcriptos, sino que además podría ser necesario para activar la traducción.

Tabla VI.2 - Medidas de QRT-PCR de los cuatro genes que codifican flagelinas subpolares sobre los mutantes en los reguladores de clase III de $B$. diazoefficiens. Los datos se encuentran representados como el promedio del foldchange de dos ensayos independientes.

\begin{tabular}{|c|cc|}
\hline & $\Delta f l a F$ & $f l b T:: K m$ \\
\hline flic1 & $\mathrm{SC}$ & $\mathrm{SC}$ \\
\hline flic2 & $-2,3 \pm 0,8$ & $5,8 \pm 3,8$ \\
\hline flic3 & $-2,7 \pm 0,3$ & $2,6 \pm 0,2$ \\
flic4 & $-6,1 \pm 5,5$ & $3,5 \pm 0,6$ \\
\hline
\end{tabular}

SC (sin cambios significativos). 


\section{VI.3.3 Efecto de la mutación de flbTs y flaFs sobre la movilidad bacteriana}

Con motivo de evaluar funcionalidad de los flagelos en las cepas mutantes, realizamos ensayos de natación en medio semisólido.

Como esperábamos, se observó una disminución de la movilidad de los mutantes $\Delta$ flaF y $\Delta$ flaF-flbT::Km, producto de la incapacidad de ambas cepas de sintetizar flagelinas subpolares. Por otro lado, el mutante $f l b T:: \mathrm{Km}$ nadó igual que la cepa WT, por lo que la falta de este regulador no parecería afectar la síntesis y funcionalidad de ninguno de los dos sistemas flagelares (Figura VI.5-B).

Llamativamente, se observó una diferencia de natación entre la mutante $\Delta$ flaF y el doble mutante $\Delta$ flaF-flbT::Km. Si bien ambas cepas carecen de flagelinas subpolares, la doble mutante presentó un halo de natación significativamente mayor que la mutante simple $\Delta$ flaF (Figura VI.5-B).

Esta observación motivó que realizáramos una purificación de flagelinas de estos mutantes, pero esta vez nadando en placas de agar semisólido (Figura VI.6). Así, en la cepa WT se vieron claramente las dos bandas características de las flagelinas subpolares y también las laterales, pero en el mutante $\Delta$ flaF sólo se observó la presencia de flagelinas laterales (al igual que en los cultivos líquidos). El doble mutante presentó, además de las bandas correspondientes a las flagelinas laterales, una pequeña banda a la altura de las flagelinas subpolares. Ello podría indicar que la cepa mutante $\Delta f l a F-f l b T:: \mathrm{Km}$ presentaría filamentos correspondientes al flagelo subpolar, lo cual podría explicar su mayor capacidad de natación con respecto a la cepa $\Delta$ fla $F$ (Figura VI.5-A). Resta confirmar esta hipótesis por microscopía electrónica. 
A

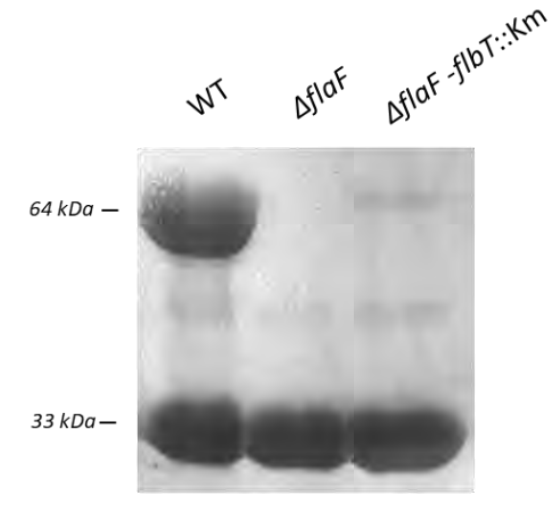

B
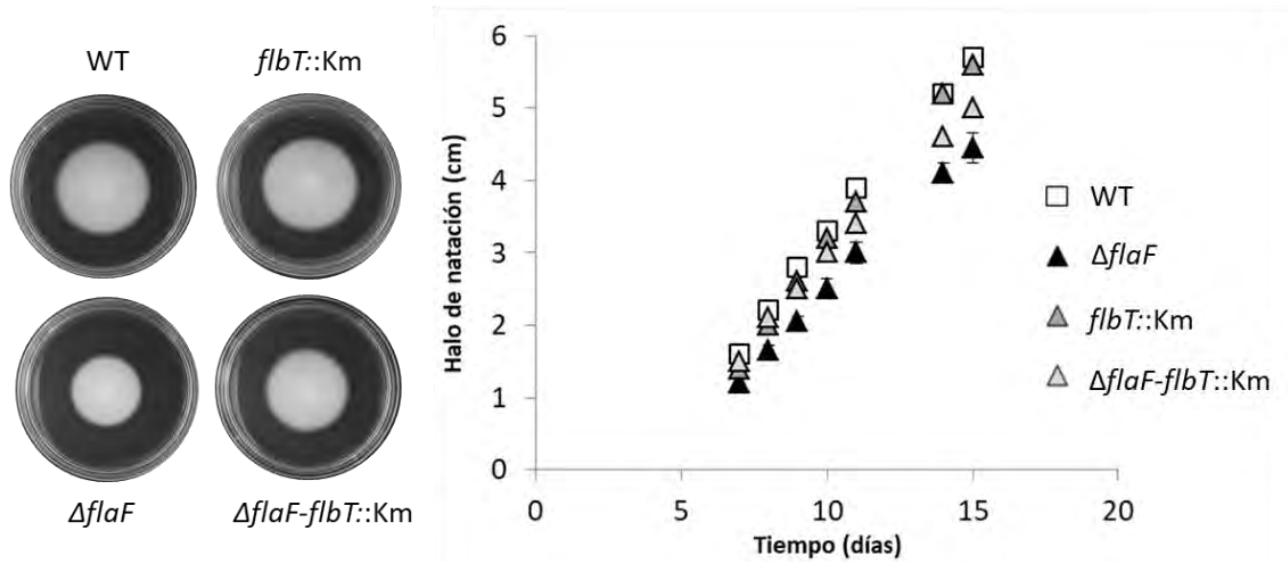

Figura VI.6 -Perfil de flagelinas (A) y ensayos de movilidad en agar semisólido (B) de las cepas mutantes de $B$. diazoefficiens en flaF y flbT A. SDS-PAGE de flagelinas extracelulares extraídas de placas de natación. B. Foto representativa de placas de natación en agar semisólido a los 15 días. Los halos de natación de tres réplicas técnicas fueron registrados en función de los días y graficados con el desvío estándar. Estos ensayos fueron repetidos en dos oportunidades.

Con el fin de verificar si esta mayor capacidad de natación se debía a la formación de un filamento subpolar funcional (aunque menos eficiente), realizamos una deleción de los genes codificantes de las flagelinas laterales (lafA12) de manera de independizarnos del aporte de este sistema flagelar en la natación en agar semisólido. De esta forma, obtuvimos los mutantes dobles $\Delta$ lafA- $\Delta$ fla $F$ y el mutante triple $\Delta$ lafA$\Delta$ flaF-flbT::Km. Como control se utilizó la cepa WT que posee ambos sistemas intactos y una cepa carente de las flagelinas laterales denominada $\Delta$ lafA (Figura VI.7).

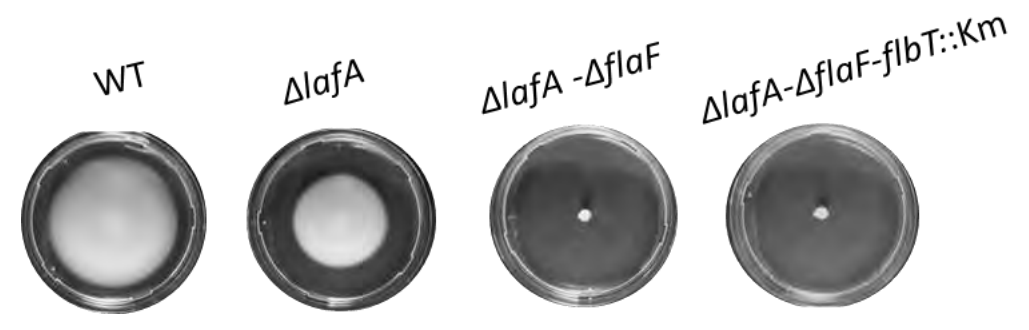

Figura VI.7 - Ensayo de movilidad en agar semisólido de mutantes de B. diazoefficiens carentes de flagelinas laterales y de los genes flaFy flbT. Fotos representativas de un ensayo de natación en agar semisólido. 
Sorpresivamente, encontramos que tanto el mutante doble $\Delta$ lafA- $\Delta$ flaF como el mutante triple $\Delta / a f A-\Delta f l a F-f l b T:: K m$ no fueron capaces de moverse. Por tal motivo, suponemos que la banda observada en el gel SDS-PAGE del doble mutante $\Delta$ flaF$f l b T:: \mathrm{Km}$ (Figura VI.6-B) podría corresponder a las flagelinas subpolares pero éstas no serían capaces de ensamblarse formando un filamento funcional.

Como habíamos determinado en el Capítulo V, la ausencia del flagelo subpolar induciría un aumento en la expresión del sistema de flagelos laterales, tanto si se mutan los genes de las flagelinas subpolares (flic1234) como si se delecionan los genes que codifican reguladores de clase II (mutantes $\Delta f(b D$ y fliX::Km). La diferencia en la capacidad de natación entre las cepas $\Delta$ flaF y $\Delta$ flaF-flbT::Km podría deberse entonces a un efecto similar, de regulación cruzada entre ambos sistemas y por lo tanto la diferente capacidad de natación se deba a una diferencia en los niveles de expresión del sistema de flagelos laterales.

A raíz de este último resultado, decidimos medir los niveles de transcripto del regulador maestro del flagelo subpolar lafR a través de qRT-PCR, el mutante $\triangle$ flaF no mostró cambios significativos (foldchange: $-1,03$ ) a diferencia de las cepas mutantes en reguladores de clase II. Al momento de esta tesis, aún resta medir los niveles de lafR en el mutante $\Delta$ flaF-flbT::Km para determinar si los mismos se encuentran aumentados en esta cepa.

\section{VI.3.4 Composición del filamento del mutante de $B$. diazoefficiens en flbT::Km}

Hasta el momento, sabemos que el mutante $f l b T:: \mathrm{Km}$ posee aumentados los niveles de transcripto de las flagelinas flic234. A su vez, este cambio no produjo una diferencia fenotípica apreciable respecto a su capacidad de natación en medio semisólido. Sin embargo, el cambio en los niveles de transcripto de estas flagelinas en $f l b T:: K m$ podría verse traducido en una modificación de la composición del filamento del flagelo subpolar. Para analizar esto, se realizaron extracciones de flagelinas a partir de cultivos líquidos de la cepa WT y el mutante $f l b T:: \mathrm{Km}$ a $D_{500}$ similares y se sembraron iguales cantidades de muestra en un gel SDS-PAGE. Las bandas correspondientes a las flagelinas subpolares de la cepa WT y mutante fueron analizadas en el CEQUIBIEM (Centro de Estudios Químicos y Biológicos por Espectrometría de Masas) mediante espectrometría de masas. Ver Materiales y Métodos para más detalles.

La metodología consistió en cuantificar la cantidad de veces que se identifica un péptido determinado correspondiente solamente a cada una de las copias de flagelinas subpolares (Quelas et al., 2016a). En la Tabla VI.3 se muestra la cantidad y secuencia de los péptidos únicos para cada flagelina subpolar luego de una digestión tríptica in silico de las mismas. Dado el alto grado de similitud de secuencia aminoacídica entre 
las cuatro flagelinas, sólo existen entre 5 y 9 péptidos únicos que nos permiten identificar a cada una de ellas.

La cantidad de péptidos únicos (Peptide Spectrum Matches o PSM) detectados fueron relativizados en función de la suma de todos de los péptidos únicos de las cuatro flagelinas subpolares detectados (Tabla VI.4). Como resultado de este análisis encontramos que las cantidades relativas de FliC1 y FliC4 permanecieron inalterables en la cepa WT respecto de la mutante flbT::Km. Por otro lado, Flic2 se encontró tres veces más representada en la cepa mutante comparado con la cepa WT y de manera opuesta, la flagelina Flic3 se encontró dos veces menos representada en la cepa mutante que en la cepa WT (Tabla VI.4). Este análisis es preliminar, ya que solo fue realizado sobre una única réplica biológica.

Tabla VI.3 - Secuencias de péptidos únicos para cada flagelina. La Tabla muestra los péptidos diferenciales para cada copia de flagelina obtenidos de una digestión triptica.

\begin{tabular}{|c|c|}
\hline Flagelina & Secuencia de péptidos únicos \\
\hline FliC1 & $\begin{array}{l}\text { VNTALDNPTNFFTAQGLDNR } \\
\text { SEGSALGSNLSIVQVR } \\
\text { ATVNDVLSAIDLASGVK } \\
\text { SNVSTTIPGATPADLR } \\
\text { STTAGSLGTLVQDGSTLNIDGHTITFK } \\
\text { KVNTALDNPTNFFTAQGLDNR } \\
\text { ASDISNLLDGINNGVQVLQAANTGITSLQK } \\
\text { QNLLSLQSTADLLATTQER } \\
\text { VLTSLNAASSTLR }\end{array}$ \\
\hline FliC2 & $\begin{array}{l}\text { SEASSLGSNLSVVQIR } \\
\text { ALGLTTSTGAGNATVNVNR } \\
\text { SSLNITGVTYNSK } \\
\text { VLTNLNAASSTLR } \\
\text { TSGIGGIAGK } \\
\text { NAPIPGSTGAPSVPSGYGASGNILTDGNGNSTVYLQAGTVNDVLK* } \\
\text { LVFDETGKSSLNITGVTYNSK* }\end{array}$ \\
\hline FliC3 & $\begin{array}{l}\text { GLGLAALTGGVDFIDNAATNK } \\
\text { SEASSLGSNLTIVQVR } \\
\text { ASLVNQYNNILNQIDSTSQDSSFNGVNLLNGDQLK }^{\mathbf{x}} \\
\text { VLTNLNSASSTLR }^{\mathbf{x}} \\
\text { QNLLSLQSTADLLATTQSR }^{\mathbf{x}}\end{array}$ \\
\hline FliC4 & $\begin{array}{l}\text { GLGLAALTSGVDFIDNAATNK } \\
\text { SLINVLQTGSSNLTLADTNTEAANSQALSTR } \\
\text { SEASSLGSNLSVVQVR } \\
\text { SNVSATISGATAADLR } \\
\text { SEASSLGSNLSVVQVRQDFNK } \\
\text { VLSNLNAASSTLR }\end{array}$ \\
\hline
\end{tabular}

Con asterisco $(*)$ y en negrita se marcan los péptidos que no pudieron ser identificados en la cepa mutante $f l b T:$ :Km pero si en la cepa WT. Con una cruz $\left({ }^{x}\right)$ y en negrita se marcan los péptidos que no pudieron ser identificados en la cepa WT pero sí en la mutante. 
Tabla VI.4 - Cantidades relativas de flagelinas en el filamento subpolar en la cepa WT y flbT:: Km. La Tabla muestra la cantidad de veces que se detectaron péptidos únicos (PSM) de cada flagelina subpolar para la cepa WT y flbT::Km. A su vez, se muestran los porcentajes de cada una de las flagelinas con respecto al total de los péptidos detectados en cada cepa.

\begin{tabular}{|lrrrrr|}
\hline & FliC1 & FliC2 & FliC3 & FliC4 & Totales \\
\hline PSM WT & 64 & 16 & 47 & 180 & 307 \\
\hline PSM flbT::Km & 46 & 36 & 19 & 141 & 242 \\
\hline (\%)PSM FliCX/ Totales WT & $21 \%$ & $5 \%$ & $15 \%$ & $59 \%$ & \\
\hline (\%)PSM FliCX/Totales flbT::Km & $19 \%$ & $15 \%$ & $8 \%$ & $58 \%$ & \\
\hline
\end{tabular}

De los tres transcriptos de flagelinas que mostraron regulación a través de FlbT, sólo FliC2 correlacionó, el aumento de ARNm con una mayor proporción de esta flagelina particular en la constitución del filamento (Tablas VI.2 y VI.4).

Si bien esta metodología nos permitió tener una idea de cuál sería la proporción de cada una de las flagelinas presentes en el filamento de cada cepa, el resultado obtenido no resulta concluyente. En los casos donde se detectaron menores cantidades de flagelinas (para el caso de la cepa WT péptidos de FliC2 y para el caso de la cepa $f l b T:: K m$ péptidos de FliC3) existieron algunos péptidos únicos que no pudieron ser identificados (Tabla VI.3), lo que nos indica que los péptidos únicos de cada flagelina no fueron detectados en iguales proporciones. Esto se debe a que la identificación de cada péptido en el equipo utilizado depende de sus características fisicoquímicas. Para lograr una cuantificación más precisa del conteindo de falgelinas en la composición del falgelo planteamos, en un futuro, modificar levemente el experimento. Dentro de las modificaciones, se intentarán identificar aquellos péptidos únicos que respondan a una diferencia de concentración de manera que sirva como péptido patrón. Una vez establecidos estos péptidos se realizarán nuevamente las medidas correspondientes. Esta variación en el método de cuantificación no pudo realizarse hasta el momento por cuestiones de tiempo y financiamiento.

\section{VI.3.5 Posible rol de FlbTs en la regulación de otros transcriptos independientes de los sistemas flagelares}

\section{Efecto de FlaFs y FlbTs sobre la producción de EPS}

Como mencionamos anteriormente, la mutación de flbT en $C$. crescentus no genera simplemente un defecto de la cepa mutante en su capacidad de formar un filamento funcional, sino que se encuentra involucrado en otros procesos como son la quimiotaxis, la sensibilidad al fago $\varnothing$ Cbk y en la integridad de la membrana (Schoenlein y Ely., 1989; Schoenlein et al., 1992).

Cuando observamos las cepas mutantes en los reguladores de clase III en placas YEM con Rojo Congo encontramos diferencias fenotípicas en las colonias. El mutante $f l b T:: \mathrm{Km}$ presentó colonias mucosas y su capacidad de unir el colorante fue menor que la cepa WT (Figura VI.8-A). Para confirmar si efectivamente el mutante flbT::Km poseía 
aumentada su capacidad de sintetizar EPS, realizamos un ensayo de cuantificación de azúcares reductores en fase estacionaria. Así, la cepa flbT::Km y el doble mutante $\Delta$ fla $F$ $f l b T:: \mathrm{Km}$ fueron capaces de producir mayor cantidad de EPS en medio PSY-ara (20\% y $30 \%$ más producción comparado con la cepa WT), mientras que la cepa $\Delta$ flaF sintetizó $16 \%$ menos EPS comparado con la cepa WT (Figura VI.8-B).

A

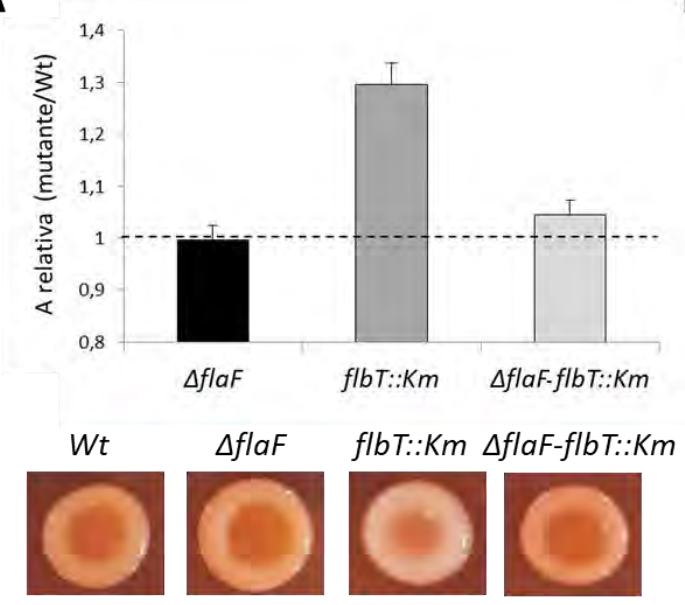

B

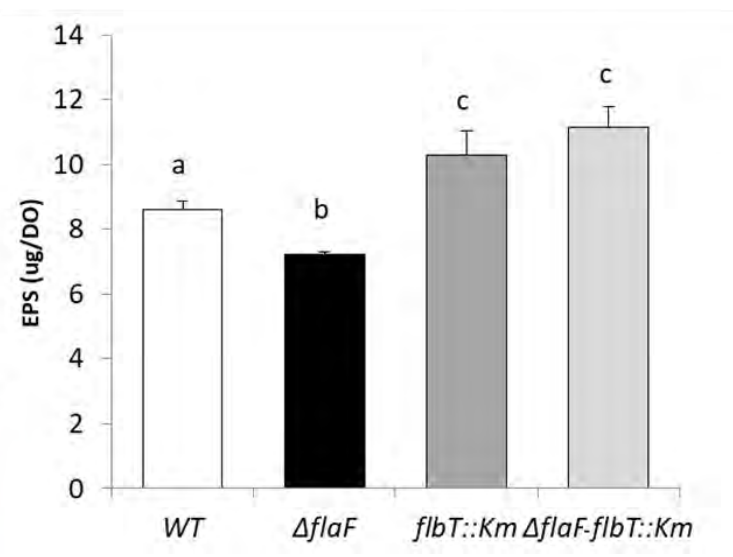

Figura VI.8 - Producción de EPS en los mutantes de $B$. diazoefficiens en flaFy flbT. A. Ensayo de unión a Rojo Congo de los mutantes $\triangle$ flaF y flbT::Km y doble mutante referidos a la cepa WT. Las medidas fueron realizadas por triplicado. Las fotografías muestran las colonias crecidas en placas YEM con el colorante. B. Cuantificación del EPS producido en fase estacionaria de crecimiento en medio líquido PSY-ara. El análisis estadístico fue realizado sobre tres réplicas biológicas con tres réplicas técnicas utilizando ANOVA con $p=0,05$.

\section{Posibles genes target de FlbTs}

Dado que FlbT se une a la región $5^{\prime}$ no traducida (5'UTR) de los transcriptos de las flagelinas cambiando su conformación y ocultando el sitio de unión a ribosomas (Anderson y Gober, 2000) en C. crescentus, realizamos modelados en Mfold de las regiones $5^{\prime}$ UTR de las cuatro flagelinas subpolares de $B$. diazoefficiens USDA 110 . A partir de este análisis, encontramos tres posibles estructuras secundarias para flic1 (la que escapa la cascada de regulación), cuatro para flic2, una única conformación para flic3 y cinco conformaciones para flic4. Todas ellas presentaron un valor de $\Delta G$ similar (que varió entre -41 y -28, ver Anexo Figura AVI.2). Dado que esta información no fue suficiente para identificar algún posible patrón estructural diferencial entre los ARNm de los genes flic1 y flic234, decidimos buscar si existía una secuencia consenso en la región 5'UTR única para los tres genes de aquellas flagelinas reguladas (flic234), y que a su vez no se encontrara presente en flic1. Mediante un alineamiento entre los inicios de la transcripción y el codón de inicio de la traducción, encontramos la secuencia conservada CCAGAAGGGTAA (Figura VI.9). 
Alineamiento 1

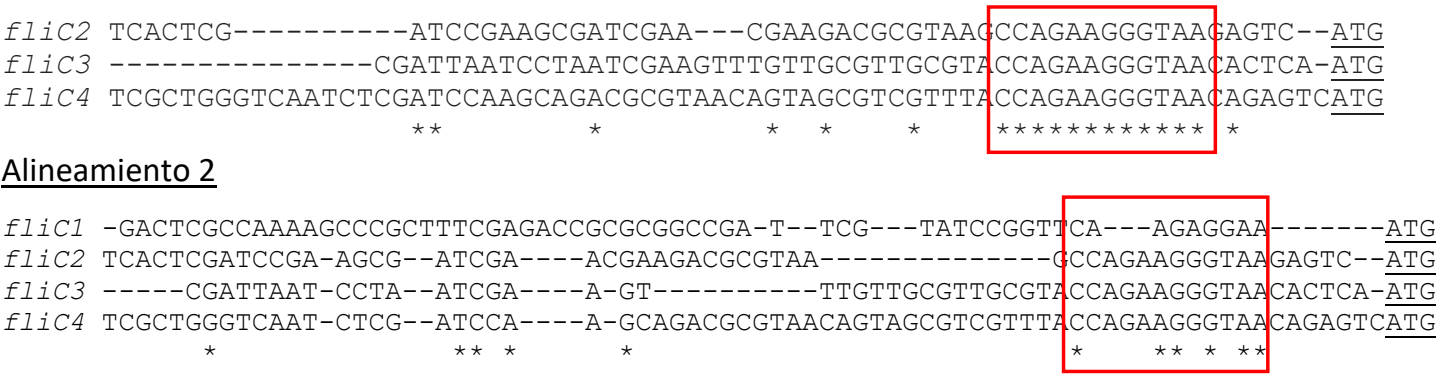

Figura VI.9 - Alineamientos de las regiones $5^{\prime}$ no traducidas (5'UTR) de los genes que codifican las flagelinas subpolares. El primer alineamiento fue realizado utilizando la secuencia $5^{\prime}$ UTR de los tres genes que codifican flagelinas subpolares con mayor porcentaje de similitud. El recuadro rojo muestra la secuencia consenso conservada entre ellas. El segundo alineamiento se realizó con las regiones 5'UTR de las cuatro copias.

Para averiguar si la secuencia consenso encontrada sobre la región 5'UTR de las flagelinas, también se encuentra en algún otro gen (como por ejemplo alguno relacionado con la síntesis de EPS), realizamos una búsqueda de esta secuencia consenso sobre el genoma de $B$. diazoefficiens a través del servidor MAST. La secuencia fue encontrada en tres genes (excluyendo los tres de las flagelinas) aunque la misma no fue identificada en regiones 5'UTR de los mismos. Identificamos el gen bll4288 (que codifica un regulador de respuesta de sistema de dos componentes perteneciente a la Superfamilia CheY), el gen blr0540 (que codifica TypA o BipA: GTPasa de membrana involucrada en respuesta a estrés) y el gen bll6450 (que codifica una proteína de transporte periplasmático tipo $A B C$ de nitrato/ sulfonato/ bicarbonato), pero ninguno de ellos se encontró directamente relacionado con la producción de EPS.

Para analizar si FlbTs estaría regulando la traducción de alguna de estas proteínas mencionadas previamente, observamos la integridad de la membrana utilizando el detergente SDS. Esto fue realizado dado que BipA (cuyo transcripto contendría la secuencia consenso encontrada para $\mathrm{FlbT}_{\mathrm{S}}$ ) es importante para la respuesta a diferentes estreses entre los que se encuentra la resistencia a detergentes (Starosta et al., 2014). Además, en $C$. crescentus también se encuentra reportado que mutantes en flbT poseen afectada la integridad de la membrana (Schoenlein y Ely 1989).

Si bien el ensayo de sensibilidad a SDS fue realizado una sola vez, la cepa flbT::Km fue capaz de resistir más la acción del detergente comparado con la cepa WT (Figura VI.10). 

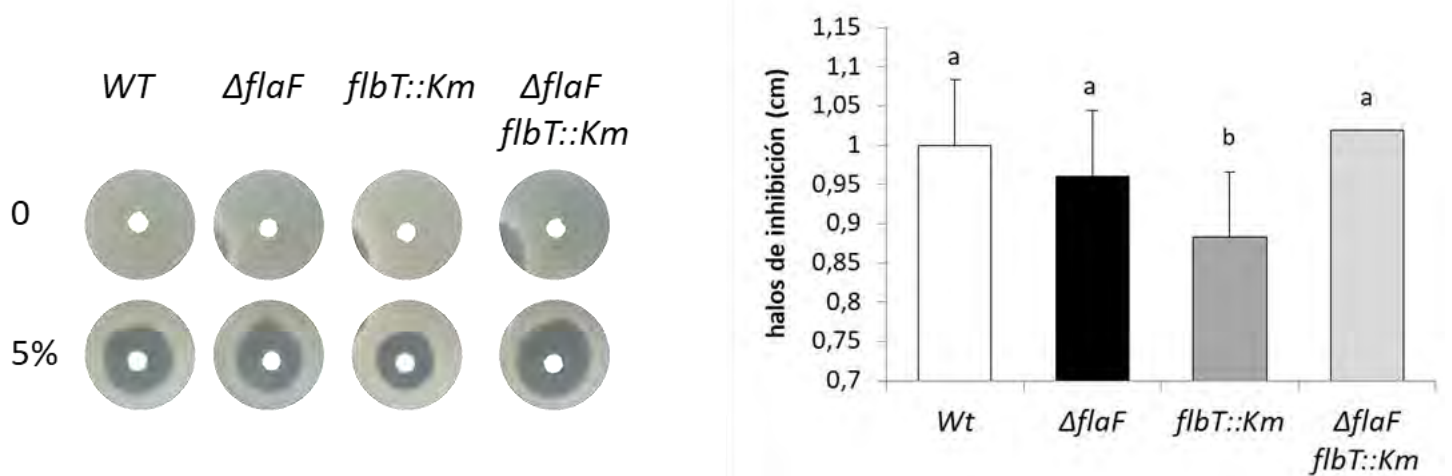

Figura VI.10 - Halos de inhibición de crecimiento en placas de Petri utilizando discos de papel embebidos con SDS. A la izquierda se muestra una foto a tiempo final de los discos sin detergente (arriba) y con SDS 5\% (abajo). A la derecha se muestran los promedios de los halos de inhibición.

\section{VI.4 Conclusión y perspectivas}

A raíz de los resultados mostrados en este Capítulo hemos podido determinar que $\mathrm{FlaF}_{\mathrm{S}}$ actúa positivamente sobre los niveles de ARNm de las tres flagelinas flic234, siendo además necesaria para la correcta síntesis del filamento. Por otro lado, encontramos que $\mathrm{FlbT}_{S}$ regula negativamente los niveles de $\mathrm{ARNm}$ de las flagelinas flic234. Los niveles de ARNm de flic1 en cambio, no responden a ninguno de estos dos reguladores. Esta flagelina podría encontrarse sólo bajo la acción de CtrA, como ocurre con algunas flagelinas en el modelo de $C$. crescentus (Ardissone y Viollier, 2015).

De los dos modelos regulatorios estudiados hasta el momento, parecería que $\mathrm{FlaF}_{\mathrm{S}}$ y $\mathrm{FlbT}_{\mathrm{S}}$ actúan de manera similar al modelo de C. crescentus (Smith y Hoover 2009). Una diferencia importante con este modelo es que la mutación de $\mathrm{FlbT}_{\mathrm{S}}$ en $B$. diazoefficiens aún permite la formación de un flagelo funcional. El filamento podría tener modificada la proporción de flagelinas que lo conforman, aunque este cambio no afectaría su síntesis y funcionalidad. Para verificar esta hipótesis es necesario analizar nuevamente las flagelinas que conforman el filamento subpolar con la nueva metodología propuesta.

Por otro lado, el sistema $\mathrm{FlaF}_{\mathrm{L}}$ y $\mathrm{FlbT}_{\mathrm{L}}$ en $B$. diazoefficiens parecería asemejarse al sistema descripto en B. melitensis (Mongiardini et al., 2017). Un dato que soporta esta hipótesis es que la deleción de $\mathrm{FlaF}_{\mathrm{S}}$ no genera un filamento funcional y por ende $\mathrm{FlaF}_{\mathrm{L}}$ no sería capaz de reemplazar la función de $\mathrm{FlaF}_{\mathrm{s}}$. Este mismo efecto se observa cuando se deleciona $\mathrm{FlbT}_{L}$, y la falta de flagelos laterales no puede ser evitada por la presencia de FlbT $_{S}$ (Mongiardini et al., 2017).

Para continuar la caracterización del mecanismo de acción de $\mathrm{FlbT}_{\mathrm{S}}$ y $\mathrm{FlaF}_{\mathrm{S}}$ sobre los niveles de ARNm de las flagelinas nos resta realizar ensayos de retardo utilizando diferentes fragmentos de ARN de la región 5' no traducida para comprobar 
efectivamente que estas proteínas son capaces de unirse a los ARNm, y determinar si la secuencia conservada CCAGAAGGGTAA es efectivamente necesaria para el reconocimiento de estos reguladores.

$\mathrm{FlbT}_{\mathrm{S}}$ además podría estar involucrada en la regulación de otros ARNm además de las flagelinas, afectando otros procesos celulares como por ejemplo la producción de EPS, la integridad de la membrana e incluso participando de la regulación cruzada entre los dos sistemas flagelares. 


\section{VI.5 Anexo}

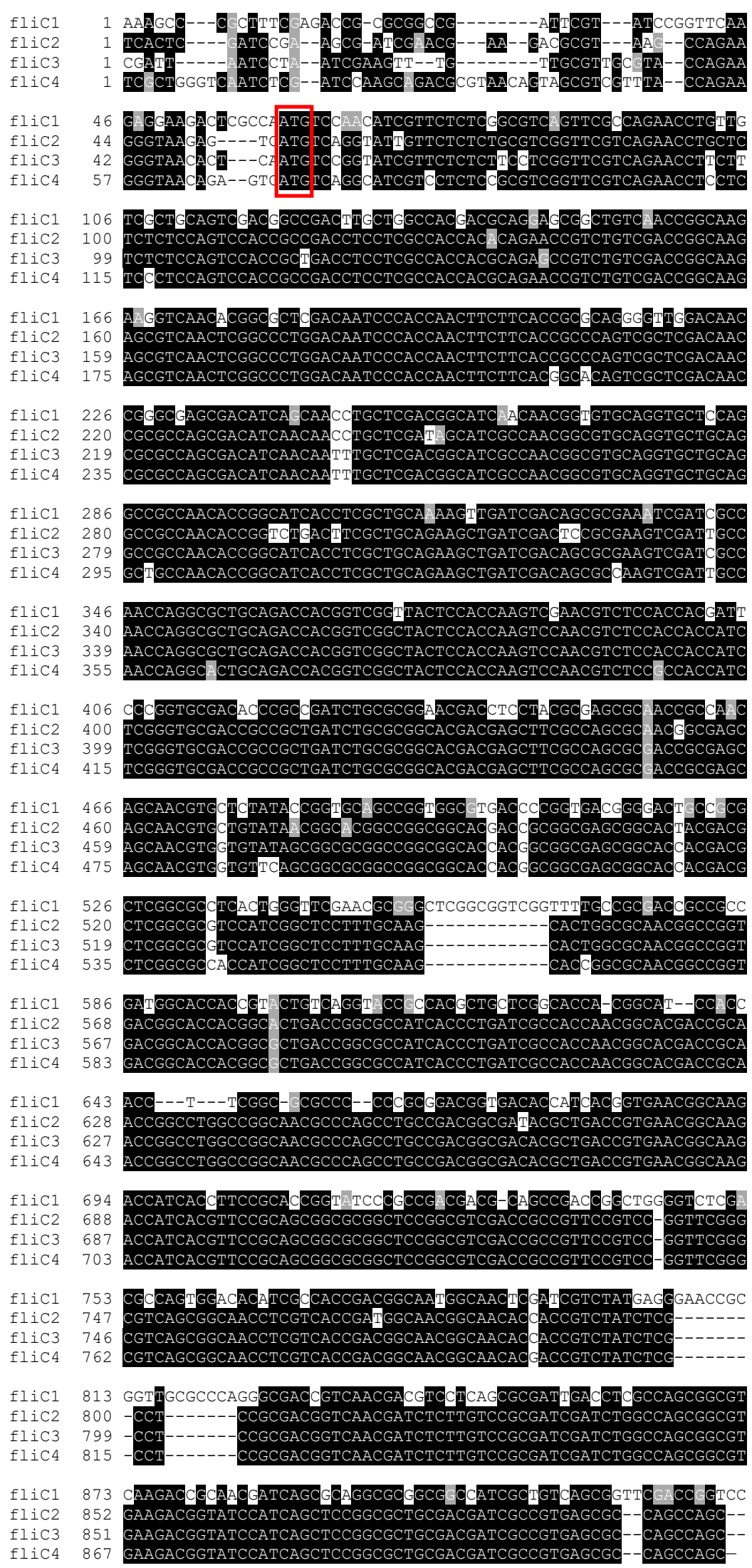




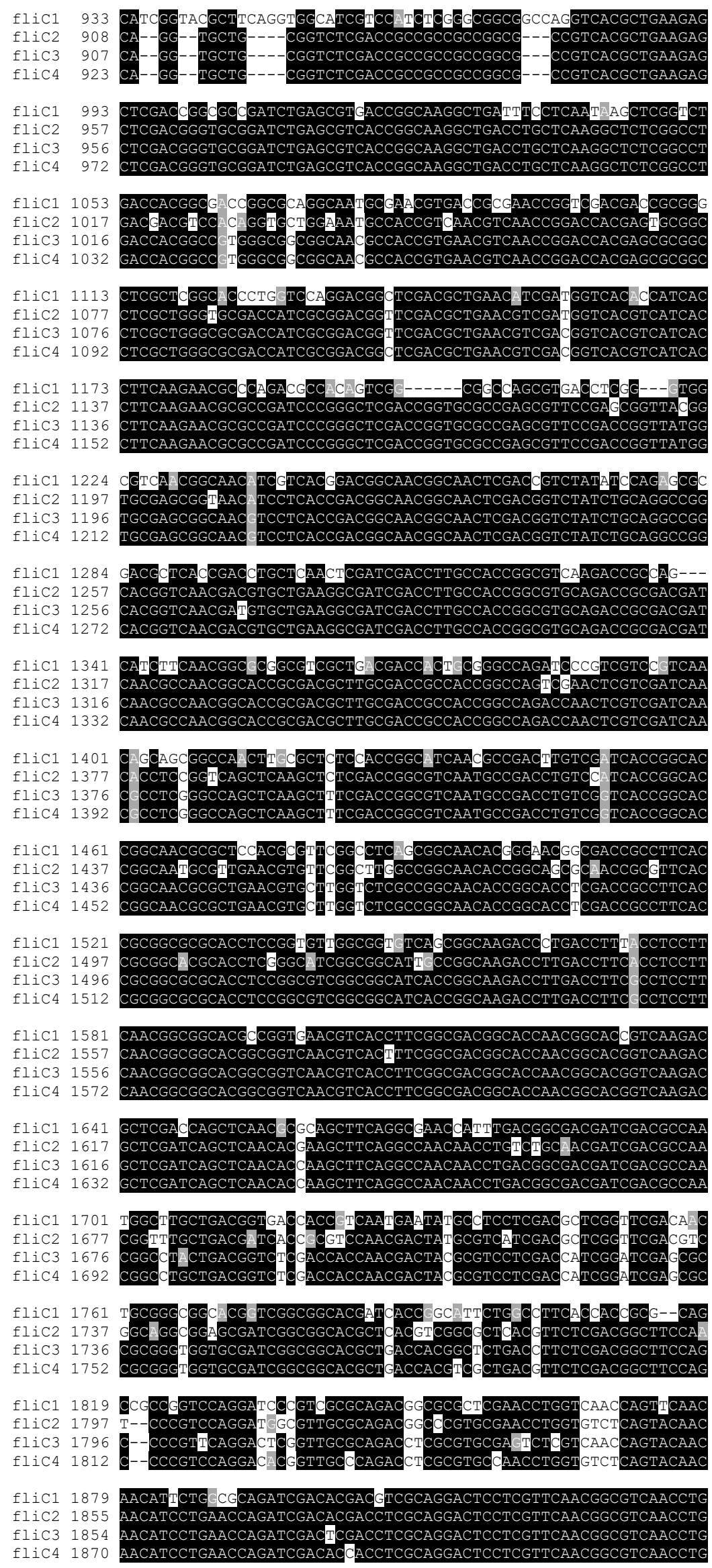




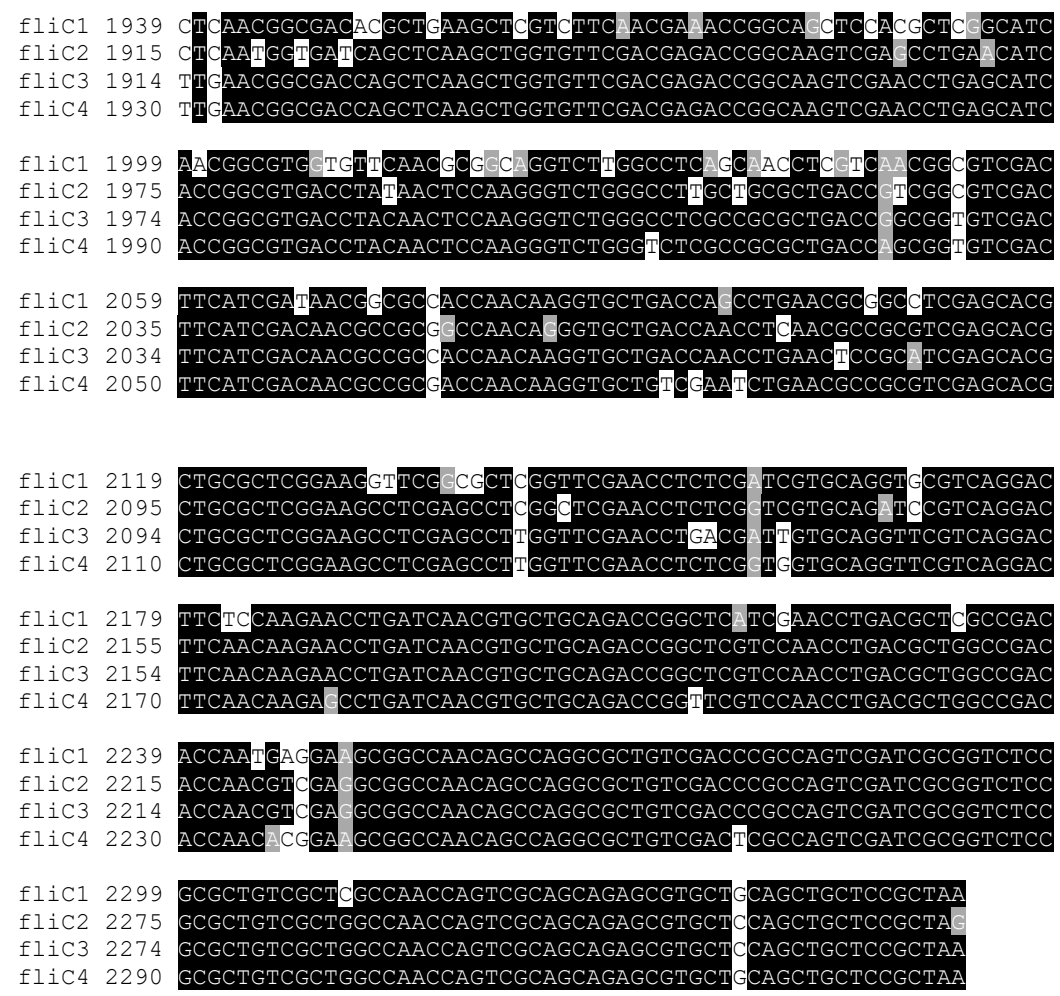

Figura AVI.1 -Alineamiento de las secuencias nucleotídicas de las cuatro flagelinas subpolares de la secuencia codificante y la región $5^{\prime}$ no codificante. En rojo se encuentra marcado el codón de inicio de la secuencia codificante. 
flic1

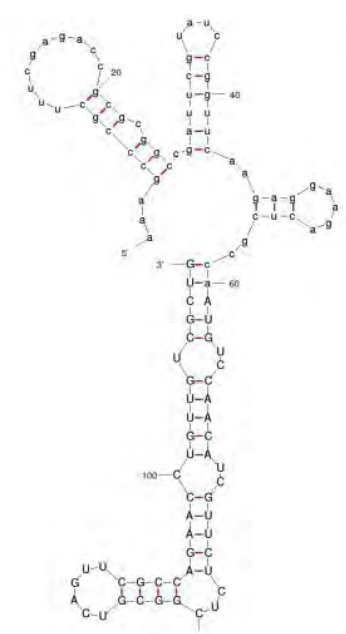

$d G=-34,59$

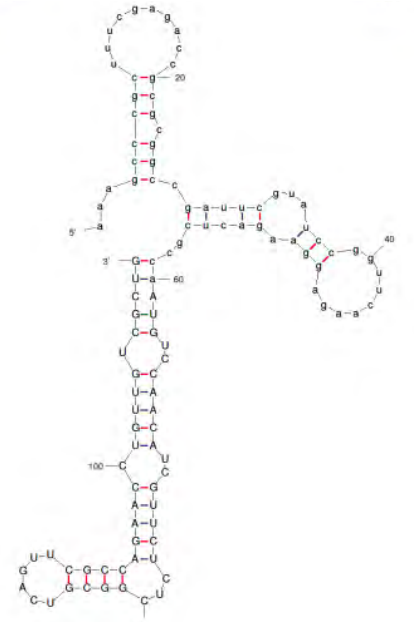

$d G=-34,26$

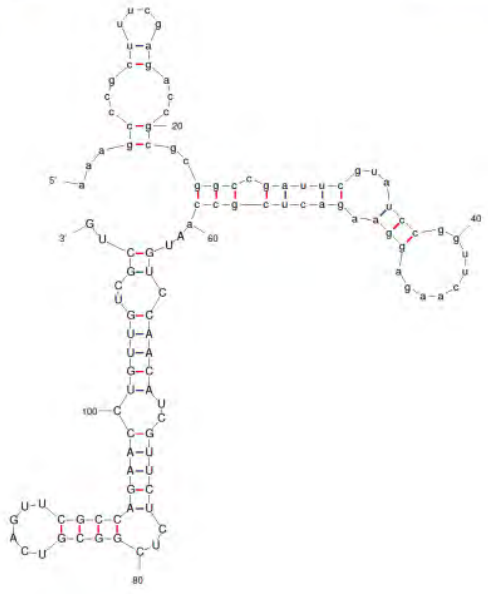

$d G=-33,77$

flic2

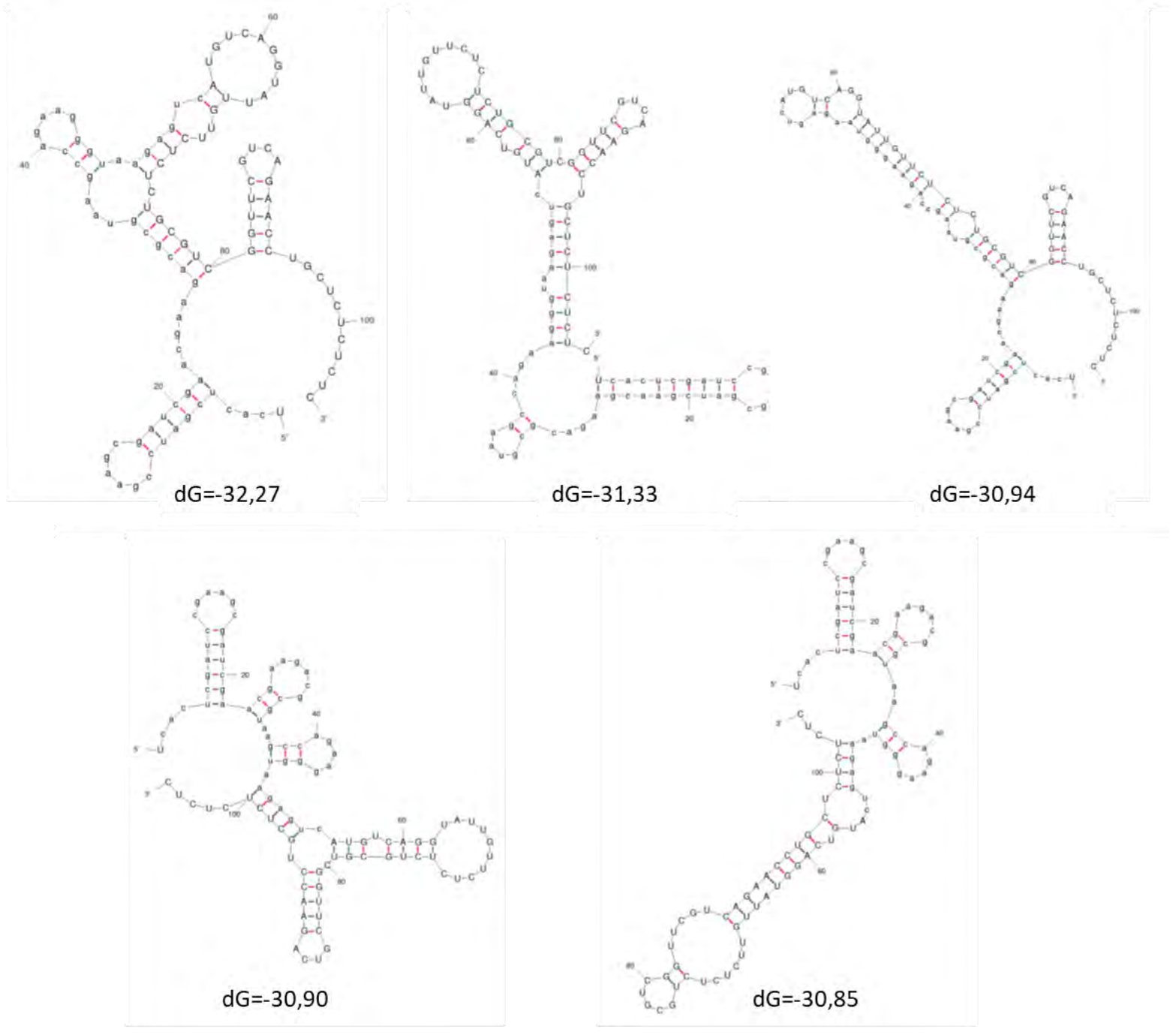


flic3

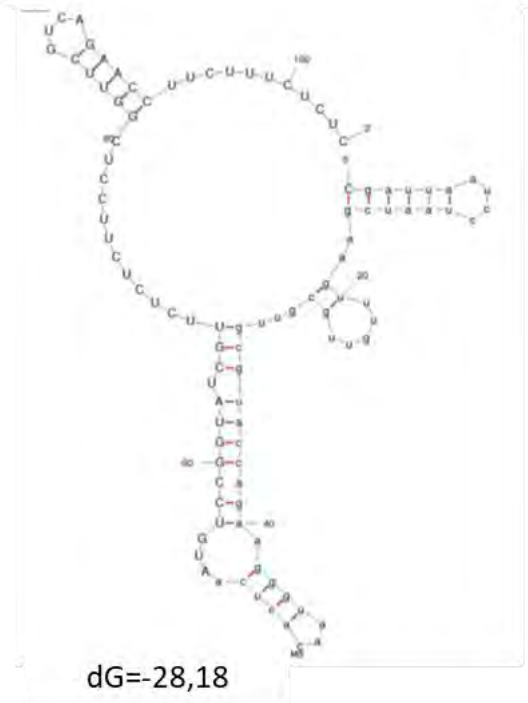

flic4

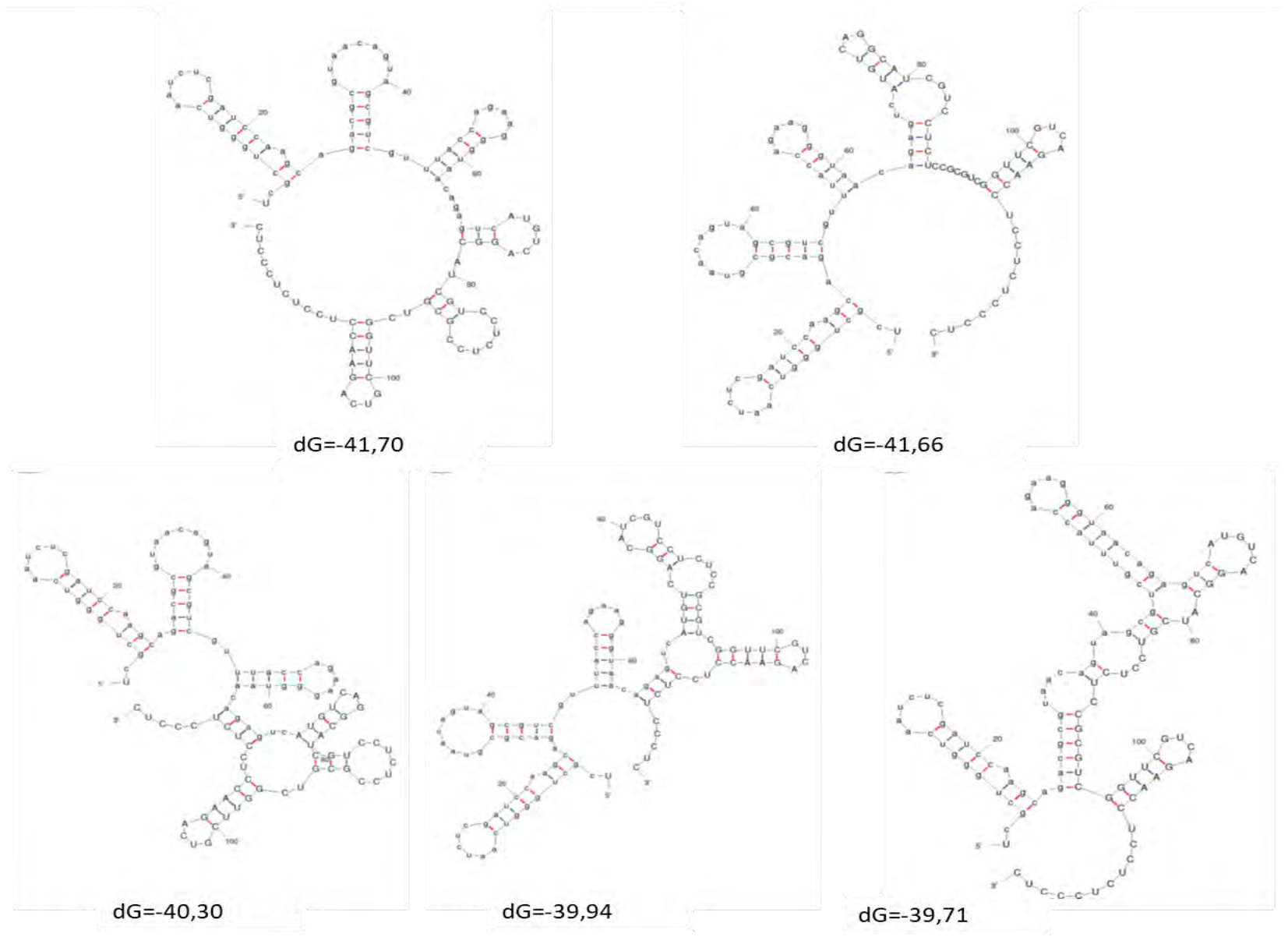

Figura AVI.2 - Predicción de estructura secundaria de las regiones 5'UTR de los genes que codifican flagelinas subpolares. 

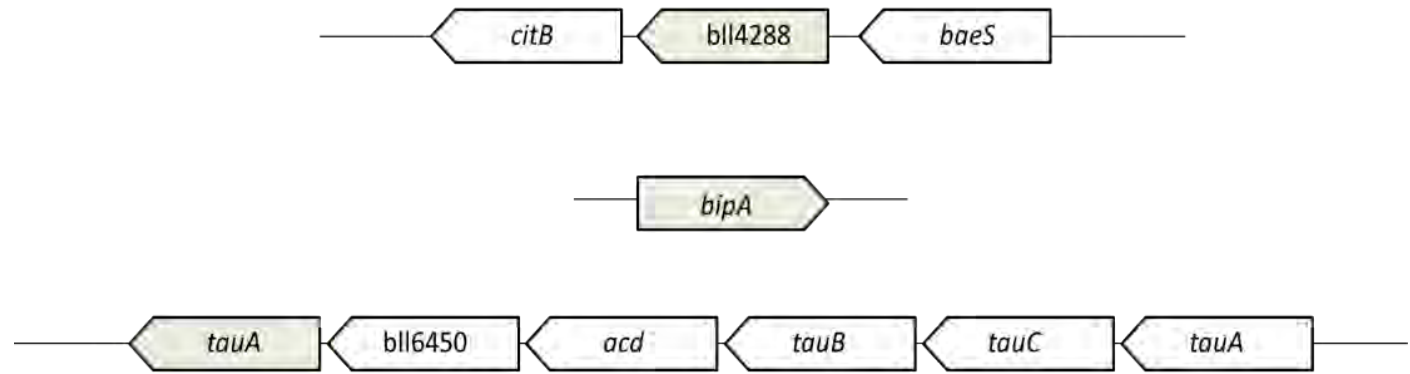

Figura AVI.3 - Organización genómica de los genes que poseen la secuencia consenso CCAGAAGGGTAA. En gris se encuentran resaltados los genes que poseen la secuencia consenso. citB codifica un regulador transcripcional para la fermentación de citrato. bll4288 codifica un regulador de respuesta perteneciente a CheY superfamily. baeS codifica una histidín quinasa multidrug-efflux. bipA codifica una GTPasa que participa de la respuesta a estrés. $\operatorname{tau} A B C$ codifican el sistema de transporte tipo ABC. acd: acetil-CoA deshidrogenasa. 
Capítulo VII: Efectos del c-di-GMP sobre los dos sistemas flagelares de $B$. diazoefficiens

USDA 110 



\section{VII.1 Introducción}

Como mencionamos en la Introducción, el c-di-GMP es una molécula pequeña que actúa como segundo mensajero en la señalización de diversos procesos celulares, entre los que se encuentran la movilidad y la formación de biofilms (Jenal et al., 2017).

Los cambios en la concentración de c-di-GMP modifican considerablemente la capacidad de movimiento de las bacterias. En general, un aumento en la concentración de este segundo mensajero sirve de señal para disminuir la movilidad bacteriana y promover la formación de adhesinas y EPS para la formación de biofilms, favoreciendo el paso al estado de vida sésil (Hengge, 2009). El c-di-GMP es capaz de modular la capacidad de movimiento bacteriano a través de diversos mecanismos: aumentando, disminuyendo o frenando por completo la velocidad de rotación del filamento, o modificando la frecuencia de tumbos para promover cambios de dirección (Blair et al., 2008; Paul et al., 2010; Belas, 2014). Estos efectos son reversibles y le permiten a la bacteria estar preparada en caso de que perciba la necesidad de realizar un cambio al estado de vida sésil o continuar en estado plantónico. El c-di-GMP también influye sobre otros procesos como la regulación de la síntesis flagelar (mediante interacción con reguladores de la cascada de síntesis flagelares) e incluso la eyección del flagelo mediante interacción con proteínas de la estructura (Aldridge y Jenal, 1999; Ozaki et al., 2009; Krasteva et al., 2010; Baraquet y Harwood, 2013). Ejemplos de cada uno de estos mecanismos nombrados fueron detallados en el Capítulo I.5.2.

Además de estar involucrado en la movilidad, el c-di-GMP regula otros procesos muy diversos como el ciclo y desarrollo celular, expresión de factores de virulencia, secreción de sustancias y respuesta a estreses, entre otros (Hengge, 2009; Dahlstrom y O’Toole, 2017). La variedad de procesos en los que participa esta molécula hace que su estudio sea muy complejo. Los rizobios son unas de las bacterias que presentan mayor cantidad y variedad de proteínas involucradas con esta vía de señalización. $E$. meliloti posee 21 proteínas con dominios relacionados con c-di-GMP, mientras que $B$. diazoefficiens posee alrededor de 54 (Gao et al., 2014). A continuación, mostramos un análisis in silico de las proteínas involucradas en este proceso de señalización en $B$. diazoefficiens USDA 110. Además, mediante dos aproximaciones diferentes (aumento de la concentración de c-di-GMP intracelular o mutagénesis sitio-dirigida de genes codificantes de proteínas con actividad DGC o PDE), estudiamos el efecto del c-di-GMP sobre los sistemas flagelares de nuestra especie modelo. 


\section{VII.1.2 Análisis bioinformático de proteínas relacionadas con la vía de señalización a través de c-di-GMP en B. diazoefficiens USDA 110}

Una primera aproximación para la identificación de todas las proteínas relacionadas con la vía de señalización del c-di-GMP fue realizada por Gao y colaboradores (2014) a partir de la búsqueda de proteínas con dominios característicos conservados en seis rizobios diferentes (M. loti, $R$. etli, $R$. leguminosarum, Sinorhizobium fredii, E. meloti y B. diazoefficiens). En dicho trabajo identificaron 54 proteínas relacionadas con la vía de señalización mediada por c-di-GMP, las cuales se listan en la Tabla VII.1 Allí se detallan 12 proteínas DGC que poseen solamente el dominio característico (GGDEF), 23 proteínas que poseen dominios conservados de síntesis (GGDEF) y de degradación (EAL) y que por lo tanto podrían actuar como DGC y/o PDE, 7 proteínas PDE con dominios de degradación de c-di-GMP (4 con el dominio EAL y 3 con HD-GYP) y al menos 12 proteínas efectoras capaces de unir c-di-GMP con dominio PilZ (Gao et al., 2014). Las proteínas con dominios PilZ no son las únicas proteínas efectoras capaces de unir c-di-GMP. Algunas de ellas poseen dominios de síntesis (GGDEF) o de degradación (EAL/HD-GYP) degenerados, otras son capaces de unir c-di-GMP en dominios tipo AAA+ y también se han descripto ARNm riboswitches capaces de responder a este segundo mensajero (Jenal et al., 2017). Esto quiere decir que las proteínas listadas en la Tabla con dominio PilZ no serían las únicas proteínas efectoras involucradas en este proceso de señalización.

A partir del análisis realizado por Gao y col. (2014), se encontraron únicamente cuatro proteínas presentes en B. diazoefficiens (BII5123, Bll1502, Bll2394 y Blr5568) conservadas en los seis rizobios analizados. Esto demuestra que cada uno de estos rizobios posee sus propias proteínas participantes de este proceso de señalización. Por esta razón, nos preguntamos qué sucede con el grado conservación las 54 proteínas relacionadas con la señalización mediada por c-di-GMP en otras cepas relacionadas a B. diazoefficiens USDA 110. Para el análisis elegimos tres cepas de B. diazoefficiens (USDA 110, USDA 122 y SEMIA 5080), dos cepas de B. japonicum (SEMIA 5079 y USDA 6) y una cepa de $B$. elkanii (USDA 76). Así, encontramos que la mayoría de las proteínas se mantienen conservadas con un alto porcentaje de similitud (entre $80 \%-100 \%$ ). Sin embargo, seis de ellas parecen encontrarse solo en $B$. diazoefficiens. De estas seis proteínas encontramos una con dominio GGDEF (Bll6704), cuatro con los dominios GGDEF-EAL (Bll6496, Bll6545, Blr2589, BIr8000) y una con dominio PilZ (Bll6705). Esto podría indicar que existirían proteínas particulares participantes del proceso de señalización mediado por c-di-GMP en cada género de Bradyrhizobium. Para confirmar esta hipótesis resulta necesario extender el análisis con otras cepas de Bradyrhizobium. 
Tabla VII.1 - Grado de conservación de proteínas de la vía de señalización de C-di-GMP de Bradyrhizobium y en otras especies de rizobios. La Tabla muestra las proteínas que poseen dominios conservados DGC, PDE y proteínas efectoras en B. diazoefficiens USDA 110 y su porcentaje de similitud aminoacídica con otras cepas y especies en escala de grises (99-100 \% 98-90 \% 89-80 \% 79-65 $\%)$.

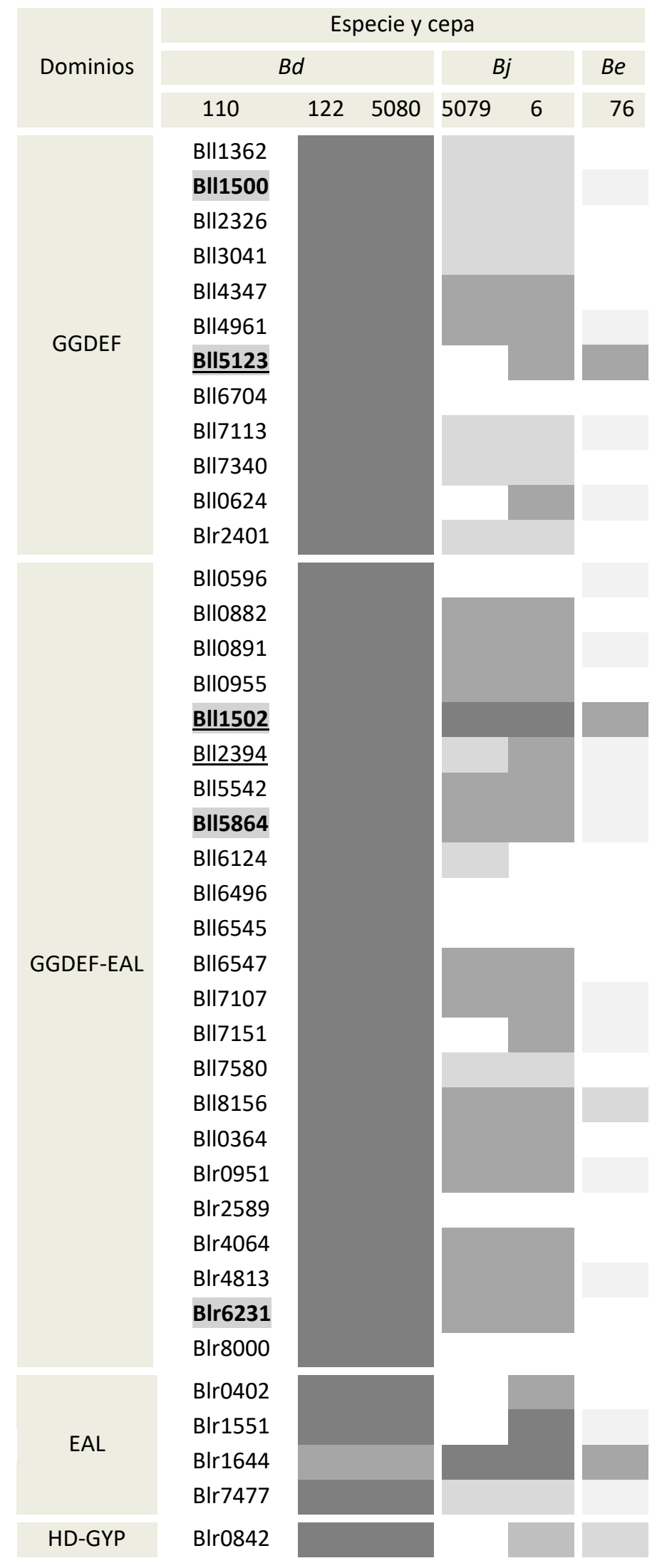




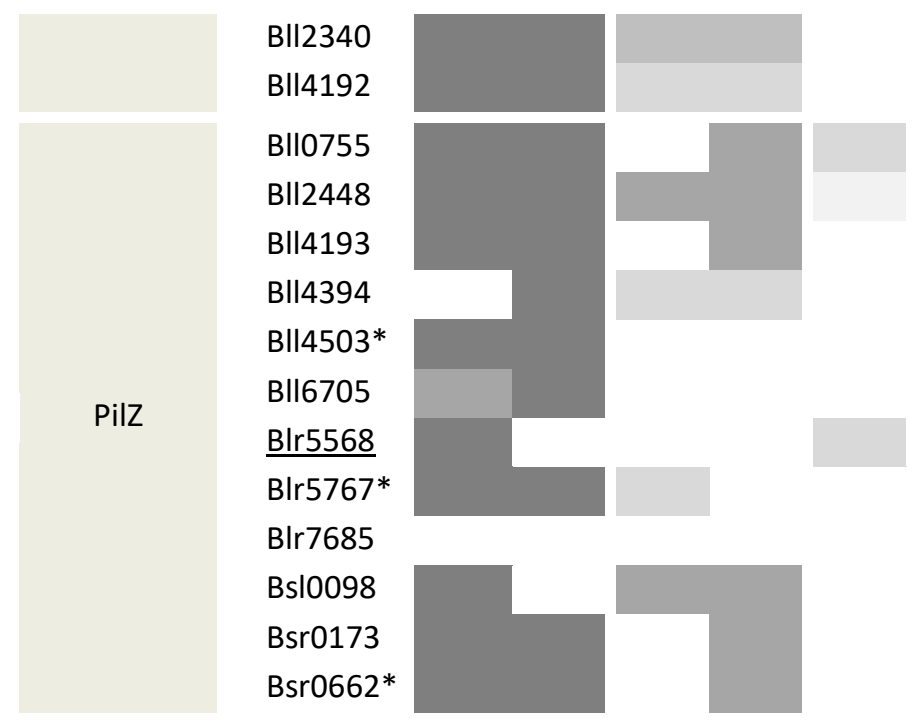

Abreviaturas: B. diazoefficiens (Bd), B. japonicum (Bj), B. elkanii (Be).

Las proteínas resaltadas en negrita indican que existen mutantes de $B$. diazoefficiens en nuestro laboratorio que no las sintetizan. Las proteínas que se encuentran conservadas en Bradyrhizobium y en algunos de los rizobios estudiados por Gao se encuentran subrayados. Con asterisco se marcan los genes con secuencia PilZ ambigua.

Dada la redundancia de proteínas relacionadas con la vía de señalización mediada por c-di-GMP y la capacidad de las mismas de actuar como pares DGC-PDE (o en cascada) sobre un mismo pool de c-di-GMP (Lindenberg et al., 2013), el abordaje mediante mutagénesis resulta complejo (Boehm et al., 2010; Newell et al., 2011; Schäper et al., 2016). En algunos microorganismos se ha desarrollado una estrategia para estudiar la vía de señalización de c-di-GMP que consiste en la obtención de un mutante múltiple en todas las DGC, que suelen denominarse DGC cero (DGCO). De esta manera, se logra generar una herramienta sumamente útil para estudiar la expresión individual de cada una de las proteínas con posible actividad DGC y su efecto neto en determinados fenotipos (Newell et al., 2011; Castro et al., 2015; Schäper et al., 2016). Este mismo abordaje en $B$. diazoefficiens insumiría gran cantidad de tiempo y recursos, dada la gran cantidad de proteínas con posible actividad DGC (35 en total). Sin embargo, en bibliografía también se encuentran estudios mediante mutagénesis de ciertos genes individuales que codifican una DGC O PDE, los cuales presentaron fenotipos de menor movilidad o formación de biofilms (Boehm et al., 2010; Petersen et al., 2011). Debido a ello, en el laboratorio hemos comenzado a realizar mutantes en algunas proteínas que podrían estar involucradas en el proceso de señalización mediada por c-di-GMP en $B$. diazoefficiens y que podrían estar afectando la movilidad dependiente de flagelos (marcados en negrita en la Tabla VII.1).

Para comenzar el abordaje del estudio del c-di-GMP sobre la movilidad en $B$. diazoefficiens decidimos analizar el efecto que causa el aumento de la cantidad total de c-di-GMP intracelular mediante la expresión heteróloga de ciclasas descriptas en otros microorganismos. 


\section{VII.2 Expresión heteróloga de ciclasas}

Para comenzar este estudio, realizamos la expresión de dos DGC heterólogas conocidas. Estas enzimas tienen funciones relacionadas con la modulación de la movilidad y la formación de biofilms en los microorganismos donde fueron descriptas. Una de ellas es una ciclasa tipo TpbB (PA1120) de $P$. aeruginosa que, luego de ser fosforilada, aumenta los niveles de c-di-GMP generando mayor producción de EPS, mayor número de adhesinas e inhibiendo la movilidad por swarming (Ueda y Wood, 2009). La copia del gen $t p b B$ fue cedida por el Dr. Federico Sisti (miembro del laboratorio VacSal de nuestro Instituto). Otra de las ciclasas que utilizamos fue la ciclasa modificada PleD* de C. crescentus. Esta proteína es importante tanto para la progresión del ciclo celular como para la diferenciación morfológica en esta bacteria (Hecht y Newton 1995, Jenal et al., 2017). En C. crescentus, la actividad de PleD se encuentra activada o reprimida por fosforilación en cada polo bacteriano, generando zonas con diferentes concentraciones de c-di-GMP durante la división asimétrica. Esta señal es fundamental para lograr la eyección del flagelo y la formación del stalk, el cual le permite adherirse a la superficie e iniciar un nuevo proceso de división. Esta misma señal, pero de manera inversa se produce en la célula hija, en cuyo polo se origina la formación del flagelo antes de finalizar la división celular (Jenal et al., 2017). En el laboratorio contamos con un plásmido cedido por el grupo del Dr. Juan Sanjuan de la Estación Experimental del Zaidín (Granada, España) y utilizado por este grupo en la caracterización de diversas especies bacterianas (Pérez Mendoza et al., 2014; RomeroJiménez et al., 2015). Se sabe que su sobreexpresión aumenta la producción de EPS, induce a la formación de biofilms, disminuye la movilidad y genera defectos en la FBN (Pérez Mendoza et al., 2014; Romero-Jiménez et al., 2015). Este vector lleva clonado una copia del gen ple $D^{*}$ de $C$. crescentus que posee su actividad aumentada dado que no requiere ser fosforilada para su activación (Paul et al., 2004).

\section{VII.2.1 Construcción de cepas que expresan PleD* y TpbB}

Para comenzar con la expresión de las ciclasas mencionadas en B. diazoefficiens, se clonaron los genes heterólogos ( $t p b B$ y $p l e D^{*}$ ) en un vector replicativo en este rizobio. Elegimos para ello el vector pFAJ1708, el cual es replicativo y estable, aún en ausencia de antibiótico. El gen $t p b B$ fue clonado utilizando las enzimas BamHI-Sacl presentes en los primers diseñados para tal fin obteniendo el plásmido pFAJ::tpbB. Para la expresión de pleD*, el gen fue subclonado a partir del plásmido pJBTc19::pleD* (Pérez-Mendoza et al., 2014) utilizando los sitios de restricción Xbal y EcoRI. Ambas construcciones fueron chequeadas por digestión y posterior secuenciación. Cada plásmido fue transferido separadamente por conjugación a la cepa WT, dando como resultado las cepas $B d$-pFAJ::tpbB y $B d$-pFAJ::pleD* (Figura VII.1 y VII.2). 


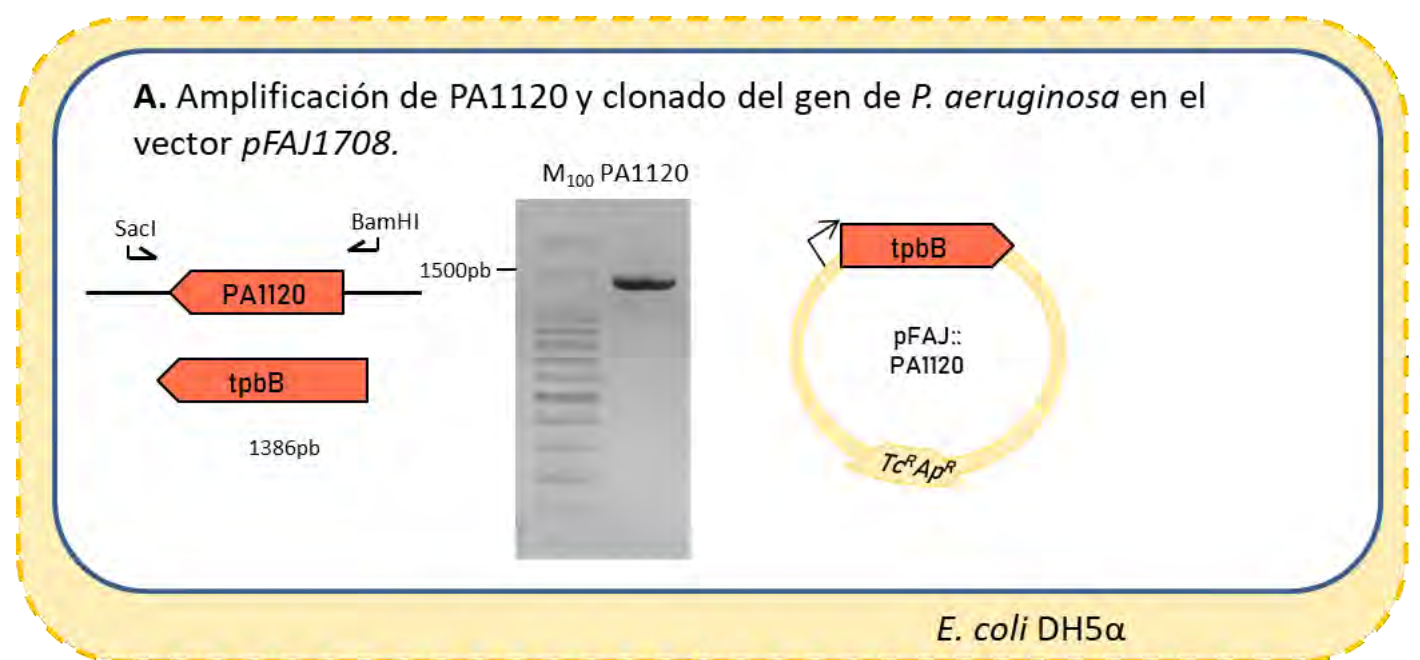

B. Chequeo de introducción del plásmido en B. diazoefficiens por resistencia $A p$ y Tc y PCR con primers específicos y del vector.
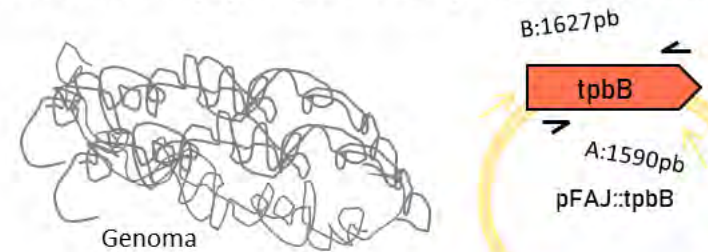

$T^{R} A p^{p}$

Vector replicativo en $B$. diazoefficiens

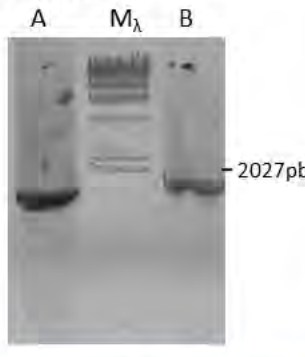

B. diazoefficiens USDA 110

Figura VII.1 - Esquema del clonado y selección de la cepa de $B$. diazoefficiens que expresa $t p b B$ de $P$. aeruginosa. El gráfico con el recuadro amarillo muestra el clonado para la obtención del plásmido pFAJ::tpbB y el gráfico con el recuadro verde muestra el chequeo para la obtención de la cepa $B d$-pFAJ::tpbB. PA1120 representa el gen $t p b B$ de $P$. aeruginosa. En los geles de agarosa, $\mathrm{M}_{100}$ y $\mathrm{M}_{\lambda}$, indican los marcadores de peso molecular de $100 \mathrm{pb}$ y $\lambda$-Hindlll, respectivamente. 
A. Liberación del gen pleD* de C. crescentus del plásmido pJBTc19::pleD* y subclonado en el vector $p F A J 1708$ utilizando las enzimas Xbal-EcoRI.
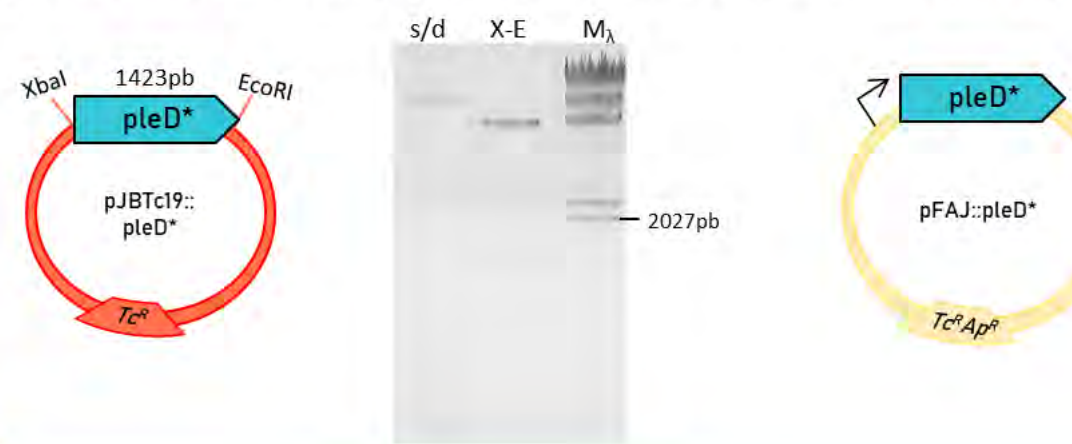

E. coli $\mathrm{DH} 5 \alpha$

B. Chequeo de introducción del plásmido en $B$. diazoefficiens por resistencia Ap y Tc.
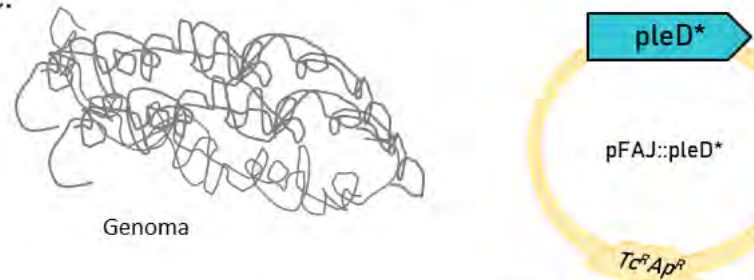

Vector replicativo en $B$. diazoefficiens

B. diazoefficiens USDA 110

Figura VII.2 - Esquema del clonado y selección de la cepa de $B$. diazoefficiens que expresa $p / e D^{*}$ de $C$. crescentus. El gráfico con el recuadro amarillo muestra el clonado para la obtención del plásmido pFAJ::pleD* y el gráfico con el recuadro verde muestra el chequeo para la obtención de la cepa $B d$-pFAJ::ple $D^{*}$. En el gel de agarosa, $\mathrm{M}_{\lambda}$, indica el marcador de peso molecular $\lambda$ HindIII. las digestiones se indican con las iniciales de las enzimas de restricción utilizadas y s/d indica el control de plásmido sin digerir.

\section{VII.2.2 Efecto de la expresión de ciclasas heterólogas sobre el crecimiento en B. diazoefficiens}

Para comenzar la caracterización de las cepas de $B$. diazoefficiens que expresan la ciclasa TpbB de $P$. aeruginosa y la ciclasa PleD* de $C$. crescentus, analizamos el crecimiento en el medio líquido AG y lo comparamos con la cepa WT que lleva el plásmido vacío ( $B d$-pFAJ) para descartar efectos relacionados a la síntesis y replicación del plásmido. En el primer experimento llevado a cabo, observamos que la cepa $B d$ pFAJ::ple ${ }^{*}$, crecía con dificultad en fase exponencial, pero alcanzando la misma densidad óptica en estado estacionario con respecto a la cepa $B d$-pFAJ::tpbB y $B d$-pFAJ (Figura VII.3 y Figura VII.4). Sin embargo, cuando realizamos los recuentos de unidades 
formadoras de colonias (UFC), detectamos que la cepa que expresa PleD* comienza a morir a partir de $\mathrm{DO}_{500}=1$ (estadio de fase exponencial de acuerdo a la medida de densidad óptica (Figura VII.4-B)). Los recuentos de UFC fueron realizados en placas réplica con y sin antibiótico para corroborar si el plásmido se mantenía estable aún en ausencia de presión de selección. Existen reportes donde la expresión de PleD* utilizando la construcción pJBTc19::pleD* en diferentes microorganismos no suele ser estable (Pérez Mendoza et al., 2014). En este caso, no detectamos la pérdida del plásmido pFAJ::pleD* (Ver Figura VII.4-B).

Dado que la cepa $B d$-pFAJ::pleD* mostró un aumento en la $\mathrm{DO}_{500}$ aunque las bacterias habían dejado de dividirse ( $\left(\mathrm{DO}_{500}\right.$ mayor o igual a 1$)$, decidimos realizar un análisis de la morfología celular de estas bacterias. Así, la observación de bacterias al microscopio óptico (crecidas hasta alcanzar una $\mathrm{DO}_{500}=0,7$ ) nos reveló que los bacilos de la cepa $B d$-pFAJ::ple $D^{*}$ fueron más largos que los de la cepa $B d$-pFAJ (Figura VII.4-C). Este alargamiento, y no un mayor número de células, podría explicar el aumento de la densidad óptica en fase exponencial.

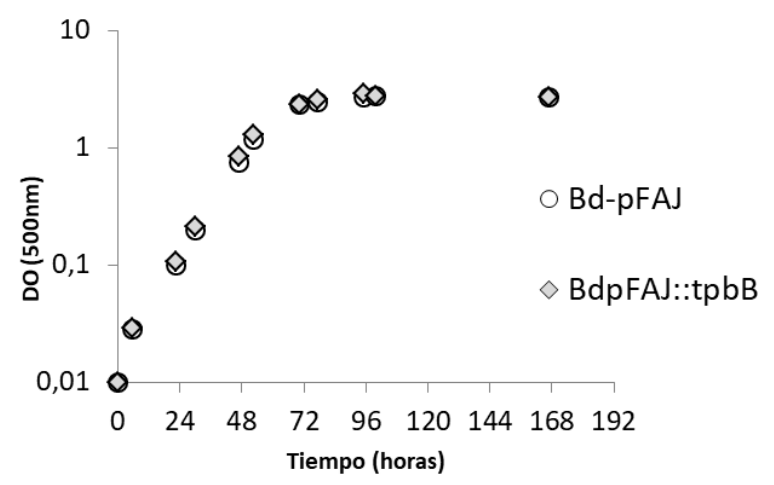

Figura VII.3 - Cinética de crecimiento de la cepa de $B$. diazoefficiens que expresa $t p b B$. Medida de la densidad óptica $(500 \mathrm{~nm})$ de la cepa que lleva el plásmido vacío $(B d-\mathrm{pFAJ})$ y la cepa que expresa $\mathrm{TpbB}$ de $P$. aeruginosa $(B d-$ pFAJ::tpbB) en medio AG. 
A

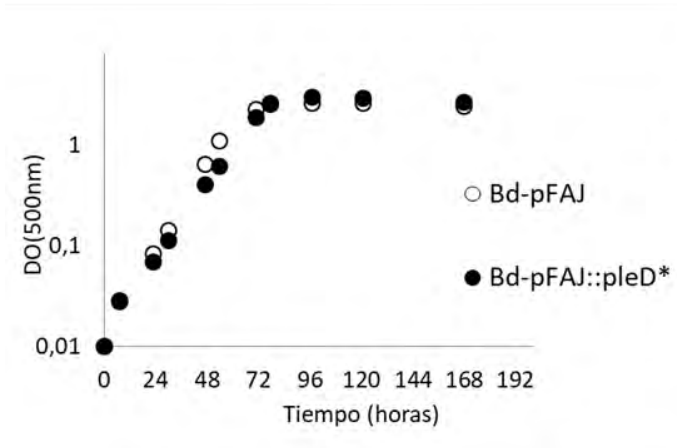

$\mathrm{C}$
B

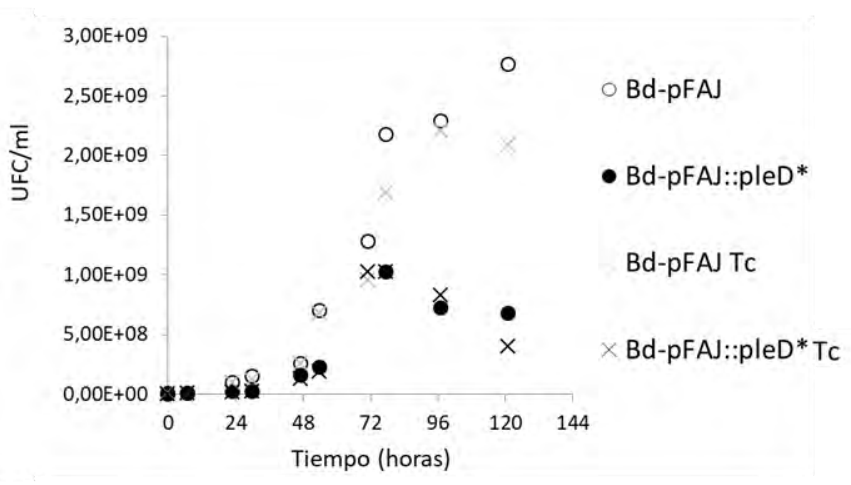

Bd- pFAJ

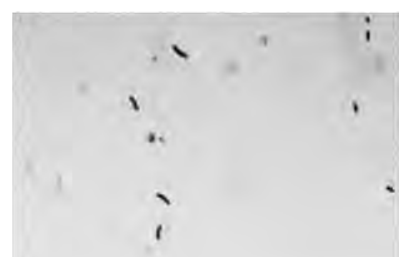

Bd- pFAJ::pleD*

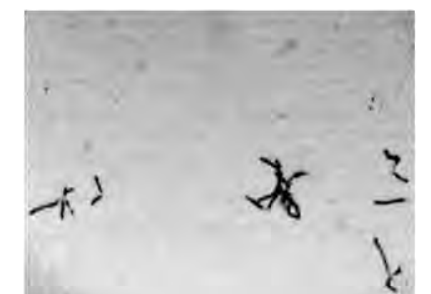

Figura VII.4 - Cinética de crecimiento de la cepa de $B$. diazoefficiens que expresa pleD* A. Media de la densidad óptica $\left(\mathrm{DO}_{500}\right)$ de la cepa que lleva el plásmido vacío (Bd-pFAJ y la cepa que lleva el gen ple $D^{*}$ de $C$. crecentus ( $B d$-pFAJ::ple $\left.D^{*}\right)$ en función del tiempo. B. Recuentos de unidades formadoras de colonias en función del tiempo en placas sin antibiótico y con antibiótico (Tc). C. Fotografías tomadas con microscopio óptico $(1000 \mathrm{X})$ en fase exponencial $\left(\mathrm{DO}_{500}=0,7\right)$ teñidas previamente con cristal violeta.

\section{VII.2.3 Efecto de la expresión de ciclasas heterólogas sobre la movilidad en B. diazoefficiens}

Para establecer si la expresión de PleD*o de TpbB poseía algún efecto sobre la síntesis de los flagelos o la capacidad de nado, realizamos extracción de flagelinas extracelulares de sobrenadantes de cultivos líquidos y ensayos de natación en agar semisólido. La cepa que expresa TpbB no mostró diferencias en la capacidad de nado o en la síntesis de flagelinas extracelulares (Figura VII.5). Para descartar que la falta de fenotipo se deba a una deficiencia en el clonado del gen, decidimos expresar el plásmido pFAJ::tpbB en una cepa de $P$. aeruginosa DGCO. El plásmido logró restituir el fenotipo de formación de biofilms en este microorganismo (Sisti, comunicación personal y resultado no mostrado), lo que nos asegura que la correcta expresión del gen desde este plásmido. En este sentido, mediante búsqueda a través del servidor Blastp no fue posible encontrar ninguna proteína similar a TpbB, ni la quinasa que la activa TpbA (Ueda y Wood, 2009), en el genoma de B. diazoefficiens. A raíz de ello, suponemos que esta DGC de $P$. aeruginosa no sería funcional y/o no se estaría activando por fosforilación en $B$. diazoefficiens. 
A

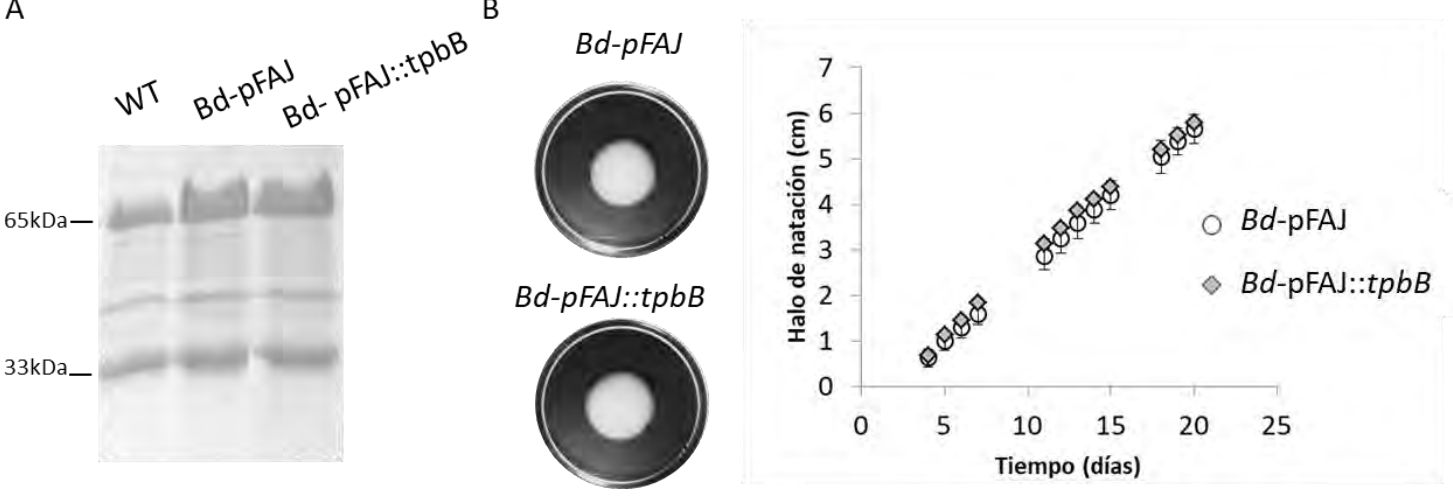

Figura VII.5 - Perfil de flagelinas (A) y ensayos de movilidad en agar semisólido (B) de la cepa de $B$. diazoefficiens que expresa $t p b B$. A. SDS-PAGE de flagelinas extracelulares de la cepa que contiene el plásmido vacío ( $B d$-pFAJ) y $B d$-pFAJ::tpbB B. Ensayo de natación en agar semisólido de la cepa que contiene el plásmido vacío y la que sobreexpresa TpbB. Se muestran fotos representativas de cada cepa en placas de Petri a los 16 días. Los halos de natación de tres réplicas técnicas fueron registrados en función de los días y graficados con el desvío estándar.

Por otro lado, la cepa que expresa PleD*presentó un efecto inusual sobre su capacidad de natación. Luego de una semana de iniciados los ensayos, observamos que la cepa que expresaba PleD* fue incapaz de nadar, comparado con la cepa que lleva el plásmido vacío (Figura VII.6). A lo largo de los días, llegando a la segunda semana, solo algunas de las placas replicas inoculadas con $B d$-pFAJ::ple ${ }^{*}$, mostraron un halo de natación incluso más grande (y más difuso) que la cepa que lleva el plásmido vacío. Además, la variabilidad de las réplicas técnicas fue muy notoria (Figura VII.6-B). A raíz de ello, tomamos una muestra de bacterias del borde del halo de natación de la cepa $B d$-pFAJ::pleD* y las repicamos en placas con medio fresco en presencia del antibiótico codificado en el plásmido. Luego de tres semanas de incubación no observamos colonias, por lo tanto, suponemos que existe una presión de selección en las placas de natación que provoca la pérdida del plásmido, a pesar de que esto no sucede en medio líquido (Figura VII.4).

Inicialmente, la extracción de flagelinas extracelulares de la cepa que expresa PleD* fue realizada mediante el protocolo estándar explicado en Materiales y Métodos. Sin embargo, siguiendo este protocolo no pudimos observar la presencia de flagelinas subpolares ni laterales en dicha cepa. A raíz de ello, decidimos cambiar las condiciones de extracción utilizando un mayor volumen de cultivo $(50 \mathrm{ml})$. Las muestras fueron resuspendidas en el menor volumen posible y todo el extracto obtenido fue sembrado en un gel SDS-PAGE. De esta forma, observamos que la cepa que expresa PleD* fue capaz de sintetizar flagelinas subpolares, aunque en muy poca cantidad (Figura VII.6-A). 
A

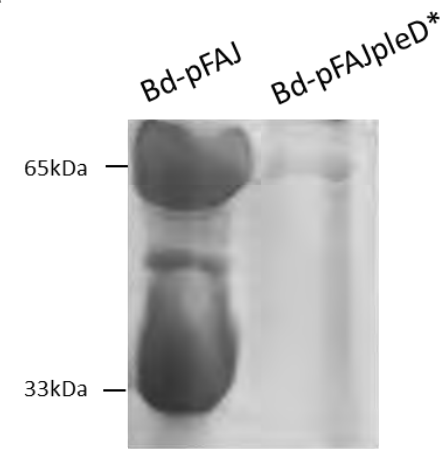

B

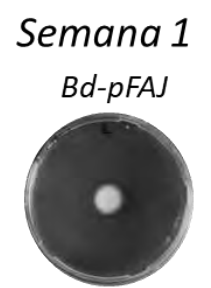

Bd-pFAJ:pleD*

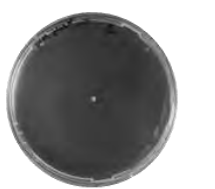

\section{Semana 2}
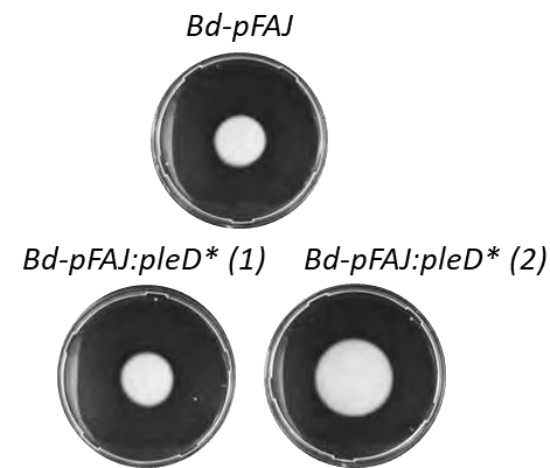

Figura VII.6 - Perfil de flagelinas (A) y ensayos de movilidad en agar semisólido (B) de la cepa de $B$. diazoefficiens que expresa $p / e D^{*}$. A. SDS-PAGE de flagelinas extracelulares de la cepa que contiene el plásmido vacío $(B d$-pFAJ) y $B d$-pFAJ::pleD* B. Ensayo de natación en agar semisólido de la cepa que contiene el plásmido vacío y la que sobreexpresa PleD*. Se muestran fotos representativas de cada cepa en placas de Petri a los 7 y 12 días. (1) y (2) representan réplicas técnicas de un mismo ensayo de natación.

\section{VII.2.4 Efecto de la expresión de ciclasas heterólogas sobre la producción de EPS y la formación de biofilms en $B$. diazoefficiens}

Es conocido que, además de afectar la movilidad, la expresión de PleD* en otros rizobios provoca un aumento en la producción de EPS y la capacidad de formar biofilms (Pérez-Mendoza et al., 2014). Para analizar si este efecto también se observaba en $B$. diazoefficiens, realizamos un ensayo preliminar de unión a Rojo Congo de las cepas obtenidas. La Figura VII.7-A muestra fotos de los pellets luego del ensayo, donde la cepa $B d$-pFAJ::ple $D^{*}$ fue capaz de unir 1,5 veces más este colorante que la cepa que posee el plásmido vacío. Esto podría indicar una diferencia en la síntesis de EPS por lo cual, realizamos un ensayo cuantitativo. Efectivamente, encontramos que la capacidad de producción de EPS de la cepa que expresa PleD* fue varias veces mayor (7,5 veces) que la cepa que contiene el plásmido vacío como se muestra en la Figura VII.7-B.

Dada la gran capacidad de producción de EPS de $B d$-pFAJ::ple $D^{*}$, nos preguntamos si la misma podría verse traducida en un aumento en la capacidad de formar biofilm en tubos de vidrio. Así, pudimos detectar que, tanto en tiempos tempranos como en tiempos largos, la cepa que expresa PleD* fue capaz de adherirse al vidrio formando biofilm en mayor medida que la cepa que contiene el plásmido vacío (Figura VII.8). 
A

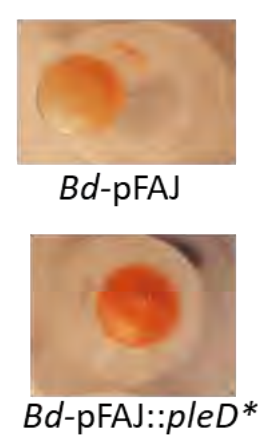

B

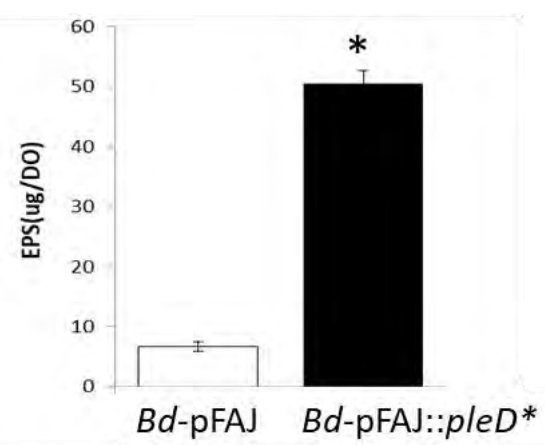

Figura VII.7 - Producción de EPS de la cepa de B. diazoefficiens que expresa pleD*. A. Foto de los pellets luego del ensayo de unión a Rojo Congo de la cepa $B d$-pFAJ y $B d$-pFAJ::ple $D^{*}$. B. Ensayo de cuantificación de EPS mediante el método de antrona en fase exponencial de crecimiento. EI asterisco representa diferencias significativas utilizando ANOVA con $p=0.05$.
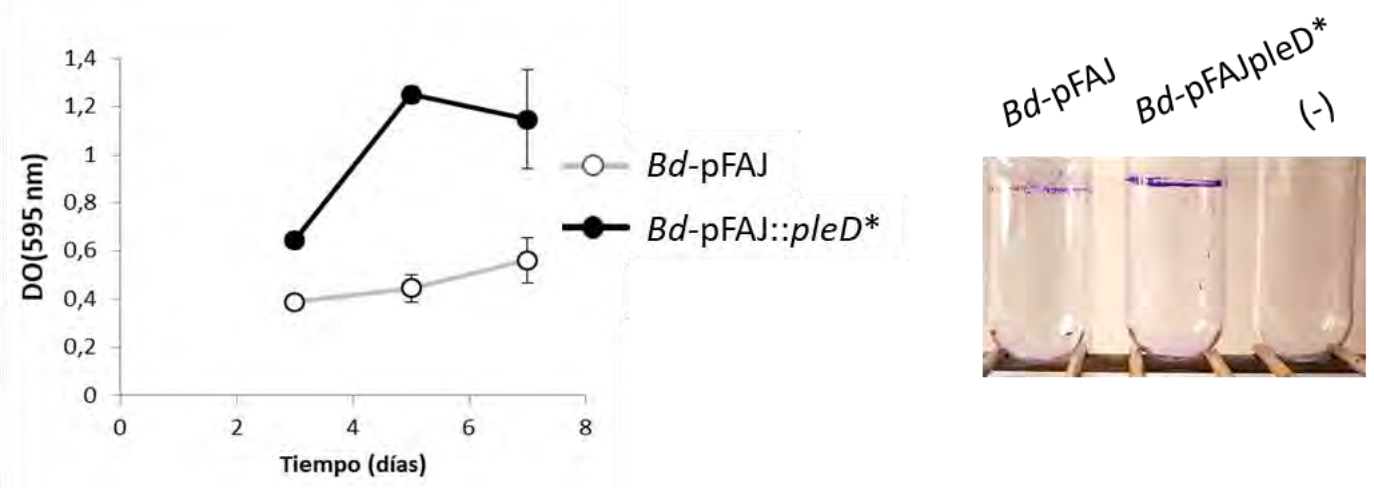

Figura VII.8 - Adhesión a tubos de vidrio de la cepa $B$. diazoefficiens que expresa pleD*. Ensayo de adhesión a vidrio de $B d$-pFAJ y $B d$-pFAJ::ple $D^{*}$. La medida de $\mathrm{DO}_{595}$ muestra la cantidad de cristal violeta adherido a los 3,5 y 7 días de comenzado el ensayo. A la derecha se muestra una foto representativa de los tubos de vidrio a los 7 días.

\section{VII.2.5 Efecto del c-di-GMP sobre los reguladores del sistema flagelar subpolar}

Como mencionamos en la Introducción (Capítulo I.5), el c-di-GMP, es capaz de unirse a dominios del tipo AAA+ presente en algunas proteínas con actividad ATPasa (Jenal et al., 2017). Esto convierte a estas proteínas en posibles efectoras que responden a c-di-GMP o susceptibles de una posible regulación alostérica.

FleQ, el regulador maestro de la síntesis flagelar en $P$. aeruginosa, responde a c-diGMP a través de su dominio AAAt, modificando la síntesis del flagelo y al mismo tiempo regulando la producción de uno de sus EPS (Baraquet et al., 2012; Su et al., 2015; Ha y O’Toole, 2015). Por otro lado, en el Capítulo V, demostramos que FlbD, una EBP dependiente de $\sigma^{54}$ que posee un dominio AAAt, regula un paso de la síntesis del flagelo subpolar. En el mutante $\triangle f l b D$ también se observó una correlación entre la síntesis flagelar y la producción de EPS (Capítulo V.4.5), de manera similar a lo que se observa en $P$. aeruginosa. Por esta razón, y sumado a que la cepa que expresa PleD* 
mostró afectada la síntesis flagelar, nos preguntamos si el segundo mensajero c-diGMP podría tener algún efecto sobre la regulación que ejerce FlbD.

Para ello, decidimos cuantificar los niveles de ARNm, de distintos genes reguladores y algunos de los genes estructurales que están bajo el control de FlbD, en la cepa que expresa PleD*. Si los niveles de c-di-GMP ejercen algún efecto sobre FlbD modificando su actividad, esperaríamos observar cambios en los niveles de ARNm en los genes estructurales de clase III que están bajo su regulación, pero no, en los reguladores que están arriba en la jerarquía transcripcional. El resultado encontrado se muestra en la Tabla VII.2. Como se puede ver, encontramos que los niveles de ARNm de todos los genes medidos aumentaron en la cepa que expresa PleD* (Tabla VII.2). Este resultado fue muy llamativo, dada la poca cantidad de flagelinas subpolares y la menor capacidad de natación que presentó la cepa $B d$-pFAJ::ple ${ }^{*}$. Se puede apreciar que todos los genes medidos mostraron niveles mayores que la cepa parental, incluso el probable regulador maestro CtrA, y el regulador de clase II FlbD. Esto no condice con el fenotipo que muestra la cepa y por lo tanto no nos permitió establecer una relación directa entre los niveles de c-di-GMP y la función de FlbD.

En general, está demostrado que la señal de c-di-GMP regula de manera negativa la movilidad de la bacteria, sin embargo, en $B$ diazoefficiens todavía no pudimos determinar el mecanismo mediante el cual ejerce su acción este segundo mensajero. Como mencionamos en la introducción (Capítulo I.5.2), existen otras proteínas además de las EBP con dominios AAAt, que podrían responder al c-di-GMP y actuar sobre los sistemas flagelares, como por ejemplo la quinasa CckA, la ATPasa Flil, o proteínas que interactúan con el motor como por ejemplo YcgR o DgrA.

TablaVII.2 - Niveles de ARN mensajeros de genes del flagelo subpolar en la cepa $B$. diazoefficiens pFAJ::ple $D^{\star}$.

\begin{tabular}{c|c|c}
\hline Gen & Fold change & Función \\
\hline ctrA & 3 & Regulador maestro \\
flbD & 3 & Regulador de clase II \\
flgF & 3,5 & Proteínas estructurales \\
$f l g E_{5}$ & 2 & de clase III \\
flik & 3,3 &
\end{tabular}

Los resultados se expresaron como foldchange de la cepa que expresa PleD* $(B d$-pFAJ::pleD*) sobre la cepa que contiene el plásmido vacío (Bd-pFAJ ). 


\section{VII.3 Caracterización de una DGC y PDE de $B$. diazoefficiens}

Como mencionamos al principio de este Capítulo, Bll1502 es una de las pocas proteínas que se encuentra conservada en los rizobios analizados por Gao y colaboradores. En B. melitensis se ha estudiado un homólogo a Bll1502 (BME_RS07270) y que denominaron BpdA (Petersen et al., 2011). El alineamiento de secuencias entre ambas proteínas se encuentra en el Anexo Figura AVII.1. Esta proteína posee dominios de síntesis y degradación (GGDEF y EAL) y se encuentra involucrada en el control de la expresión de genes flagelares ( $f l i F, f l g E, f l g B$ ) en dicha bacteria (Petersen et al., 2011). Recientemente se ha caracterizado el rol de una proteína homóloga a BpdA en E. meliloti (llamada RgsP) aunque en este rizobio la proteína parece ser esencial y se encuentra involucrada en la síntesis del peptidoglicano (Cowie et al., 2006; Schäper et al., 2018).

Los clonados para la construcción de un mutante en bll1502 fueron realizados durante el trabajo final del Lic. Julián Ballare. A pesar de que realizó varios intentos, la mutación de este gen no resultó exitosa. Luego de varias repeticiones más hemos logrado obtener un posible mutante mediante inserción de un cassette de resistencia a gentamicina $(\mathrm{Gm})$, al que llamamos 1502::Gm. Este mutante ha podido ser corroborado con primers externos de una sola de las regiones flanqueantes a la zona de recombinación. Esta PCR fue enviada a secuenciar y así fue comprobada la inserción correcta del cassette de resistencia a gentamicina en bll1502. El mutante obtenido mostró un fenotipo $\mathrm{Gm}^{\mathrm{R}}, \mathrm{Km}^{\mathrm{S}}$, por lo que no creemos que la dificultad en chequear la otra región flanqueante se deba a la selección de un recombinante simple.

Dado que las DGC y PDE actuarían como un complejo en una región determinada de la célula (Dahlstrom et al., 2015), decidimos estudiar la probable DGC adyacente codificada en bll1500. Para ello, obtuvimos una cepa de $B$. diazoefficiens mutante en ese gen, al cual denominamos $\Delta 1500$ (Dardis, Trabajo final de licenciatura 2013). Este gen codifica una proteína que posee un único dominio GGDEF, y dada la cercanía genómica creemos que podría encontrarse actuando de manera conjunta con el homólogo a BpdA.

Para comenzar la caracterización de los mutantes, realizamos pruebas de movilidad y síntesis flagelar (Figura VII.9). El mutante 1502::Gm mostró afectada su capacidad de natación, mientras que $\Delta 1500$ no mostró diferencias en su capacidad de nado respecto de la cepa WT. 
A

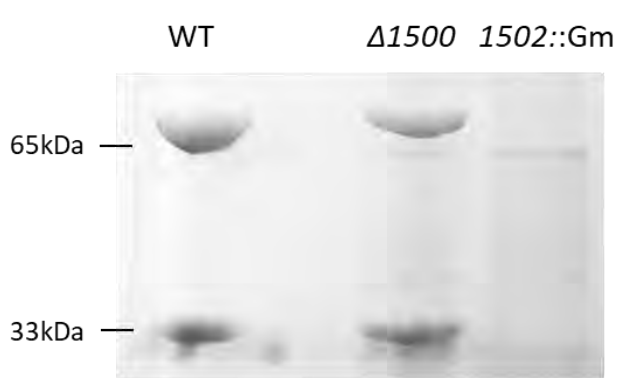

B
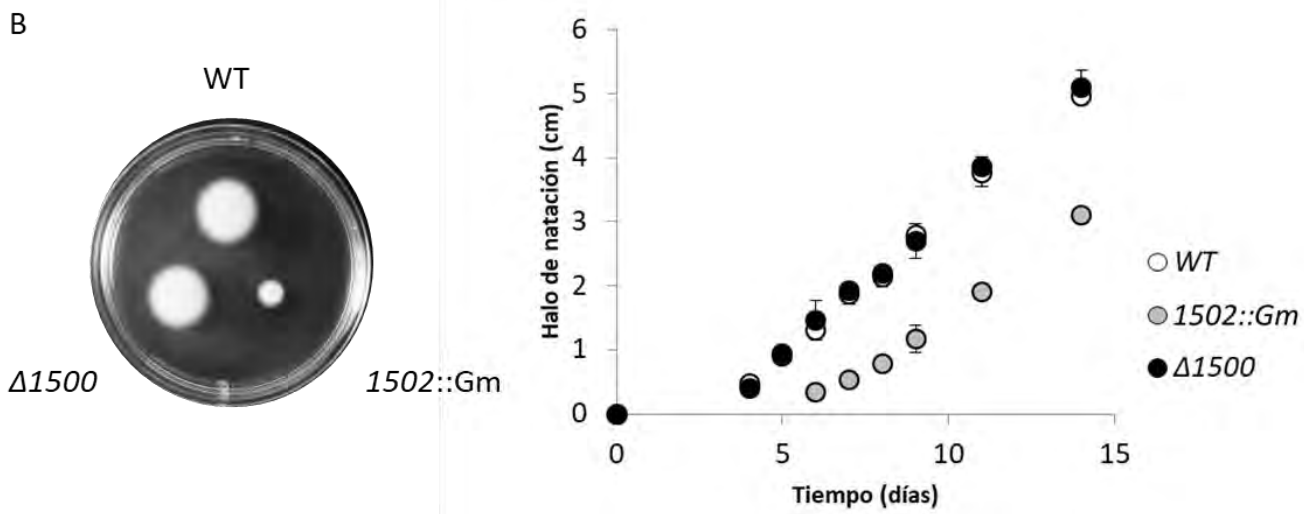

Figura VII.9 - Perfil de flagelinas (A) y ensayos de movilidad en agar semisólido (B) de las cepas de $B$. diazoefficiens mutantes en los genes bll1502 y bll1500. A. SDS-PAGE de flagelinas extracelulares de las cepas WT, 1502::Gm y $\Delta 1500$. B. Ensayo de natación en agar semisólido de la cepa WT, 1502::Gm y $\Delta 1500$. Se muestra una foto representativa de las tres cepas inoculadas en placa de Petri a los 8 días. Los halos de natación de tres réplicas técnicas fueron registrados en función de los días y graficados con el desvío estándar.

Adicionalmente, realizamos estudios de adhesión al vidrio para analizar el rol de cada uno de estos genes (bll1502 y bll1500) en el proceso de formación de biofilms (Figura VII.9). La cepa 1502::Gm mostró mayor capacidad de adherirse al vidrio comparado con la cepa WT, en cambio la cepa $\Delta 1500$ mostró menor capacidad de adherirse al vidrio a los 3 y 5 días (a juzgar por las fotos) y luego igualó a la cepa WT (Figura VII.10). 


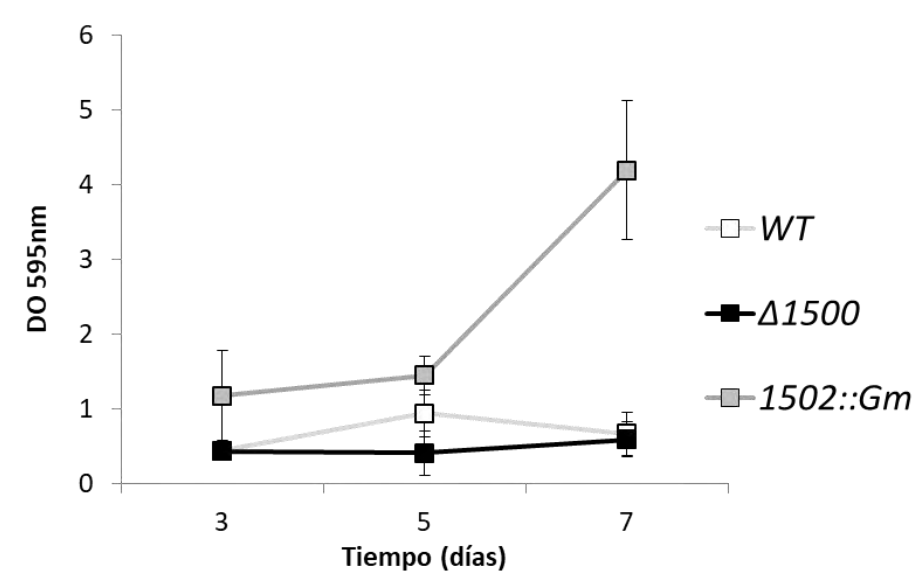

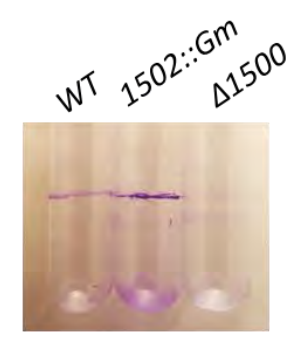

Día 3

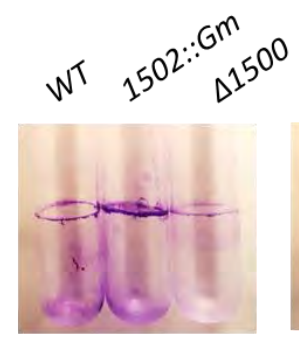

Día 5

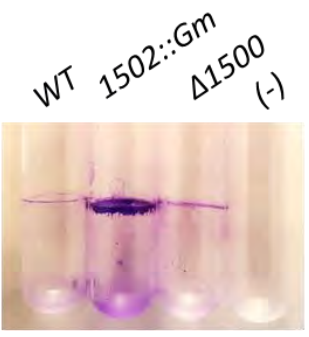

Día 7

Figura VII.10 -Ensayo de adhesión a tubos de vidrio de las cepas de $B$. diazoefficiens mutantes en bll1502 y bll1500. Ensayo de adhesión a tubos de vidrio. Arriba se muestra el resultado de una réplica biológica representativa en la que se graficó el promedio de absorbancia del cristal violeta adherido el cual fue realizado por triplicado para la cepa WT y los mutantes en bll1502 y bll1500. Abajo se muestran fotos del halo de adhesión a los 3,5 y 7 días.

Bll1502 posee un dominio de síntesis y de degradación de c-di-GMP, por lo tanto, podría actuar tanto como DGC como PDE. Dado que mayores concentraciones de c-diGMP favorecen el estado de vida sésil, la baja performance de natación de 1502::Gm y la mayor capacidad de adherirse al vidrio, nos induce a pensar que Bll1502 estaría actuando como PDE. EL rol de Bll1500 no pudo ser determinado a través de la estrategia de mutagénesis planteada, aunque parecería estar involucrada en parte en el proceso de formación de biofilms en etapas tempranas.

\section{VII.4 Conclusión y perspectivas}

Para comenzar a indagar el efecto del c-di-GMP sobre $B$. diazoefficiens hemos realizado estudios mediante expresión heteróloga de diguanilato ciclasas descriptas en otras bacterias. Así, se obtuvieron cepas que expresan la ciclasa TpbB de $P$. aeruginosa y la ciclasa PleD* de $C$. crescentus en $B$. diazoefficiens. La expresión de TpbB no produjo un fenotipo apreciable, probablemente pueda deberse a la necesidad de fosforilación para activar la proteína. Este inconveniente no ocurrió con la cepa que expresa PleD* ya que la misma no requiere fosforilación ya que presenta una mutación 
que la hace constitutivamente activa. PleD es importante para el desarrollo y morfogénesis polar durante el ciclo celular en C. crescentus (Jenal et al., 2017). El hecho de que la transcripción de pleD* esté sujeta al control del promotor del plásmido utilizado (pneo) y que la proteína se encuentre constitutivamente activa en $B$. diazoefficiens, puede explicar los defectos observados en la citoquinesis.

La cepa que expresa PleD* también mostró defectos en su capacidad de natación, ya que se observó una deficiencia en la síntesis de sus dos sistemas flagelares. Sin embargo, cuando escalamos los niveles de cultivo y extrajimos flagelinas observamos baja cantidad de flagelinas subpolares en esta cepa, a pesar de que presentó altos niveles de transcripto de los genes flagelares subpolares, respecto de la cepa WT.

El aumento de c-di-GMP producto de la expresión de PleD* podría estar actuando sobre otro nivel en la síntesis flagelar. En C. crescentus esta proteína participa de la eyección del flagelo (Aldridge y Jenal, 1999). Esto podría estar sucediendo con el flagelo subpolar de $B$. diazoefficiens. El filamento del flagelo subpolar podría estar sintetizándose parcialmente y eyectándose. Esto explicaría la presencia de bajas cantidades de flagelinas subpolares observadas en la cepa que expresa PleD*. Así el aumento en los niveles de transcripto de los reguladores del flagelo subpolar quizá se deba a una necesidad de formar esta estructura. Esta hipótesis podría evaluarse mediante microscopía electrónica de transmisión que nos permitiría observar la ultraestructura del filamento y su localización en la membrana.

También observamos que la cepa que expresa PleD* fue capaz de sintetizar gran cantidad de exopolisacáridos. Esto, y el alargamiento de las células podría explicar el aumento de la densidad óptica cuando la cepa que expresa PleD* deja de crecer. Además, esta cepa mostró mayor capacidad de adherirse al vidrio, lo que coincide con un posible aumento del c-di-GMP intracelular y la inducción al estado de vida sésil.

Por otro lado, detectamos una proteína similar a BpdA descripta en B. melitensis (que posee dominios PDE y DGC), la cual se encuentra muy conservada en especies cercanas a $B$. diazoefficiens e incluso en otros rizobios analizados (Petersen et al., 2011; Gao et al., 2015). Mediante mutagénesis dirigida detectamos que 1502::Gm presentó dificultades para la síntesis de sus dos sistemas flagelares y una mayor capacidad de adhesión al vidrio. Dado los fenotipos observados esta proteína estaría actuando como PDE, ya que al no estar aumentarían los noveles de c-di-GMP y favorecerían el paso al estado de vida sésil. Además en $B$. melitensis la mutación de bpdA provocó una disminucíón en los niveles de transcripto de los genes flif (que codifica una proteína del cuerpo basal), flgE (que codifica una proteína del gancho) y $f l g B$ (que codifica una proteína del bastón). De manera similar a la realizada con la cepa que expresa PleD, sería interesante medir los niveles de ARNm de ciertos genes flagelares sobre el mutante 1502::Gm para determinar si los mismos se encuentran afectados en alguna etapa determinada de la cascada de síntesis de ambos sistemas flagelares. 


\section{VII.5 Anexo}

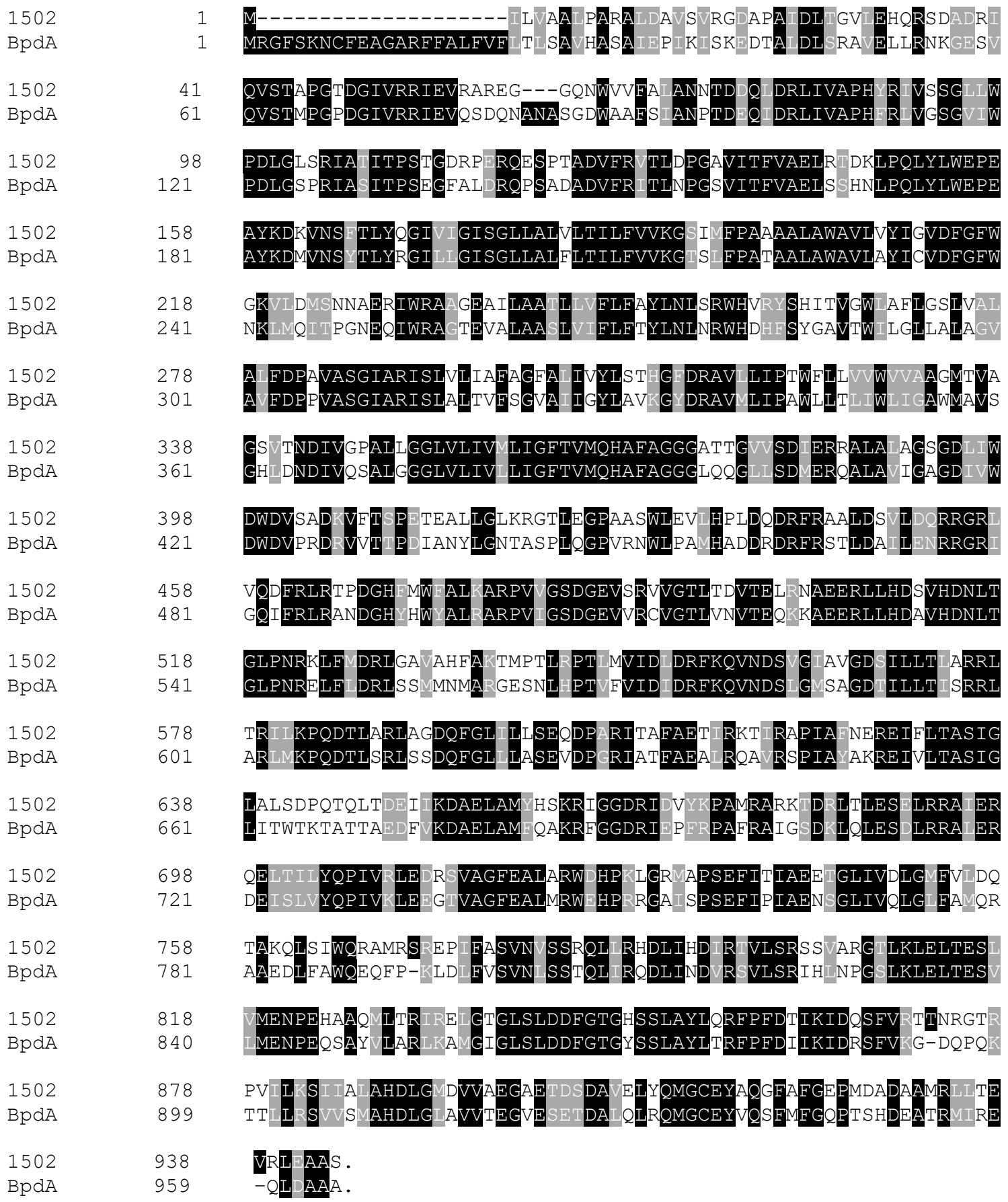

Figura AVII.1 - Alineamiento de Bll1502 de B. diazoefficiens y BpdA de B. melitensis. 
Capítulo VIII: Discusión 

B. diazoefficiens constituye una de las pocas bacterias del suelo que posee dos sistemas de flagelos, uno subpolar y otro lateral, cada uno de ellos con diferentes características. Generalmente, en las bacterias que presentan sistemas flagelares duales, el sistema (sub)polar se expresa en medios líquidos y propulsa el movimiento de natación, mientras que el sistema lateral (de carácter inducible) es requerido habitualmente para el movimiento tipo swarming, y se expresa ante una señal que dificulta la rotación del flagelo (sub)polar, como por ejemplo aumentos de la viscosidad del medio o contacto con una superficie (McCarter, 2004; Merino et al., 2006). Este no es el caso de $B$. diazoefficiens, ya que ambos sistemas flagelares son utilizados para natación en medios líquidos. Además, el patrón de nado de esta bacteria es una propiedad emergente de la interacción entre ambos flagelos (Quelas et al., 2016a), lo que contribuye a que su estudio sea aún más atractivo.

La síntesis y rotación de estas estructuras requiere de un gran gasto energético por parte de la célula. En este sentido, los flagelos laterales de $B$. diazoefficiens consumen mucha energía, sin aportar en la misma medida a la natación comparado con el flagelo subpolar (Cogo et al., 2018) y la mitad de las especies de Bradyrhizobium no lo tienen, incluyendo especies que nodulan soja. A su vez, dentro del filogrupo que sí lo tienen, existen varias cepas que lo perdieron (Garrido-Sanz et al., 2019). Resulta paradójico el hecho que se hayan mantenido ambos flagelos a lo largo de la evolución en algunos linajes.

El flagelo subpolar de $B$. diazoefficiens es un flagelo monótrico, que contribuye al movimiento de natación fundamentalmente en trayectorias rectilíneas, participa en el proceso de adhesión a superficies hidrofílicas y en la quimiotaxis hacia succinato y glutamato (Quelas et al., 2016).

Al iniciar este trabajo de Tesis, mostramos seis posibles clusters de genes presentes en el genoma de $B$. diazoefficiens que codificarían proteínas estructurales y regulatorias de la cascada de síntesis de su flagelo subpolar. Determinamos, mediante estrategias de mutagénesis sitio-dirigida, que los genes del motor ubicados en el cluster 1 ( $\left.\operatorname{mot} A B_{1}\right)$ no serían necesarios para la rotación del flagelo subpolar en las condiciones ensayadas. Los genes del motor ubicados en el cluster 4 (pomAB), en cambio, serían imprescindibles para el correcto funcionamiento del flagelo subpolar, aunque se ha reportado que el mismo no utilizaría $\mathrm{H}^{+}$, a diferencia de otros flagelos cuyos estatores están formados por proteínas PomAB (Kawagishi et al., 1996; Kanbe et al., 2007; Wilhelms et al., 2009).

Por otro lado, determinamos que los genes que codifican proteínas del gancho, presentes en el cluster $3\left(f l g D E K L_{3}\right)$, no serían necesarios para formar la estructura del flagelo subpolar de $B$. diazoefficiens. En este mismo cluster además, se encuentran otros genes que codifican proteínas del filamento que no poseen genes parálogos dentro de los otros seis clusters, como son fliD, flis y flaA. Este último gen codifica una probable flagelina, pero dado su bajo peso molecular, parecería no formar parte del filamento del flagelo subpolar. Además, encontramos que ambos operones flgDEKL $L_{3}$ y fliDS no 
responden a la regulación en cascada a través de FlbD como sí lo hacen los genes del gancho ubicados en los clusters 5 y 6.

A su vez, hemos logrado caracterizar parcialmente los reguladores que controlan su cascada regulatoria. A partir de los datos que hemos generado, presentamos a continuación un modelo regulatorio de la síntesis del flagelo subpolar para $B$. diazoefficiens USDA 110.

\section{Cascada regulatoria del sistema flagelar subpolar de B. diazoefficiens USDA 110}

CtrA es un regulador de respuesta cuya fosforilación depende de un sistema de transferencia de fosfatos (Laub et al., 2007; Francez-Charlot et al., 2015). Esta proteína se encuentra conservada en la gran mayoría de las $\alpha$-proteobacterias, y cumple diversos roles, siendo fundamental para la viabilidad de algunas especies de esta clase por su participación en el proceso de división celular (Quon et al., 1997; Barnett et al., 2001; Brilli et al., 2010). Por el contrario, en otras $\alpha$-proteobacterias CtrA se ha especializado y sólo participa de la regulación de la síntesis flagelar o de algún proceso específico (Mercer et al., 2010; Francez-Charlot et al., 2015). En B. diazoefficiens la proteína Bll2200 es homóloga a CtrA, y suponemos que es esencial en esta especie, ya que no hemos podido inactivar al gen que la codifica por mutación. Dado que este hecho no constituye una prueba fehaciente, esta afirmación debería probarse mediante otra estrategia experimental. Sin embargo, otra evidencia que sustenta esta hipótesis, aunque también indirecta, es la imposibilidad de generar mutantes donde se inactive el gen cckA (bll5808), que codifica la quinasa del sistema de transferencia de fosfato que activa CtrA.

El impedimento en la generación del mutante en $\operatorname{ctr} A$, no nos permitió corroborar su rol como regulador maestro del flagelo subpolar. A pesar de ello, hemos detectado la presencia de cajas promotoras características, basadas en las cajas reconocidas por CtrA en $C$. crescentus, en genes del cuerpo basal ( $f l i F, f l i L, f l g B, f l i l)$, en reguladores que actúan posteriormente en la cascada regulatoria de $C \operatorname{trA}\left(f l i X, f l a F_{S}, f l b T_{S}\right.$ y flbD -último gen del operón de fliF) y en las cuatro flagelinas subpolares de $B$. diazoefficiens (aunque para flic4 se encontraría luego del inicio de la transcripción). Todo ello da indicios de su posible función como regulador maestro de la síntesis del flagelo subpolar en $B$. diazoefficiens USDA 110.

Por otro lado, identificamos las proteínas FlbD (Blr7003) y FliX (Bll5837) como reguladores involucrados por debajo del regulador maestro en la jerarquía regulatoria de la síntesis del flagelo subpolar en $B$. diazoefficiens. Cuando analizamos el rol de estas proteínas dentro de la cascada regulatoria, encontramos que ambas controlan la transcripción de genes que codifican el bastón distal ( $f(g F)$ y el gancho del flagelo $\left(f l g E_{5}\right.$ y flik), que se encuentran en los clusters 5 y 6 . Sin embargo, también encontramos genes flagelares (fliF y flil) que se encuentran regulados por FlbD, pero no por FliX. Los cambios en los niveles de transcripto de estos genes fueron un orden de magnitud menor que los 
de genes que codifican proteínas del gancho y el bastón distal. Esto podría constituir una regulación fina por parte de FlbD sobre estos genes que codifican el cuerpo basal, sobre todo flil, que codifica la ATPasa del SSTIII y cuya transcripción estaría sujeta a una regulación negativa por parte de FlbD. Este punto será explorado con mayor detalle utilizando otras aproximaciones.

Además, FlbD regula la transcripción de tres de las cuatro flagelinas subpolares: FliC2, FliC3 y FliC4 (las tres con mayor porcentaje de identidad de las cuatro flagelinas entre sí). En el modelo descripto en $C$. crescentus también se ha encontrado una regulación diferencial de sus seis flagelinas, lo que derivó en su clasificación en dos grupos: $\alpha$ para las reguladas por CtrA y $\beta$ para las reguladas por FlbD (Ardissone $y$ Viollier, 2015). Si bien podría estar sucediendo algo similar en B. diazoefficiens, la disminución relativa en la cantidad de transcripto en los niveles de ARNm de las flagelinas con respecto a la cepa WT es pequeña comparada con la observada para los genes del bastón y gancho. Por ello, proponemos que FlbD no sería el único regulador de estos genes, sino que podría influir en su transcripción en momentos de alto requerimiento de los mismos.

Como mencionamos anteriormente, el otro protagonista en esta etapa de regulación es FliX, una pequeña proteína citosólica que actúa como regulador de FlbD en trans. FliX no solo es capaz de unirse a FlbD y modular su función, sino que también podría encontrarse asociada a la membrana bacteriana y de esta manera participaría en el mecanismo de percepción del estado de formación del flagelo (Muir y Gober, 2002). Así, FliX actuaría como un punto de control, es decir, promovería la transcripción de genes de la tercera etapa de la síntesis del flagelo solo si la estructura previa se encuentra correctamente ensamblada.

En este trabajo demostramos que FliX también es requerido para la formación del gancho y el bastón distal del flagelo subpolar en $B$. diazoefficiens. No hemos determinado su posible rol como punto de control entre el ensamblado del cuerpo basal y la transcripción de genes de clase III, lo que continúa siendo una incógnita y requerirá de mayor investigación.

La actividad de FlbD no solo depende de su trans-regulador, FliX, sino también del factor $\sigma^{54}$ (Wu et al., 1995). B. diazoefficiens posee dos genes que codifican factores $\sigma^{54}$ : blr1883 (rpoN1) y blr0732 (rpoN2), los cuales en determinadas condiciones pueden complementar su función mutuamente (Kullik et al., 1991). Estudios previos en mutantes dobles de estos factores $\sigma^{54}$ mostraron que los niveles de ARNm de ciertos genes que codifican estructuras del flagelo subpolar se encontraron disminuidos comparados con los de la cepa WT (Hauser et al., 2007). Entre ellos se identificaron genes del operón que contiene a flgF (blr5827-blr5830), flg $E_{5}$ (bll5852-bll5854), flgl (blr5838-blr5840), flik (bll6996-bll6997) y flic2 (bll5844). Estos datos coinciden con los nuestros, con excepción de los genes ubicados en el operón de $\mathrm{flgl}$. El hecho de que en el ensayo de microarray sólo encuentren afectados los niveles de ARNm de flic2, podría deberse al grado de similitud de secuencia de las flagelinas. En este trabajo logramos 
determinar que FlbD actúa únicamente a través del parálogo RpoN2, y no es capaz de hacerlo a través de RpoN1.

Desde el punto de vista funcional, FlbD no solo depende del factor $\sigma^{54}$, sino que también podría ser sensible a una modificación post-traduccional. Esta modificación en las proteínas EBP clásicas (pertenecientes a la familia $\mathrm{NtrC}$ ) induce la oligomerización de la proteína y con ella, su activación. En C. crescentus, se propone que esta regulación se encontraría relacionada con la progresión del ciclo celular (Ramakrishnan y Newton, 1990) y el momento en que esta proteína debe activar la síntesis de su flagelo. En $B$. diazoefficiens no observamos este fenotipo, y la actividad de FlbD pareciera ser independiente de fosforilación. Incluso los reguladores de clase II, FlbD y FliX, parecen haberse especializado en la regulación del flagelo subpolar y no estarían relacionados con la regulación y la progresión del ciclo celular. Esto muestra cierta especialización de parte de la vía en el control de la síntesis del flagelo respecto de la división celular.

Otro mecanismo post-traduccional involucrado en la actividad de reguladores dependientes de $\sigma^{54}$, como FleQ y FlrA, consiste en una modificación alostérica por medio de c-di-GMP. Estos reguladores poseen un dominio $A A A+$, el cual es capaz de unir c-di-GMP y modificar la función de estas proteínas (Baraquet et al., 2012; Srivastava et al., 2013; Su et al., 2015). En P. aerugionosa FleQ es activador de la transcripción de genes flagelares y a la vez represor de los genes pel (necesarios para la síntesis de un tipo de exopolisacárido rico en glucosa). En presencia de c-di-GMP, la transcripción flagelar se frena y la síntesis de Pel se activa (Hickman y Harwood, 2008; Baraquet et al., 2012).

En $B$ diazoefficiens, FlbD también presentó una regulación positiva de los genes flagelares y negativa en la síntesis de exopolisacáridos. Para poner de manifiesto si este regulador era capaz de responder a las concentraciones de c-di-GMP al igual que lo hacen FleQ o FlrA, realizamos medidas de los niveles de transcripto de genes flagelares regulados por FlbD en una cepa que expresa constitutivamente una DGC y por lo tanto podría tener mayores niveles de c-di-GMP. Sin embargo, la aproximación utilizada no nos permitió identificar si el segundo mensajero c-di-GMP es capaz de modificar la función de FlbD manera alostérica. Si bien determinamos que la expresión de una DGC constitutivamente activa (PleD*) modifica la expresión del flagelo subpolar, no pudimos identificar el punto donde se ejerce esta regulación. Sería interesante en el futuro continuar trabajando con esta hipótesis e identificar si FlbD es capaz de unir c-di-GMP en su dominio AAA+ conservado y de esta manera regular la síntesis de exopolisacáridos en esta bacteria.

Para completar la caracterización de la regulación de la síntesis del flagelo subpolar estudiamos los posibles reguladores de clase III, FlaF (Bll5842) y FlbT (Blr5847). En el modelo de $C$. crescentus, FlbT y FlaF regulan la síntesis de las flagelinas a nivel posttranscripcional e intervienen en el punto de control de la finalización de la construcción del gancho. En B. diazoefficiens observamos que FlaFs (Bll5842) y $\mathrm{FlbT}_{\mathrm{S}}$ (Blr5847) efectivamente modifican los niveles de ARNm de las flagelinas de manera similar al 
modelo descripto previamente. $\mathrm{FlaF}_{\mathrm{S}}$ tiene un efecto positivo sobre los mensajeros de las flagelinas fliC234 mientras que $\mathrm{FlbT}_{\mathrm{S}}$ cumple el rol opuesto. Por otra parte, los niveles de ARNm de la flagelina flic1 escapan a esta regulación, al igual que sucede con la regulación a través de FlbD-FliX. Además, $\mathrm{FlaF}_{\mathrm{S}}$ estaría actuando a nivel de la traducción de las flagelinas, lo que podría constituir el punto de control de la construcción del filamento. Esta hipótesis será evaluada en un futuro en el laboratorio.

En varios microorganismos se ha determinado que algunas copias de flagelinas son más importantes que otras en la construcción y funcionalidad del flagelo (Tambalo et al., 2010; Faulds-Pain et al., 2011; Mohari et al., 2018). Lambert y colaboradores (2006) han determinado que las flagelinas que conforman el filamento de Bdellovibrio bacteriovorus poseen un orden estructural determinado dentro del mismo y algunas de sus flagelinas resultan necesarias para mantener el largo de la estructura. Además, la ausencia de una de sus flagelinas (la primera en ser ensamblada) no impide la síntesis del filamento, aunque el mismo posee desordenadas las demás flagelinas y no es funcionalmente activo. En Shewanella putrefaciens también se observa un orden determinado en la estructura de las dos flagelinas que lo conforman. En este caso, la flagelina que escapa a la regulación vía FliA es la primera en ser ensamblada y representa el $20 \%$ del filamento (similar a lo que observamos con FliC1). Esta regulación secuencial permite que se forme el filamento con un orden determinado de sus dos flagelinas dentro del eje flagelar. Si bien el filamento puede ser sintetizado con cualquiera de las dos flagelinas y en distinto orden, su morfología helicoidal varía como también lo hace su performance de natación en medios líquidos o viscosos (Kühn et al., 2018). La regulación transcripcional diferencial encontrada entre las cuatro copias de las flagelinas en $B$. diazoefficiens nos permite plantear la siguiente hipótesis: La flagelina FliC1, que no está regulada por FlbD, y cuyo mensajero estaría presente desde el inicio de la síntesis controlado por CtrA, constituye la primera flagelina en ensamblarse y actúa como punto de control para que $\mathrm{FlaF}_{\mathrm{S}}-\mathrm{FlbT}_{\mathrm{S}}$ permitan la síntesis de las flagelinas restantes (FliC234).

\section{Relación entre la regulación de la síntesis de ambos sistemas flagelares}

En B. diazoefficiens, el flagelo subpolar parece expresarse de manera constitutiva, dado que en todas las condiciones ensayadas siempre hemos podido detectarlo (no solo en este trabajo de Tesis, sino también por trabajos de otros integrantes de nuestro grupo de investigación). Esto se explicaría en parte a que CtrA podría estar involucrado de manera simultánea en la regulación de la síntesis flagelar y la división celular, similar a los que sucede en $C$. crescentus. Por otro lado, el sistema del flagelo lateral presenta un comportamiento inducible y es capaz de responder frente a diversas señales. Entre estas, podemos encontrar la fuente de carbono y la viscosidad del medio (Althabegoiti et al., 2008; Quelas et al, 2016a). En diferentes bacterias con dos sistemas flagelares también se observa que los sistemas polares/subpolares son de carácter constitutivo mientras que en estos casos el sistema lateral sólo se induce en determinados medios (McCarter, 2004). En estos microorganismos con sistemas flagelares duales se ha 
hipotetizado que la inducción del sistema lateral en ambientes viscosos se debe a que el sistema polar/subpolar detecta un impedimento en su capacidad de rotación normal y en consecuencia induce el otro sistema flagelar (Moens et al., 1996).

En B. diazoefficiens, los mutantes en los reguladores de clase II, $\Delta f l b D$ y flix::Km, presentaron un aumento de los niveles de transcripto del regulador maestro del sistema lateral (lafR) y mayor cantidad de flagelinas laterales extracelulares. Esto significa que, a pesar que la síntesis de ambos sistemas ocurre a través de cascadas regulatorias diferentes e independientes, existe una conexión entre ambos. Así, la inactivación de los reguladores FlbD y FliX deja en evidencia la posibilidad de que exista una conexión entre los sistemas regulatorios flagelares y la señal de inducción podría estar antes de la finalización del ensamblado de la estructura, ya que estos mutantes no presentan filamentos subpolares. Por lo tanto, esta señal sería independiente de la que genera el aumento de torque, como ocurre en Vibrio, y podría tratarse de una señalización cruzada entre las cascadas de síntesis de ambos sistemas flagelares. Este mismo efecto fue comprobado sobre el mutante estructural en las cuatro flagelinas subpolares (FliC1234), donde también se encontraron aumentadas las flagelinas laterales (LafA12), al igual que los niveles de transcripto de su regulador maestro (lafR). De esta manera, proponemos que la menor movilidad producto de la ausencia del flagelo subpolar podría compensarse parcialmente con un aumento de la expresión del sistema flagelar lateral. Ello podría dar como resultado un aumento en el número de estos flagelos y/o un aumento en la longitud de los mismos.

Sin embargo, el mutante en $\mathrm{FlaF}_{\mathrm{s}}$, que tampoco es capaz de sintetizar el flagelo subpolar, mostró niveles iguales de transcripto de lafR comparado con la cepa WT. Este fenotipo parecería revertirse cuando se muta el regulador $\mathrm{FlbT}_{S}$ sobre la cepa carente de $\mathrm{FlaF}_{s}$, que tampoco es capaz de sintetizar flagelo subpolar, pero aumenta su capacidad de natación en agar semisólidos, haciendo sospechar que esta recuperación se debe a la expresión del sistema flagelar lateral. Sin embargo, aún no hemos podido cuantificar los niveles de transcripto de lafR en este mutante para confirmar esta hipótesis. Por lo tanto, parecería haber varios niveles de regulación cruzada entre el sistema flagelar subpolar y lateral.

Además, esta regulación cruzada entre ambos sistemas flagelares parecería ser unidireccional, ya que los reguladores del sistema flagelar lateral parecerían no afectar la síntesis del sistema flagelar subpolar. En otras palabras, encontramos que la ausencia del sistema subpolar podría inducir el sistema lateral y no al revés.

\section{Relación entre la regulación de la síntesis del flagelo subpolar y la producción de EPS}

La síntesis del flagelo y la capacidad de movimiento que genera están asociados a un estilo de vida planctónico. La transición al estado de biofilm requiere la coordinación 
de la regulación de varios procesos entre los cuales podemos destacar el apagado del movimiento mediante flagelos, y la inducción de la producción de adhesinas y sustancias requeridas para la síntesis de la matriz del biofilm. Ciertas bacterias son capaces de producir diversos exopolisacáridos (EPS) que les otorgan diferentes propiedades (algunos son neutros como la celulosa, o poseen carga como el alginato o el pel). La celulosa por ejemplo, es útil para la formación de biofilms. Si bien en ensayos in vitro en $R$. leguminosarum la celulosa no contribuye a la adhesión al vidrio, sí lo hace para la formación de biofilms en raíces (Branda et al., 2005; Downie 2010).

La síntesis de EPS en $B$. diazoefficiens se encontró relacionada con genes regulatorios de la cascada de síntesis del flagelo subpolar. Los mutantes en $f l b D$ y flbT mostraron mayor capacidad de producir EPS. Esta conexión entre la síntesis del flagelo subpolar y la síntesis de EPS podría estar mediada por c-di-GMP. Cómo ocurre este fenómeno es una incógnita que queda pendiente para ser investigada.

A continuación y a manera de conclusión final de este trabajo, presentamos un modelo regulatorio para la cascada de síntesis del flagelo subpolar de $B$. diazoefficiens basándonos en datos de la bibliografía y en los resultados obtenidos durante esta Tesis. 


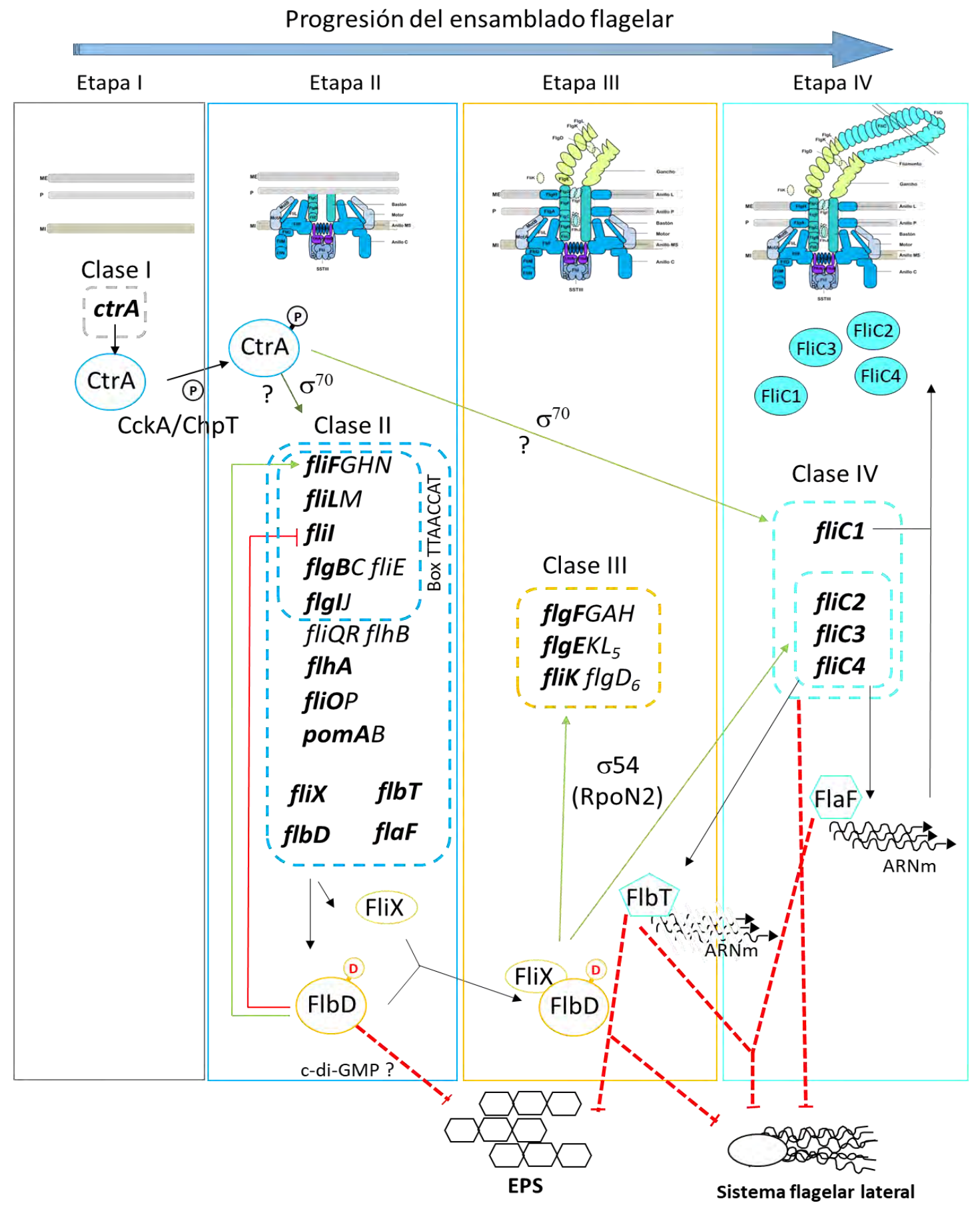

Figura VIII.1 - Modelo regulatorio de la síntesis del flagelo subpolar de $B$. diazoefficiens USDA 110. La flecha azul de arriba indica la progresión temporal de la cascada regulatoria del flagelo subpolar. Los recuadros gris, azul, naranja y celeste representan las cuatro etapas que conformarían la jerarquía transcripcional de la síntesis del flagelo subpolar en $B$. diazoefficiens. Los rectángulos punteados contienen los operones con los genes de clase II, III o IV involucrados en cada etapa. En negrita se encuentran resaltados los genes medidos por qRT-PCR en este trabajo. Las flechas verdes representan regulación positiva, las líneas rojas simbolizan regulación negativa y las flechas negras indican síntesis proteica o transcripción de ARNm. Arriba se esquematiza la estructura flagelar que puede ser ensamblada al finalizar cada una de las etapas regulatorias marcadas en la Figura. Abajo se esquematiza la relación entre la síntesis del flagelo subpolar con la regulación de la síntesis del EPS y la regulación de la síntesis del sistema flagelar lateral (marcado con líneas rojas de puntos dado que no conocemos si la regulación es de manera directa o indirecta). CtrA: regulador de clase I, FlbD y FliX: reguladores de clase II, FlaF y FlbT: reguladores de clase III. Los círculos con una P o D sobre CtrA y FlbD representan la fosforilación (P) o el aminoácido aspártico conservado no fosforilado (D). 


\section{Bibliografía}

Aldridge, P. y U. Jenal (1999). "Cell cycle-dependent degradation of a flagellar motor component requires a novel-type response regulator." Mol Microbiol 32(2): 379-391.

Althabegoiti, MJ. (2010). "Optimización de Inoculantes para la Agricultura Sustentable en Soja. Rol de los flagelos de Bradyrhizobium japonicum en la competición para la nodulación". Tesis doctoral.

Althabegoiti, M. J., J. M. Covelli, J. Perez-Gimenez, J. I. Quelas, E. J. Mongiardini, M. F. Lopez, S. L. LopezGarcia y A. R. Lodeiro (2011). "Analysis of the role of the two flagella of Bradyrhizobium japonicum in competition for nodulation of soybean." FEMS Microbiol Lett 319(2): 133-139.

Althabegoiti, M. J., S. L. Lopez-Garcia, C. Piccinetti, E. J. Mongiardini, J. Perez-Gimenez, J. I. Quelas, A. Perticari y A. R. Lodeiro (2008). "Strain selection for improvement of Bradyrhizobium japonicum competitiveness for nodulation of soybean." FEMS Microbiol Lett 282(1): 115-123.

Anderson, P. y J. Gober (2000). "FlbT, the post-transcriptional regulator of flagellin synthesis in Caulobacter crescentus, interacts with the 50 untranslated region of flagellin mRNA." Molecular Microbiology 38(1): 41-52.

Angelastro, P. S., O. Sliusarenko y C. Jacobs-Wagner (2010). "Polar localization of the CckA histidine kinase and cell cycle periodicity of the essential master regulator CtrA in Caulobacter crescentus." J Bacteriol 192(2): 539-552.

Ardissone, S. y P. H. Viollier (2015). "Interplay between flagellation and cell cycle control in Caulobacter." Curr Opin Microbiol 28: 83-92.

Arora, S. K., B. W. Ritchings, E. C. Almira, S. Lory y R. Ramphal (1996). "Cloning and characterization of Pseudomonas aeruginosa fliF, necessary for flagellar assembly and bacterial adherence to mucin." Infect Immun 64(6): 2130-2136.

Arora, S. K., B. W. Ritchings, E. C. Almira, S. Lory y R. Ramphal (1998). "The Pseudomonas aeruginosa flagellar cap protein, FliD, is responsible for mucin adhesion." Infect Immun 66(3): 1000-1007.

Baker, A. E. y G. A. O'Toole (2017). "Bacteria, Rev Your Engines: Stator Dynamics Regulate Flagellar Motility." J Bacteriol 199(12).

Ballarre J. (2014). "Estudio de posibles fosfodiesterasas de Bradyrhizobium diazoefficiens relacionadas a la regulación de la movilidad bacteriana". Trabajo final de Licenciatura.

Baraquet, C., K. Murakami, M. R. Parsek y C. S. Harwood (2012). "The FleQ protein from Pseudomonas aeruginosa functions as both a repressor and an activator to control gene expression from the pel operon promoter in response to c-di-GMP." Nucleic Acids Res 40(15): 7207-7218.

Barnett, M. J., D. Y. Hung, A. Reisenauer, L. Shapiro y S. R. Long (2001). "A homolog of the CtrA cell cycle regulator is present and essential in Sinorhizobium meliloti." J Bacteriol 183(10): 3204-3210.

Belas, R. (2014). "Biofilms, flagella, and mechanosensing of surfaces by bacteria." Trends Microbiol 22(9): 517-527.

Benson, A. K., J. Wu y A. Newton (1994). "The role of FlbD in regulation of flagellar gene transcription in Caulobacter crescentus." Res Microbiol 145(5-6): 420-430.

Bhuvaneswari, T. V., B. G. Turgeon y W. D. Bauer (1980). "Early Events in the Infection of Soybean (Glycine max L. Merr) by Rhizobium japonicum: I. LOCALIZATION OF INFECTIBLE ROOT CELLS." Plant Physiol 66(6): 1027-1031.

Blair, K. M., L. Turner, J. T. Winkelman, H. C. Berg y D. B. Kearns (2008). "A molecular clutch disables flagella in the Bacillus subtilis biofilm." Science 320(5883): 1636-1638. 
Boehm, A., M. Kaiser, H. Li, C. Spangler, C. A. Kasper, M. Ackermann, V. Kaever, V. Sourjik, V. Roth y U. Jenal (2010). "Second messenger-mediated adjustment of bacterial swimming velocity." Cell 141(1): 107116.

Branda, S. S., S. Vik, L. Friedman y R. Kolter (2005). "Biofilms: the matrix revisited." Trends Microbiol 13(1): 20-26.

Brilli, M., M. Fondi, R. Fani, A. Mengoni, L. Ferri, M. Bazzicalupo y E. G. Biondi (2010). "The diversity and evolution of cell cycle regulation in alpha-proteobacteria: a comparative genomic analysis." BMC Syst Biol 4: 52.

Calatrava-Morales, N., J. Nogales, K. Ameztoy, B. van Steenbergen y M. J. Soto (2017). "The NtrY/NtrX System of Sinorhizobium meliloti GR4 Regulates Motility, EPS I Production, and Nitrogen Metabolism but Is Dispensable for Symbiotic Nitrogen Fixation." 30(7): 566-577.

Canfield, D. E., A. N. Glazer y P. G. Falkowski (2010). "The evolution and future of Earth's nitrogen cycle." Science 330(6001): 192-196.

Castro, M., S. M. Deane, L. Ruiz, D. E. Rawlings y N. Guiliani (2015). "Diguanylate cyclase null mutant reveals that C-Di-GMP pathway regulates the motility and adherence of the extremophile bacterium Acidithiobacillus caldus." PLoS One 10(2): e0116399.

Claret, L. y C. Hughes (2000). "Functions of the subunits in the $\mathrm{FlhD}(2) \mathrm{C}(2)$ transcriptional master regulator of bacterial flagellum biogenesis and swarming." J Mol Biol 303(4): 467-478.

Cogo, C., J. Perez-Gimenez, C. B. Rajeswari, M. F. Luna y A. R. Lodeiro (2018). "Induction by Bradyrhizobium diazoefficiens of Different Pathways for Growth in D-mannitol or L-arabinose Leading to Pronounced Differences in CO2 Fixation, $\mathrm{O} 2$ Consumption, and Lateral-Flagellum Production." Front Microbiol 9: 1189.

Cooper, J. E. (2007). "Early interactions between legumes and rhizobia: disclosing complexity in a molecular dialogue." J Appl Microbiol 103(5): 1355-1365.

Covelli, J. M., M. J. Althabegoiti, M. F. Lopez y A. R. Lodeiro (2013). "Swarming motility in Bradyrhizobium japonicum." Res Microbiol 164(2): 136-144.

Cowie, A., J. Cheng, C. D. Sibley, Y. Fong, R. Zaheer, C. L. Patten, R. M. Morton, G. B. Golding y T. M. Finan (2006). "An integrated approach to functional genomics: construction of a novel reporter gene fusion library for Sinorhizobium meliloti." Appl Environ Microbiol 72(11): 7156-7167.

Chaban, B., H. V. Hughes y M. Beeby (2015). "The flagellum in bacterial pathogens: For motility and a whole lot more." Semin Cell Dev Biol 46: 91-103.

Cuklina, J., J. Hahn, M. Imakaev, U. Omasits, K. U. Forstner, N. Ljubimov, M. Goebel, G. Pessi, H. M. Fischer, C. H. Ahrens, M. S. Gelfand and E. Evguenieva-Hackenberg (2016). "Genome-wide transcription start site mapping of Bradyrhizobium japonicum grown free-living or in symbiosis - a rich resource to identify new transcripts, proteins and to study gene regulation." BMC Genomics 17: 302.

Dahlstrom, K. M., K. M. Giglio, A. J. Collins, H. Sondermann y G. A. O'Toole (2015). "Contribution of Physical Interactions to Signaling Specificity between a Diguanylate Cyclase and Its Effector." MBio 6(6): e01978-01915.

Dahlstrom, K. M. y G. A. O'Toole (2017). "A Symphony of Cyclases: Specificity in Diguanylate Cyclase Signaling." Annu Rev Microbiol 71: 179-195.

Dardis C. (2013). "Obtención de un mutante en una posible diguanilato cilcasa de Bradyrhizobium japonicum relacionada con la regulación de la movilidad bacteriana". Trabajo final de Licenciatura.

Dasgupta, N. y R. Ramphal (2001). "Interaction of the antiactivator FleN with the transcriptional activator FleQ regulates flagellar number in Pseudomonas aeruginosa." J Bacteriol 183(22): 6636-6644.

Davis, N. J. y P. H. Viollier (2011). "Probing flagellar promoter occupancy in wild-type and mutant Caulobacter crescentus by chromatin immunoprecipitation." FEMS Microbiol Lett 319(2): 146-152. 
Demaneche, S., L. Philippot, M. M. David, E. Navarro, T. M. Vogel y P. Simonet (2009). "Characterization of denitrification gene clusters of soil bacteria via a metagenomic approach." Appl Environ Microbiol 75(2): 534-537.

Deng, W., N. C. Marshall, J. L. Rowland, J. M. McCoy, L. J. Worrall, A. S. Santos, N. C. J. Strynadka y B. B. Finlay (2017). "Assembly, structure, function and regulation of type III secretion systems." Nat Rev Microbiol 15(6): 323-337.

Dombrecht, B., J. Vanderleyden y J. Michiels (2001). "Stable RK2-derived cloning vectors for the analysis of gene expression and gene function in gram-negative bacteria." Mol Plant Microbe Interact 14(3): 426-430.

Downie, J. A. (2010). "The roles of extracellular proteins, polysaccharides and signals in the interactions of rhizobia with legume roots." FEMS Microbiol Rev 34(2): 150-170.

Faulds-Pain, A., C. Birchall, C. Aldridge, W. D. Smith, G. Grimaldi, S. Nakamura, T. Miyata, J. Gray, G. Li, J. X. Tang, K. Namba, T. Minamino y P. D. Aldridge (2011). "Flagellin redundancy in Caulobacter crescentus and its implications for flagellar filament assembly." J Bacteriol 193(11): 2695-2707.

Ferguson, B. J., A. Indrasumunar, S. Hayashi, M. H. Lin, Y. H. Lin, D. E. Reid y P. M. Gresshoff (2010). "Molecular analysis of legume nodule development and autoregulation." J Integr Plant Biol 52(1): 61-76.

Ferooz, J., J. Lemaire y J. J. Letesson (2011). "Role of FlbT in flagellin production in Brucella melitensis." Microbiology 157(Pt 5): 1253-1262.

Flemming, H. C., J. Wingender, U. Szewzyk, P. Steinberg, S. A. Rice y S. Kjelleberg (2016). "Biofilms: an emergent form of bacterial life." Nat Rev Microbiol 14(9): 563-575.

Francez-Charlot, A., A. Kaczmarczyk y J. A. Vorholt (2015). "The branched CcsA/CckA-ChpT-CtrA phosphorelay of Sphingomonas melonis controls motility and biofilm formation." Mol Microbiol 97(1): 4763.

Gage, D. J. (2004). "Infection and invasion of roots by symbiotic, nitrogen-fixing rhizobia during nodulation of temperate legumes." Microbiol Mol Biol Rev 68(2): 280-300.

Galperin, M. Y., A. N. Nikolskaya y E. V. Koonin (2001). "Novel domains of the prokaryotic two-component signal transduction systems." FEMS Microbiol Lett 203(1): 11-21.

Gao, S., S. B. Romdhane, S. Beullens, V. Kaever, I. Lambrichts, M. Fauvart y J. Michiels (2014). "Genomic analysis of cyclic-di-GMP-related genes in rhizobial type strains and functional analysis in Rhizobium etli." Appl Microbiol Biotechnol 98(10): 4589-4602.

Garrido-Sanz, D., M. Redondo-Nieto, E. Mongiardini, E. Blanco-Romero, D. Durán, J. Quelas, M. Martin, R. Rivilla, A. Lodeiro y M. Althabegoiti (2019). "Phylogenomic Analyses of Bradyrhizobium Reveal Uneven Distribution of the Lateral and Subpolar Flagellar Systems, Which Extends to Rhizobiales." Microorganisms 7(2): 50 .

Gibson, K. E., H. Kobayashi y G. C. Walker (2008). "Molecular determinants of a symbiotic chronic infection." Annu Rev Genet 42: 413-441.

Gode-Potratz, C. J., R. J. Kustusch, P. J. Breheny, D. S. Weiss y L. L. McCarter (2011). "Surface sensing in Vibrio parahaemolyticus triggers a programme of gene expression that promotes colonization and virulence." Mol Microbiol 79(1): 240-263.

Greene, S. E., M. Brilli, E. G. Biondi y A. Komeili (2012). "Analysis of the CtrA pathway in Magnetospirillum reveals an ancestral role in motility in alphaproteobacteria." J Bacteriol 194(11): 2973-2986.

Guttenplan, S. B. y D. B. Kearns (2013). "Regulation of flagellar motility during biofilm formation." $\underline{\text { FEMS }}$ Microbiol Rev 37(6): 849-871.

Ha, D. G. y G. A. O'Toole (2015). "c-di-GMP and its Effects on Biofilm Formation and Dispersion: a Pseudomonas Aeruginosa Review." Microbiol Spectr 3(2): MB-0003-2014.

Halbleib, C. M. y P. W. Ludden (2000). "Regulation of biological nitrogen fixation." J Nutr 130(5): 10811084. 
Hall-Stoodley, L., J. W. Costerton y P. Stoodley (2004). "Bacterial biofilms: from the natural environment to infectious diseases." Nat Rev Microbiol 2(2): 95-108.

Hallez, R., A. F. Bellefontaine, J. J. Letesson y X. De Bolle (2004). "Morphological and functional asymmetry in alpha-proteobacteria." Trends Microbiol 12(8): 361-365.

Harshey, R. M. (2003). "Bacterial motility on a surface: many ways to a common goal." Annu Rev Microbiol 57: 249-273.

Hauser, F., G. Pessi, M. Friberg, C. Weber, N. Rusca, A. Lindemann, H. M. Fischer y H. Hennecke (2007). "Dissection of the Bradyrhizobium japonicum NifA+sigma54 regulon, and identification of a ferredoxin gene (fdxN) for symbiotic nitrogen fixation." Mol Genet Genomics 278(3): 255-271.

Hecht, G. B. y A. Newton (1995). "Identification of a novel response regulator required for the swarmer-tostalked-cell transition in Caulobacter crescentus." J Bacteriol 177(21): 6223-6229.

Helmann, J. D. y M. J. Chamberlin (1988). "Structure and function of bacterial sigma factors." Annu Rev Biochem 57: 839-872.

Hengge, R. (2009). "Principles of c-di-GMP signalling in bacteria." Nat Rev Microbiol 7(4): 263-273.

Hickman, J. W. y C. S. Harwood (2008). "Identification of FleQ from Pseudomonas aeruginosa as a c-diGMP-responsive transcription factor." Mol Microbiol 69(2): 376-389.

Hoben, P., N. Royal, A. Cheung, F. Yamao, K. Biemann y D. Soll (1982). "Escherichia coli glutaminyl-tRNA synthetase. II. Characterization of the glnS gene product." J Biol Chem 257(19): 11644-11650.

Homma, M., Y. Komeda, T. lino y R. M. Macnab (1987). "The flaFIX gene product of Salmonella typhimurium is a flagellar basal body component with a signal peptide for export." J Bacteriol 169(4): 1493-1498.

Horiuchi, J., B. Prithiviraj, H. P. Bais, B. A. Kimball y J. M. Vivanco (2005). "Soil nematodes mediate positive interactions between legume plants and rhizobium bacteria." Planta 222(5): 848-857.

Ikeda, T., S. Yamaguchi y H. Hotani (1993). "Flagellar growth in a filament-less Salmonella fliD mutant supplemented with purified hook-associated protein 2." J Biochem 114(1): 39-44.

Imada, K. (2018). "Bacterial flagellar axial structure and its construction." Biophys Rev 10(2): 559-570.

Ishihama, A. (2018). "Building a complete image of genome regulation in the model organism Escherichia coli." J Gen Appl Microbiol 63(6): 311-324.

Jarrell, K. F. y M. J. McBride (2008). "The surprisingly diverse ways that prokaryotes move." Nat Rev Microbiol 6(6): 466-476.

Jenal, U., A. Reinders y C. Lori (2017). "Cyclic di-GMP: second messenger extraordinaire." Nat Rev Microbiol 15(5): 271-284.

Jimenez-Guerrero, I., S. Acosta-Jurado, P. Del Cerro, P. Navarro-Gomez, F. J. Lopez-Baena, F. J. Ollero, J. M. Vinardell y F. Perez-Montano (2017). "Transcriptomic Studies of the Effect of nod Gene-Inducing Molecules in Rhizobia: Different Weapons, One Purpose." Genes (Basel) 9(1).

Jordan D (1984). The Rhizobiaceae. Bergey's Manual of Systematic Bacteriology, (J.G. Holt y N.R. Kreig, Willians y Wilkins, L pp, ed), p. . 24-43. Willians y Wilkins, London.

Kanbe, M., J. Yagasaki, S. Zehner, M. Gottfert y S. Aizawa (2007). "Characterization of two sets of subpolar flagella in Bradyrhizobium japonicum." J Bacteriol 189(3): 1083-1089.

Kaneko, T., Y. Nakamura, S. Sato, K. Minamisawa, T. Uchiumi, S. Sasamoto, A. Watanabe, K. Idesawa, M. Iriguchi, K. Kawashima, M. Kohara, M. Matsumoto, S. Shimpo, H. Tsuruoka, T. Wada, M. Yamada y S. Tabata (2002). "Complete genomic sequence of nitrogen-fixing symbiotic bacterium Bradyrhizobium japonicum USDA110." DNA Res 9(6): 189-197.

Karlinsey, J. E., S. Tanaka, V. Bettenworth, S. Yamaguchi, W. Boos, S. I. Aizawa y K. T. Hughes (2000). "Completion of the hook-basal body complex of the Salmonella typhimurium flagellum is coupled to FlgM secretion and flic transcription." Mol Microbiol 37(5): 1220-1231. 
Kawagishi, I., M. Imagawa, Y. Imae, L. McCarter y M. Homma (1996). "The sodium-driven polar flagellar motor of marine Vibrio as the mechanosensor that regulates lateral flagellar expression." Mol Microbiol 20(4): 693-699.

Kearns, D. B. (2010). "A field guide to bacterial swarming motility." Nat Rev Microbiol 8(9): 634-644.

Kellogg, C. A., S. W. Ross y S. D. Brooke (2016). "Bacterial community diversity of the deep-sea octocoral Paramuricea placomus." PeerJ 4: e2529.

Kirchner, O. y A. Tauch (2003). "Tools for genetic engineering in the amino acid-producing bacterium Corynebacterium glutamicum." J Biotechnol 104(1-3): 287-299.

Kohlmeier, S., T. H. Smits, R. M. Ford, C. Keel, H. Harms y L. Y. Wick (2005). "Taking the fungal highway: mobilization of pollutant-degrading bacteria by fungi." Environ Sci Technol 39(12): 4640-4646.

Kondorosi, E., P. Mergaert y A. Kereszt (2013). "A paradigm for endosymbiotic life: cell differentiation of Rhizobium bacteria provoked by host plant factors." Annu Rev Microbiol 67: 611-628.

Kovach, M. E., P. H. Elzer, D. S. Hill, G. T. Robertson, M. A. Farris, R. M. Roop, 2nd y K. M. Peterson (1995). "Four new derivatives of the broad-host-range cloning vector pBBR1MCS, carrying different antibioticresistance cassettes." Gene 166(1): 175-176.

Kragh, K. N., J. B. Hutchison, G. Melaugh, C. Rodesney, A. E. Roberts, Y. Irie, P. O. Jensen, S. P. Diggle, R. J. Allen, V. Gordon y T. Bjarnsholt (2016). "Role of Multicellular Aggregates in Biofilm Formation." MBio 7(2): e00237.

Krasteva, P. V., J. C. Fong, N. J. Shikuma, S. Beyhan, M. V. Navarro, F. H. Yildiz y H. Sondermann (2010). "Vibrio cholerae VpsT regulates matrix production and motility by directly sensing cyclic di-GMP." Science 327(5967): 866-868.

Kuhn, M. J., F. K. Schmidt, N. E. Farthing, F. M. Rossmann, B. Helm y L. G. Wilson (2018). "Spatial arrangement of several flagellins within bacterial flagella improves motility in different environments." 9(1): 5369.

Kullik, I., S. Fritsche, H. Knobel, J. Sanjuan, H. Hennecke y H. M. Fischer (1991). "Bradyrhizobium japonicum has two differentially regulated, functional homologs of the sigma 54 gene (rpoN)." J Bacteriol 173(3): 1125-1138.

Kutsukake, K., Y. Ohya y T. lino (1990). "Transcriptional analysis of the flagellar regulon of Salmonella typhimurium." J Bacteriol 172(2): 741-747.

Laemmli, U. K. (1970). "Cleavage of structural proteins during the assembly of the head of bacteriophage T4." Nature 227(5259): 680-685.

Lambert, C., K. J. Evans, R. Till, L. Hobley, M. Capeness, S. Rendulic, S. C. Schuster, S. Aizawa y R. E. Sockett (2006). "Characterizing the flagellar filament and the role of motility in bacterial prey-penetration by Bdellovibrio bacteriovorus." Mol Microbiol 60(2): 274-286.

Lang, A. S. y J. T. Beatty (2002). "A Bacterial Signal Transduction System Controls Genetic Exchange and Motility." Journal of Bacteriology 184(4): 913-918.

Laub, M. T., S. L. Chen, L. Shapiro y H. H. McAdams (2002). "Genes directly controlled by CtrA, a master regulator of the Caulobacter cell cycle." Proc Natl Acad Sci U S A 99(7): 4632-4637.

Laub, M. T., L. Shapiro y H. H. McAdams (2007). "Systems biology of Caulobacter." Annu Rev Genet 41: 429-441.

Limpens, E., R. Mirabella, E. Fedorova, C. Franken, H. Franssen, T. Bisseling y R. Geurts (2005). "Formation of organelle-like N2-fixing symbiosomes in legume root nodules is controlled by DMI2." Proc Natl Acad Sci U S A 102(29): 10375-10380.

Lindenberg, S., G. Klauck, C. Pesavento, E. Klauck y R. Hengge (2013). "The EAL domain protein YciR acts as a trigger enzyme in a c-di-GMP signalling cascade in E. coli biofilm control." Embo j 32(14): 2001-2014.

Liu, R. y H. Ochman (2007). "Stepwise formation of the bacterial flagellar system." Proc Natl Acad Sci U S A 104(17): 7116-7121. 
Lodeiro, A. R. (2015). "[Queries related to the technology of soybean seed inoculation with Bradyrhizobium spp]." Rev Argent Microbiol 47(3): 261-273.

Lodeiro, A. R., S. L. Lopez-Garcia, T. E. Vazquez y G. Favelukes (2000). "Stimulation of adhesiveness, infectivity, and competitiveness for nodulation of Bradyrhizobium japonicum by its pretreatment with soybean seed lectin." FEMS Microbiol Lett 188(2): 177-184.

López-García, S. L., A. Perticari, C. Piccinetti, L. Ventimiglia, N. Arias, J. J. De Battista, M. J. Althabegoiti, E. J. Mongiardini, J. Pérez-Giménez, J. I. Quelas y A. R. Lodeiro (2009). "In-Furrow Inoculation and Selection for Higher Motility Enhances the Efficacy of Nodulation." Agronomy Journal 101(2): 357.

Loureiro M, Kaschuk G, Alberton O y Hungria M (2006) Soybean [Glycine max (L.) Merrill] rhizobial diversity in Brazilian oxisols under various soil, cropping, and inoculation managements. Biology and Fertility of Soils 43(6): 665-674.

Llewellyn, M., R. J. Dutton, J. Easter, D. O'Donnol y J. W. Gober (2005). "The conserved flaF gene has a critical role in coupling flagellin translation and assembly in Caulobacter crescentus." Mol Microbiol 57(4): 1127-1142.

Lloret, L. y E. Martinez-Romero (2005). "[Evolution and phylogeny of rhizobia]." Rev Latinoam Microbiol 47(1-2): 43-60.

Macnab, R. M. (2003). "How bacteria assemble flagella." Annu Rev Microbiol 57: 77-100.

Mangan, E. K., J. Malakooti, A. Caballero, P. Anderson, B. Ely y J. W. Gober (1999). "FlbT couples flagellum assembly to gene expression in Caulobacter crescentus." J Bacteriol 181(19): 6160-6170.

Mann, T. H. y L. Shapiro (2018). "Integration of cell cycle signals by multi-PAS domain kinases." Proc Natl Acad Sci U S A 115(30): E7166-E7173.

Mattick, J. S. (2002). "Type IV pili and twitching motility." Annu Rev Microbiol 56: 289-314.

McCarter, L. L. (2004). "Dual flagellar systems enable motility under different circumstances." J Mol Microbiol Biotechnol 7(1-2): 18-29.

McCarter, L. L. (2006). "Regulation of flagella." Curr Opin Microbiol 9(2): 180-186.

McDermott, T. R. y P. H. Graham (1989). "Bradyrhizobium japonicum Inoculant Mobility, Nodule Occupancy, and Acetylene Reduction in the Soybean Root System." Appl Environ Microbiol 55(10): 24932498.

Mercer, R. G., S. J. Callister, M. S. Lipton, L. Pasa-Tolic, H. Strnad, V. Paces, J. T. Beatty y A. S. Lang (2010). "Loss of the response regulator CtrA causes pleiotropic effects on gene expression but does not affect growth phase regulation in Rhodobacter capsulatus." J Bacteriol 192(11): 2701-2710.

Merino, S., J. G. Shaw y J. M. Tomas (2006). "Bacterial lateral flagella: an inducible flagella system." $\underline{\text { FEMS }}$ Microbiol Lett 263(2): 127-135.

Minamino, T., K. Imada y K. Namba (2008). "Molecular motors of the bacterial flagella." Curr Opin Struct Biol 18(6): 693-701.

Minamino, T. y R. M. Macnab (2000). "Domain structure of Salmonella FlhB, a flagellar export component responsible for substrate specificity switching." J Bacteriol 182(17): 4906-4914.

Moens, S., M. Schloter y J. Vanderleyden (1996). "Expression of the structural gene, laf1, encoding the flagellin of the lateral flagella in Azospirillum brasilense Sp7." J Bacteriol 178(16): 5017-5019.

Mohari, B., M. A. Thompson, J. C. Trinidad, S. Setayeshgar y C. Fuqua (2018). "Multiple Flagellin Proteins Have Distinct and Synergistic Roles in Agrobacterium tumefaciens Motility." 200(23).

Mohr, C. D., J. K. MacKichan y L. Shapiro (1998). "A membrane-associated protein, FliX, is required for an early step in Caulobacter flagellar assembly." J Bacteriol 180(8): 2175-2185.

Mongiardini EJ, Quelas JI, Dardis C, Althabegoiti MJ y L. AR (2017). "Transcriptional Control of the LateralFlagellar Genes of Bradyrhizobium diazoefficiens." J Bacteriol 199:e00253-17. 
Moscoso, J. A., H. Mikkelsen, S. Heeb, P. Williams y A. Filloux (2011). "The Pseudomonas aeruginosa sensor RetS switches type III and type VI secretion via c-di-GMP signalling." Environ Microbiol 13(12): 3128-3138.

Muir, R. E., J. Easter y J. W. Gober (2005). "The trans-acting flagellar regulatory proteins, FliX and FlbD, play a central role in linking flagellar biogenesis and cytokinesis in Caulobacter crescentus." Microbiology 151(Pt 11): 3699-3711.

Muir, R. E. y J. W. Gober (2002). "Mutations in FlbD that relieve the dependency on flagellum assembly alter the temporal and spatial pattern of developmental transcription in Caulobacter crescentus." Mol Microbiol 43(3): 597-615.

Muir, R. E. y J. W. Gober (2004). "Regulation of FlbD activity by flagellum assembly is accomplished through direct interaction with the trans-acting factor, FliX." Mol Microbiol 54(3): 715-730.

Muir, R. E. y J. W. Gober (2005). "Role of integration host factor in the transcriptional activation of flagellar gene expression in Caulobacter crescentus." J Bacteriol 187(3): 949-960.

Mullin, D. A., S. M. Van Way, C. A. Blankenship y A. H. Mullin (1994). "FlbD has a DNA-binding activity near its carboxy terminus that recognizes ftr sequences involved in positive and negative regulation of flagellar gene transcription in Caulobacter crescentus." J Bacteriol 176(19): 5971-5981.

Nambu, T. y K. Kutsukake (2000). "The Salmonella FlgA protein, a putativeve periplasmic chaperone essential for flagellar P ring formation." Microbiology 146 ( Pt 5): 1171-1178.

Newell, P. D., S. Yoshioka, K. L. Hvorecny, R. D. Monds y G. A. O'Toole (2011). "Systematic analysis of diguanylate cyclases that promote biofilm formation by Pseudomonas fluorescens PfO-1." J Bacteriol 193(18): 4685-4698.

Ohnishi, K., K. Kutsukake, H. Suzuki y T. lino (1990). "Gene fliA encodes an alternative sigma factor specific for flagellar operons in Salmonella typhimurium." Mol Gen Genet 221(2): 139-147.

Oldroyd, G. E. y J. A. Downie (2008). "Coordinating nodule morphogenesis with rhizobial infection in legumes." Annu Rev Plant Biol 59: 519-546.

Oldroyd, G. E., J. D. Murray, P. S. Poole y J. A. Downie (2011). "The rules of engagement in the legumerhizobial symbiosis." Annu Rev Genet 45: 119-144.

Ozaki, S., A. Schalch-Moser, L. Zumthor, P. Manfredi, A. Ebbensgaard, T. Schirmer y U. Jenal (2014). "Activation and polar sequestration of PopA, a c-di-GMP effector protein involved in Caulobacter crescentus cell cycle control." Mol Microbiol 94(3): 580-594.

Page, A. L. y C. Parsot (2002). "Chaperones of the type III secretion pathway: jacks of all trades." Mol Microbiol 46(1): 1-11.

Panis, G., S. R. Murray y P. H. Viollier (2015). "Versatility of global transcriptional regulators in alphaProteobacteria: from essential cell cycle control to ancillary functions." FEMS Microbiol Rev 39(1): 120133.

Partridge, J. D., V. Nieto y R. M. Harshey (2015). "A new player at the flagellar motor: FliL controls both motor output and bias." MBio 6(2): e02367.

Patil, G., R. Mian, T. Vuong, V. Pantalone, Q. Song, P. Chen, G. J. Shannon, T. C. Carter y H. T. Nguyen (2017). "Molecular mapping and genomics of soybean seed protein: a review and perspective for the future." Theor Appl Genet 130(10): 1975-1991.

Patriarca, E. J., R. Tate, S. Ferraioli y M. laccarino (2004). "Organogenesis of legume root nodules." Int Rev Cytol 234: 201-262.

Paul, K., V. Nieto, W. C. Carlquist, D. F. Blair yR. M. Harshey (2010). "The c-di-GMP binding protein YcgR controls flagellar motor direction and speed to affect chemotaxis by a "backstop brake" mechanism." Mol Cell 38(1): 128-139.

Paul, R., S. Weiser, N. C. Amiot, C. Chan, T. Schirmer, B. Giese and U. Jenal (2004). "Cell cycle-dependent dynamic localization of a bacterial response regulator with a novel di-guanylate cyclase output domain." Genes Dev 18(6): 715-727. 
Paulick, A., A. Koerdt, J. Lassak, S. Huntley, I. Wilms, F. Narberhaus and K. M. Thormann (2009). "Two different stator systems drive a single polar flagellum in Shewanella oneidensis MR-1." Mol Microbiol 71(4): 836-850.

Perez-Mendoza, D., I. M. Aragon, H. A. Prada-Ramirez, L. Romero-Jimenez, C. Ramos, M. T. Gallegos y J. Sanjuan (2014). "Responses to elevated c-di-GMP levels in mutualistic and pathogenic plant-interacting bacteria." PLoS One 9(3): e91645.

Petersen, E., P. Chaudhuri, C. Gourley, J. Harms y G. Splitter (2011). "Brucella melitensis cyclic di-GMP phosphodiesterase BpdA controls expression of flagellar genes." J Bacteriol 193(20): 5683-5691.

Pini, F., N. J. De Nisco, L. Ferri, J. Penterman, A. Fioravanti, M. Brilli, A. Mengoni, M. Bazzicalupo, P. H. Viollier, G. C. Walker y E. G. Biondi (2015). "Cell Cycle Control by the Master Regulator CtrA in Sinorhizobium meliloti." PLoS Genet 11(5): e1005232.

Popp, C. y T. Ott (2011). "Regulation of signal transduction and bacterial infection during root nodule symbiosis." Curr Opin Plant Biol 14(4): 458-467.

Prell, J. y P. Poole (2006). "Metabolic changes of rhizobia in legume nodules." Trends Microbiol 14(4): 161168.

Pruss, B. M. y P. Matsumura (1997). "Cell cycle regulation of flagellar genes." J Bacteriol 179(17): 56025604.

Pultz, I. S., M. Christen, H. D. Kulasekara, A. Kennard, B. Kulasekara y S. I. Miller (2012). "The response threshold of Salmonella PilZ domain proteins is determined by their binding affinities for c-di-GMP." Mol Microbiol 86(6): 1424-1440.

Quelas, J. I., M. J. Althabegoiti, C. Jimenez-Sanchez, A. A. Melgarejo, V. I. Marconi, E. J. Mongiardini, S. A. Trejo, F. Mengucci, J. J. Ortega-Calvo y A. R. Lodeiro (2016a). "Swimming performance of Bradyrhizobium diazoefficiens is an emergent property of its two flagellar systems." Sci Rep 6: 23841.

Quelas, J. I., S. Mesa, E. J. Mongiardini, D. Jendrossek y A. R. Lodeiro (2016b). "Regulation of Polyhydroxybutyrate Synthesis in the Soil Bacterium Bradyrhizobium diazoefficiens." Appl Environ Microbiol 82(14): 4299-4308.

Quon, K. C., G. T. Marczynski y L. Shapiro (1996). "Cell cycle control by an essential bacterial twocomponent signal transduction protein." Cell 84(1): 83-93.

Quon, K. C., B. Yang, I. J. Domian, L. Shapiro y G. T. Marczynski (1998). "Negative control of bacterial DNA replication by a cell cycle regulatory protein that binds at the chromosome origin." Proc Natl Acad Sci U S A. 95(1): 120-125.

Ramakrishnan, G. y A. Newton (1990). "FlbD of Caulobacter crescentus is a homologue of the NtrC (NRI) protein and activates sigma 54-dependent flagellar gene promoters." Proc Natl Acad Sci U S A 87(6): 23692373.

Ravishankara, A. R., J. S. Daniel y R. W. Portmann (2009). "Nitrous oxide (N2O): the dominant ozonedepleting substance emitted in the 21st century." Science 326(5949): 123-125.

Regensburger, B. y H. Hennecke (1983). "RNA polymerase from Rhizobium japonicum." Arch Microbiol 135(2): 103-109.

Reisinger, S. J., S. Huntwork, P. H. Viollier y K. R. Ryan (2007). "DivL performs critical cell cycle functions in Caulobacter crescentus independent of kinase activity." J Bacteriol 189(22): 8308-8320.

Romero-Jimenez, L., D. Rodriguez-Carbonell, M. T. Gallegos, J. Sanjuan y D. Perez-Mendoza (2015). "MiniTn7 vectors for stable expression of diguanylate cyclase PleD* in Gram-negative bacteria." BMC Microbiol 15: 190.

Sadowsky, M. J., R. E. Tully, P. B. Cregan y H. H. Keyser (1987). "Genetic Diversity in Bradyrhizobium japonicum Serogroup 123 and Its Relation to Genotype-Specific Nodulation of Soybean." Appl Environ Microbiol 53(11): 2624-2630. 
Sadowski, M.J. y P. Graham. (1998). Soil biology of the Rhizobiaceae. H.P. Spaink, A. Kondorosi y P.J.J. Hooykaas (eds.). En: The Rhizobiaceae. Molecular biology of model plant-associated bacteria. Dordrecht: Kluwer Academic Publishers. 155-172.

Saier, M. H., Jr. (2013). "Microcompartments and protein machines in prokaryotes." J Mol Microbiol Biotechnol 23(4-5): 243-269.

Sambrook, J., Fritsch EF y T Maniatis., (ed) (1989). Molecular cloning: a laboratory manual. 3ed. 3ed. New York. New York. EEUU.

Sauer, K. (2003). "The genomics and proteomics of biofilm formation." Genome Biol 4(6): 219.

Schafer, A., A. Tauch, W. Jager, J. Kalinowski, G. Thierbach y A. Puhler (1994). "Small mobilizable multipurpose cloning vectors derived from the Escherichia coli plasmids pK18 and pK19: selection of defined deletions in the chromosome of Corynebacterium glutamicum." Gene 145(1): 69-73.

Schallies, K. B., C. Sadowski, J. Meng, P. Chien y K. E. Gibson (2015). "Sinorhizobium meliloti CtrA Stability Is Regulated in a CbrA-Dependent Manner That Is Influenced by CpdR1." J Bacteriol 197(13): 2139-2149.

Schaper, S., E. Krol, D. Skotnicka, V. Kaever, R. Hilker, L. Sogaard-Andersen y A. Becker (2016). "Cyclic DiGMP Regulates Multiple Cellular Functions in the Symbiotic Alphaproteobacterium Sinorhizobium meliloti." J Bacteriol 198(3): 521-535.

Schaper, S., H. C. L. Yau, E. Krol, D. Skotnicka, T. Heimerl, J. Gray, V. Kaever, L. Sogaard-Andersen, W. Vollmer y A. Becker (2018). "Seven-transmembrane receptor protein RgsP and cell wall-binding protein RgsM promote unipolar growth in Rhizobiales." PLoS Genet 14(8): e1007594.

Schoenlein, P. V. y B. Ely (1989). "Characterization of strains containing mutations in the contiguous flaF, flbT, or flbA-flaG transcription unit and identification of a novel fla phenotype in Caulobacter crescentus." J Bacteriol 171(3): 1554-1561.

Schoenlein, P. V., J. Lui, L. Gallman y B. Ely (1992). "The Caulobacter crescentus flaFG region regulates synthesis and assembly of flagellin proteins encoded by two genetically unlinked gene clusters." $\mathrm{J}$ Bacteriol 174(19): 6046-6053.

Schuhmacher, J. S., K. M. Thormann y G. Bange (2015). "How bacteria maintain location and number of flagella?" FEMS Microbiol Rev 39(6): 812-822.

Simon, R., Priefer, U. y Pühler, A. (1983). A broad host range mobilization system for in vivo genetic engineering: Transposon mutagenesis in gram negative bacteria. Bio/Technology 1,784-791.

Simon, R., J. Quandt y W. Klipp (1989). "New derivatives of transposon Tn5 suitable for mobilization of replicons, generation of operon fusions and induction of genes in gram-negative bacteria." Gene $\mathbf{8 0}(1)$ : 161-169.

Skerker, J. M. y H. C. Berg (2001). "Direct observation of extension and retraction of type IV pili." Proc Natl Acad Sci U S A 98(12): 6901-6904.

Smit, G., S. Swart, B. J. Lugtenberg y J. W. Kijne (1992). "Molecular mechanisms of attachment of Rhizobium bacteria to plant roots." Mol Microbiol 6(20): 2897-2903.

Smith, T. G. y T. R. Hoover (2009). "Chapter 8 Deciphering Bacterial Flagellar Gene Regulatory Networks in the Genomic Era." 67: 257-295.

Spiers, A. J., J. Bohannon, S. M. Gehrig y P. B. Rainey (2003). "Biofilm formation at the air-liquid interface by the Pseudomonas fluorescens SBW25 wrinkly spreader requires an acetylated form of cellulose." Molecular Microbiology 50(1): 15-27.

Srivastava, D., M. L. Hsieh, A. Khataokar, M. B. Neiditch y C. M. Waters (2013). "Cyclic di-GMP inhibits Vibrio cholerae motility by repressing induction of transcription and inducing extracellular polysaccharide production." Mol Microbiol 90(6): 1262-1276.

Starosta, A. L., J. Lassak, K. Jung y D. N. Wilson (2014). "The bacterial translation stress response." FEMS Microbiol Rev 38(6): 1172-1201. 
Stoodley, P., K. Sauer, D. G. Davies y J. W. Costerton (2002). "Biofilms as complex differentiated communities." Annu Rev Microbiol 56: 187-209.

Su, T., S. Liu, K. Wang, K. Chi, D. Zhu, T. Wei, Y. Huang, L. Guo, W. Hu, S. Xu, Z. Lin y L. Gu (2015). "The REC domain mediated dimerization is critical for FleQ from Pseudomonas aeruginosa to function as a c-di-GMP receptor and flagella gene regulator." J Struct Biol 192(1): 1-13.

Suaste-Olmos, F., C. Domenzain, J. C. Mireles-Rodriguez, S. Poggio, A. Osorio, G. Dreyfus y L. Camarena (2010). "The flagellar protein FliL is essential for swimming in Rhodobacter sphaeroides." J Bacteriol 192(23): 6230-6239.

Sudarsan, N., E. R. Lee, Z. Weinberg, R. H. Moy, J. N. Kim, K. H. Link y R. R. Breaker (2008). "Riboswitches in eubacteria sense the second messenger cyclic di-GMP." Science 321(5887): 411-413.

Sukdeo, N. y T. C. Charles (2003). "Application of crossover-PCR-mediated deletion-insertion mutagenesis to analysis of the bdhA-xdhA2-xdhB2 mixed-function operon of Sinorhizobium meliloti." Arch Microbiol 179(4): 301-304.

Tambalo, D. D., D. E. Bustard, K. L. Del Bel, S. F. Koval, M. F. Khan y M. F. Hynes (2010). "Characterization and functional analysis of seven flagellin genes in Rhizobium leguminosarum bv. viciae. Characterization of R. leguminosarum flagellins." BMC Microbiol 10: 219.

Toutain, C. M., M. E. Zegans y G. A. O'Toole (2005). "Evidence for two flagellar stators and their role in the motility of Pseudomonas aeruginosa." J Bacteriol 187(2): 771-777.

Trampari, E., C. E. Stevenson, R. H. Little, T. Wilhelm, D. M. Lawson and J. G. Malone (2015). "Bacterial rotary export ATPases are allosterically regulated by the nucleotide second messenger cyclic-di-GMP." J Biol Chem 290(40): 24470-24483.

Tuckerman, J. R., G. Gonzalez y M. A. Gilles-Gonzalez (2011). "Cyclic di-GMP activation of polynucleotide phosphorylase signal-dependent RNA processing." J Mol Biol 407(5): 633-639.

Tung, W. L. y K. C. Chow (1995). "A modified medium for efficient electrotransformation of E. coli." Trends Genet 11(4): 128-129.

Turner, L., A. S. Stern y H. C. Berg (2012). "Growth of flagellar filaments of Escherichia coli is independent of filament length." J Bacteriol 194(10): 2437-2442.

Ueda, A. y T. K. Wood (2009). "Connecting quorum sensing, c-di-GMP, pel polysaccharide, and biofilm formation in Pseudomonas aeruginosa through tyrosine phosphatase TpbA (PA3885)." PLoS Pathog 5(6): e1000483.

Van Dellen, K. L., L. Houot y P. I. Watnick (2008). "Genetic analysis of Vibrio cholerae monolayer formation reveals a key role for DeltaPsi in the transition to permanent attachment." J Bacteriol 190(24): 8185-8196.

Vieira, J. y J. Messing (1991). "New pUC-derived cloning vectors with different selectable markers and DNA replication origins." Gene 100: 189-194.

Vincent, J., (1970). A manual for the practical study of the root nodule bacteria. IBP Handbook No 15. Blackwell Scientific Publications, Oxford, UK.

Wilhelms, M., S. Vilches, R. Molero, J. G. Shaw, J. M. Tomas y S. Merino (2009). "Two redundant sodiumdriven stator motor proteins are involved in Aeromonas hydrophila polar flagellum rotation." J Bacteriol 191(7): 2206-2217.

Wu, J., A. K. Benson y A. Newton (1995). "Global regulation of a sigma 54-dependent flagellar gene family in Caulobacter crescentus by the transcriptional activator FlbD." J Bacteriol 177(11): 3241-3250.

Xu, Z., R. J. Dutton y J. W. Gober (2011). "Direct interaction of FliX and FlbD is required for their regulatory activity in Caulobacter crescentus." BMC Microbiol 11: 89.

Zhu, S., A. Kumar, S. Kojima y M. Homma (2015). "FliL associates with the stator to support torque generation of the sodium-driven polar flagellar motor of Vibrio." Mol Microbiol 98(1): 101-110. 



Filamento

Gancho

Bastón

Motor

Anillos

SSTIII FliHIJ

\section{SSTIII FliOPQR}

\section{SSTIII FIhAB}

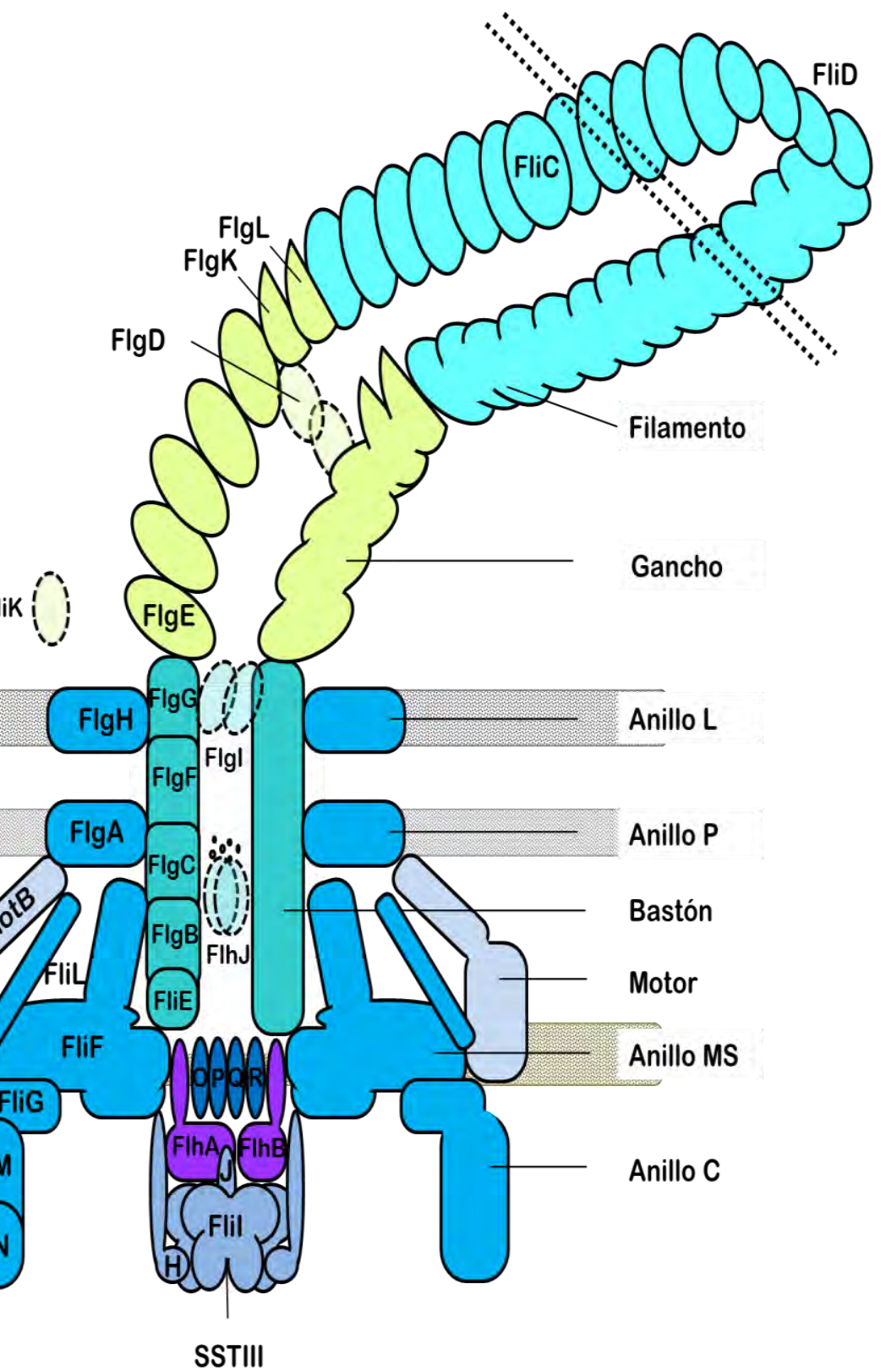

Figura S.1 - Organización estructural de los componentes flagelares. Imagen representativa de todos los componentes estructurales que conforman un flagelo típico. Con los diferentes colores de distinguen las diferentes subestructuras que lo componen. Con transparencias se marcan proteínas que son requeridas durante las diferentes etapas de la síntesis. (Capítulo I.3.2) 


\section{Cluster 1}

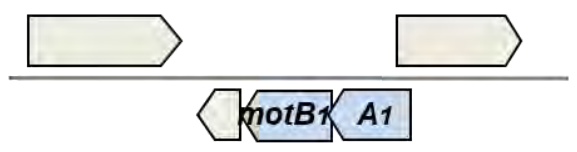

Reguladores

\section{Cluster 2}

SSTIII fliHIJ

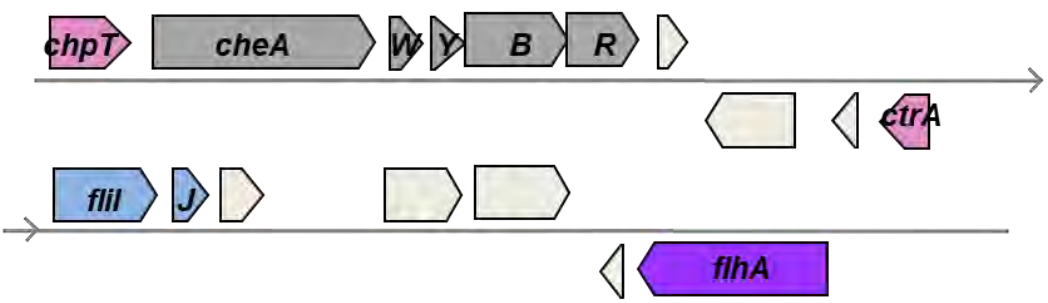

SSTIII fliOPQR

SSTIII fIhAB

Anillos

\section{Cluster 3}

Motor

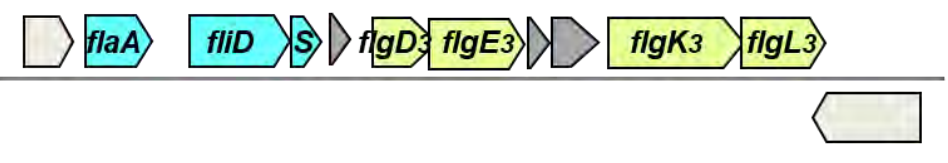

Cluster 4

\section{$\square$ oomA B}

\section{Cluster 5}
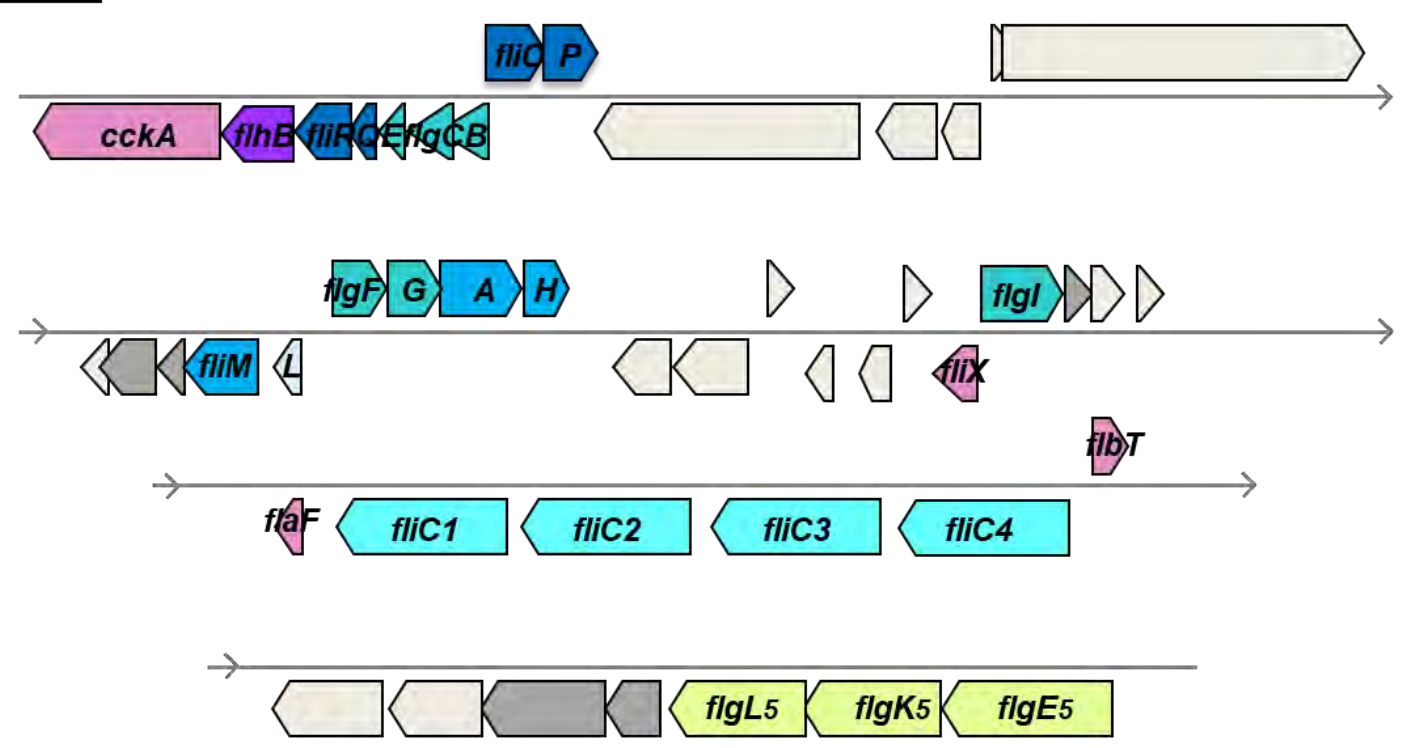

\section{Cluster 6}

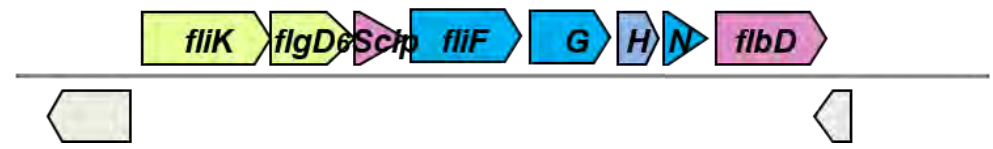

Figura S.2 - Organización genómica de los clusters que contienen genes flagelares estructurales y regulatorios que podrían formar parte del sistema del flagelo subpolar de B. diazoefficiens USDA 110 (Capítulo III.2). 
Tabla S.1 - Listado de genes en los seis clusters que podrían ser parte del sistema del flagelo subpolar de B. diazoefficiens (Capítulo III.2).

\begin{tabular}{|c|c|c|c|c|}
\hline Cluster & Locus_tag & gen & Función propuesta de la proteína & \\
\hline \multirow{2}{*}{1} & bll1510 & $\operatorname{mot} B_{1}$ & Motor & $\mathbf{M}$ \\
\hline & bll1511 & $\operatorname{mot} A_{1}$ & Motor (hipotética) & $\mathbf{M}$ \\
\hline \multirow{10}{*}{2} & blr2191 & chpt & Phosphorelay de CtrA & $\mathbf{R}$ \\
\hline & blr2192 & cheA & Quimiotaxis & $\mathbf{Q}$ \\
\hline & blr2193 & chew & Quimiotaxis & $\mathbf{Q}$ \\
\hline & blr2194 & cher & Quimiotaxis & $\mathbf{Q}$ \\
\hline & blr2195 & cheB & Quimiotaxis & $\mathbf{Q}$ \\
\hline & blr2196 & cher & Quimiotaxis & $\mathbf{Q}$ \\
\hline & blr2200 & ctrA & Regulador de respuesta & $\mathbf{R}$ \\
\hline & blr2201 & flil & ATP-sintasa SSTIII FliHIJ & $\mathbf{S}$ \\
\hline & blr2202 & flis & Proteína de exportación SSTIII FliHIJ & $\mathbf{S}$ \\
\hline & bll2207 & flhA & SSTIII & $\mathbf{S}$ \\
\hline \multirow{10}{*}{3} & blr3695 & flaA & Flagelina & $\mathbf{F}$ \\
\hline & blr3696 & fliD & Cap del filamento & $\mathbf{F}$ \\
\hline & blr3697 & flis & Chaperona flagelina & $\mathbf{F}$ \\
\hline & blr3698 & --- & Proteína hipotética & \\
\hline & blr3699 & $f l g D_{3}$ & Cap del gancho & G \\
\hline & blr3700 & $f l g E_{3}$ & Gancho & G \\
\hline & bsr3701 & --- & Proteína hipotética & \\
\hline & blr3702 & --- & Proteína hipotética & \\
\hline & blr3703 & $\mathrm{flgK}_{3}$ & Unión gancho-filamento & G \\
\hline & blr3704 & $f / g L_{3}$ & Unión gancho-filamento & $\mathbf{G}$ \\
\hline \multirow{2}{*}{4} & blr3800 & pomA & Motor & $\mathbf{M}$ \\
\hline & blr3801 & pomB & Motor & $\mathbf{M}$ \\
\hline \multirow{9}{*}{5} & bll5808 & cckA & Phosphorelay de CtrA & $R$ \\
\hline & bll5809 & $f I h B$ & SSTIII & $\mathbf{s}$ \\
\hline & bll5810 & fliR & SSTIII FliOPQR & $S$ \\
\hline & bll5811 & $f l i Q$ & SSTIII FliOPQR & $\mathbf{S}$ \\
\hline & bll5812 & fliE & Bastón proximal & B \\
\hline & bll5813 & $f \lg C$ & Bastón proximal & B \\
\hline & bll5814 & $f l g B$ & Bastón proximal & B \\
\hline & blr5815 & flio & SSTIII FliOPQR & $S$ \\
\hline & blr5816 & fliP & SSTIII FliOPQR & S \\
\hline
\end{tabular}




\begin{tabular}{|c|c|c|c|c|}
\hline & bll5822 & & Proteína hipotética & \\
\hline & bll5823 & motE & Posible chaperona & \\
\hline & bll5824 & & Proteína hipotética & \\
\hline & bll5825 & flim & Switch Anillo C & A \\
\hline & bll5826 & fliL & Motor & M \\
\hline & blr5827 & $f l g F$ & Bastón proximal & B \\
\hline & blr5828 & $f l g G$ & Bastón distal & B \\
\hline & blr5829 & $f \lg A$ & Anillo P & A \\
\hline & blr5830 & $\mathrm{flgH}$ & Anillo L & A \\
\hline & bll5837 & flix & Regulador & $\mathbf{R}$ \\
\hline & blr5838 & $f l g l$ & Cap del bastón & B \\
\hline & blr5839 & flgJ & Hidrolasa del peptidoglicano & B \\
\hline & bll5842 & flaFs & Regulador & $\mathbf{R}$ \\
\hline & bll5843 & flic1 & Flagelina & $\mathbf{F}$ \\
\hline & bll5844 & flic2 & Flagelina & $\mathbf{F}$ \\
\hline & bll5845 & flic3 & Flagelina & $\mathbf{F}$ \\
\hline & bll5846 & flic4 & Flagelina & $\mathbf{F}$ \\
\hline & blr5847 & $f l b T s$ & Regulador & $\mathbf{R}$ \\
\hline & bll5852 & $f l g L_{5}$ & Unión gancho-filamento & G \\
\hline & bll5853 & $f_{l g} K_{5}$ & Unión gancho-filamento & G \\
\hline & bll5854 & $f l g E_{5}$ & Gancho & $\mathbf{G}$ \\
\hline \multirow{8}{*}{6} & blr6996 & flik & Control gancho & G \\
\hline & blr6997 & $f l g D_{6}$ & Cap del gancho & G \\
\hline & blr6998 & sciP & Regulador de CtrA & $\mathbf{R}$ \\
\hline & blr6999 & fliF & Rotor Anillo MS & A \\
\hline & blr7000 & fliG & Anillo C & A \\
\hline & blr7001 & fliH & SSTIII FliHIJ & $\mathbf{S}$ \\
\hline & blr7002 & fliN & Anillo C & A \\
\hline & blr7003 & $f l b D$ & Regulador & $\mathbf{R}$ \\
\hline
\end{tabular}

